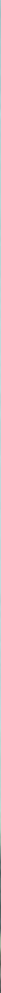

-Ge conservalon Conservação / Conservation

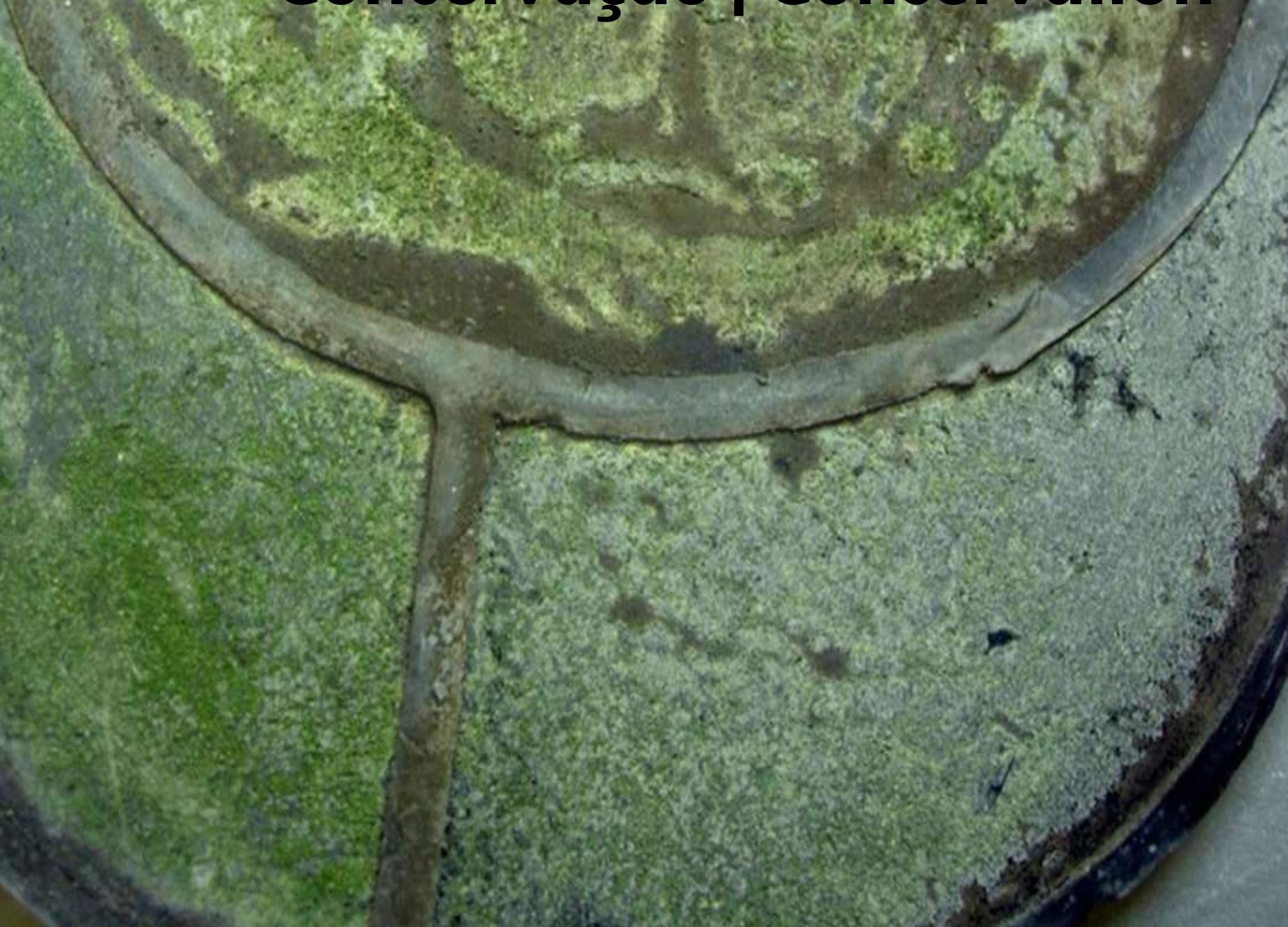

ก๊ก 2013 
Dirección Editorial:

Consejo de Redacción:

Secretario de Edición:

Revisores en esta edición:

Webmaster GEIIC:

Dieño página web:

Maquetación

Traducción:

Foto portada:

ISSN: 1989-8568
Rocío Bruquetas Galán y Ana Calvo Manuel

María Aguiar, Emma García Alonso, Marisa Gómez González, Ana Laborde Marqueze, Emilio Ruiz de Arcaute Martinez, Margarita San Andrés Moya

Christhiam Fiorentino Vásquez

María José Alonso López, Isabel Argerich Fernández, Maite Barrio Olano, Emilio Cano Díaz, Ana Carrasson-López de Letona, Ángel Luis de Sousa Seibane, Soledad Díaz Martinez, Isabel García Fernández, Silvia García Fernández-Villa, Jorge García GómezTejedor, Margarita González Pascual, Diana Lafuente Fernández, María Teresa Martínez López, William Mourey, Anna Nualart Torroja, Diana Pardo San Gil, Carmen Rallo Gruss, Jorge Rivas López, Andrés Sanchéz-Ledesma, Sonia Santos Gómez, Gabriela Siracusano

Emma García Alonso

Pepe Nieto PEZRED

Christhiam Fiorentino Vásquez

María Aguiar

OFernando Cortés Pizano. Fragmento de vidriera contaminado con hongos. Cartuja de Miraflores (Burgos).

Está publicación utiliza una licencia Creative Commons

Se permite compartir, copiar, distribuir y comunicar públicamente la obra con el reconocimiento expreso de su autoría y procedencia. No se permite un uso comercial de la obra original ni la generación de obras derivadas.

Esta revista utiliza Open Journal Systems, software libre de gestión y publicación de revistas desarrollado, soportado y libremente distribuido por el Public Knowledge Project bajo Licencia Pública General GNU.

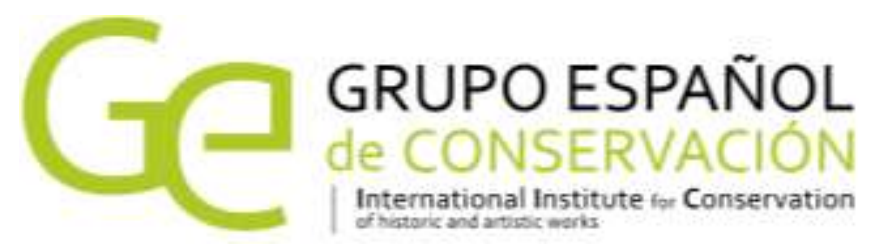

Ge-conservación no se responsabiliza de la información contenida en los artículos ni se identifica necesariamente con ellas.

(C) La propiedad intelectual de los artículos pertenece a los autores y los derechos de edición y publicación de este número son de Ge-conservación. Rogamos que en la difusión libre de los contenidos queden patentes los créditos de los autores y la procedencia.

El Grupo Espańol de Conservación es una asociación independiente afiliada a The International Institute for Conservation of Historic and Artistic Works, inscrita en el Registro Nacional de Asociaciones, Sección 1a, No 160.299. Sede: I.P.C.E. C/Greco, 428040 Madrid. Asociación Declarada de Utilidad Pública por Orden del Ministerio del Interior 3404/2009 (BOE 18-12-2009).

\section{Ge-conservación}

\author{
www.revista.ge-iic.com \\ E-mail: revista@ge-iic.org \\ www.ge-iic.com \\ E-mail: administracion@ge-iic.org
}

Revista indexada en:
Universidad

Complutense Madrid
Biblioteca Complutense

Catálogo Cisne UCM 


\section{Editorial}

En esta ocasión presentamos, por primera vez, la versión semestral de la revista Geconservación, conservação, conservation. Esta nueva propuesta surge a partir de la cantidad y calidad de artículos que se reciben en la redacción, como una forma de agilizar su difusión, y de crear un mayor contacto con los lectores a lo largo del año. La idea inicial era aligerar el número de artículos que aparecían en un solo volumen anual, y distribuirlos, a medida que eran aprobados, en dos números repartidos durante el año. Sin embargo, hemos de decir que, aunque en parte se ha cumplido ese objetivo, el número de artículos no es mucho menor, dada la llegada continua de interesantes colaboraciones. En cualquier caso, se ha pretendido mantener la estructura inicial con algún artículo invitado, una entrevista, y algunas reseñas bibliográficas. Esperamos así, que esta nueva periodicidad, contribuya a una mejor divulgación de los conocimientos en el campo de la conservación de los bienes culturales.

En la sección de firmas invitadas contamos esta vez con María Antonia Moreno Cifuentes, restauradora del Museo Arqueológico Nacional de Madrid, en cuyo artículo "Aspectos sociales de la conservación y restauración del patrimonio" nos ofrece una reflexión sobre la importancia de la sociedad para valorar las actividades de conservación. En la entrevista hemos contado con la entusiasta colaboración de uno de los miembros de la Casa Macarrón, Ángel Macarrón, que, con sus lúcidos 92 años, nos ha relatado en primera persona los avatares de su vida profesional a lo largo del siglo XX.

En relación a los artículos sometidos a revisión anónima por pares presentamos en este número temas de contenido variado, como lo es el propio Patrimonio Cultural. Aspectos históricos relacionados con la conservación y restauración en el siglo XIX en la Catedral de Sevilla, de Ana Galán; intervención y seguimiento de una escultura de bronce de arte público en Montevideo, de Claudia Frigerio y
Pela primeira vez, nesta ocasião, apresentamos a versão semestral da revista GE-conservación, conservação, conservation. Esta nova proposta surge pela quantidade e qualidade dos artigos recebidos na redacção, como uma forma de agilizar a sua difusão e para criar um maior contacto com os leitores, ao longo do ano. A ideia inicial era aliviar o número de artigos que aparecia num único volume anual e distribuilos, à medida que fossem aprovados, em dois números repartidos durante o ano. No entanto, devemos dizer que, embora se tenha cumprido, em parte, esse objectivo, o número de artigos não é muito menor, dada a contínua chegada de colaborações interessantes. Em qualquer dos casos, pretendeu-se manter a estrutura inicial com algum artigo convidado, uma entrevista e com revisões bibliográficas. Esperamos assim, que esta nova periodicidade contribua para uma melhor divulgação do conhecimento na área de conservação dos bens culturais.

Nesta ocasião contamos com o artigo convidado de María Antonia Moreno Cifuentes, "Aspectos sociais da conservação e restauro do património", que reflecte a importância da sociedade para valorizar as actvidades de conservação. Para a entrevista, podemos contar com a entusiástica colaboração de um dos membros da casa Macarrón, Ángel Macarrón, que com os seus lúcidos 92 anos, nos relatou, em primeira pessoa, as mudanças da sua vida profissional, ao longo do século XX.

Relativamente aos artigos submetidos a revisão anónima por pares, apresentamos, neste número, temas de conteúdo variado, como o é, o próprio Património Cultural. Aspectos históricos relacionados com a conservação e restauro do século XIX na catedral de Sevilha, de Ana Galán; intervenção e seguimento de uma escultura em bronze de arte pública em Montevideu, de Manuel Ángel Iglesias e Claudia Frigerío; igualmente relacionado com a importância das operações de manutenção, neste caso, dos vitrais, o artigo de Fernando 
Manuel Ángel Iglesias; también relacionado con la importancia de las tareas de mantenimiento en este caso en las vidrieras, el artículo de Fernando Cortés Pizano; sobre aspectos museológicos y museográficos, los artículos de María Fernando Gomes y Eduarda Vieira en portugués, y el de Susana Solís; de aspectos de arte contemporáneo sobre el problema específico del Eat Art, el artículo de Lorenzo Hortal. De aspectos más técnicos son el de Sonia Tortajada y Manuel María Blanco sobre la limpieza de superficies de escayola con agaragar; y las nuevas tecnologías aplicadas en el proyecto Arqueoláser, de Joaquín Barrio.

Finalmente se presentan algunas reseñas de novedades bibliográficas que nos han parecido de interés en nuestro ámbito.

También nos gustaría informar de que cada día son más las bases de datos en que se encuentra nuestra revista referenciada, así como mayor el interés por la misma en los círculos profesionales y científicos.

Esperamos que este esfuerzo editorial encuentre una buena acogida entre nuestros socios y lectores.
Cortés Pizano; sobre aspectos museológicos e museográficos, os artigos de Maria Fernando Gomes e Eduarda Vieira, em português e o de Susana Solis; de aspectos de arte contemporânea sobre o problema especifico de Eat Art, artigo de Lorenzo Hortal. Sobre aspectos mais técnicos, temos o de Sonia Tortajada e Manuel María Blanco, com a limpeza de superfícies de gesso com agar-agar; os estudos geométricos e construtivos de uma adega de Juan Guas, de Rocío Maira Vidal; e as novas tecnologias aplicadas no projecto Arqueoloaser, de Joaquin Barrio.

Por último, são apresentadas algumas revisões de novidades bibliográficas que nos pareceram de interesse para o nosso âmbito.

Gostaríamos, igualmente, de informar que são, cada vez mais, aas bases de dados em que a nossa revista se encontra referenciada, assim como é maior interesse, pela mesma, nos círculos profissionais e científicos.

Esperamos que este esforço editorial encontre um bom acolhimento entre os nossos sócios e leitores

Ana Calvo y Rocío Bruquetas

Directoras de Ge-conservación 


\section{Índice}

Firma invitada y entrevista

Páginas

Aspectos sociales de la conservación y restauración del patrimonio

María Antonia Moreno Cifuentes

Entrevista con Ángel Macarrón, una vida al servicio del arte

Por Rocío Bruquetas Galán y Ana Calvo Manuel

Artículos

Nuevas aportaciones a la conservación y restauración decimonónica en la Catedral de Sevilla

Ana Galán Pérez

El monumento al General José Gervasio Artigas: la conservación-restauración de escultura conmemorativa en bronce en ambiente urbano

Claudia Frigerio Vidal, Manuel Angel Iglesias Campos

As reservas visíveis do Schaulager, em Basileia

Maria Fernando Gomes, Eduarda Vieira

Sobre la importancia de las tareas de mantenimiento en las vidrieras

Fernando Cortés Pizano

Comida en el arte contemporáno. Restauración, conservación y reactivación del Eat Art

Lorenzo Hortal Valverde

Cleaning plaster surfaces with agar-agar gels: evaluation of the technique

Sonia Tortajada Hernando, Manuel María Blanco Domínguez

Reformulando el museo en el contexto actual de crisis

Susana Solís Zara

Principios de conservación en una tecnología de restauración innovadora en el Patrimonio

Arqueológico. Aplicación en el Proyecto ARQUEOLÁSER

Joaquín Barrio Martín

\section{Reseñas de publicaciones}

Recursos plásticos en la escultura policromada aragonesa de la contrarreforma. Olga Cantos Martínez

Por Ana Laborde Marqueze

La técnica de la pintura mural a Catalunya i les fonts artístiques medievals. Rosa M. Gasols Fargas

Por Rocío Bruquetas Galán

PUR Facts. Conservation of Polyurethane Foam in Art and Design. Thea van Osten

Por Margarita San Andrés Moya

Momias. Manual de buenas prácticas para su preservación. Coodinación Científica: Nieves V., María G. Por Ana Calvo

Turquoise in Mexico and North America: Science, Conservation, Culture and Collections. WAA Por Marisa Goméz

Moving Collections. Processes and Consequences. Flytting av samlinger. Prosesser og Konsekvenser Por Emilio Ruiz de Arcaute

El restaurador de obras de arte en España durante los siglos XVIII y XIX. Nacimiento de una profesión. Del restaurador de obras de arte al conservador-restaurador de bienes culturales. La consolidación disciplinar y profesional de la restauración en España (siglos XX-XXI). Teresa Vicente Rabanaque Por Rocío Bruquetas Galán 
Firma Invitada y Entrevista 


\title{
Aspectos sociales de la conservación y restauración del patrimonio
}

\author{
María Antonia Moreno Cifuentes
}

Resumen: La conservación y restauración pueden cumplir una función social con el acercamiento de la cultura a los ciudadanos porque estos cada día están más interesados en conocer detalles sobre la recuperación del Patrimonio Cultural. La educación y formación de la sociedad sobre criterios, métodos y procesos desarrollados en la intervención sobre una obra son importantes para despertar y atraer la atención del público de forma correcta. En países con importantes legados culturales y falta de recursos para su preservación, la función social de la conservación y restauración es fundamental en varios aspectos: para recuperar el patrimonio, ayudar a la población en tareas de formación como conservadores- restauradores y mejorar la situación económica-laboral de muchas comunidades.

Palabras clave: Conservación, restauración, patrimonio cultural, educación, situación laboral, recuperación, economía.

\section{Aspectos sociais da conservação e restauro do património.}

Resumo: A área de conservação e restauro pode cumprir uma função social através da aproximação da cultura junto dos cidadãos porque estes estão, cada vez mais, interessados em conhecer os detalhes sobre a recuperação do património cultural. A educação e a formação da sociedade sobre critérios, métodos e processos desenvolvidos na intervenção sobre uma obra são importantes para despertar e atrair a atenção do público de forma correcta. Em países com importantes legados culturais e falta de recursos para a sua preservação, a função social da conservação e restauro é fundamental em vários aspectos: para recuperar o património, para ajudar os indivíduos na sua formação como conservadores-restauradores e para melhorar a situação económico-laboral de muitas comunidades.

Palavras-chave: Conservação; restauro; património cultural; educação; situação laboral; recuperação; economia

\section{Some social aspects in the conservation and restoration of heritage}

Abstract: The conservation and restoration can accomplish a social function by culture's approach to citizens, because they are more interested every day for details on the preservation of Cultural Heritage. The education and training of society about criteria, methods and processes developed when a masterpiece is restored are important reasons to attract and stimulate public attention through careful documentation. In countries with a large and important cultural heritage but with few resources for preservation, the social function of the conservation and restoration is essential in several ways: to recover the historical heritage, to help people in their education as conservators-restorers and to improve the economic and employment situation in many communities.

Keywords: Conservation, restoration, cultural heritage, education, employment status, recovery, economy.

La sociedad solicita actualmente acceso a la cultura de forma constante, por lo que es un deber y obligación de los poderes políticos, económicos, sociales y culturales ofertar y procurar el acceso de los ciudadanos a esta demanda. Las opciones que se ofrecen van desde conciertos, teatro, exposiciones temporales, museos, etc., hasta visitas guiadas a monumentos, yacimientos arqueológicos, centros de interpretación, museos del sitio, paisajes culturales y, las más actuales, rutas culturales combinadas con las gastronómicas. 
En esta amplia gama de posibilidades de acercamiento del ciudadano a la cultura se añade, desde hace ya varios años, la información acerca de la conservación y restauración del patrimonio y de los bienes culturales. El visitante de un museo, una exposición temporal o un monumento está cada vez más interesado en conocer lo que se esconde detrás del objeto, el cuadro o la iglesia que son objeto de su atención; de ahí que las noticias que pueden aportar los procesos de conservación y restauración de estos son, indudablemente, motivos atractivos y una buena justificación para conocer y divulgar en la sociedad aspectos tan importantes como la protección del patrimonio histórico.

El problema que surge como consecuencia de esta demanda cultural y visitas masivas es la enorme aglomeración que, consecuentemente en el caso de los bienes culturales, supone un riesgo para su integridad y conservación. Establecer un criterio único de actuación es difícil y las opiniones son variadas e, incluso, muy encontradas. Por un lado es importante conservar y restaurar, pero un exceso de visitantes en el caso de ciertos bienes culturales es un peligro físico para su preservación a corto, medio y largo plazo; por otro lado no hay que olvidar que el público genera unos beneficios económicos que bien administrados pueden revertir en la conservación y restauración del patrimonio. Conservar y restaurar comporta costes de dinero que, por ejemplo, en el caso de ayuntamientos pequeños con presupuestos limitados y un rico patrimonio histórico y cultural, conduce a la autofinanciación basada en visitas a zonas arqueológicas, museos y otros lugares de interés en el municipio. Este fenómeno se está convirtiendo en algo muy común y si no se controla debidamente puede crear un conflicto de intereses con resultados nocivos para la preservación de los bienes culturales. Es también el caso del patrimonio de la Iglesia que, en pueblos pequeños, es gestionado directamente por los párrocos y cuyos beneficios económicos se dedican a necesidades más urgentes de tipo social o humanitaria y nada tienen que ver con la conservación.

La buena intención, la falta de formación técnica del personal que interviene una obra, los errores a la hora de plantear una actuación sobre el patrimonio, en ocasiones con la excusa de no tratarse de un objeto declarado Bien de Interés Cultural, o el gasto excesivo que supone la restauración, son motivos que intentan justificar, de cara a la sociedad, unas intervenciones deficientes e inadecuadas y que siempre deberían estar supervisadas y dirigidas por conservadores y restauradores especialistas. Casos como el recientemente ocurrido en la ermita de Borja (Zaragoza) de la destrucción -aunque mal llamada restauración- de una figura de Cristo por parte de una feligresa del pueblo pone de manifiesto, desgraciadamente, la ignorancia general y el largo camino que todavía queda por recorrer para acercar la conservación y restauración del patrimonio a la sociedad, de una forma seria y documentada. Establecer una línea de separación entre el voluntarismo de algunas personas en su afán de conservar y la obligación de enseñar y aprender lo importante que es la formación y profesionalidad de los conservadores-restauradores, junto con la documentación exhaustiva de las intervenciones, es una tarea pendiente que desde la entidades públicas y autoridades culturales deberá ser emprendida, especialmente en lugares en los que las carencias son más notorias.

La falta de sensibilidad y desconocimiento de la restauración de algunos ciudadanos es notoria cuando se trata de actuaciones realizadas sobre imágenes de devoción o culto, especialmente si se trata de procesos de limpieza; es este un tema delicado que crea debates en la sociedad, cuando tras una restauración aparecen notables cambios morfológicos y físicos en esculturas religiosas queridas y respetadas por sus devotos, que siempre las han conocido con un aspecto muy determinado y tradicional. Para evitar que una restauración en este tipo de obras sea motivo de escándalo social y cree polémicas innecesarias es importante, y una obligación, que los profesionales hagan una exhaustiva documentación y analítica antes de la intervención, se acerquen y expliquen su trabajo a la población y devotos de estas imágenes: los diversos procesos 
de limpieza, la consolidación, reintegración cromática, etc. Todos recordamos la gran discusión e incluso controversia que se estableció cuando se restauró la capilla Sixtina de Miguel Ángel en los años 80. Los resultados tras la limpieza fueron espectaculares y muchos ciudadanos, conocedores de la obra y habituados al color oscuro y la "pátina de Miguel Ángel", e incluso especialistas, criticaron y dudaron de los restauradores porque consideraron que se había perdido cromatismo original a causa de la restauración. La detallada documentación y analítica generada previamente, durante y tras la intervención sirvieron para demostrar que todas las actuaciones estaban justificadas. En el lado opuesto a estas opiniones se encuentran las de aquellos que consideran, por ejemplo en el caso del arte religioso en ciertos países, que una imagen o una obra de culto, que no es solamente una pieza decorativa o algo sólo para el disfrute estético, únicamente tiene un significado especial para la religión pero no como un bien patrimonial, por lo que la forma física no adquiere demasiado importancia; este punto de vista influye en el enfoque de la restauración ya que no siempre es fácil convencer a la gente que una intervención total o reconstrucción de una imagen no es una buena solución y de ahí el interés por mostrar las razones y criterios de la conservación y restauración actuales (Agrawal, O. P. 1975). Desconocer un trabajo especializado que no artístico- como es la conservación y crear polémica por esta causa, no puede ser motivo para que una actuación necesaria o la profesionalidad de un técnico sean puestas en entredicho y se acometa una intervención sin las garantías fundamentales y la comprensión de la sociedad.

La educación de los ciudadanos en materia de conservación y restauración es fundamental para comprender la necesidad de preservar el patrimonio. Es importante explicar las razones por las que se custodia, protege y restaura una obra, lo fundamental que es la formación científica y técnica del conservador-restaurador, así como la obligación de respetar unas normas básicas de actuación cuando visitamos monumentos, un museo o cualquier otro bien histórico y cultural. Como un ejemplo puede valer el cartel que acompaña la exposición de un sarcófago policromado, en el Museo de los Claustros de Nueva York, en donde se explican las razones para pedir que no te toque esta obra; la imagen refleja el deterioro que sufre el sarcófago en las partes más cercanas al visitante en contraposición a la mejor conservación que presentan las más alejadas a este [figura 1]. Educar en tareas de vigilancia, conservación preventiva, limpieza diaria, mantenimiento, conocimiento del monumento, etc. son labores fáciles de poner en práctica que ayudan para que guardias, personal de seguridad y de apoyo en el cuidado de monumentos, museos de sitio y otros lugares de interés para el visitante, tengan más protagonismo y se involucren e interesen especialmente por el lugar en el que trabajan.

La demanda para conocer de cerca monumentos y bienes que integran el patrimonio cultural, así como las intervenciones a las que estos se ven sometidos, tiene como parte positiva su divulgación entre el público y es una ocasión única para informar adecuadamente sobre materias compositivas, técnicas de fabricación, técnicas analíticas, procesos de restauración, participantes en el proyecto, modos de financiación, etc. La aglomeración y masificación de las visitas suponen, sin embargo, un grave riesgo para la preservación de los bienes patrimoniales y de todos son conocidas algunas soluciones que han sido necesarias: cierres de cuevas prehistóricas y de tumbas faraónicas, recorridos obligatorios en yacimientos arqueológicos, control en las visitas a museos, etc. Por ello es importante encauzar los beneficios económicos que generan los bienes culturales para que, al menos, una parte de estos se dediquen a programas de mantenimiento, conservación preventiva y restauración. La alternativa que se ofrece a los problemas de conservación derivados del exceso de visitantes en monumentos es la realización de copias que puedan sustituir, parcialmente, el conocimiento y deleite de una obra. En este sentido la réplica de la cueva de Lascaux fue pionera en su momento y ha sido continuada por la de la Sala de Polícromos de Altamira que, actualmente, es tan visitada como si de un museo o cueva original se tratara'. 


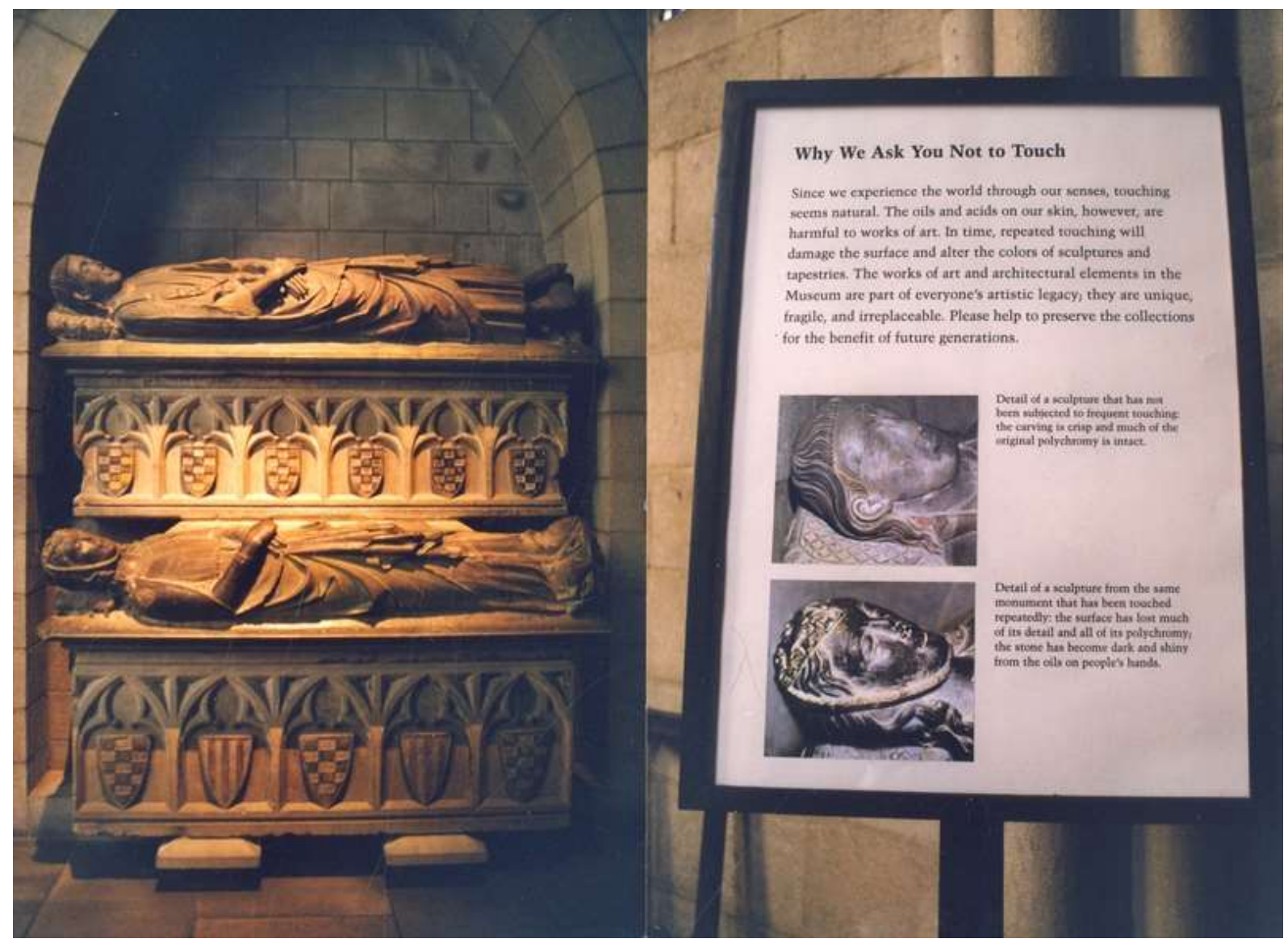

Figura 1. Cartel explicativo sobre los problemas de conservación de un sarcófago policromado. Museo de los Claustros de Nueva York. @M Antonia Moreno Cifuentes.

Las crisis económica y social actuales son un problema para la financiación de nuevos proyectos, sean estos de carácter público o privado, aunque hay que reconocer que, en ciertos casos, los riesgos físicos y el deterioro originados por las visitas masivas e ilimitadas a los monumentos han disminuido y esto se refleja en una mejor inspección de acceso de entrada del público que, de forma más fluida y fácil, puede ser mejor controlado por los guardas. Combinar la conservación de los bienes culturales con la masificación turística es una difícil tarea que, con la ayuda de un buen programa didáctico y divulgativo, puede ser motivo para que la sociedad se acerque al patrimonio y entienda que su preservación es fundamental para el futuro y responsabilidad de todos. En algunos países como Egipto, con un rico patrimonio arqueológico, se ha visto reducido drásticamente el número de visitantes a templos y tumbas con motivo de la revolución de enero de 2011, con preocupantes consecuencias para sufragar el mantenimiento y restauración de sus monumentos debido a la disminución de entrada de divisas que el turismo genera [figuras 2 y 3 ]. En otros países esta crisis económica queda reflejada en el descenso de viajeros extranjeros a los museos y monumentos más importantes, con dos consecuencias contrapuestas: por un lado, reducción de proyectos arqueológicos y de restauración que se financian con las ganancias derivadas del turismo, y por otro, esto también supone menor riesgo de alteración y daños en los monumentos que en los últimos años, antes de la revolución en el caso de países árabes, estaban en peligro a causa de la entrada masiva de público. 

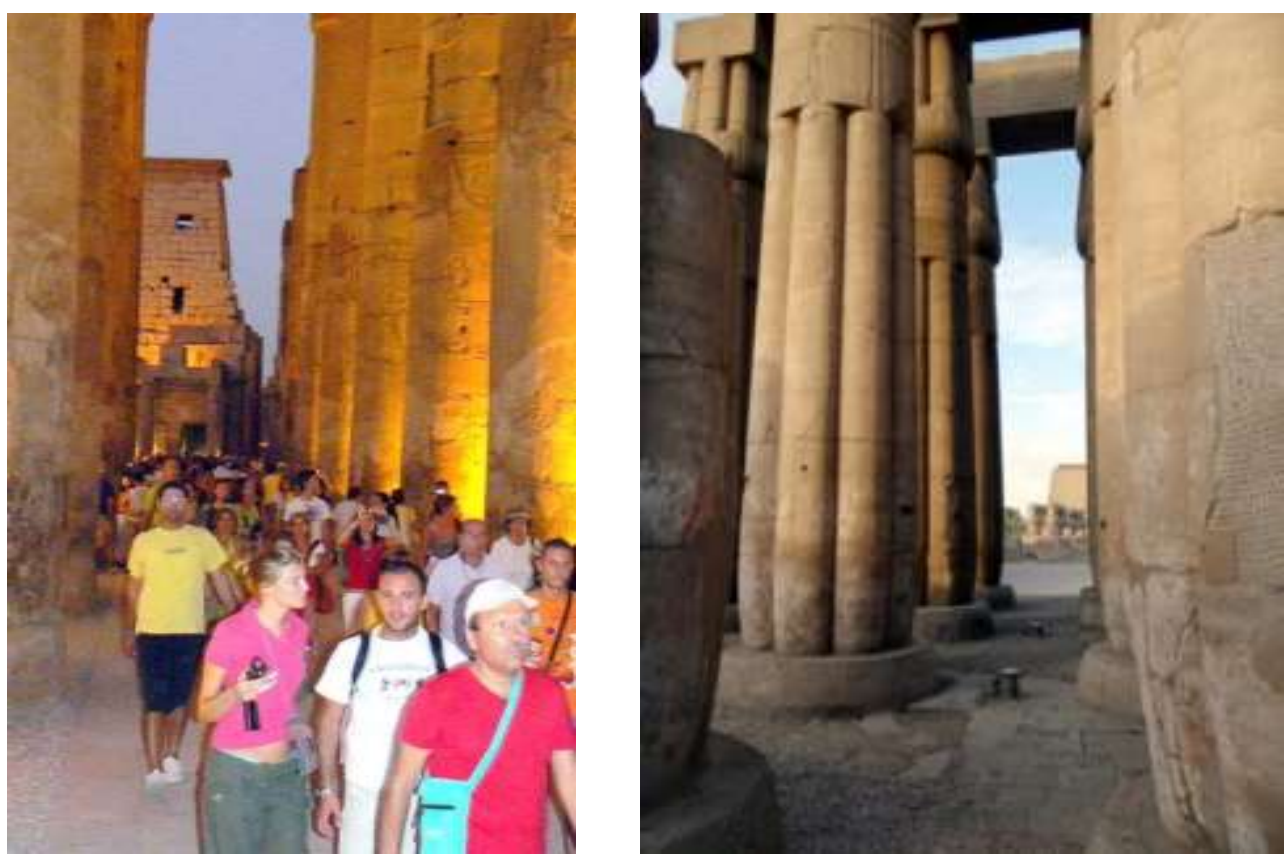

Figuras 2 y 3. Grupos de turistas visitando el templo de Amón en Luxor: octubre de 2008. La misma zona del templo de Amón en Luxor: febrero 2013. OMª Antonia Moreno Cifuentes.

Acercar la conservación y restauración a los ciudadanos es una tarea que muchas instituciones, especialmente museos, programan entre sus actividades desde hace ya varios años. Aprovechando el potencial divulgativo que suponen las redes sociales e Internet, a través de sus páginas web, se están difundiendo los trabajos de remodelación de los edificios ${ }^{2}$, junto con los de conservación y restauración de las colecciones que se realizan en los laboratorios de restauración. Actualmente también es normal encontrar información bien documentada que acompaña a obras recién restauradas y que interesan enormemente al visitante porque, junto al conocimiento y deleite de una obra expuesta, podemos entender la situación y circunstancias que le han acontecido antes de ser mostrada en público; datos como los procesos analíticos, tratamientos de limpieza y reintegración, los cambios físicos, morfológicos o estéticos de un objeto, son aspectos de los bienes culturales que interesan a un gran número de personas que visitan los museos y otros bienes patrimoniales. En este tipo de exposiciones es importante dar una información didácticamente comprensible, sin emplear un lenguaje en exceso técnico, sofisticado o difícil de entender para un espectador ajeno a los pormenores de la conservación, pero siempre con la precisión y documentación que cada obra requiere [figura 4]. Como ejemplo de ello, la exposición que se llevó a cabo en el Museo del Prado sobre la restauración del Adán y Eva de Albert Durero en 2010 y 2011, con paneles explicativos de análisis con luz infrarroja y ultravioleta, así como del proceso de restauración del soporte y la capa pictórica, tuvo una gran acogida por parte de los visitantes que entendieron las razones y desarrollo en la intervención de esta tabla ${ }^{3}$.

Esta labor social y de educación de la restauración, difundida especialmente en instituciones museísticas y centros de interpretación sobre monumentos, suele comenzar en los departamentos didácticos que organizan talleres para niños, personal generalmente muy receptivo a experiencias prácticas y actividades variadas que realizan estos organismos; desde hace años, muchos museos coordinan con escuelas y colegios diferentes talleres en los que se incluyen los laboratorios de restauración, donde el público infantil se acerca a los objetos, conoce directamente los problemas 
para su conservación y puede ser instruido sobre la importancia del patrimonio. Estos ejercicios, muy extendidos en la actualidad, tienen que resultar atractivos para el niño y estar bien orientados, con una selección por edades y un perfil infantil concreto, las prácticas deben ser realizadas siempre con reproducciones de piezas del museo, un determinado tipo de materiales, etc. (González y Moreno 1991:33). En esta misma línea de actuación se incluyen las visitas organizadas a los laboratorios de restauración que, en jornadas de puertas abiertas o en recorridos especiales, se realizan cada 18 de mayo - Día Internacional de los Museos -, celebrado y auspiciado por el Consejo Internacional de Museos (ICOM) ${ }^{4}$.

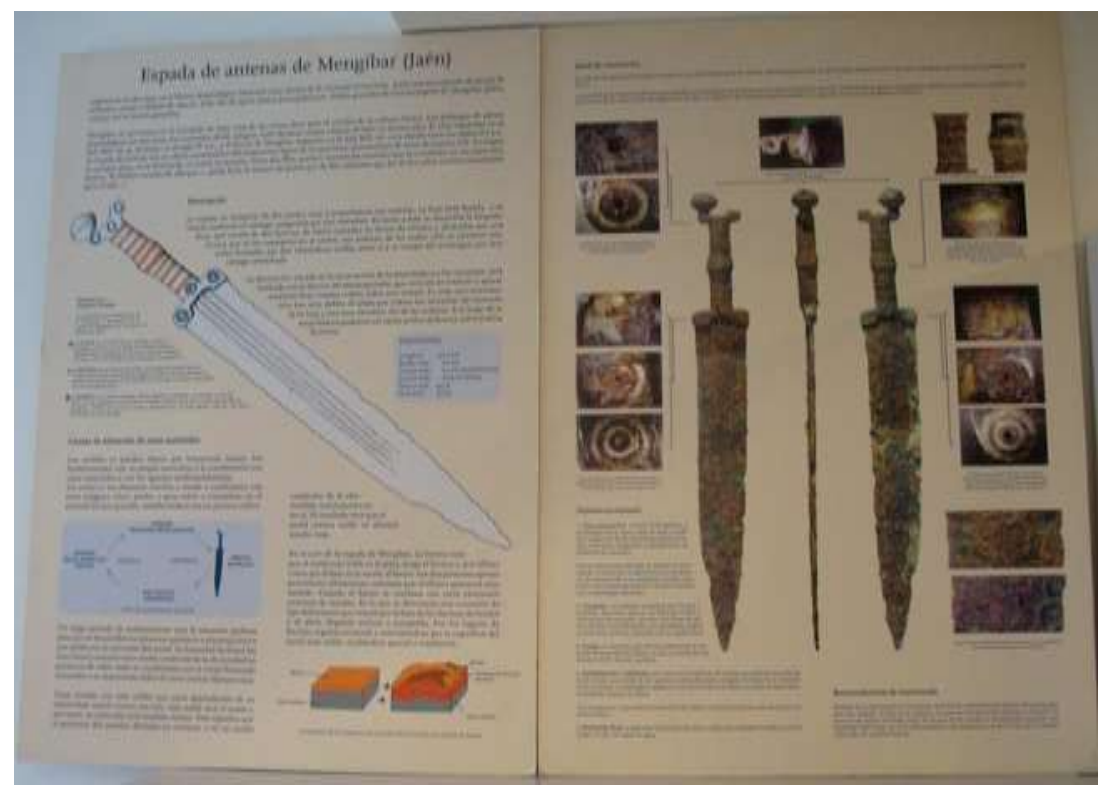

Figura 4. Cartel sobre la restauración de la espada de antenas de Mengíbar (Jaén) que se llevó a cabo hace unos años en el Museo Arqueológico Nacional. $\mathrm{CM}^{\mathrm{a}}$ Antonia Moreno Cifuentes.

El protagonismo que la conservación y restauración va adquiriendo en la sociedad actual se refleja en algunos museos históricos que muestran al visitante parte de su pasado e historiografía a través de antiguos montajes e intervenciones de restauración. La nueva museografía incluye en su exposición recorridos para conocer las circunstancias y trayectoria que ha sufrido el edificio, manteniendo antiguas actuaciones o indicios de desastres que han afectado al edificio y sus colecciones. Una correcta y documentada explicación sobre estos aspectos son muy atractivos para el ciudadano que comprende no solamente las piezas y su antigüedad, sino también otras actividades que se han desarrollado en los museos, en muchos casos, desde su creación. Ejemplos de estas actuaciones pueden ser el Ashmolean Museum en Oxford y el Neues Museum en Berlín que tras su remodelación ha mantenido las partes afectadas por los bombardeos de la Segunda Guerra Mundial y muestra en una sala -la denominada y muy visitada Red Room- piezas con viejas restauraciones y montajes que son historia de la museografía más reciente [figura 5].

Otra de las actividades que cobra más fuerza día a día es la posibilidad de conocer directamente los procesos de restauración, en tiempo real, realizados por los propios restauradores que trabajan en una obra; esta oportunidad se encuadra dentro de las funciones divulgativas de un museo o un monumento en el transcurso de su restauración y rehabilitación, siempre desde una perspectiva didáctica y como acercamiento e instrucción de este tipo de trabajos al ciudadano. Un ejemplo reciente de estas actuaciones es la que se ha llevado a cabo con el cuadro El Paraíso de Tintoretto 
que se conserva en el Museo Thyssen de Madrid; en la visita a la "restauración en directo" - a través de un panel colocado en la propia sala de exposición se ve el trabajo de los técnicos sobre la pintura- , se puede completar con la información que ofrece la página web del centro, en la que se explica uno de los objetivos del proyecto: "...involucrar a los visitantes en todo este proceso" y también se detallan, para las personas que estén interesados en conocer más acerca de estas intervenciones, los procesos de análisis, estudios previos a los tratamientos, historia del cuadro, instituciones colaboradoras, etc. 5 .

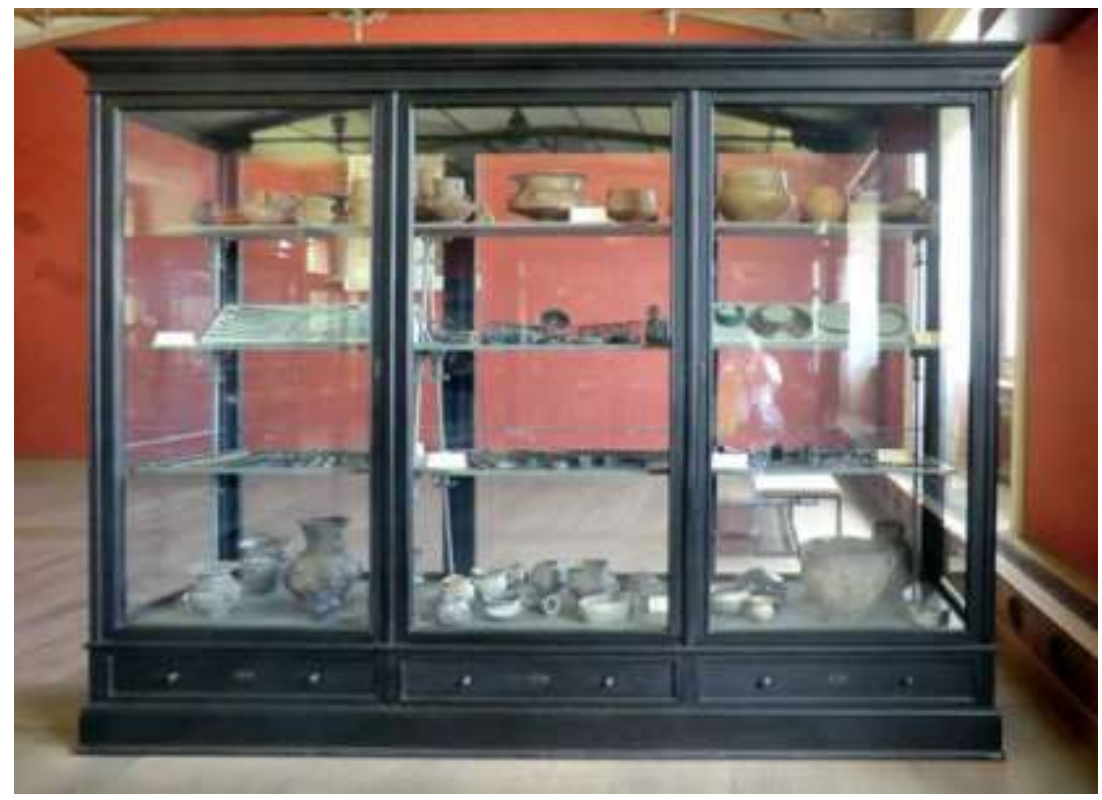

Figura 5. La Red Room en donde se muestran montajes y restauraciones antiguas. Neues Museum, Berlín. $\bigcirc \mathrm{M}^{\mathrm{a}}$ Antonia Moreno Cifuentes.

En la misma línea de actuación se encuadra el proyecto que se lleva a cabo desde hace varios años en la catedral de Vitoria-Gasteiz en el que se incluyen visitas guiadas para conocer las obras de restauración en el templo de Santa María en cuyo plan director se ha programado "....abrir al público el desarrollo material de los trabajos"; en su página web encontramos información detallada sobre las reservas para visitas, un recorrido virtual, el plan director y todos los proyectos de restauración que se llevan a cabo en el edificio ${ }^{6}$. Otras propuestas privadas tratan de acercar al ciudadano a la conservación con el objetivo de recuperar, mediante su colaboración, objetos y bienes culturales que por falta de medios económicos corren peligro de alterarse o pederse; un ejemplo es el caso producido hace unos años en Sittingbourne (Kent. Inglaterra) en donde en 2008 el Canterbury Archaeological Trust excavó un cementerio anglo sajón con una gran cantidad de tumbas y objetos de metal, huesos, vidrio, etc. Debido a la falta de medios y los problemas de conservación que presentaban los materiales, se ideó un proyecto de colaboración entre diversas entidades museísticas locales, laboratorios de análisis y con ciudadanos interesados en la arqueología y la restauración. El programa fue denominado CSI LAB, por analogía con la serie televisiva, (Ternisien: 2012) y bajo supervisión y control de profesionales de la arqueología y la restauración se instaló un laboratorio temporal en un centro comercial de la ciudad, en donde se desarrollaron labores de estudio, manipulación y conservación preventiva de las piezas. Es cierto que, en principio, estas actividades pueden ser un riesgo para establecer un criterio y respeto serios hacía la conservación y restauración científicas o sobre la formación y experiencia de los técnicos, 
pero si se explican debidamente los métodos de trabajo y la necesidad de contar con profesionales cualificados para la conservación del patrimonio, la experiencia puede ser una vía de acercamiento y educación de la población a la que, de este modo, se puede involucrar en la preservación de sus bienes patrimoniales.

En países con menos recursos económicos y un amplio y valioso legado cultural, los aspectos sociales de la conservación y restauración del patrimonio adquieren un papel importante, especialmente cuando se trata de rehabilitar, recuperar y remodelar edificios o piezas y salas de museos. En muchos países pobres, en vías de desarrollo o los considerados como emergentes, con altas tasas de ciudadanos parados, las prioridades para las autoridades locales no son, generalmente, la preservación de sus bienes culturales; la financiación propia para este tipo de proyectos tiene que ser sostenida, también, con dinero de organizaciones internacionales dedicadas a labores de ayuda para la preservación y recuperación del patrimonio. Un problema añadido es la falta de profesionales con una adecuada formación, por lo que es esencial el fomento y creación de facultades, escuelas y centros de estudios para conservadores y restauradores; la educación básica de los ciudadanos es importante para concienciar a la sociedad que con pocos medios es posible ayudar a mantener y salvaguardar el legado histórico. Por ejemplo, en muchos yacimientos arqueológicos urbanos o ciudades muy contaminadas, consejos para mantener limpios el entrono histórico, cómo evitar roturas o daños como consecuencia de actos vandálico, o informar de manera directa acerca de la incidencia negativa de la polución sobre los monumentos, pueden ser modos de concienciar a la población sobre la necesidad de proteger el entorno y los edificios históricos, las colecciones de museos y, a la vez, poner en su conocimiento datos que generalmente se ignoran como: índices de polución en un área urbana, partículas nocivas en suspensión, los sistemas monitorizados para controlar y supervisar los agentes contaminantes, parámetros peligrosos, etc. [figura 6].

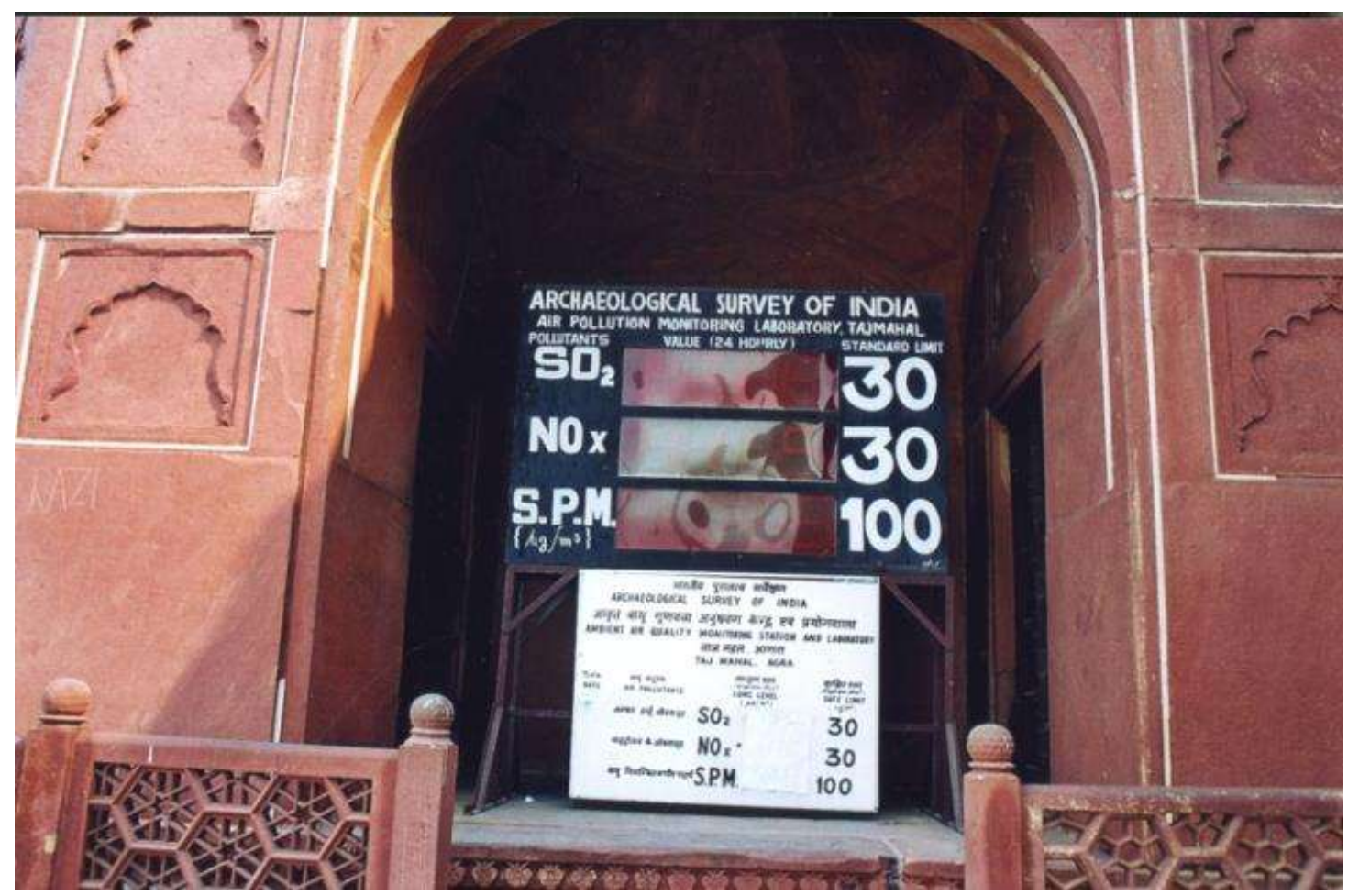

Figura 6. Cartel informativo sobre índices y control de la contaminación en la zona del Taj Mahal (Agra. India). $\mathrm{CM}^{\mathrm{a}}$ Antonia Moreno Cifuentes. 
En países menos favorecidos, gracias a la rehabilitación y restauración de edificios y monumentos arquitectónicos se pueden rescatar muchas técnicas constructivas y decorativas que podrían perderse si no hay una continuidad en la formación de artesanos y técnicos auxiliares. Lo importante es establecer unas líneas de actuación en las que los criterios los marquen siempre especialistas y profesionales, con la colaboración de auxiliares que deberán recibir una formación en conservación y restauración, para de este modo canalizar el potencial que supone su experiencia y conocimiento en labores de apoyo: albañilería, técnicas de estucado, cantería, carpintería, herrería, fontanería, etc. Estos trabajos son fundamentales y suponen una gran ayuda para la recuperación del patrimonio local y sirven, también, para ampliar las perspectivas económicas de la población ya que de este modo se procura trabajo continuado y mejoras en su situación laboral, familiar y social. Hay múltiples ejemplos de países que están desarrollando labores populares y tradicionales para la recuperación de sus bienes culturales, como en India en donde se intervienen palacios del Rajastán con técnicas antiguas de estucados a base de yeso fratado, trabajos en los que participan mujeres; o el caso de Egipto, en donde se usa el adobe fabricado siguiendo el modelo artesanal con barro, paja, excremento de animales y tierra reaprovechada del propio terreno, usando moldes de madera y secados al sol; con ellos se restauran yacimientos arqueológicos, templos y edificios construidos originariamente con este material [figuras 7 y 8 ].
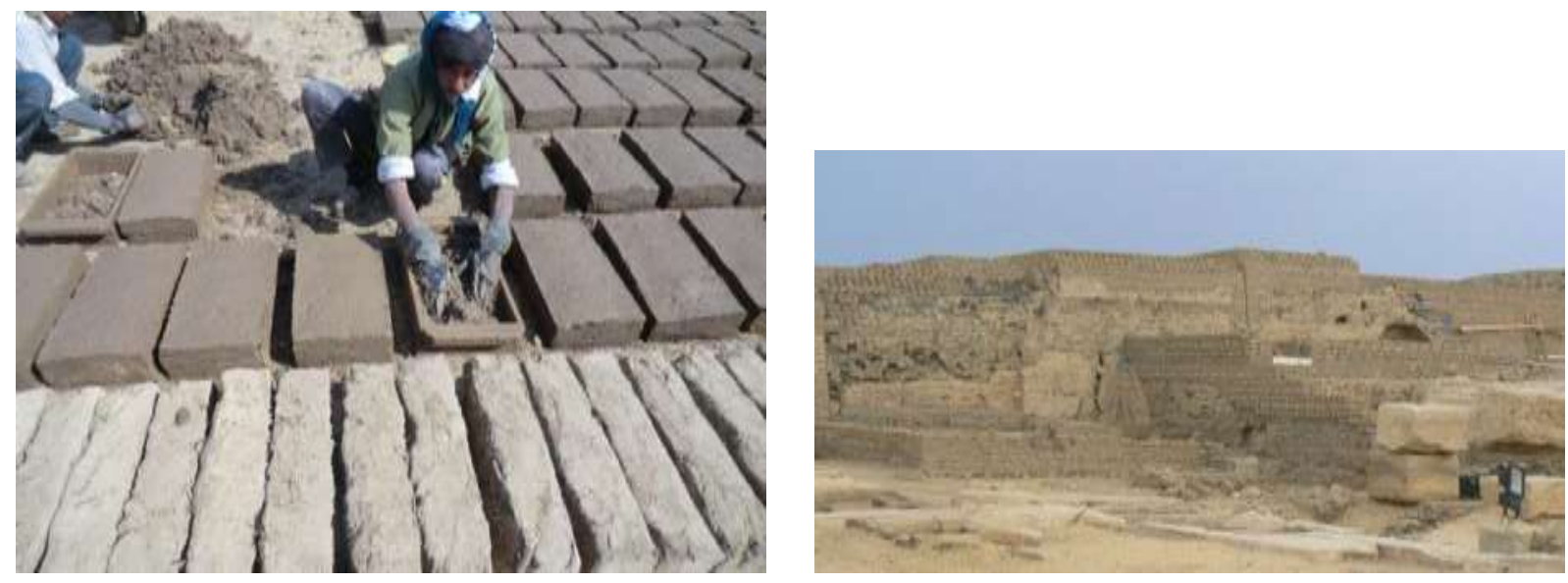

Figuras 7 y 8. Fabricación de adobes con el sistema tradicional. Luxor. Egipto. Restauración del muro de un templo en la West Bank de Luxor con adobes nuevos. (CMa Antonia Moreno Cifuentes.

Son muchas e importantes las instituciones internacionales que actualmente, y por suerte, desde hace años se dedican a educar, asesorar y ayudar a la conservación patrimonial en zonas en las que, además de la falta de recursos, ocurren catástrofes y desastres naturales. En estos países con legados históricos importantes, como ya se ha indicado, sus medios económicos van dedicados a menesteres más perentorios: salud, creación de infraestructuras, alimentación, etc. Es en estos casos cuando la conservación y restauración pueden adquirir protagonismo social y ser una vía para mejorar la calidad de vida de los ciudadanos con el apoyo y colaboración de organismos, cuyos objetivos primordiales y dedicación profesional son la recuperación y salvaguarda del patrimonio cultural. Algunos de estas instituciones -es muy difícil citar a todas- dependen de la UNESCO, como el ICOM, el Centro Internacional de Estudios de Conservación y Restauración de los Bienes Culturales (ICCROM), el Consejo Internacional Monumentos y Sitios (ICOMOS), etc. por considerar algunos de los más notorios; hay otros de carácter nacional que tienen proyectos y 
programas en las mismas líneas de actuación e intentan combinar ayudas sociales con la recuperación de los bienes patrimoniales. También hay instituciones privadas que presentan programas de ayudas económicas, de personal y técnicas a través de fundaciones, oficinas de cooperación, agencias para el desarrollo, etc. con relaciones y conexiones entre sí y entre los gobiernos de diferentes países; la red de Organizaciones No Gubernamentales (ONG) se suman a estas actividades, como es el caso de Restauradores Sin Fronteras, que realiza proyectos en países menos desarrollados ${ }^{7}$ con importantes tareas de docencia y trabajos de campo.

Los cursos teóricas y prácticos que organiza el ICCROM $^{8}$ para formar a conservadores y restauradores especializados en diversos aspectos de la conservación, como arquitectura o pintura mural por ejemplo, son ya tradicionales dentro de las actividades de este centro que prioriza trabajos en países con menos recursos. El ICOM tiene proyectos para la creación y mantenimiento de pequeños museos locales, con la ayuda de programas de educación y formación de los directivos, trabajadores de estos centros y de la población, con soluciones fáciles ante posibles situaciones de emergencia. Cristina Menegazzi $i^{9}$ explicaba hace unos años en una conferencia en el Museo de América en Madrid, los sencillos programas de formación que se imparten en países asiáticos en los que se enseñaba a los vigilantes del museo y habitantes de un pueblo como embalar, proteger o evacuar objetos de la colección etnográfica del centro, ante la posibilidad de una inundación o cualquier otro desastre natural. Un modo de implicar a las comunidades regionales (Menegazzi C. 2007) en la cooperación con los conservadores-restauradores era mediante prácticas de conservación en las que se empleaban objetos del mercado local, de bajo coste económico y muy familiares a todos, tales como abanicos, zapatos, útiles de uso diario, etc., muchos de ellos similares a los que el museo conserva.

Una de las instituciones pioneras en formación y ayuda técnica y logística a sociedades menos desarrolladas, con carencias económicas y de profesionales calificados es el Instituto Getty de Conservación ${ }^{10}$, cuyo campo de acción se ha extendido por numerosos países de Sudamérica y América Central, ribereños del Mediterráneo, África y Asia. Sus programas de formación incluyen todas las áreas de la conservación y restauración, desde cursos y estancias en su sede de California hasta proyectos de trabajo presenciales en importantes monumentos que precisan su intervención. Entre los ejemplos de colaboración más conocidos se encuentra la restauración de la Tumba de Nefertari en el Valle de las Reinas y de la Tumba de Tutankamon en el Valle de los Reyes en Luxor (Egipto), siempre en cooperación con el Supremo Consejo de Antigüedades Egipcias (SCA) (Conservation: 2008). También ha sido importante para la conservación arqueológica en este país The Watering Project, mediante el cual se ha eliminado parte del agua subterránea que por ascensión del nivel freático en zonas de regadíos, situados en la orilla oeste de la antigua Tebas, inundaba muchos monumentos funerarios ubicados en esta zona, esto facilita la conservación de los mismos, así como los trabajos de excavación y de restauración realizados in situ. Este proyecto ha tenido mucha repercusión social para las personas que trabajan en la zona ya que, entre otros resultados, ha facilitado el trabajo continuado de las misiones arqueológicas sin los problemas que se originan en los yacimientos a causa de estas subidas del agua. También el GCl colabora en la señalización y propaganda que de los trabajos de conservación se realizan en diversas tumbas, para mostrar y concienciar a los visitantes sobre la importancia de conservar un patrimonio mundial como el egipcio [figura 9].

La especial situación que vive Egipto tras la revolución de enero de 2011, nos lleva a considerar algunos aspectos de esta especial "primavera árabe" que repercuten en la conservación de su patrimonio cultural. En los primeros momentos de las revueltas se llevaron a cabo actos vandálicos conocidos por todos a través de la prensa e Internet: robos en el Museo Egipcio de El Cairo, destrucción de grupos escultóricos, ataques a yacimientos arqueológicos-especialmente en el 
Medio Egipto y el Delta-, etc. cuyas consecuencias son graves para un legado histórico tan importante. Los efectos se traducen en un control exhaustivo de los proyectos por parte de las autoridades que, actualmente, se relevan con facilidad; existe una mayor demora en la concesión de permisos de trabajo a las misiones internacionales y la menor afluencia turística agrava la crisis económica que se ve reflejada en la reducción de la financiación de proyectos para la conservación. La disminución del personal de vigilancia de los monumentos ha obligado a cerrar algunas tumbas en el Valle de los Reyes y, en las zonas más conflictivas del país, hay dificultad para visitar algunos yacimientos por el temor a nuevos actos vandálicos o de violencia. En consecuencia, las normas que el SCA establece para los equipos que trabajan en yacimientos son cada vez más estrictas y vigiladas a diario por los inspectores arqueológicos y de restauración egipcios: el pormenorizado control de los hallazgos, las piezas hay que guardarlas a diario en el almacén, no pueden quedar objetos muebles en la excavación ante el temor de un ataque antrópico, se vigila el horario y una vez terminada la jornada laboral no se admiten trabajos en el yacimiento, salvo con un permiso especial, y es necesario obtener la autorización oficial para cualquier analítica, toma de muestras, etc. Estos son algunos de los aspectos que influyen actualmente en la conservación del patrimonio egipcio, objetivo muy importante para las autoridades que exigen se presenten intervenciones y procedimientos de restauración cuando se plantea un proyecto arqueológico.

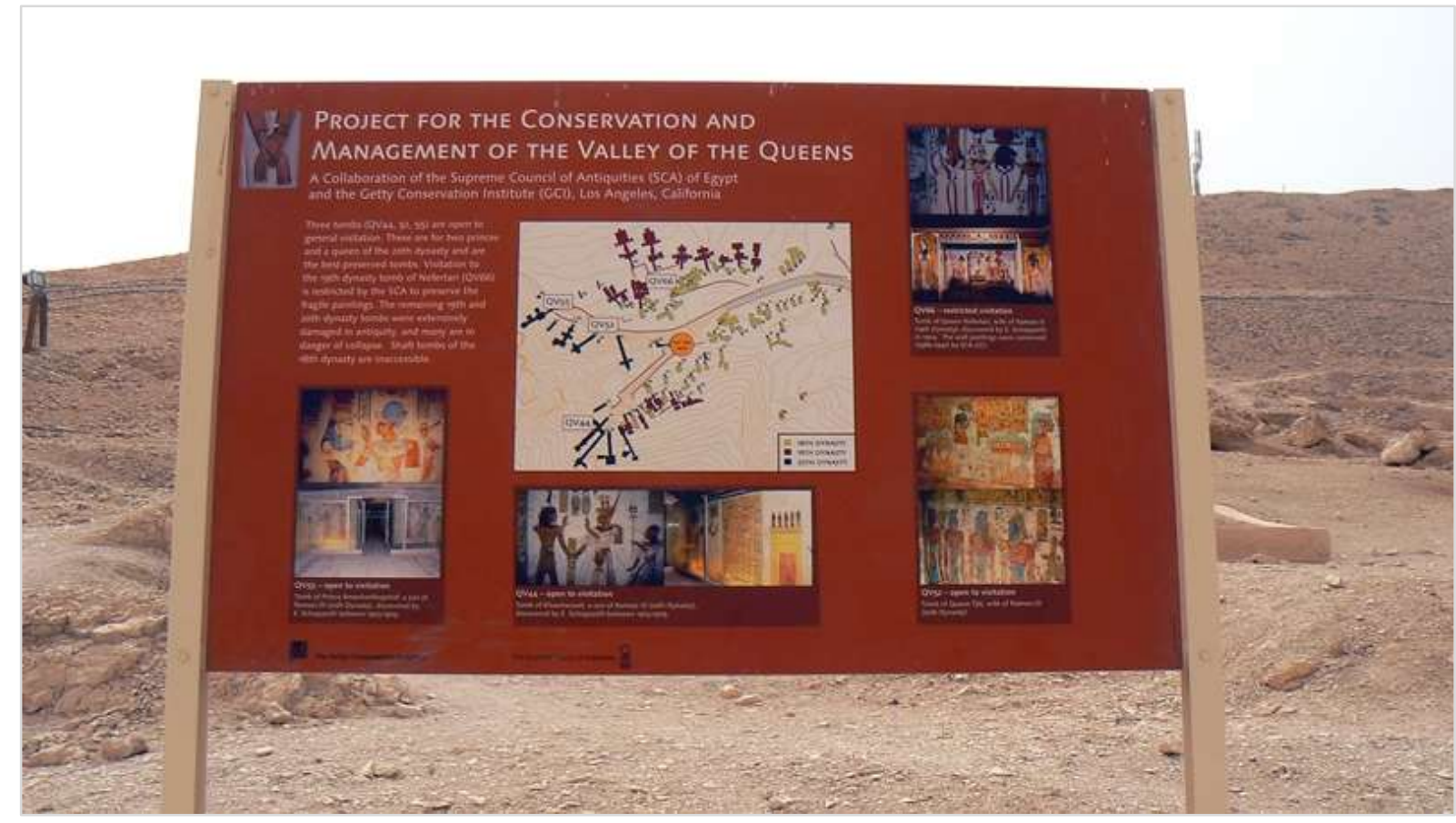

Figura 9. Cartel explicativo sobre la conservación y puesta en valor de las tumbas en el Valle de las Reinas (Luxor, West Bank); proyecto de colaboración entre el Consejo Supremo de Antigüedades Egipcias y el Instituto Getty de Conservación. @Ma Antonia Moreno Cifuentes.

La Fundación Aga Khan (Aga Khan Fundation -AKF- y Aga Khan Trust for Culture - AKTC-) ${ }^{11}$ es una institución privada que se fundó en 1988 y tiene su sede en Ginebra, desde donde se coordinan trabajos sociales, de ayuda al desarrollo y revitalización, junto con apoyos para la conservación y restauración de ciudades y monumentos en comunidades y países islámicos. Los proyectos se extienden por lugares con un legado cultural amplio y muy valioso que en muchas ocasiones se ve amenazado por cuestiones económicas y, en otras, por conflictos sociales o desastres naturales. 
Muchos de estos países tienen serios problemas de salud y pobreza como son Malí, Afaganistán, Kenya, Zanzíbar, India, Pakistán y Tayikistán, Bosnia, etc. Entre los planes más importantes desde el punto de vista social es el Programa para Ciudades Históricas Aga Khan (HCP) (http://www.akdn.org/hcp/) cuyo objetivo es promover la conservación y la reutilización de edificios y espacios públicos en ciudades históricas mediante acciones que estimulan el desarrollo social, económico y cultural, con intereses que van más allá de la restauración técnica, tratando de resolver los problemas en el contexto social y ambiental. Los trabajos que se han realizado en EI Cairo para recuperar un espacio y barrio degradados, como el caso del Parque del Azahar ${ }^{12}$ situado frente a la antigua ciudadela, han hecho de este lugar uno de los más visitados actualmente por los ciudadanos; también han colaborado en la formación de restauradores y técnicos, así como en la restauración de objetos para la reapertura del museo islámico en el Old Cairo.

Otras iniciativas interesantes que se están llevando a cabo en algunos países son las "Escuelas de Campo" o Field Schools; se dirigen, entre otros, a profesionales de la arqueología, de la conservación arquitectónica y la restauración de objetos. La Universidad Americana del Cairo, en colaboración con SCA, comenzó estas actividades hace ya varios años para formar, especialmente, a arqueólogos egipcios en técnicas de excavación, documentación, conservación, museología y gestión de los monumentos. Actualmente el American Research Center in Egypt (ARCE) ${ }^{13}$ está desarrollando en esta misma línea un programa de actividades con la ayuda financiera de la Agencia de EE. UU. para el Desarrollo Internacional (USAID); las clases prácticas se imparten in situ por conservadores-restauradores de distintas nacionalidades, y con amplia experiencia en conservación y restauración arqueológicas. Los trabajos se desarrollan en varias áreas de Luxor y en el Monasterio Rojo de Sohag, siendo uno de los más interesantes, desde el punto de vista social, el que se lleva a cabo en la zona de las aldeas de Sheik Abd el Qurna ${ }^{14}$ y Khokha, como respuesta a la situación creada tras la revolución de enero de 2011 y para recuperar estas zonas, muy degradadas y actualmente sin turismo. Unos 600 obreros han sido contratados, muchos de ellos habitantes de la zona, con la finalidad de limpiar y mantener las antiguas casas y callejas, contribuir a mejorar la apariencia mediante la eliminación de la suciedad y materiales que quedaron acumulados tras la demolición de las viviendas más nuevas $y$, de este modo, facilitar el acceso a los visitantes (http://www.arce.org/conservation/Qurna/qurna) [figura 10].

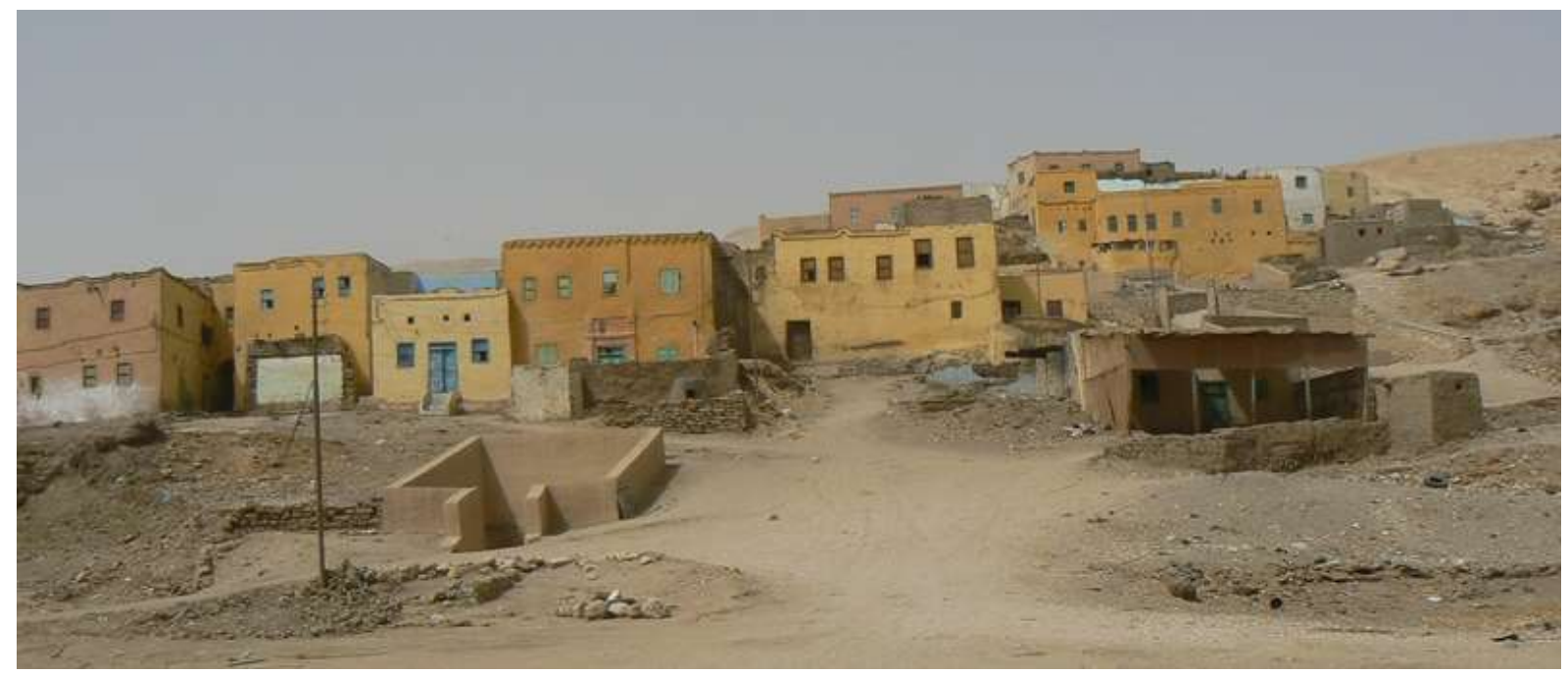

Figura10. Aspecto general de la aldea del Qurna en la actualidad tras su limpieza y programa de mantenimiento. $\odot M^{a}$ Antonia Moreno Cifuentes. 
En España, la Agencia de Cooperación Internacional para el Desarrollo (AECID), entidad adscrita al Ministerio de Asuntos Exteriores, tiene proyectos de asistencia y ayuda financiera a diversos países y juega un papel importante en la conservación del patrimonio, especialmente en Iberoamérica; en sus programas de educación colaboran técnicos del Instituto de Patrimonio Cultural de España y de la Subdirección General de Museos Estatales del Ministerio de Educación, Cultura y Deporte que imparten cursos de formación y clases prácticas para conservadores-restauradores en casi todo el sur y centro de América. Gracias a su programa Patrimonio para el Desarrollo (Programa $\mathrm{P}<\mathrm{D}$ Patrimonio para el Desarrollo) se sustentan y financian proyectos de conservación de bienes culturales, habiéndose creado y mantenido Escuelas Taller que, si bien en nuestro país se han visto muy cuestionadas por los trabajos de restauración que realizan sus miembros sin la formación adecuada, en muchos lugares de América Latina han servido para rescatar oficios tradicionales para que los jóvenes se inserten en el mercado laboral. Por citar algunos ejemplo de estos proyectos: las E. T. de Arequipa, Ayacucho, Lima (Perú), de Sucre (Bolivia); el programa de conservación de Patrimonio Cultural del Valle del Colca en Arequipa, en el que se restauró de manera integral y puso en valor el conjunto de templos virreinales con una apuesta por la recuperación de la arquitectura tradicional y de los núcleos urbanos, en colaboración con el obispado de la ciudad. También en Cairo, hace ya varios años, se restauró el Sabil Kuttab Qâit-Bây en el mismo edificio se conjuntan una fuente pública del siglo XV y una escuela coránica - y la iglesia copta de Abu Sirga; en el primer caso el edificio se había visto seriamente dañado por el terremoto del año 1992 y tras su recuperación, su destino final ha sido como centro cultural dependiente del Ministerio de Cultura Egipcio; en el segundo, se llevó a cabo la restauración de iconos y el baldaquino del templo junto con una catalogación e inventario de sus bienes muebles ${ }^{15}$.

En este breve recorrido sobre algunos de los aspectos y relaciones que la conservación y restauración tienen con la sociedad, no se ha incluido la preservación del patrimonio intangible que tiene, también, sistemas y métodos para su conservación pero que precisa de tratamientos diferentes. Cada día más, los organismos e instituciones públicas y privadas están implicados en educación, formación y acercamiento ciudadano ante los bienes culturales y buena muestra de ello son los múltiples congresos que sobre patrimonio, conservación y cooperación se celebran periódicamente, para poner en contacto a los diversos gobiernos e instituciones con técnicos y especialistas en el campo de la conservación y restauración. En el IV Congreso Internacional de Patrimonio y Cooperación al Desarrollo, organizado por el Instituto Andaluz del Patrimonio Artístico (IAPH) y la AECID en 2010 y en el que participaron técnicos y estudiosos en estas materias, podemos encontrar interesantes trabajos y opiniones para comprender mejor los aspectos sociales de la conservación y restauración del patrimonio mundial. En las conferencias que impartieron Luís Monreal desde el Programa de Ciudades Históricas de la Fundación Aga Khan para la Cultura y Sami Naïr ${ }^{16}$, se expusieron varias ideas notables sobre conservación y estrategias para combatir la pobreza, como son las de "crear entidades autosuficientes, autónomas, que puedan producir ingresos que se reviertan en los bienes conservados" y también que "la defensa de la conservación del patrimonio es la defensa del ser humano" (Naïr S. 2010).

\section{Notas}

[1] La empresa Factum Arte se dedica desde hace varias décadas a reproducciones digitales y escaneadas de obras de arte y monumentos, entre los que se encuentra: la tumba de Tutmosis III, de Tutankamon, la Restauración digital de la pared del paisaje de la Sala de Bolonia en el Vaticano, etc. Para conocer más sobre sus proyectos consultar: http://www.factum-arte.com/eng/default.asp. 
[2] Un ejemplo puede ser el caso del Museo Arqueológico Nacional, cerrado en la actualidad, que ofrece en su página web un recorrido por la obras de remodelación del edificio, labores de restauración y nuevo montaje de las salas. Para consultas: http://man.mcu.es/

[3] Para ver toda la información acerca de la restauración y conservación de Adán y Eva de Albert Durero ver:

http://www.museodelprado.es/

http://www.museodelprado.es/investigacion/restauraciones/

http://www.museodelprado.es/investigacion/restauraciones/restauracion-de-emadanem-yemevaem-de-durero/

http://www.museodelprado.es/exposiciones/info/en-el-museo/instalacion-especial-adan-y-eva-dedurero-tras-su-restauracion/

[4] En las noticias acerca de las actividades del Día Internacional de los Museos, la página web del ICOM explica: "Actividades dirigidas al público en general: Visitas: Actos de inauguración de un museo o de nuevas salas; Visitas guiadas a colecciones que habitualmente no se exponen o han sido recientemente restauradas..., Visitas guiadas por especialistas".

http://www.icom-ce.org/contenidos09.php?id=44 [consulta: 21/4/2013].

[5] Para conocer más acerca de este proyecto consultar página web: http://www.museothyssen.org/microsites/tintoretto/intro_restauracion.html

[6] Para conocer más acerca de este proyecto consultar página web: http://www.catedralvitoria.com http://www.catedralvitoria.com/restauracion_introduccion.php http://www.catedralvitoria.com/visitas_finalidad.php

[7] Para conocer más sobre esta ONG, consultar: http://www.a-rsf.org/

[8] Para conocer los proyectos y actividades del ICCROM, ver: http://www.iccrom.org/

[9] Cristina Menegazzi es conservadora en el ICOM, consultora y especialista en conservación preventiva, con amplía experiencia en programas de formación y ayuda a países de América Latina, Asia, África, Países Árabes, Oceanía y Europa. Coordina programas de conservación en el Centro de Patrimonio Mundial de la UNESCO.

[10] Ya que es una institución muy reconocida entre los profesionales de la conservación, para saber más acerca de sus actividades, se aconseja visitar su página web., en la que se especifican noticias sobre proyectos, formación profesional y recuperación de oficios, restauraciones en curso, publicaciones, etc. también es posible contactar con ellos y unirse a su red social Facebook.

http://www.getty.edu/conservation/

http://www.getty.edu/conservation/publications_resources/teaching/index.html http://www.getty.edu/conservation/publications_resources/videos/project_videos.html

[11] Es en África y Asia donde la Fundación Aga Khan desarrolla sus actividades de forma mayoritaria. Para conocer más acerca de la institución consultar: http://www.akdn.org/AKF

[12] Ver: Egipto: el Proyecto Parque Azhar en el Cairo y la conservación y revitalización del Darb al-Ahmar. En: http://www.akdn.org/hcp/egypt.asp

[13] Para más información consultar página web del ARCE: http://www.arce.org/main/training/fieldschools

[14] Las casas más nuevas y en ruina de la aldea del Qurna fueron demolidas hace unos años porque en este lugar se habían construido casas sobre tumbas antiguas; a sus moradores se les dieron nuevas viviendas en la zona denominada como New Qurna, situada unos kilómetros más lejos al norte y el este, cerca del Templo de Seti I. La decisión de las autoridades y del Supremo Consejo de Antigüedades fue muy polémica, ya que muchas personas se resistieron hasta el final a dejar sus viviendas.

[15] Para conocer proyectos y actividades de la AECID consultar: 
http://www.aecid.es/es/ http://www.aecid.pe/proyectos/index.php?idProy=19 http://www.aecid.pe/proyectos/index.php?idProy=12 http://www.uclg-cisdp.org/es/el-cairo-egipto-programa-de-rehabilitación

[16] Luís Monreal es director de la Fundación Aga Khan para la Cultura y Sami Naïr es sociólogo y filósofo especialista en movimientos migratorios y que acuñó el término co-desarrollo. Para información acerca de este interesante congreso se puede consultar:

http://www.iaph.es/web/portal/actualidad/contenido/noticiacongresopatrimonio_junio2010 http://www.iaph.es/export/sites/default/sites/patrimonioydesarrollo/LibroActas.pdf

\section{Bibliografía}

AGRAWAL, O. P. (1975). “An Asian Wiew of Conservation". En Museum Internacional, vol. 27, 4, París, UNESCO: 157-160 CONSERVATION (2008). The Getty Cnservation Institute Newsletter. Volumen 23, № 2. 2008.

GONZÁLEZ PENA, M. L. y MORENO CIFUENTES, M. A. (1991). “Aproximación del niño al mundo de la restauración". En VII Congreso de Conservación de Bienes Culturales, Bilbao. Departamento de Cultura y Turismo del Gobierno Vasco, 33-52.

MENEGAZZI, C. (2007). "Iniciativas de gestión del riesgo en el ICOM". En Actas del III Congreso del Grupo Español de International Institute for Conservation (GE-IIC). La conservación infalible: de la teoría a la realidad. Oviedo 2007. http://ge-iic.com/files/3Congreso/Menegazzi.pdf [consulta 25/04/2013].

NAÏR, S. (2010). http://www.lahornacina.com/noticiasiaph34.htm [consulta 11/04/2013].

TERNISIEN, V. (2009). "Conservation in action: welcome to CSI Lab". Revista e-conservation, № 12, 25-35. http://www.e-conservationline.com/content/view/837/ [consulta 29/04/2013].

\section{Referencia a consultas en línea (Internet)}

http://www.museodelprado.es/ [consulta: 15/04/2013].

http://www.museodelprado.es/investigacion/restauraciones/ [consulta: 15/04/2013].

http://www.museodelprado.es/investigacion/restauraciones/restauracion-de-emadanem-y-emevaem-dedurero/ [consulta: 16/04/2013].

http://www.museodelprado.es/exposiciones/info/en-el-museo/instalacion-especial-adan-y-eva-de-durerotras-su-restauracion/ [consulta: 16/04/2013].

http://www.icom-ce.org/contenidos09.php?id=44 [consulta: $21 / 4 / 2013]$.

http://www.museothyssen.org/microsites/tintoretto/intro_restauracion.html [consulta: 21/4/2013].

http://www.catedralvitoria.com [consulta: 23/4/2013].

http://www.catedralvitoria.com/restauracion_introduccion.php [consulta: 23/4/2013].

http://www.catedralvitoria.com/visitas_finalidad.php [consulta: 23/4/2013].

http://www.akdn.org/hcp/ [consulta: 14/4/2013].

http://www.arce.org/main/training/fieldschools [consulta: 14/4/2013].

http://www.arce.org/conservation/Qurna/qurna [consulta: 16/4/2013].

http://www.aecid.es/es/ [consulta: 19/4/2013].

http://www.aecid.pe/proyectos/index.php?idProy=19 [consulta: 19/4/2013].

http://www.aecid.pe/proyectos/index.php?idProy=12 [consulta: 19/4/2013]. 
http://www.uclg-cisdp.org/es/el-cairo-egipto-programa-de-rehabilitación [consulta: 19/4/2013].

http://www.e-conservationline.com/content/view/837/267/ [consulta: 19/4/2013].

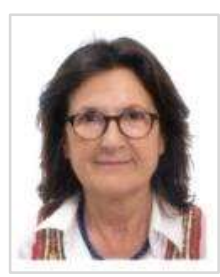

\section{María Antonia Moreno Cifuentes}

antoniamorenoc@gmail.com

Licenciada en Filosofía y Letras y restauradora en la especialidad de materiales arqueológicos. Trabajó en varios museos como Burgos, Zaragoza y desde 1992 en el Museo Arqueológico Nacional. Ha colaborado y participa en proyectos de investigación con varias misiones arqueológicas españolas y extranjeras en Pompeya (Italia) y Egipto; en este país, desde 1995, es la responsable de los trabajos de conservación y restauración en el Proyecto del Museo Arqueológico Nacional en Heracleópolis Magna (Beni Souef). También pertenece a los equipos que trabajan en la excavación, restauración y puesta en valor de los templos funerarios de Amenhotep III y Tutmosis III, ambos en Luxor. 


\title{
Entrevista con Ángel Macarrón, una vida al servicio del arte
}

\author{
Por Rocío Bruquetas Galán y Ana Calvo Manuel
}

Conocer la labor de nuestros antecesores en la conservación del patrimonio cultural nos ayuda a analizar e interpretar mejor la realidad actual. Las luchas personales y colectivas que han forjado la historia más reciente de esta profesión no se pueden entender sin la dedicación y el trabajo de muchas personas que nos precedieron. La revista $\mathrm{Ge}$ conservación pretende con estas entrevistas captar y dar a conocer de una forma cercana las vivencias humanas y profesionales de aquellas personas que han dedicado su vida a la protección de los bienes culturales.

Ángel Macarrón, cuyo apellido resuena tan familiar a todos los que pertenecemos al mundo de la restauración, ha accedido con franco entusiasmo a que le entrevistemos para este número. Nace en Madrid en 1920, en el seno de una saga familiar vinculada desde finales del siglo XIX al comercio $y$ fabricación de materiales artísticos, al montaje de exposiciones y al transporte y restauración de obras de arte. Desde muy joven comienza a trabajar en la empresa familiar, iniciándose en 1939 con el viaje a Ginebra, junto a su tío Juan, para traer los cuadros que

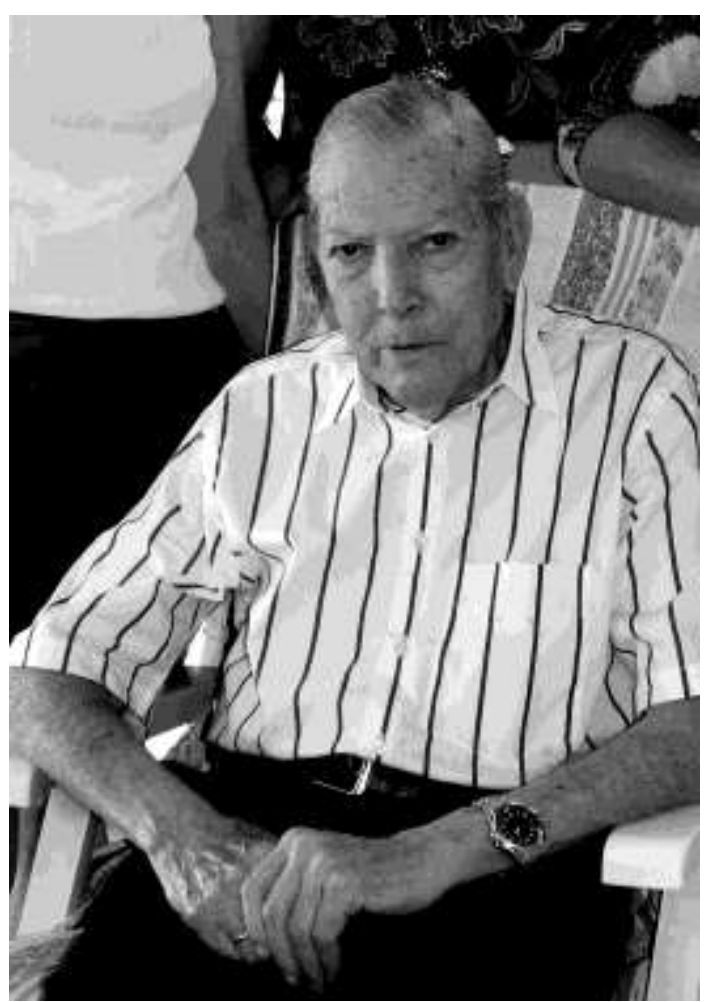

Ángel Macarrón fueron trasladados a Suiza durante la Guerra Civil española. Su primera formación en los talleres de la Casa Macarrón y su paso por la Escuela de Artes y Oficios de Madrid se completó, como autodidacta, con sus propias experiencias en el campo de la restauración de obras de arte. Su vida profesional está jalonada de intervenciones históricas relacionadas con lo mejor de nuestro Patrimonio Cultural.

Ángel Macarrón transmite, a sus 92 años, una formidable energía y vitalidad que se activa con cada uno de los recuerdos narrados en la entrevista. En efecto, la conversación transita entre los inicios de una empresa familiar por la que han pasado cuatro generaciones dedicadas al del arte, al llegar al Madrid decimonónico del fundador de la saga, su abuelo Don Ángel Macarrón, y el momento actual, ya desaparecida la conocida empresa, con las nuevas generaciones representadas por sus hijos Ana María y Javier, y su nieta Rita.

No hay duda, pues, de que es un apasionado de su trabajo. Si a ello se une el trasfondo histórico de los hechos relatados, las dos horas de entrevista se convierten en un fascinante recorrido por la historia de la conservación en la España del siglo XX. 


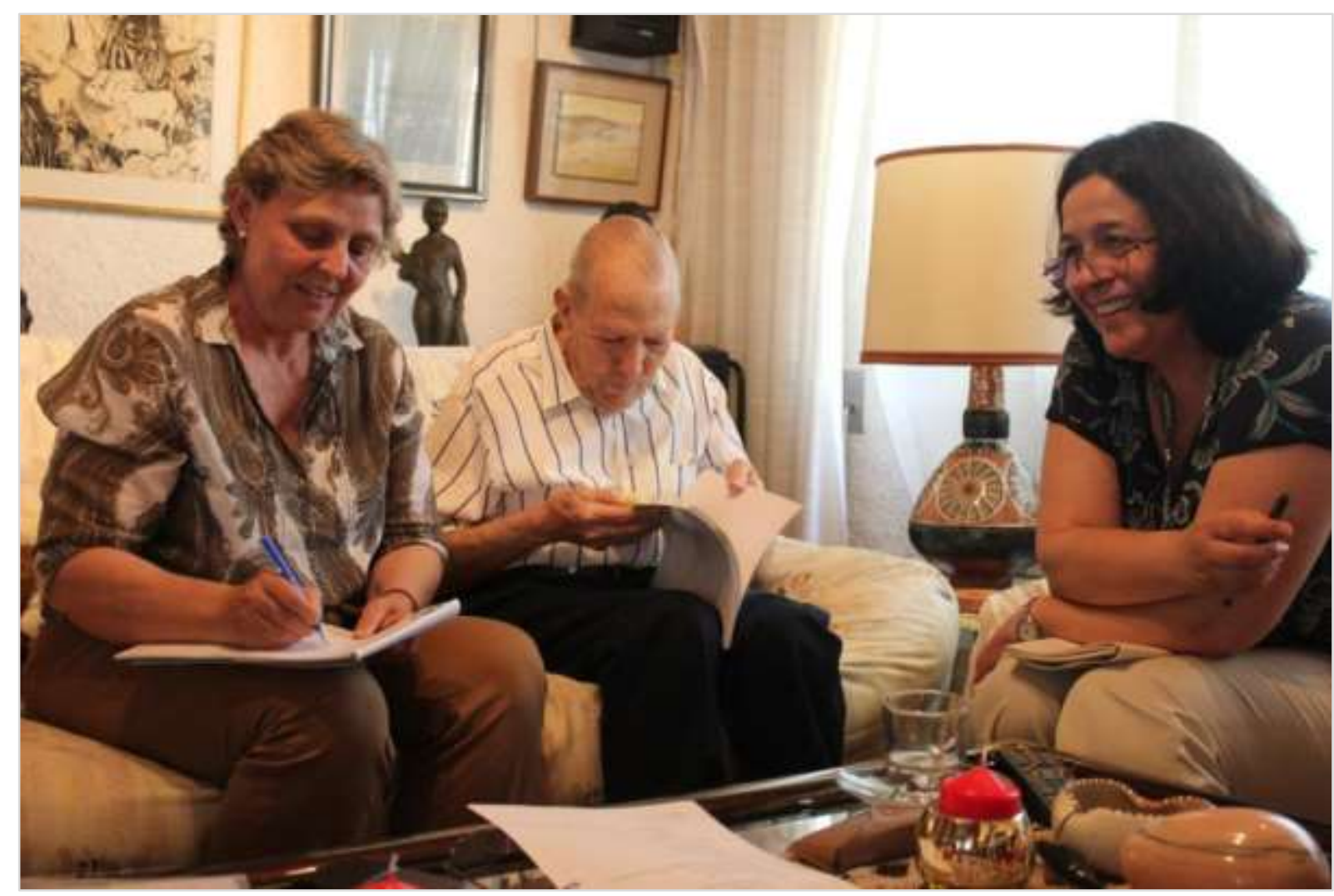

De izquierda a derecha; Ana Calvo, Ángel Macarrón y Rocío Bruquetas

\section{Entrevista}

\section{Nos gustaría comenzar la entrevista por del origen de este histórico establecimiento madrileño y con tus recuerdos de la niñez en la tienda.}

Mi abuelo Ángel Macarrón era oriundo de Valdanzo, Soria. Vino a Madrid de muy joven para aprender un oficio, y a los 14 años entró como meritorio en "La Paleta Artística", establecimiento de la calle Santa Catalina especializado en lo que se llamaba "artículos para pintores de Historia". A esta famosa casa acudían pintores como Palmaroli, Domingo Marqués, Emilio Sala, Pradilla, Martínez Cubells, Ignacio Pinazo, Haes, Aureliano de Beruete ... Allí aprendió a estirar e imprimar lienzos, moler y preparar colores, que aún no se despachaban en tubos sino en vejigas, también a forrar cuadros y preparar embalajes.

En 1895 fundará su propio negocio, teniendo como socio a un cliente y amigo, Mateo Silvela, hermano de los famosos políticos Manuel y Francisco, inicialmente llamado "La España Artística". Estaba localizada en la calle Jovellanos $n^{\circ} 2$, una buena zona, junto al Círculo de Bellas Artes, la Real Academia de San Fernando y el Museo del Prado. Se dedicaba a la fabricación y venta de materiales de Bellas Artes: lienzos, bastidores y otros soportes, barnices, aceites y otros aglutinantes, pigmentos, colores ya preparados, acuarelas. No había por entonces muchas tiendas especializadas en materiales artísticos que no fueran droguerías.

Mi abuelo murió a los tres años de abrir el negocio y se hizo cargo de él su viuda, Doña Eladia Despierto. Pronto participarán también sus cuatro hijos: Graciano, mi padre, y mis tíos Juan, Juliana y Marcelino. Más tarde se sumarán algunos de los nietos, entre ellos los hijos de Graciano, mis 
hermanos Rafael, Graciano y yo mismo. El negocio se amplió también al montaje de exposiciones, embalaje, transporte y restauración de obras de arte. Incluso tenía su propia sala de exposiciones para difundir las obras de nuevos artistas. En la tienda nacieron mi padre y mi tía, en la parte de atrás, pues arriba estaba la vivienda.

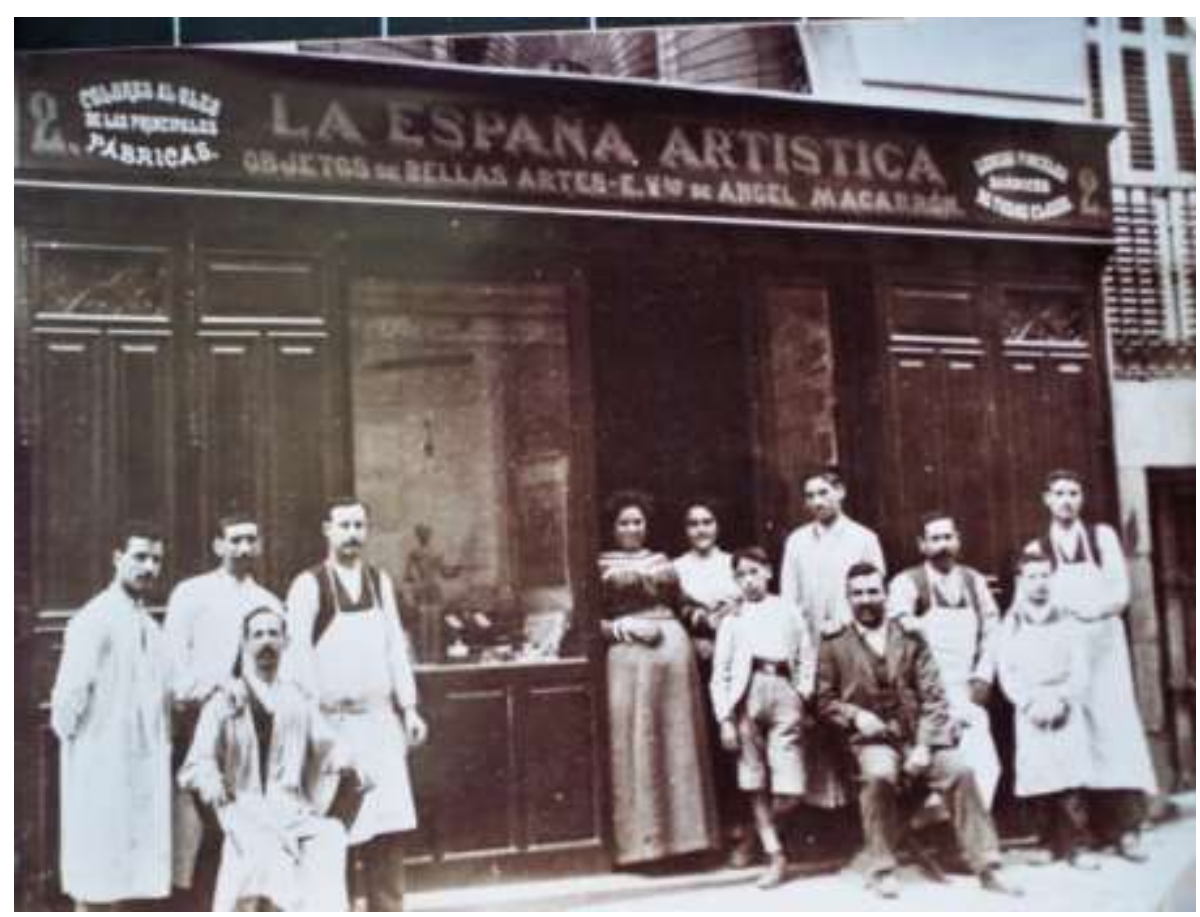

Eladia Despierto en el centro de la imagen, en la puerta de la primera tienda, "La España Artística". En el grupo de la izquierda aparece su hermano Alejandro Despierto, forrador del Museo del Prado.

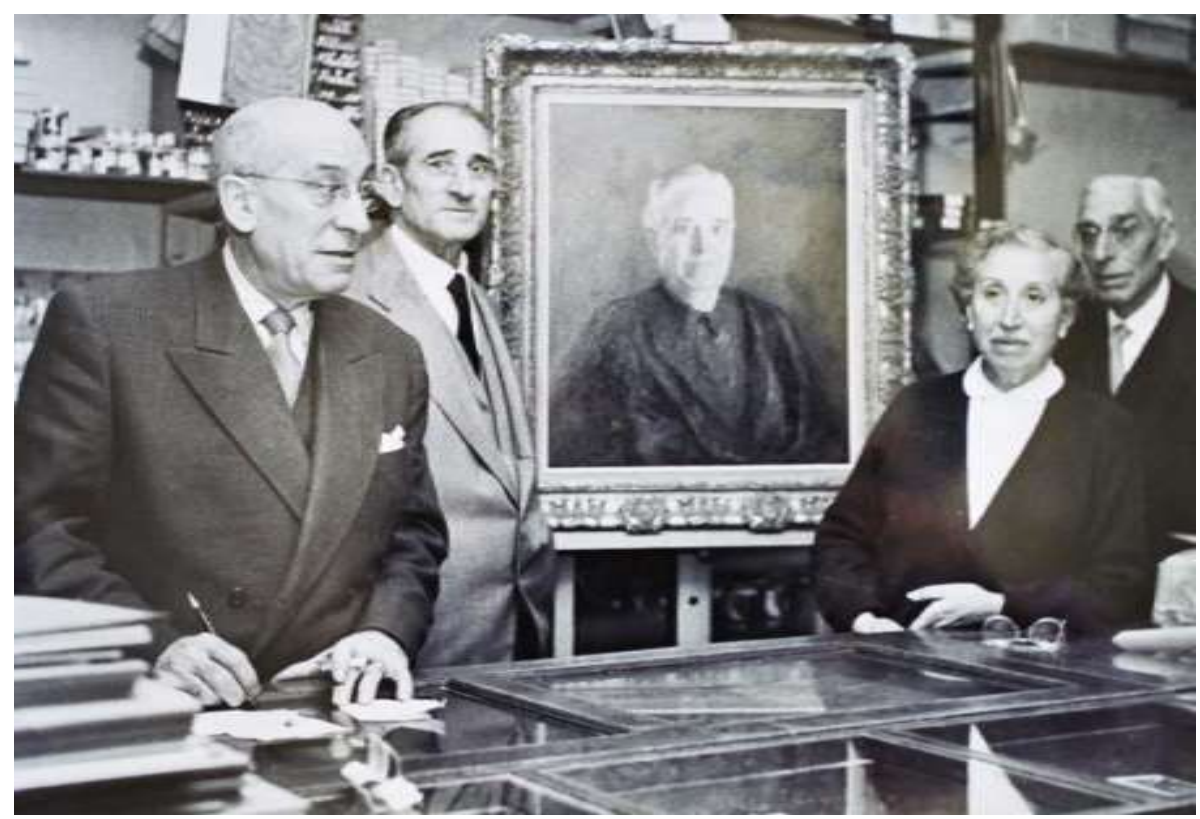

Los cuatro hermanos Macarrón junto al retrato de su madre, Eladia Despierto, fundadora de la Casa Macarrón. De izquierda a derecha, Graciano, padre de Ángel, Juan, Juliana y Marcelino. 


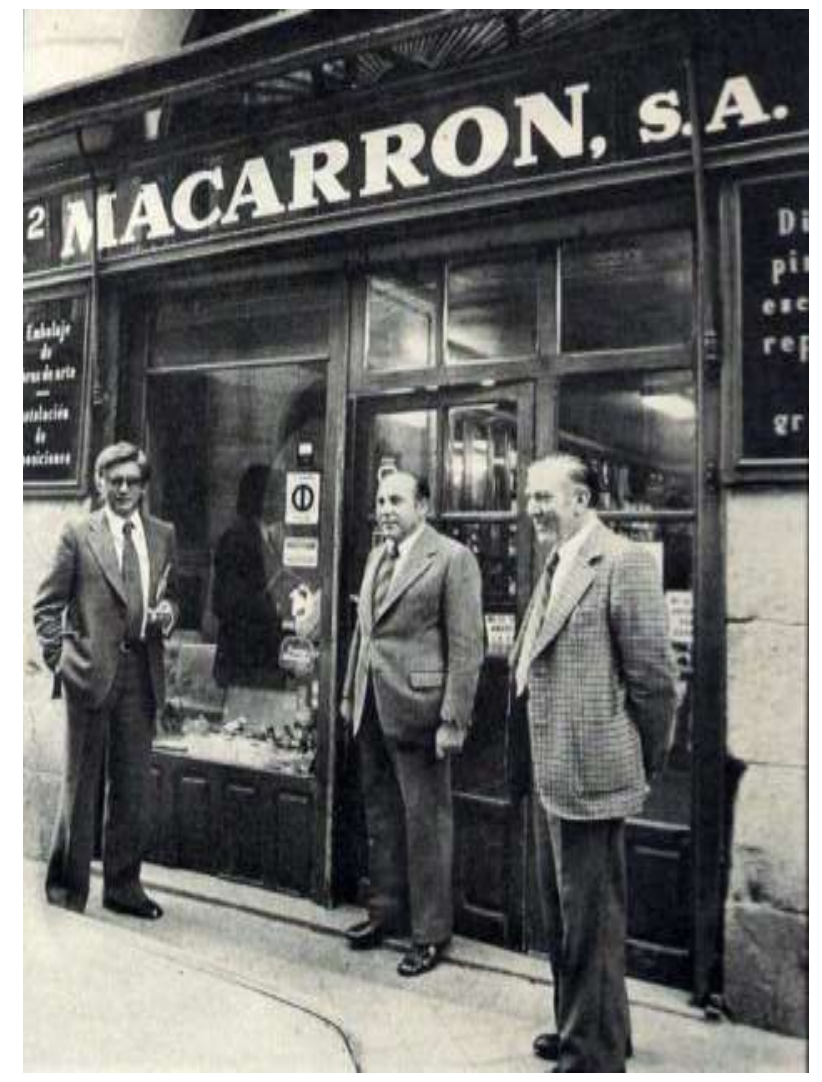

Jesús, Rafael y Ángel Macarrón en la madrileña calle de Jovellanos

La Actualidad Española, no 1226, de 7 de julio de 1975, publicó un extenso reportaje sobre la saga familiar de los Macarrón. Comienza relatando los comienzos del fundador del establecimiento en "La Paleta Artística" y nos Ilama la atención cómo su abuelo aprendió allí a moler colores al óleo, a lavar tierras ocres, sienas y tierras de Sevilla, a extraer el aceite de nueces, ... prácticas artesanales que ya desaparecieron. ¿Cómo eran los materiales que surtía la tienda en estos primeros tiempos?

Sí, ellos preparaban los materiales. En el caso de los pigmentos, las tierras solían ser españolas (eran muy buenos los ocres de Levante y las tierras de Sevilla), mientras que los colores finos se traían de Francia, Alemania e Inglaterra. Había que molerlos y meterlos en tubos, preparábamos nuestros propios colores al óleo de marca Macarrón. En esos tiempos sólo fabricaban colores los Zuloaga y nosotros. También preparábamos lienzos, que se hacían según encargo. Utilizábamos diferentes procedimientos, por ejemplo, cola de conejo, caseína o aceite con yeso, blanco de España o blanco de cinc como cargas. Algunos pintores pedían imprimaciones particulares, como los Zubiaurre, que imprimaban con tierra de Sevilla o con azul de Prusia. Sorolla pedía pinceles y brochas con los mangos empalmados porque solía poner la paleta en el suelo para pintar.

Se ofrecían telas ya preparadas, y también cartones, tablas engatilladas y, en época más moderna, tablex y contrachapados. Otro producto que se preparaba en la tienda eran los barnices, principalmente de almáciga y más tarde de damar, con esencia de trementina. Y pinceles, especialmente después de la guerra, los hacíamos de meloncillo (pelo de gato montés) y de marta (del pelo de la cola o del lomo). Luego se dejó de fabricar colores a mano porque no interesaba económicamente y se importaban de fuera. 
La tienda era también un lugar de reunión para artistas y aficionados. Había un banco a la entrada en la que se sentaba la gente, lo hizo por ejemplo la reina Victoria Eugenia, que vino a comprar unos pinceles de acuarela. Por allí pasaron Zuloaga, Sert, Chicharro, Rusiñol, Dalí, Romero de Torres, Saura, incluso Robert Kennedy fue allí a enmarcar unos cuadros que había comprado en el Rastro. Sorolla iba poco pero algunas veces hacía tertulia con Lardhy y Borrel. Rusiñol se solía citar en la tienda con la Xirgú y otros amigos. Romero de Torres mandaba normalmente a una modelo a comprar los materiales. También fue cliente de la casa Pablo Picasso, aunque no lo recuerdan por allí, pero su sello figura en los bastidores de muchos de los cuadros que el pintor donó a Barcelona.

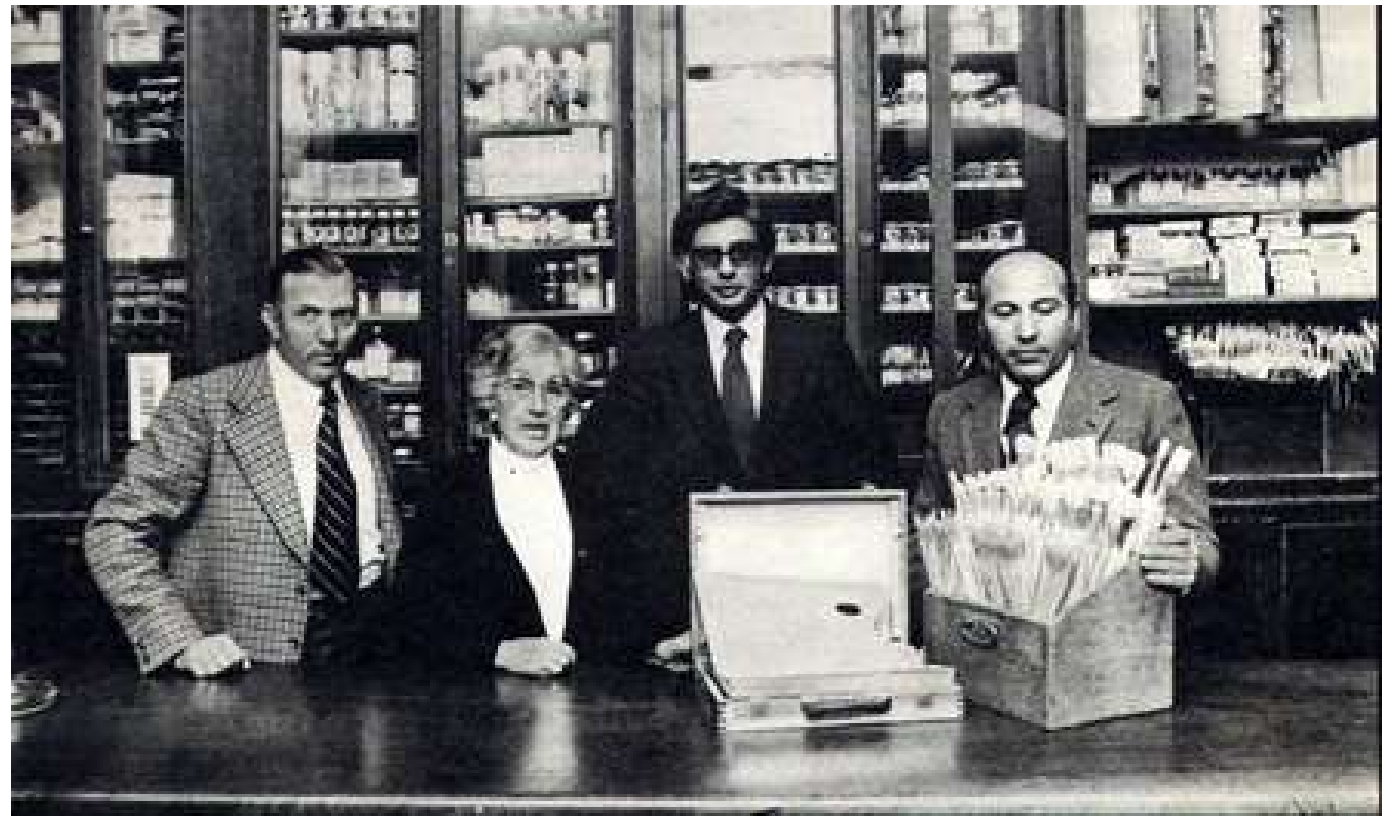

De izquierda a derecha: Ángel, Juliana, Jesús y Rafael Macarrón

\section{Tenían también su propia sala de exposiciones y se dedicaron al embalaje y transporte de obras} de arte.

Se inauguró después de la guerra. Expusimos obras de clientes veteranos, como Sorolla, Ricardo Baroja, Solana, Marceliano Santamaría, Benjamín Palencia, Joaquín Vaquero, Martínez Novillo. Se encargaba de los programas de exposiciones Rafael Macarrón. Nos interesaba descubrir nuevos valores.

Al incorporarse al negocio mis tíos se ampliaron las actividades y empezamos a dedicarnos $-\mathrm{y}$ en eso creo que fuimos empresa pionera en España- al transporte y embalaje especializado de obras de arte, así como al enmarcado y montaje de exposiciones.

\section{En muy poco tiempo se convertirán en expertos no solo en España, sino también en el extranjero, desde donde serán reclamados en numerosas ocasiones.}

La primera exposición de la que se encargó la Casa Macarrón fue la de Arte Belga celebrada en el palacio de Exposiciones del Retiro, en los años de la Primera Guerra Mundial. Se hicieron el enmarcado, embalaje, traslado y montaje de las obras. Después la de Arte Francés, allí mismo. En 
1919 se celebró la exposición de Arte Español en Londres, para cuyo montaje se trasladó allí mi tío Juan, y unos años después también se le encargarán a la Casa Macarrón los embalajes de otra exposición de arte español en París, a la que iban varios cuadros de Goya del Museo del Prado. La Venus del Espejo de la National Gallery de Londres vino para la exposición de Velázquez, y después de consultar a especialistas de París, Roma y Londres, se decidieron por los Macarrón. También se nos confió el transporte a San Antonio, en Tejas, de una exposición de obras de nuestros mayores pintores: el Greco, Goya, Velázquez, Ribera; y la gran exposición de Goya en la Galería Nacional de Londres.

La Guerra Civil será un momento crucial ya que la Junta de Incautación del Tesoro Artístico Nacional y el Museo del Prado encargaron a la Casa Macarrón el embalaje de las obras de arte que debían trasladarse para su protección a Valencia y después a Ginebra. Hay una magnífica documentación sobre las características de los embalajes con que acondicionaron las obras, tanto escrita como fotográfica (la mayor parte de ella conservada en el Instituto del Patrimonio Cultural de España), y se han publicado varios estudios sobre los aspectos técnicos de esta extraordinaria empresa que fue la protección de las obras de arte durante la guerra española (ver bibliografía). Sin embargo, queremos oír de su propia voz los recuerdos de aquella experiencia.

Los embalajes se hacían con cajas de madera, machihembradas, que se forraban por dentro con papel embreado. Los cuadros se envolvían en papel de seda y se ponía como material de relleno guata y viruta. Para las esquinas de los marcos se construían unas almohadillas de papel rellenas de paja. Generalmente los cuadros iban embalados con sus marcos, porque estos les protegían. Si no los tenían, se ponía un suplemento de madera que hacía las veces de marco.

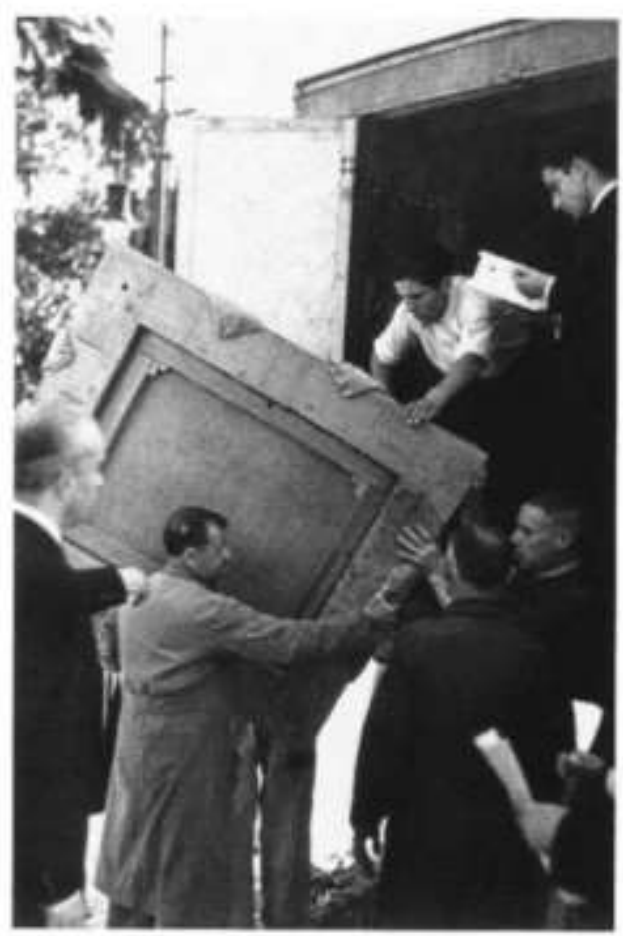

Ángel Macarrón durante la descarga de los cuadros procedentes de Ginebra en el Museo del Prado. Colección fotográfica Santos Yubero. Comunidad de Madrid. 
Al acabar la guerra acompañé a mi tío Juan a Ginebra para traer las obras que estaban allí expuestas. Tenía 18 años y fue mi lanzamiento para empezar a trabajar. Habían prorrogado la exposición y nos marchamos para Suiza en septiembre. Se usaron los mismos embalajes que llevaron a la ida, excepto algunos que habían desaparecido durante los trayectos. Los tuvimos que hacer todo en una semana. El regreso de las obras fue en tren, en un momento también terrible porque se había declarado la Segunda Guerra Mundial y ya comenzaban los bombardeos sobre Francia. En varias ocasiones los convoyes tuvieron que salirse a vías muertas para dejar paso a trenes militares.

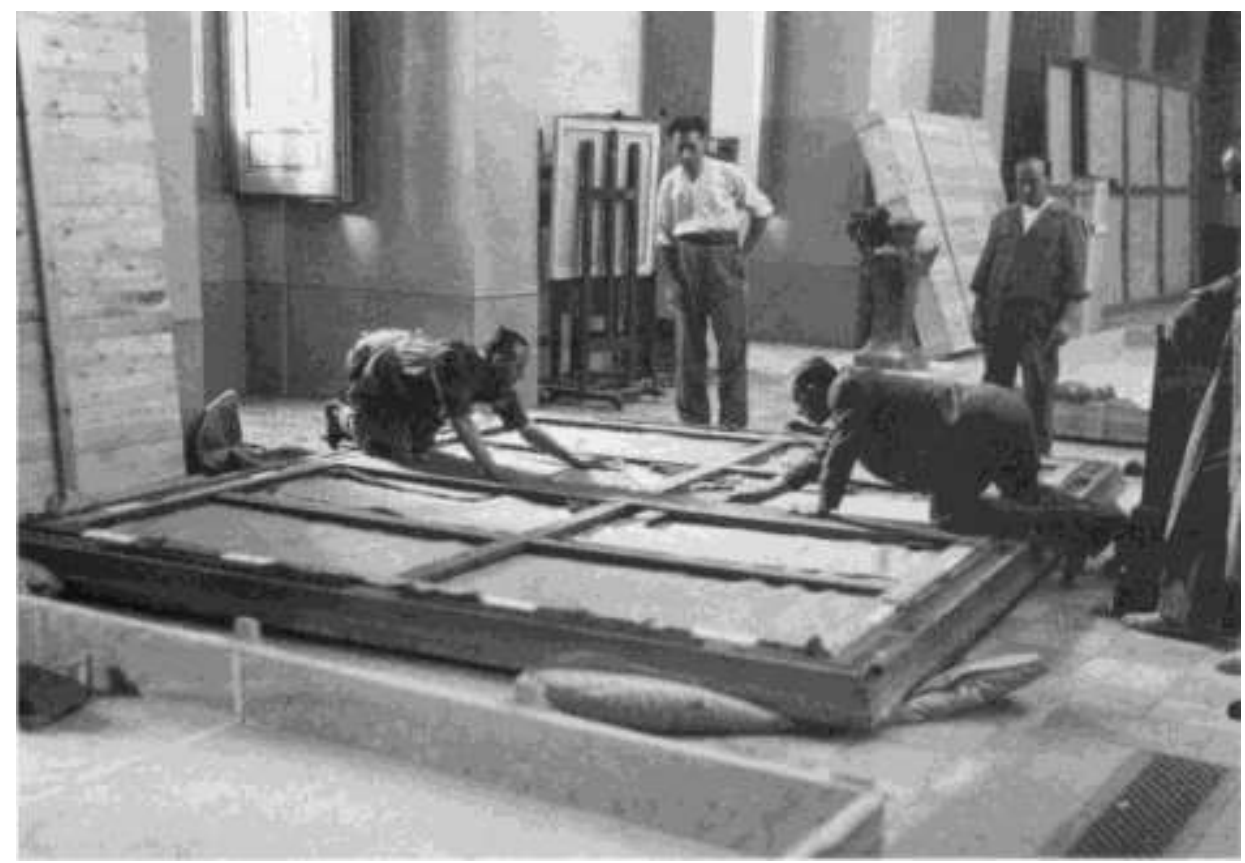

Preparación de embalajes en el Museo del Prado para el traslado de obras a Valencia. Otoño de 1936. Archivo IPCE. Ministerio de Cultura, Educación y Deporte.

\section{En vuestras manos ha estado el embalaje de obras emblemáticas del arte español. Las imágenes de la prensa de la época son muy elocuentes: la dama de Elche, los Zurbaranes de Guadalupe, la Venus del espejo de Velázquez, la Custodia de la catedral de Toledo...}

Después de la guerra trajimos de París a La Dama de Elche, el tesoro de Guarrazar y otras obras. Años más tarde también llevamos a La Dama de Elche desde el Museo del Prado a Elche para una exposición en el año 1961. Después la recogimos y la dejamos en el Museo Arqueológico Nacional, donde está definitivamente. En los años 50 nos encargaron recoger las custodias y ornamentos religiosos para una exposición en Barcelona con motivo del Congreso Eucarístico. Llevamos la custodia de la Catedral de Toledo, la del Ayuntamiento de Madrid, de Salamanca, Zamora... Eran embalajes complicados. Trabajamos toda la familia. En muchos pueblos no nos dejaban sacar los objetos porque pensaban que no se les iba a devolver. Nos pasó con otras exposiciones, y a veces teníamos que pedir escolta de la guardia civil.

Los cuadros de Zurbarán de Guadalupe fueron a Madrid para una exposición sobre el pintor que se iba a realizar en el Casón del Buen Retiro, en 1964, con motivo de su centenario. Primero se iban a restaurar en el ICROA. Se utilizaron para el transporte furgonetas de la guerra. 


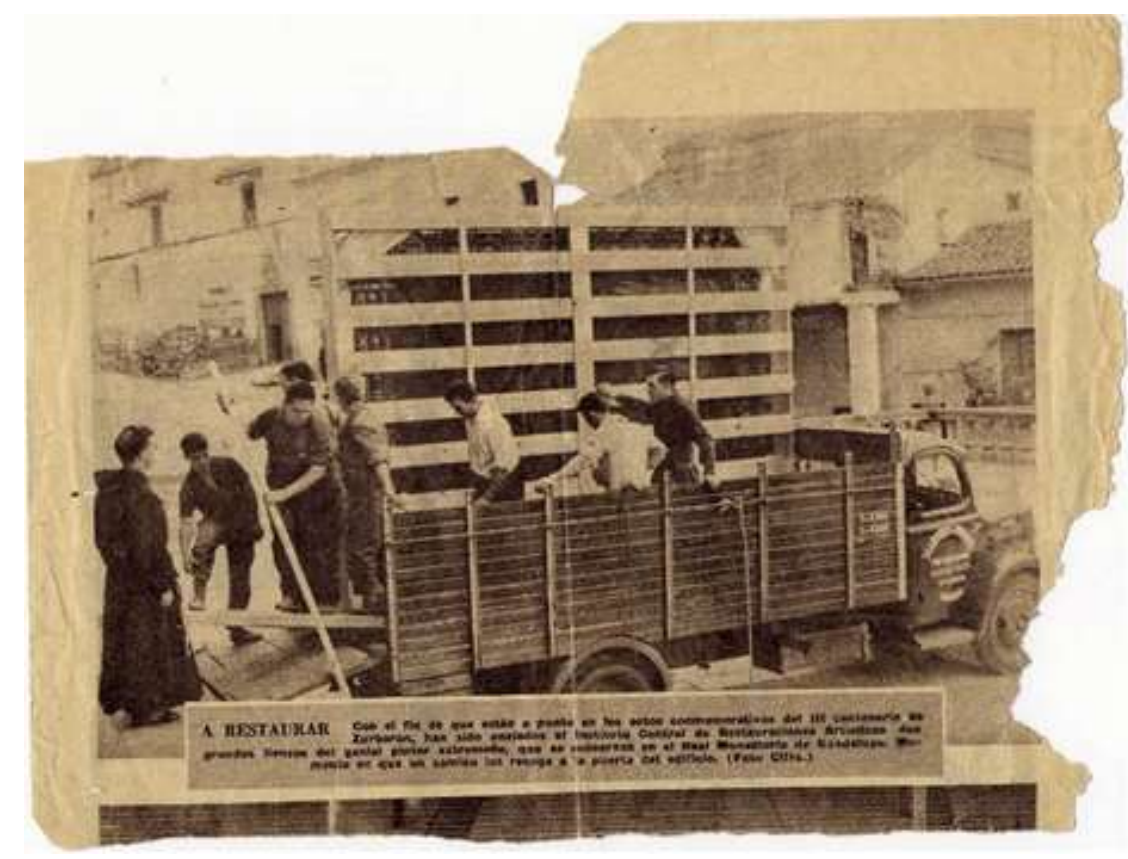

Momento en que el camión recoge dos cuadros de Zurbarán enviados al ICROA para ser restaurados con motivo de los actos conmemorativos del III Centenario del pintor. Foto ABC. 1964.

También transportamos en tres ocasiones a las Majas de Goya, a Londres la primera, a la Royal Academy, luego a la Feria Mundial de Nueva York y la tercera a Tokio, y en las tres hicimos el embalaje. Este consistía en una caja interior para aislar el cuadro con un material secativo y otro mullido para amortiguar. $Y$ tapas atornilladas o con flejes, no con clavos. Se confeccionaban estudiando el volumen de la obra y el peso para la colocación de las cargas. También hicimos el embalaje para La Venus del espejo de Velázquez, que vino en 1961 para una exposición sobre el pintor en Madrid.

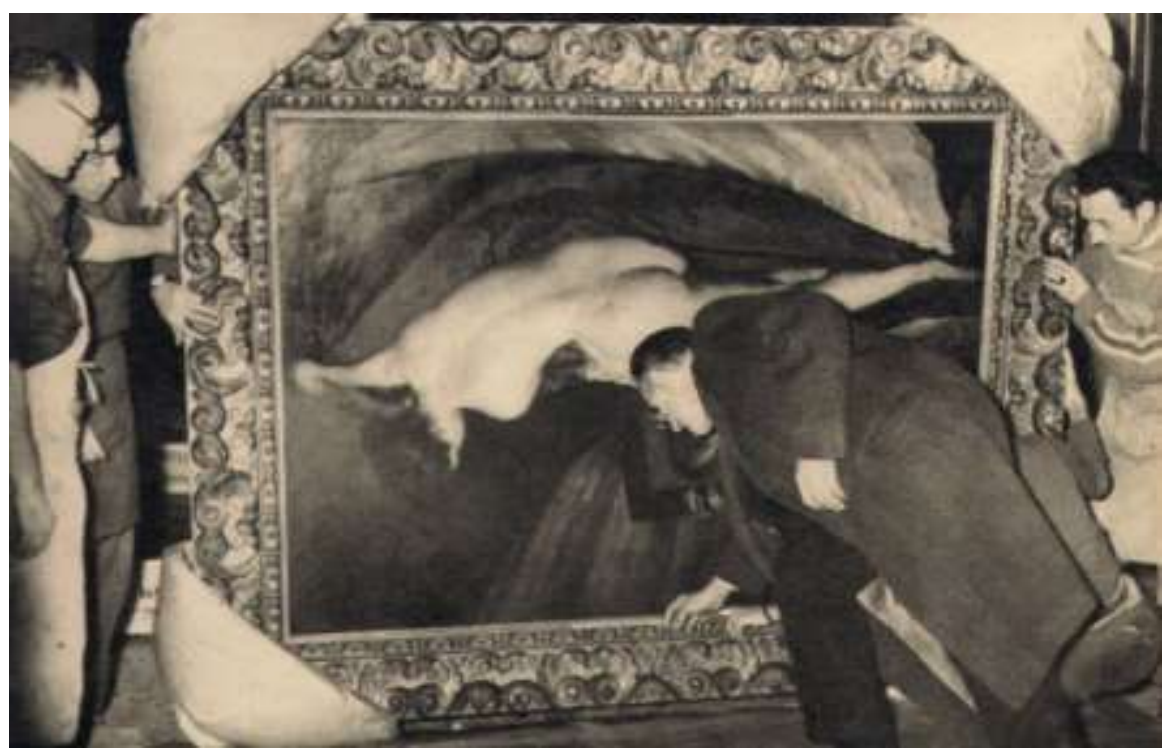

Juan Macarrón dirige el desembalaje del cuadro "La Venus del Espejo" para la exposición de Velázquez, en 1961. 
Constaba de dos cajas forradas en su interior de doble papel embreado (papel-brea-papel) para evitar el efecto de la humedad, del calor y otros factores. En la primera caja la obra quedaba perfectamente fijada a su entorno, con su marco en el caso de pinturas, con almohadillas de papel y viruta en los ángulos o partes que pudieran chocar con las paredes y deteriorarse. Se ponía un encordado sobre los lienzos para evitar los roces de la pintura con otras cosas, y unas sales especiales en el fondo de la caja para conservar la humectación adecuada, estas sales evitaban el posible empañamiento en climas húmedos. La segunda caja era la de fuera, herméticamente cerrada. Debía cargarse, siempre que lo permitiera el espacio, en vertical para evitar que otra carga pudiese caer de golpe sobre la caja. Para prevenir accidentes se procuraba separar en distintos transportes obras muy importantes, por ejemplo, las dos Majas iban en distintos aviones.

Para el embalaje de las piezas del Museo del Cairo, que venían a la exposición del arte faraónico del palacio de Velázquez del Retiro, en 1975, se tuvieron que tomar las medidas de las obras desde fuera de la vitrina porque no dejaban tocar las piezas. Se componía de 25 piezas entre esculturas, sarcófagos, estelas, joyas, terracotas. En el traslado al aeropuerto uno de los camiones chocó con una comitiva de un desfile militar.

Otra especialidad de la casa fue la de instalaciones de museos. Aquí la lista es también larga: Museo español de Arte Contemporáneo, Museo Catedralicio de Plasencia, Museo Sorolla, Museo Cerralbo, Museo Arqueológico Nacional, Casón del Buen Retiro, Museo de Cuenca... para los que hicieron vitrinas y diversos montajes.

Hicimos por ejemplo, en 1978, el montaje en el Museo Arqueológico de Madrid de una reproducción de la tumba de Nefertari que venía del Louvre, por la que me felicitaron expresamente por la corrección del mismo. Otros montajes fueron los de las Bienales de Venecia, el Pabellón de España en el Atomiun de Bruselas, o las pinturas de Antonio Saura para un techo de la Diputación de Huesca. Corríamos numerosos riesgos, como el accidente que tuvieron cuatro empleados en el montaje del Museo Sorolla, pues se cayeron subiendo un cuadro por la escalera, pero afortunadamente no ocurrió nada.

También hice montajes de pinturas murales, como los de Vela Zanetti para la Diputación de Burgos, los de Rafael Pellicer para el hall de entrada de la Fundación Jiménez Díaz, o los de este mismo artista en el techo del Panteón Nacional de Santo Domingo, en la República Dominicana. Allí tuvimos que ingeniarnos otras colas para pegar los lienzos, debido al clima tropical de la isla.
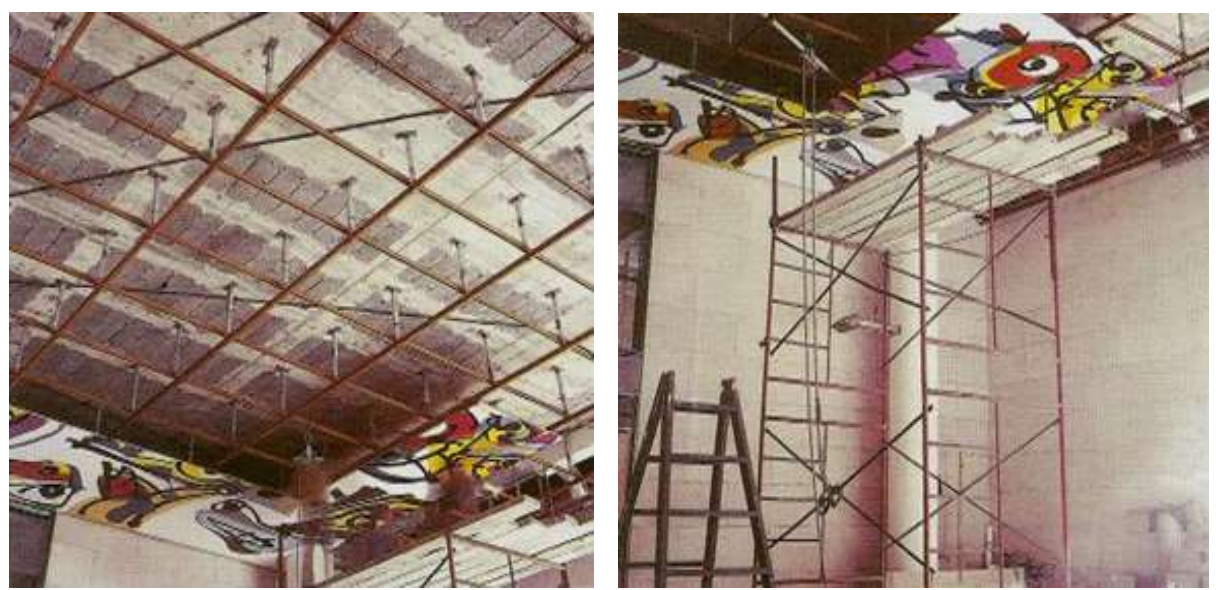

Montaje de las pinturas de Saura en un techo de la Diputación de Huesca. 
Su relación con el mundo del arte le hizo inclinarse por la restauración, algo que también le venía de familia. Su tío abuelo, Alejandro Despierto, fue forrador de Museo del Prado. Ya en el año 57 le hacían una entrevista para una revista en la que daba recomendaciones de conservación preventiva, de limpieza y de otras operaciones de restauración. Nos parece una fortuna para sus hijos, Ana María y Javier, y su nieta Rita, que han continuado con su vocación, tener cerca un a persona como usted, que atesora toda esta sabiduría tradicional sobre el oficio, transmitido de padres a hijos.

Sí, he sido un autodidacta. Compraba cuadros malos en el Rastro para hacer prácticas con ellos. También me ayudó mucho mi paso por la Escuela de Artes y Oficios. Entonces no teníamos los estudios ni los medios que se tienen ahora.

He restaurado muchas obras de gran formato, como la capilla del palacio Real, los murales de la Audiencia de Bilbao y Córdoba, la capilla del palacio de La Granja, pinturas del Palacio de Ríofrío, o las pinturas del salón de Plenos de la Cámara de Diputados del Congreso de Madrid, una bóveda de 50 metros. En esta obra me ayudó mi hija Ana María.

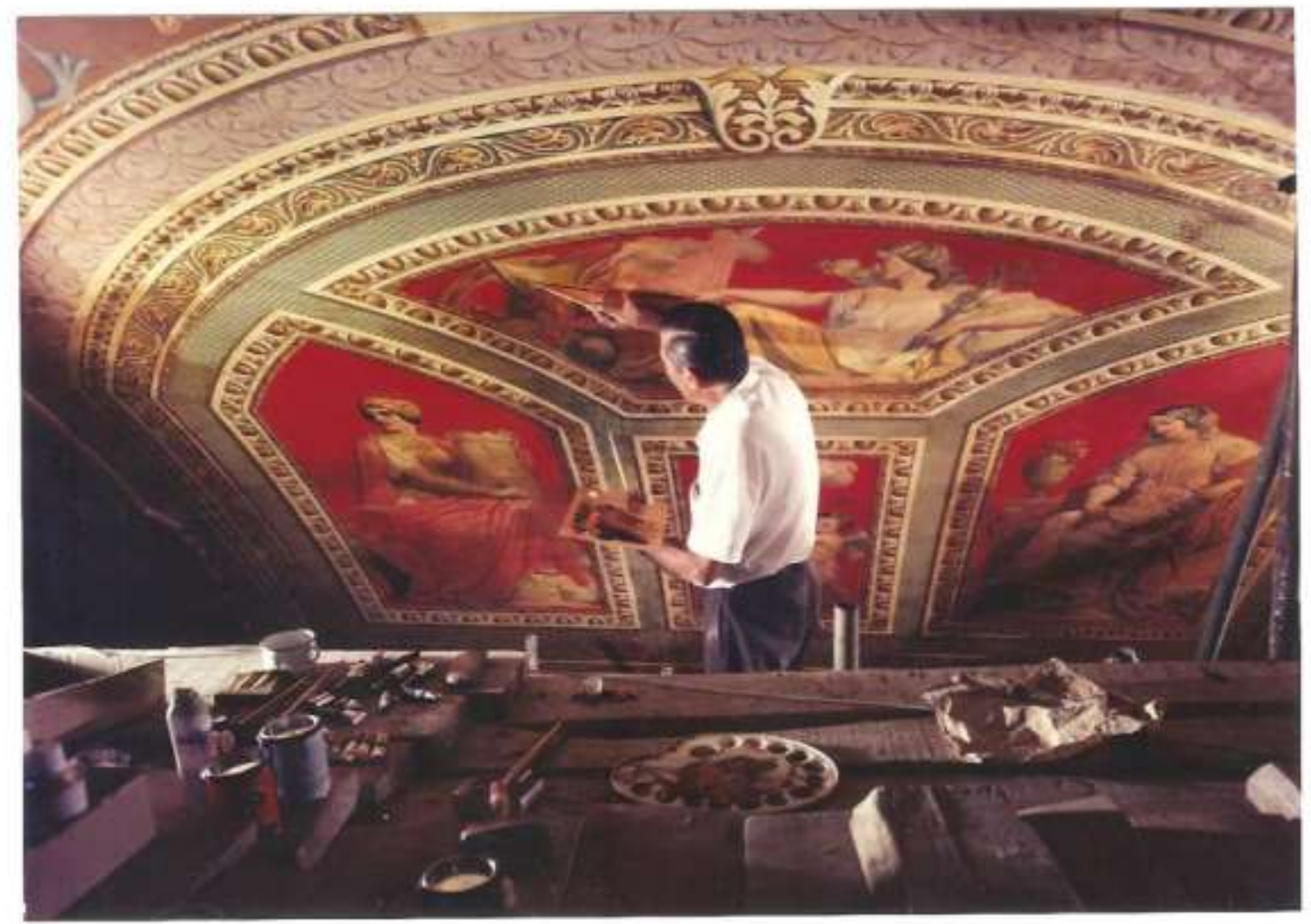

Durante los trabajos de reintegración en las pinturas del techo del Salón de Plenos de la Cámara de Diputados

Finalizamos la entrevista con estas sabias palabras de Ángel Macarrón, que no por parecer muy comunes dejan de ser la clave del éxito en nuestro trabajo:

"Lo que recomiendo siempre es sensatez y no ser demasiado atrevido." 


\section{Bibliografía}

MACARRÓN, A. (2010). Ángel Macarrón. Protector de obras de arte. Inédito, Madrid, 2010.

GARCíA PRADERA, J. (1986). "Casa Macarrón. Sobre el transporte y traslado de obras de arte", Formas Plásticas, n 10, abril.

GÓMEZ SANTOS, M. (1975). "La saga de los Macarrón", La Actualidad Española, (1) n 1226, 7 de julio, (2) no 1227,14 de julio y (3) no 1228,21 de julio.

S/A (1970). "Los Macarrón: famosos mundialmente como restauradores y embaladores de cuadros", EI Alcázar, 21 de enero de 1970.

MACARRÓN, A., MACARRÓN, A.M. y MACARRÓN, M. (2009). "Embalaje y transporte de las obras de artedurante la Guera Civil Española". En Arte protegido: Memoria de la Junta del Tesoro Artístico durante la Guerra civil, Madrid: Ministerio de Cultura.

URKULLU POLO Ma T. (1992). "Investigación del comportamiento de algunos textiles utilizados como soporte de pintura como fuente de documentación a procesos de restauración". Tesis doctoral, Universidad Complutense de Madrid.

VIÑAS TOBOSO, J. (1957). "Entrevista con Ángel Macarrón sobre conservación de cuadros", Arte=Hogar, no 359, Abril.

VV.AA. (2009). Arte protegido: Memoria de la Junta del Tesoro Artístico durante la Guerra civil, Madrid: Ministerio de Cultura.

\section{Rocío Bruquetas Galán}

Instituto del Patrimonio Cultural de España. Secretaría de estado de Cultura

Rocio.bruquetas@mecd.es

\section{Ana Calvo Manuel}

Facultad de Bellas Artes de la UCM

ANACALVOMANUEL@telefonica.net 
Artículos 


\title{
Nuevas aportaciones a la conservación y restauración decimonónica en la Catedral de Sevilla
}

\author{
Ana Galán Pérez
}

Resumen: El presente artículo ofrece nuevas aportaciones a la conservación y restauración decimonónica en la Catedral de Sevilla, reconociendo una diversidad en el origen del corpus normativo y legal de protección de la Catedral, identificando las metodologías en su consecución así como las prioridades en las intervenciones restauradoras, comprobando a su vez la formación de las relaciones institucionales que han generado una red en torno al cabildo, con especial relevancia a los profesionales que se dedicaron a la conservación y restauración.

Palabras clave: Conservación, restauración, historia, Catedral de Sevilla, archivo, gestión patrimonio cultural, siglo XIX.

\section{Novos contributos para a conservação e restauro do século XIX na catedral de Sevilha}

Resumo: O presente artigo oferece novos contributos para a conservação e restauro do século XIX na catedral de Sevilha, reconhecendo uma diversidade na origem do corpus normativo e legal de protecção à catedral. Também foram identificadas as metodologias da sua execução, assim como as prioridades nas intervenções de conservação, comprovando as relações institucionais que criaram uma rede à volta do cabido, com especial relevância aos profissionais que se dedicaram à conservação e restauro.

Palavras-chave: Conservação; restauro; história; catedral e Sevilha; arquivo; gestão; património cultural; século XIX.

\section{Contributions to the nineteenth century conservation and restoration of the Cathedral of Seville}

Abstract: This article offers new contributions about Conservation and Restoration at the Cathedral of Seville, recognizing diversity in the origin of the normative and legal corpus for the protection of the Cathedral, identifying the methodologies to their achievement as well as priorities in the restoration interventions, checking at the same time the formation of institutional relationships that have generated a network around the cabildo, with special relevance to practitioners who were dedicated to the preservation and restoration.

Key words: Conservation, Restoration, History, Seville Cathedral, Archive, Cultural Heritage Management, 19 th Century.

\section{Corpus normativo de protección: Reales Órdenes, comisiones internas y criterios internos y externos}

Una de las primeras normas del siglo XIX que llega a la Catedral de Sevilla es la Real Cédula de 1803: Real Cédula por la que se aprueba y manda observar la Instrucción formada por la Real Academia de la Historia sobre el modo de recoger y conservar los Monumentos Antiguos?. Dicha Cédula es la normativa que se genera debido a la constatación de la pérdida o robo del patrimonio como las ruinas de Itálica, además de la intención de restaurarlos y conservarlos en el mejor estado posible. Este término "recoger" nos acerca a un procedimiento de inventario y catalogación por el que el 
Real Decreto se constituye por su precisión y profundidad, un primer intento catalográfico tal y como señala González-Varas (1999: 173-183). El cabildo catedralicio es agente responsable, necesario ejecutor de dicha norma y por ello responsable de la conservación de la colección catedralicia, pues se establece "la obligatoriedad de que dichas normas se lleven a cabo por parte de M.RR. Arzobispos, RR. Obispos y demás Prelados con jurisdicción vere nullius, al igual que Alcaldes, Chancillerias y Audiencias Reales, Corregidores, Asistente, Intendentes, Gobernadores y Alcaldes Mayores del Reino." Norma, por otra parte, de obligado cumplimiento desde la monarquía vigente ante las pérdidas, robos y otros actos vandálicos reconocidos hacia los objetos artísticos. Subraya, además, la necesidad de una institución como la Real Academia de la Historia, especializando la tarea de preservación de Monumentos y Arqueología, concretamente, la protección de objetos concernientes a la historia, las "cosas antiguas", frente a la otra línea de protección como son los objetos artísticos tutelados por los recién inaugurados Museos de Bellas Artes (de ámbito provincial en su mayoría), Galerías, Pinacotecas y las Academias de Bellas Artes. Es decir, a lo largo del siglo XIX comprobamos la "consideración de dos valores posibles: el histórico y el artístico" (Bolaños 1997:208). Por ello es interesante destacar que se vislumbran ya los antecedentes del concepto de patrimonio cultural, puesto que se hace un llamamiento a preservar lo que se considera propio de todo el estado Español. Carlos IV inaugura con este documento un modelo a seguir que permanecerá vigente todo el siglo XIX.

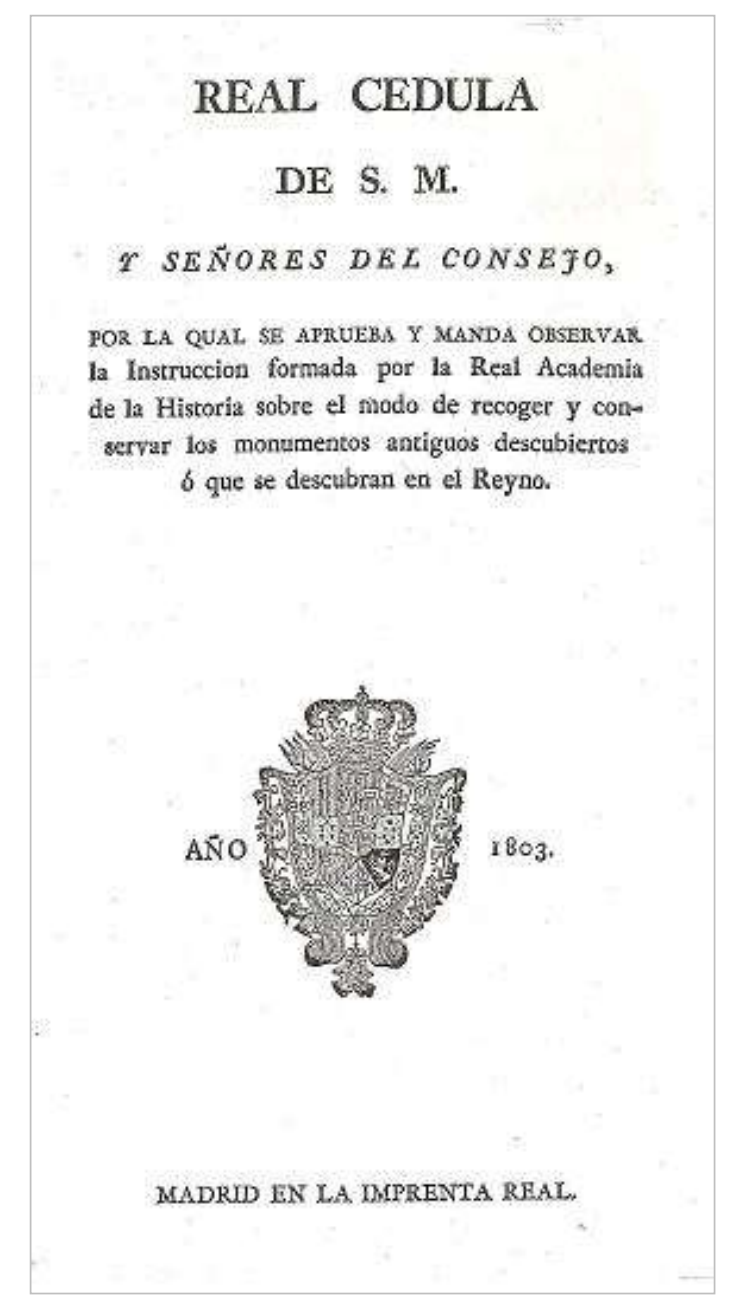

Figura 1. Portada inicial de la Real Cédula de 1803. A.C.S. 
En el año 1826, llega al cabildo catedralicio otra Real Orden y en este caso atiende a la base moral sobre la que se apoya la normativa de protección: Real Orden por la que se nombran revisores por las jurisdicciones Eclesiástica y Civil para evitar la circulación de libros impíos, estampas y pinturas obscenas ${ }^{2}$. Así, sabemos que se estableció una "regla" respecto a criterios éticos y religiosos, existiendo una colaboración patente entre entidades civiles y eclesiásticas, nombrándose una serie de inspectores por las jurisdicciones Eclesiástica y Civil que comprobaban una "normalidad" en cuanto al movimiento e intercambio de libros e imágenes. Así, movimiento y accesibilidad de las obras artísticas como son las estampas y pinturas, son susceptibles de control en la medida en que sus contenidos e iconografía no responden al decoro y la moralidad de ese momento.

Del año 1881, y finalizando la serie de normas de obligado cumplimiento que proceden de la monarquía, la Real Orden transmitida al Deán de la Catedral a través del Director General de Fomento, entidad que traslada la intención de la Restauración de la Catedral por un arquitecto determinado por el mismo monarca: Traslado de una comunicación del Director General de Fomento en la que se comunica la orden del Rey de restauración de la Catedral de Sevilla dirigida por el arquitecto Adolfo Fernández de Casanova ${ }^{3}$. La Catedral de Sevilla se considera monumento artístico, además de templo religioso, en la que su conservación y restauración es responsabilidad de la monarquía, así como la determinación del director de la restauración, esto es, del arquitecto que va a acometer las obras, que en este caso es Adolfo Fernández de Casanova, definiendo y estructurando el perfil de arquitecto que se dedica a la intervención a nivel estructural de la Catedral, siendo así un agente significativo en su protección.

A continuación, destacamos el conjunto de criterios y teorías de conservación y restauración seguidas en la Catedral, pues aportan información sobre las pautas de actuación del cabildo y estructuran un hilo conductor. Comenzaremos atendiendo a los criterios de origen interno: los acuerdos y concordatos, siendo el primero registrado el del año 1861, Concordato entre la Santa Sede y el Gobierno de España. En Documentos sobre la ejecución de concordato entre la Santa Sede y el Gobierno de España en lo relativo a los bienes eclesiásticos pertenecientes al Arzobispado y a la Catedral de Sevilla $a^{4}$, conocemos la gestión o aquellas cuestiones que tienen en consideración los bienes eclesiásticos, entre los que se encuentran los bienes litúrgicos, bajo un criterio de colaboración y atribución de responsabilidades interinstitucional. Años más tarde, en 1882: Arzobispado de Sevilla notifica que se tomen las medidas oportunas para conservar objetos debido al comienzo de obras ${ }^{5}$, se emite una carta en la que se notifica lo siguiente:

"Habiéndose acordado por la Junta creada por el Gobierno de S.M, y para dirigir las obras que se han de practicar en nuestro templo Metropolitano, que se de comienzo a los trabajos en el día 25 del actual, lo participo a ud. con el fin de que pueda adoptar las medidas que estime oportunas así para la conservación de los objetos que existan en esa zona del templo que debe ocupar la obra, como en la manera de ordenar los oficios y celebración de culto."

De esta manera, se informa y orienta al cabildo para que organice la manipulación las obras siguiendo unas pautas de conservación, y así como su nueva ubicación, puesto que no es aconsejable que permanezcan cuando estén las obras. El consejo y notificación de este movimiento, camina junto a la atención y consideración hacia los feligreses que acuden al templo para escuchar la liturgia, puesto que debe adaptar el culto a la nueva situación, tanto por su colección como por aquellos que son el objeto y sentido de generar dicha colección. Dicha recomendación se repite en el mismo año, Salida de correspondencia del Sr. Arzobispo D. Joaquín Lluch y Garriga al Cabildo: inicio de la obra de la Catedral, organización de celebración de culto y 
conservación de los objetos situados en la zona de la obra ${ }^{6}$. Es decir, se está identificando las posibles causas de deterioro en la gestión de los espacios y los objetos para su correcta conservación.

Los criterios conservadores decimonónicos procedentes del propio cabildo catedralicio se recogen también gracias a las comisiones internas. Dichos grupos de personas se constituían para atender asuntos puntuales y el objeto de tal formación era la consecución del éxito de la empresa encomendada. Esta fórmula sugiere lo que consideramos en la actualidad el trabajo transversal, y subraya la consideración de la formación de una red institucional en torno a la colección catedralicia. Pero además, se nos ofrece la perspectiva de una organización interna del cabildo, y constatamos cómo son los individuos que lo componen, los que aportan sus ideas, tendencias y consideraciones. Así, sabemos que en el siglo XIX, dentro del propio cabildo de la Catedral de Sevilla existe una tendencia ilustrada y una tendencia conservadora, tal y como comprobamos en la intención de restauración y los criterios a seguir en el caso de la pintura mural de la Virgen de la Antigua, triunfando finalmente la tendencia ilustrada que apoyaba la intervención de conservación. Este caso del año 1777 sienta los precedentes en cuanto a la generación de comisiones internas como una pauta de trabajo, en este caso formada por el presidente de la capilla de la Antigua y por el Mayordomo de Fábrica y que se establecían tras una alerta en cuanto al estado de conservación de la Virgen de la Antigua (Serrera 1990:171-177), acontecimiento que tuvo su reflejo también en el siglo XIX y por ello resulta imprescindible nombrar a José Escacena y Diéguez, restaurador de la Virgen de la Antigua, quien llevó a cabo la intervención después de que el cabildo desestimara el ofrecimiento del pintor y restaurador Juan Oliva. El cabildo otorgó a José Escacena el título de "Restaurador de los cuadros de la Catedral"7, que antes había desempeñado Manuel Lucena (Serrera, 1987). Finalmente, y tras lo que podemos considerar precedentes del siglo XIX, en 1875 comprobamos la creación de comisiones de trabajo para tratar aspectos relacionados con la colección catedralicia a través de la Carpeta de la Comisión de Restauración de Murillo 8 .

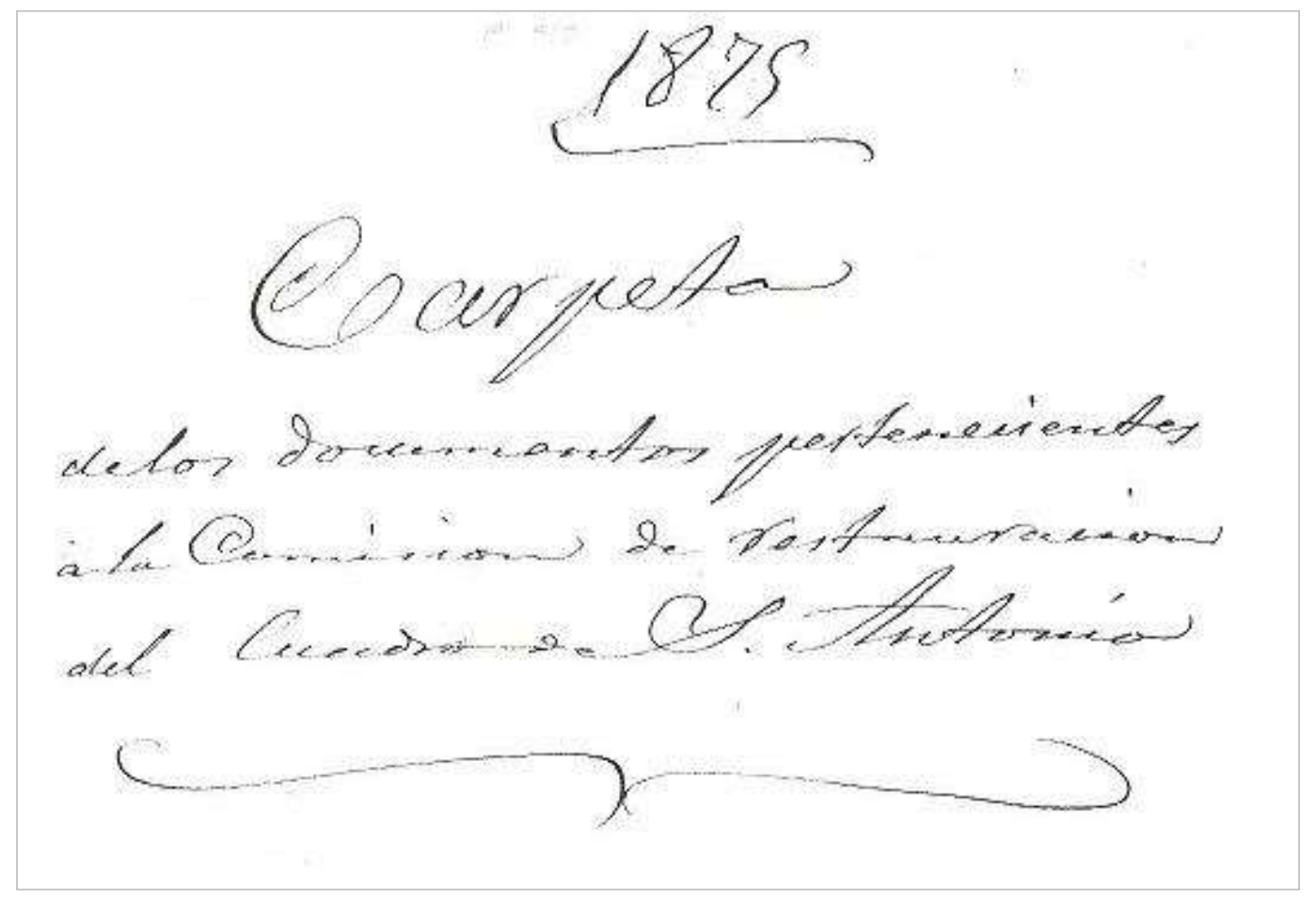

Figura 2. Primera página de la Carpeta de la Comisión de Restauración. A.C.S. 
En todo este corpus normativo de conservación, cabe destacar el peso que han tenido los criterios procedentes de agentes externos íntimamente relacionados con las decisiones del cabildo respecto a su colección, es decir, instituciones locales y estatales con autoridad en materia de objetos muebles constitutivos de colecciones, su conservación y difusión. Una fecha significativa es el año 1881, por el cual la Comisión de Monumentos históricos y Artístico de Sevilla se pronuncia sobre las actuaciones futuras en la Catedral ${ }^{9}$. La orden de la Dirección General de Instrucción Pública que llega a la Comisión de Monumentos a través del Gobernador Civil de la Provincia. Comisión de Monumentos históricos y Artísticos de la provincia de Sevilla, sobre las obras de la Catedral ${ }^{16}$. Así, se informa al Deán y se le solicita respuesta con el fin de reunirse para informar a esta comisión:

"(...) y teniendo en cuenta que es uno de los monumentos más preciados de la nación, solicita a la Comisión de Monumentos que realice un seguimiento para asegurarse que se cumple la normativa y la reglamentación vigente de las Comisiones." "(...) Le recuerda la potestad que tienen las Comisiones de Monumentos, de detener las obras que adulteren el carácter histórico y artístico de los edificios públicos."

Las Comisiones de Monumentos marcarán la pauta conservadora, como también de los criterios de restauración arquitectónica imperante a finales del siglo XIX, y que influirán en la propia restauración de la Catedral comenzada por Adolfo Fernández Casanova en 1881, seguidor del arquitecto Juan de Madrazo y Küntz, y éste a su vez del francés Viollet Le Duc, arquitecto restaurador de Nôtre Dame de París. Precisamente, es este último quien establece las doctrinas de la "restauración en estilo" en el siglo XIX (Morales, 1996). Surge en este momento de tendencia en estilo, la Comisión de Monumentos Históricos y Artísticos de Sevilla y por ello defiende que "no se adulteren el carácter histórico y artístico de los edificios públicos". Sobre las personas que forman parte de la Comisión, en el presente expediente comunica que siguiendo el artículo 21 de la Regla $3^{a}$ del Reglamento de las Comisiones Provinciales de Monumentos, "se nombra a D. Leoncio Baglietto y D. Ángel Ayala, para que practiquen el reconocimiento facultativo y arqueológico de la portada que va terminarse y restaurarse." Solicita, además, a modo de programación que determine el día y hora para que tales personas puedan llevar a cabo la inspección y se subraya la obligatoriedad que "bajo ningún concepto dejen de cumplirse las disposiciones", siendo de información urgente si se ha tenido en cuenta el Reglamento, para requerir notificación al respecto.

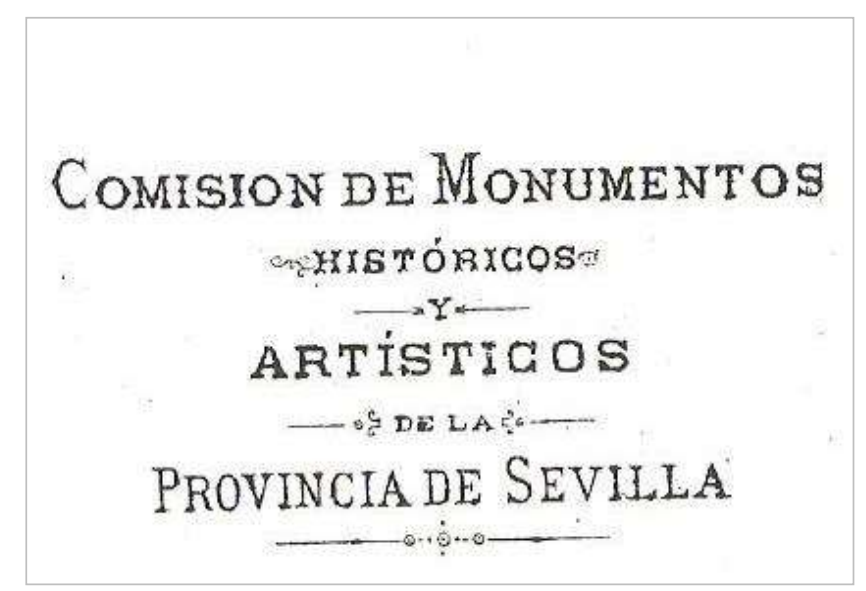

Figura 3. Membrete de correspondencia de la Comisión de Monumentos Históricos y artísticos de la provincia de Sevilla, 1898. A.C.S. 


\section{Conservación preventiva e intervención restauradora en la Catedral}

A finales del siglo XIX, la rehabilitación de la estructura de la Catedral de Sevilla queda patente en los informes, proyectos y memorias, aludiendo tanto a los procedimientos, como a los costes económicos y los recursos humanos. Así, continente vinculado con el contenido, Catedral y colección, forman una sola unidad, resultando clave distinguir y agrupar aquellos elementos de deterioro del patrimonio artístico mueble, entre los que camina intrínseco el devenir del propio edificio y sus restauraciones, así como los medios de control ideados por el Cabildo. Asimismo, en las intervenciones en la colección catedralicia distinguimos dos tipos de actuaciones: las relacionadas con la conservación preventiva, tras las cuales está mucho más presente el Cabildo y los agentes sociales; y las actuaciones restauradoras heterogéneas, pues se aplican según la tipología y naturaleza de los bienes muebles, por su finalidad y la categoría otorgada.

En dichas actuaciones conservadoras son fundamentales las iniciativas de cooperación y relación institucional, verdadero punto de inflexión e inicio en los precedentes hacia la gestión del patrimonio cultural, estudiando las sinergias y las actuaciones de calidad y sostenibilidad entre los distintos agentes que a lo largo del siglo XIX consideraron propia a la Catedral, otorgándole de esta manera su consideración patrimonial (Galán 2012: 315-322).

De 1881 a 1900 se lleva a cabo una restauración integral y sistemática a nivel estructural en la Catedral de Sevilla, realizada por el arquitecto Adolfo Fernández Casanova (González-Varas 1994: 242) que tuvo su motivo en la caída y destrucción del cimborrio por el que se perdieron además las bóvedas adyacentes. Sabemos que provocaron múltiples daños en el órgano, y podemos imaginar la nube de polvo que se generaría sobre los bienes muebles con la consecuente degradación. Así, en 1883, el arquitecto se pronuncia e informa con: "la Dirección facultativa de las obras de Restauración de la Catedral comunica la finalización de la obra en el tramo del coro $^{11}$ y en 1884 , de la misma mano se emite un informe: Dirección de las obras de Restauración de la Catedral' ${ }^{12}$. En este notifica las actuaciones realizadas y se refiere a las medidas de seguridad y prevención en los siguientes términos:
"Terminados ya los apeos y encimbrados relativos al pilar ruinoso del trazo sur del crucero de nuestra grandiosa Catedral, continuará con el corte del este apoyo. Ud. comprenderá perfectamente cuán arriesgadísimos son los trabajos necesarios para dejar colgadas cuatro bóvedas que a más de hallarse ya tan resentidas, pertenecen al más gigantesco Templo de la Edad Media en Europa. Estas circunstancias me obligan a rogar a ud. se digne disponer la suspensión temporal del culto en la región central y en la banda sur de nuestra Basílica y únicamente podrán utilizarse las Capillas de la cabecera y del costado norte, en el caso de no ocurrir complicaciones en los trabajos de desmonte del repetido pilar. Sevilla, 25 de noviembre de 1887".

Finalmente, destacamos la renuncia del propio arquitecto director de las obras de restauración, comprobando que el protocolo de relaciones institucionales de tal perfil de ArquitectoRestaurador con el de la entidad contratante es de tal calibre, que queda recogido en expedientes como el del año 1888: Traslado de una comunicación del Ministro de Fomento en la que se dice aceptar la renuncia del Arquitecto de la Catedral Adolfo Fernández Casanova ${ }^{13}$. 


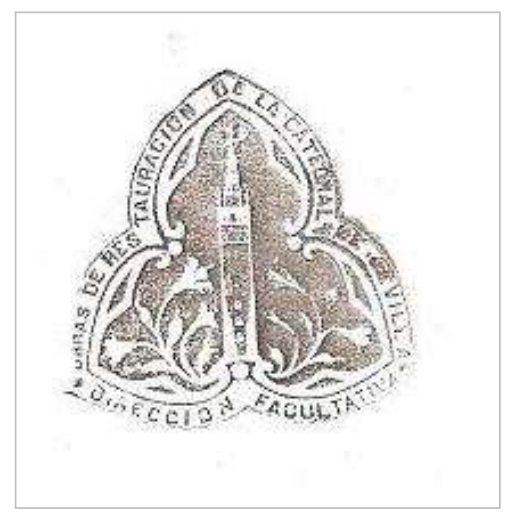

Figura 4. Sello de la Carta emitida por el Arquitecto Adolfo Fernández de Casanova al Cabildo de la Catedral en 1884, respecto a los informes de Conservación de la fábrica del Templo.

Resulta significativo cómo un año anterior al derrumbe, en 1880 , se solicitó un informe del estado de conservación ${ }^{14}$, a dos arquitectos que posteriormente no intervinieron en la obra: Informe elaborado por D. Manuel Portillo y D. Juan Talavera, arquitectos, sobre las obras de reparación de la Catedra ${ }^{15}$. Se trata de una inspección sobre el estado de conservación estructural de la Catedral de Sevilla, identificando causas de degradación, y es sumamente interesante cómo los arquitectos lo exponen.

En una primera presentación del informe, aluden a la belleza e importancia que la Catedral tiene a nivel internacional. El "mundo entero" está interesado en su conservación: "nuestra patria no puede cometer que por abandono se deteriore una de las joyas más valiosas de la España Monumental y Artística".

Señalado el significado y relevancia de la Catedral como entidad patrimonial supraestatal, el informe reconoce dos tipos de intervenciones, las reparaciones ordinarias, y obras accidentales a través de las cuales se especifican las causas de deterioro. Estas son, por una parte constructivas esto es, reconocimiento de mala piedra, por otra las antropogénicas derivadas de las malas reparaciones, y finalmente las climáticas que se traducen en vegetación por exceso de agua. Dice así:

"Dentro de las reparaciones ordinarias está la revisión en los tejados de las algas y plantas parasitarias que crecen por la humedad. Provocan filtraciones y deterioro. Para evitarlo, debe haber una cuadrilla de operarios que eliminen los vegetales y apliquen lechadas de cal para evitar la proliferación de plantas. Este trabajo se califica en 10.000 pesetas anuales."[...] "En el segundo género de reparación, se refiere a la seguridad y estabilidad del templo. Varias agujas de terminación de los machones por la oxidación de su alma de hierro, se han abierto en sentido vertical amenazando con desplomarse sorbe las azoteas" [...] "También en las uniones de los arcos torales con las bóvedas hay grietas producidas por asientos que exigen el pronto establecimiento de la tablazón y tanto las ventanas como las cresterías y antepechos han experimentado deterioros." [...] "Lo más grave es la reparación de la bóveda tallada que forma el crucero de la nave de San Pedro, y la del machón que está adosada a la capilla de la Concepción en el Coro. Debido a las filtraciones y a la mala calidad de la piedra, ha necesitado refuerzos en distintas épocas que al colocarse mal son la causa principal de su mal estado. Oxidación del hierro colocado a modo de planchas y grapas". 
Hemos observado que los arquitectos han efectuado lo que hoy denominamos "examen de los bienes culturales" a través de una inspección ocular u organoléptica sobre el estado de conservación. Finalmente, el informe refleja sus particularidades como templo cristiano "sentimiento religioso", pero sobre todo como monumento histórico artístico.

Sigamos con la participación de la sociedad en los procesos de conservación y restauración. El acontecimiento de la destrucción parcial de la Catedral, movilizó a agentes sociales y culturales, la administración pública y entidades políticas, como comprobamos en 1881, Comisión de Monumentos Históricos y Artísticos de la Provincia de Sevilla, sobre las obras de la Catedral ${ }^{16}$. Del año de 1888 resulta interesante por la cantidad de donaciones que se reciben para restaurar el cimborrio de la Catedral, como La Alcaldía de Sevilla ofrece recursos para la reparación de la Catedra ${ }^{17}$, Es la entidad local competente, el Ayuntamiento de la capital bética, el que interviene en primera instancia. Posteriormente recogemos, el Comunicado del Arzobispado de Granada de la creación de una Junta para recabar recursos económicos para la restauración de la Catedral de Sevilla tras la caída de su Cimborrio ${ }^{18}$. Tratándose en este caso, de una entidad eclesiástica.

También en ese mismo año de 1888 se traslada una Carta del Ministerio de Fomento donde se da cuenta del acuerdo tomado en Consejo de Ministros para otorgar ayuda económica a la reparación de la Catedra $l^{19}$ y finalmente también en el mismo año, El Gobierno Civil manifiesta el deseo de contribuir a la reparación de la Catedra ${ }^{2 C}$. Y un año más tarde, 1898 sigue el interés por parte del contexto político, Diputados a Cortes de Estepa, Aracena y Sevilla se dirigen al Deán de la Catedra ${ }^{21}$, que en aquel momento, era D. Francisco Bermúdez Cañas, para ofrecer su intención y sus recursos económicos para la conservación y restauración de la Catedral. Se trata de un conjunto de tres cartas por las que tres Diputados a Cortes se ofrecen al Cabildo. La primera de ellas, es del Diputado a Cortes por Estepa, en la que responde "al agradecimiento del cabildo por las gestiones realizadas en beneficio de las obras de nuestra Basílica, bajo el cumplimiento de católico y sevillano, amante de las glorias religiosas de este país. Firmado en Sevilla 27/08/1898".

La segunda de ellas es del Diputado a Cortes por Aracena, quien responde a la "atenta comunicación del Cabildo con motivo de las gestiones en los cuerpos colegisladores para obtener a favor de las obras de nuestra hermosa Basílica, la cesión por el Estado del importe del maderamen y demás objetos que sienten en la misma, a terminar la restauración del monumento artístico más hermoso de los templos católicos. Como hijo de Sevilla debe coadyudar a tales deberes. Firmado Luís Palomo, Sevilla 3 de agosto de 1898".

Finalmente, el Diputado a Cortes por Sevilla, ofrece "toda la cooperación que aun cuando modesta es decidida para todo lo relacionado con el hermoso tempo justo y legítimo orgullo de cuantos nacieron en esta ciudad". Nombra una Ley de venta de maderas en beneficio de las obras impulsada especialmente el actual Ministro de Fomento, don Germán Gamazo. Firmado en Sevilla a 6/8/1898. En este contexto de protocolo político, todos han emitido una carta de agradecimiento, con frases afectuosas como indican en las tres situaciones. Los tres afirman que se ven con la responsabilidad de ello, por ser hijos de la ciudad de Sevilla y servir al cabildo.

No sólo es el ámbito político o administrativo el que se preocupa por la conservación de la Catedral. Otros agentes aparecen en escena el mismo año de 1888, como La Real Maestranza de Caballería hace una donación económica para las obras de la Catedral22. Pero mucho más significativo es el expediente por el cual sabemos los vínculos entre instituciones y el sistema de acceso de los museos al público, como es el documento: La Academia de Bellas Artes de Sevilla comunica que su Patronato ha decidido comenzar a cobrar entrada al Museo y destinar ese dinero a las 
obras de reparación de la Catedral por la caída del cimborrio ${ }^{23}$. Comprendemos entonces, que un hecho como la urgencia en la salvaguarda de la Catedral puso en marcha todo un engranaje institucional no sólo político, sino cultural, y por el cual nos constan interesantes documentos, entre ellos los proyectos de rehabilitación arquitectónica, que hoy nos ayudan a hilar la historia de la conservación y restauración en el siglo XIX.

Frente a la protección patrimonial que hemos apuntado en párrafos anteriores, asistimos en el siglo XIX a un cambio de gustos artísticos que deriva en la destrucción de bienes eclesiásticos, y que defendidas en informes de conservación estructural, registran una intención de sustitución no por razones de seguridad, sino simplemente por estética. Así, en el año 1824 el expediente, Restauración de la Capilla del Sagrario ${ }^{24}$, recoge las dos cartas que tratan el examen del arquitecto Silvestre Pérez del templo del Sagrario en la Catedral de Sevilla. Resultan significativas por varios aspectos que analizamos a continuación. El arquitecto Silvestre Pérez comunica en una primera carta, que ya ha realizado las observaciones en el exterior del templo, pero en lo que respecta a su interior dice lo siguiente:

"Por el interior no se ha podido reconocer, porque lo impide la prodigiosa extensión del retablo mayor y sus remates que cubren el arco, no sólo por su paramento, sino también por su arquivolta, elevándose a cubrir gran parte de la media naranja; y si no se hace el benéfico sacrificio de desmantelarlo nunca se reconocerá ni podrá decirse el estado de solidez en el que se halla por esta parte principal. Sevilla, 17 de Marzo de 1824."

En una segunda carta, apunta:

"No puedo dejar de manifestar mi agradecimiento al Ilmo. Cabildo por la deferencia que tuvo a mi indicación (...) mandando que desaparezca del templo un retablo que ha sido ejemplo de las extravagancias del arte, y acordando su reforma (del templo) del modo más regular. Sevilla, 4 de Mayo de 1824".

Comunica, de esta manera, que es necesario desmontar el retablo mayor para saber cómo es el estado de conservación de la estructura arquitectónica de la Catedral. Es decir, estamos siendo testigos de cómo en la propuesta de un arquitecto que está inspeccionando el estado de conservación de la Catedral, sugiere que se desmantele parte de la colección catedralicia que además tiene una función litúrgica. Este retablo, era un retablo barroco de Jerónimo Balbás, y tenemos constancia que tras su destrucción se colocó un templete neoclásico, probablemente del mismo arquitecto Silvestre Pérez, y posteriormente se colocó el retablo de la Hermandad de los Vizcaínos.

En definitiva, se justifica la eliminación del retablo barroco por gusto y estilo, y no por peligro de ruina que fue el motivo por el cual se realizó la inspección de conservación (Serrera 1998:135, citado en Bravo 2010:326). Comprobamos cómo en el siglo XIX las ideas estéticas contribuyen a la conservación y determinan qué elementos son susceptibles de ser eliminados.

Respecto a la conservación y restauración de su colección catedralicia, el Cabildo va a mostrar un espíritu ilustrado. Sus intervenciones siguen y reflejan el desarrollo de la disciplina conservadora y restauradora en el entorno del museo y de las academias, dando lugar incluso a debates interinstitucionales sobre qué academia dispone de los profesionales más adecuados para ejecutar dichas restauraciones, como es el caso en torno a la restauración de La visión de San Antonio de Padua de Murillo, entre la Real Academia de San Fernando y la Real Academia de Santa Isabel de Hungría ${ }^{25}$. La carpeta de la comisión de restauración del cuadro de "La Visión de San Antonio" de 
Murillo, en 1875. Documentos pertenecientes a la Comisión de Restauración del Cuadro de San Antonio de Murillo robado en la Catedral de Sevilla ${ }^{26}$, está formada por veintiuna cartas manuscritas, y le complementa otro grupo de documentos recogidos en el expediente Recuperación de un lienzo de Murillo que había sido robado ${ }^{27}$. La intervención restauradora ha sido ampliamente estudiada (Cortegana 1957; Rallo 1995; Ruiz de Lacanal 1999; Vicente 2010), sin embargo hemos considerado interesante apuntar que a través de la sistematización y protocolos al respecto de los sucesos, así como incluir las instituciones y los nombres propios el Cabildo distingue entre su colección de unas obras respecto a otras, haciéndolas susceptibles de ser conservadas y restauradas.

En esta línea es interesante la contraposición que se genera entre el interés de seleccionar un perfil académico para restaurar un cuadro de Murillo, frente a las intervenciones de conservación y restauración de bienes como el grupo de instrumentos musicales y de medida, que pese a recoger el interés por su salvaguarda, dichas intervenciones las llevan a cabo artesanos que revisan, reparan, y ponen en funcionamiento los mismos, identificando el rasgo determinante: su uso continuado cuya función es constituirse como soporte y ayuda en la misión evangelizadora del templo.

Es la finalidad litúrgica y no otra, por la que este grupo de bienes muebles han sido construidos, pero no por ello se olvida la intención artística en la construcción de cajas esculpidas y elementos ornamentales. De 1884, nos consta el primer expediente: Presupuesto del coste económico de la reparación del Órgano de la Catedral ${ }^{28}$. Observamos cómo el cabildo solicita de manera formal a agentes individuales, profesionales especializados, una estimación económica de lo que supone la restauración. Unos años más tarde, en 1888 , se trata la construcción de un nuevo órgano, en el expediente sobre la: Memoria del Proyecto para la construcción de un Órgano en la lglesia del Sagrario $^{29}$. Esta recopilación de información en forma de memoria, reconoce la trascendencia que supone disponer de dicho instrumento musical con función litúrgica. Finalmente en 1891, sobre el mantenimiento del Órgano de la Catedral.: Informe de la Comisión encargada de supervisar la terminación y el funcionamiento del Órgano de la Catedra ${ }^{36}$. Podemos comprobar su peso, puesto que se ha generado una comisión interna de trabajo para hacer un seguimiento de su funcionamiento.

Una vez más asistimos a la generación de comisiones internas en torno a la conservación y restauración de su colección catedralicia, quien solicita la reparación, construcción y puesta a punto de sus órganos y de profesionales que notifican, a su vez, de sus actuaciones.

Respecto a las intervenciones en instrumentos de medida, debemos hacer mención a la reparación y reforma del cuerpo de reloj que Fernández Casanova realiza en 1886, cuando está restaurando la Giralda de la Catedral de Sevilla. Este reloj sabemos que fue encargado por el Cabildo a Fray José Cordero, lego franciscano del Puerto de Santa María. En el proceso de restauración sabemos que se intervino en el reloj:

"Se procedió a desarmar, bruñir, y volver a montar la maquinaria del reloj y las transmisiones de movimiento a la campana y a la esfera situada en el cuerpo de campanas. Se fabricó una rueda de engrane de bronce y dos pescantes con sus soportes correspondientes, se doró y pintó la caja y se colocó un cierre de hierro con cristales." (Jiménez 1986:124, citado en González-Varas 1994: 298).

Precisamente en este año de 1866, hemos identificado el presente expediente: Gobierno de la Provincia, arreglo de Relojes de la Catedral ${ }^{31}$, interviene un agente colectivo socioeconómico de la 
administración provincial, una entidad externa a la Catedral en la conservación y restauración de estos instrumentos de medida ${ }^{32}$.

Tal y como hemos podido comprobar a través del estudio de las comisiones, los criterios e informes, obtenemos los nombres propios de las personas relacionadas con el devenir de la colección catedralicia, y entre ellos, los nombres de los conservadores y restauradores ${ }^{33}$. Del año 1875, José Rivero, restaurador $1^{\circ}$ del Museo Nacional de Pinturas, se ofrece de manera particular a restaurar el cuadro la Visión de San Antonio de Murillo, quien finalmente fue restaurado por Salvador Martínez Cubells. Unos años más tarde, en 1907, conocemos a José Escacena y Diéguez, restaurador de la Virgen de la Antigua de la Catedral, designado "Restaurador de los cuadros de la Catedral". Anterior a éste lo fue Manuel Lucena, también restaurador identificados ambos en la obra de Serrera (1987). Sin fecha concreta, obtenemos el nombre de Juan Oliva, restaurador, por su ofrecimiento de restaurar la Virgen de la Antigua que fue desestimado a favor de José Escacena.

\section{Conclusiones}

Como conclusión, podemos confirmar el papel y el significado de la Catedral como agente protector y difusor de las artes decimonónicas. Constituida como una institución museística en una red interinstitucional, la Catedral ha sido abanderada en la salvaguarda del patrimonio respecto a las instituciones culturales de su época. Se abre, por tanto, una nueva manera de investigar y sobre la que establecer un futuro método contrastado y válido en la elaboración de Planes de Catedrales, en los que se requiere analizar las sinergias pasadas para proyectar las futuras con éxito, en las que el género epistolar de Archivo se convierte así en una herramienta con una información dinámica de toda una declaración de intereses, pensamientos, decisiones, actuaciones en conservación y restauración tanto de la fábrica como de los bienes que custodia, y no sólo procedentes del órgano gestor principal, el Cabildo, sino que en este intercambio se genera una órbita de agentes externos, instituciones e individuos, que con sus actuaciones están reconociendo y posicionando a la Catedral de Sevilla no sólo como templo religioso sino como institución patrimonial.

\section{Notas}

[1] Procede de la Secretaría de Estado y consta de una carta dirigida al Deán Metropolitano Catedral de Sevilla con fecha del 19 de septiembre de 1827, y documentación Anexa que es la Real Cédula de 6 de julio de 1803. A.C.S. Fondo Capitular. Fondo Histórico General. Num. Leg. 11257. A, № Exp. 20.

[2] A.C.S. Fondo Capitular. Fondo Histórico General. Num. Leg. 11257. A, No Exp. 20

[3] A.C.S. Fondo Capitular. Secretaría. Correspondencia. Num. Leg. 11172, № Exp. 16

[4] A.C.S. Fondo Capitular. Fondo Histórico General. Num. Leg. 11338, № Exp. 5

[5] A.C.S. Fondo Capitular. Secretaría correspondencia. Num. Leg. 11191, № Exp. 10

[6] A.C.S. Fondo Capitular. Secretaria correspondencia, Num. Leg. 11173, No Exp. 6

[7] Viene a subrayar la génesis del perfil del conservador-restaurador en contraposición con el perfil del conservador-arquitecto del cual tenemos numerosas noticias y referencias documentales.

[8] A.C.S. Fondo Capitular. Fondo Histórico General, Num. Leg. 11338, No Exp. 11

[9] A través de la Real Orden de 13 de junio de 1844 se crean las Comisiones de Monumentos Históricos y Artísticos. La comisión de Monumentos de Sevilla se creó el 12 de septiembre de 1844, López, 2010:179. 
[10] A.C.S. Fondo Capitular. Secretaría. Correspondencia Num. Leg. 11172, № Exp. 18

[11] A.C.S. Fondo Capitular. Secretaría. Correspondencia. Num. Leg 11173. № Exp. 15

[12] A.C.S. Fondo Capitular. Secretaría. Correspondencia. Num. Leg 11175. № Exp. 14

[13] A.C.S. Fondo Capitular. Secretaría. Correspondencia. Num. Leg № 11176. Exp. 1

[14] Casanova elaboró una Memoria informativa con un primer reconocimiento de la Catedral previa a la intervención restauradora.

[15] A.C.S. Fondo Capitular. Fondo Histórico General, Num. Leg 11318. № Exp. 22

[16] A.C.S. Fondo Capitular. Secretaría. Correspondencia. Num. Leg 11172. № Exp. 18

[17] A.C.S. Fondo Capitular. Secretaría. Correspondencia. Num. Leg 11176. № Exp. 6

[18] A.C.S. Fondo Capitular. Secretaría. Correspondencia. Num. Leg 11176. № Exp. 5

[19] A.C.S. Fondo Capitular. Secretaría. Correspondencia. Num. Leg 11176. № Exp. 6

[20] A.C.S. Fondo Capitular. Secretaría. Correspondencia. Num. Leg 11176. № Exp. 6

[21] A.C.S. Fondo Capitular. Secretaría. Correspondencia. Num. Leg 11181, № Exp. 5

[22] A.C.S. Fondo Capitular. Secretaría. Correspondencia. Num. Leg 11176. № Exp. 6

[23] A.C.S. Fondo Capitular. Secretaría. Correspondencia. Num. Leg 11176. № Exp. 6

[24] A.C.S. Fondo Capitular. Secretaría. Correspondencia. Num. Leg 11290/3. Diversos

[25] A.C.S. Fondo Capitular. Fondo Histórico General. Num. Leg. 11338. № Exp. 11

[26] A.C.S. Fondo Capitular. Fondo Histórico, 11338, Exp. 11

[27] A.C.S. Secretaría. Correspondencia. 11170. Exp. 19

[28] A.C.S. Fondo Capitular. Secretaría. Correspondencia. Num. Leg 11174. № Exp. 7

[29] A.C.S. Fondo Capitular. Secretaría. Correspondencia. Num. Leg 11176. № Exp. 8

[30] A.C.S. Fondo Capitular. Secretaría. Correspondencia. Num. Leg 11177. № Exp. 8

[31] A.C.S. Fondo Capitular. Secretaría. Correspondencia. Num. Leg 11182. № Exp. 16

[32] Con toda probabilidad se trate del reloj de la Giralda, restaurado en 1866 y comentado anteriormente.

[33] Cabe señalar la contraposición entre los restauradores de pintura que procedían de la Academia, los arquitectos-restauradores de la fábrica catedralicia y finalmente, los restauradores de los bienes muebles, que son considerados como artesanos.

\section{Bibliografía}

CORTEGANA, J (1957). "Restauración del gran cuadro de Murillo: La Visión de San Antonio de Padua”, Archivo Hispalense No 81-82: 107-110.

BRAVO BERNAL, A.M. (2008). El Sagrario, un problema y su historia: estudio Arquitectónico y Documental de la Capilla del Sagrario de la Catedral de Sevilla. Sevilla: Universidad de Sevilla y Fundación Focus-Abengoa.

GALÁN, A. (2012). “El Patrimonio cultural. Una investigación sobre el patrimonio cultural y su gestión en los Archivos de la Catedral de Sevilla", en Actas del V Congreso Grupo Español del IIC Patrimonio cultural. Criterios de calidad en intervenciones. Madrid, GEIIC: 315-322.

GESTOSO Y PÉREZ, J. (1892). Historia y descripción de la Sacristía Mayor de la Catedral de Sevilla y de las preciosidades artísticas que en ella se custodian. Sevilla: Imprenta de la Revista de Tribunales. 
GESTOSO Y PÉREZ, J. (1889). Sevilla Monumental y Artística. Historia y descripción de todos los edificios notables, religiosos y civiles, que existen actualmente en esta ciudad y noticias de preciosidades artísticas y arqueológicas que en ellos se conservan, Sevilla.

GESTOSO Y PÉREZ, J. (1889). Catálogo de las obras que forman la Exposición retrospectiva de la pintura Sevillana. Celebrada en esta ciudad, en virtud del acuerdo de su Excmo. Ayto. durante el mes de abril del presente año de 1896. Sevilla: Tip. de la Región, San Eloy, nº 32.

GÓMEZ DE TERREROS GUARDIOLA. M. del V. (2007). "La Catedral de Sevilla en 1880: Informe de los arquitectos Manuel Portillo y Juan Talavera sobre el estado del edificio", Laboratorio de Arte, 20: 363-372.

GONZÁLEZ-VARAS IBÁÑEZ, I. (1994). La Catedral de Sevilla (1881-1900): El debate sobre la restauración monumental. Sevilla: Diputación de Sevilla.

LAGUNA PAUL, T. (2003). "Transformaciones en la Sacristía Mayor de la Catedral de Sevilla y otras reorganizaciones durante el siglo XIX", separata Catedrales Españolas, Murcia: Universidad de Murcia.

LUQUE CEBALLOS, I. (1996). "La Catedral de Sevilla: ¿Museo o Catedral?", Revista Atrio, № 8/9: 223-232.

RALLO GRUSS, C. (1995). "Memoria de la restauración del San Antonio de Murillo en el Archivo de la Academia de San Fernando", Atrio, no 7:77-93.

RUIZ DE LACANAL RUIZ-MATEOS, Ma D. (1999). El Conservador-Restaurador de Bienes Culturales. Historia de la profesión. Madrid: Síntesis.

SERRERA CONTRERAS, J. (1990). "La Virgen de la Antigua: Informes y restauraciones, Siglo XVIII-XIX", Archivo Hispalense, № 73, 223:171-176.

SERRERA CONTRERAS, J.M. (1999). "Los ideales neoclásicos y la destrucción del Barroco. Ceán Bermúdez y Jerónimo Balbás", Archivo Hispalense n²223: 135-218.

VICENTE RABANAQUE, M. T. (2010). Historia de la Restauración. Del clásico estudio del objeto al sujeto como objeto de estudio, Tesis doctoral inédita. Facultad de Bellas Artes de la Universidad de Valencia.

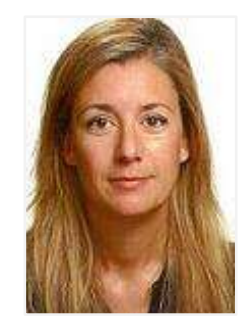

\section{Ana Galán Pérez}

am.gp.mail@gmail.com

Licenciada en Historia del Arte y Doctora en Bellas Artes. Es miembro activo del Grupo de Investigación HUM673 SOS Patrimonio, así como del GE-IIC y participa de la Junta Directiva de ACRE. Especializada en Conservación y Restauración de Bienes Culturales por la Escuela Superior de Barcelona (ESCRBCC) y postgraduada por la Facultad de Bellas Artes de Barcelona. Master en Gestión Cultural, Patrimonio y Museos, ha sido becada por el Museu Maritim de Barcelona y por el SCRBCC, el Servei de Conservacio y Restauracio de la Generalitat de Catalunya. Autora de estudios y artículos relacionados con la conservación y gestión patrimonial en la Historia, y nuevas metodologías de investigación en Archivos Históricos, con especial atención en la perspectiva social del patrimonio cultural.

Artículo recibido el 29/07/2012

Artículo aceptado el 14/04/2013 


\title{
El monumento al General José Gervasio Artigas: la conservación- restauración de escultura conmemorativa en bronce en ambiente urbano
}

\author{
Claudia Frigerio Vidal, Manuel Angel Iglesias Campos
}

\begin{abstract}
Resumen: La conservación del arte público en bronce en medio urbano resulta siempre compleja porque el monumento ha estado, y permanecerá después de la intervención, en unas condiciones ambientales cambiantes y difíciles de controlar. En este trabajo se presenta el procedimiento de trabajo llevado a cabo durante la restauración del Monumento a José Gervasio Artigas en Montevideo, obra cargada de simbolismo para la memoria colectiva de Uruguay, en la que a partir de estudios previos y de análisis SEM-EDX, XRD y endoscopia, se diseñó una intervención que permitió conocer en profundidad la escultura y plantear los trabajos dentro de criterios deontológicos comúnmente aceptados. Pero además, y en parte debido a la importante carga simbólica de la obra, a partir de los datos obtenidos se trabaja actualmente en la planificación de su mantenimiento periódico y el de otras esculturas similares, confirmando la necesidad del conocimiento exhaustivo de cualquier obra para reducir re-intervenciones complejas, invasivas y costosas.
\end{abstract}

Palabras clave: Conservación y restauración, arte público, escultura en bronce, SEM-EDX, XRD, endoscopia, limpieza, mantenimiento.

\section{O monumento ao General José Gervásio Artigas: a conservação e restauro da escultura comemorativa em bronze em ambiente urbano}

Resumo: A conservação de arte pública em bronze em contexto urbano é sempre complexa porque o monumento tem estado e permanece depois da intervenção em condições ambientais variáveis e difíceis de controlar. Neste trabalho apresenta-se a metodologia levada a cabo durante a intervenção de restauro ao monumento a José Gervásio Artigas em Montevideu. A obra, plena de simbolismo para a memória colectiva de Uruguai, foi alvo de estudo prévios e de análises por SEM-EDX, XRD e endoscopia desenhando uma intervenção que permitiu conhecer em profundidade a escultura e desenvolver os trabalhos dentro de critérios deontológicos comummente aceites. Para além disso, e, em parte, devido à importante carga simbólica da obra e a partir dos dados obtidos, actualmente, tem-se trabalhado na planificação da sua manutenção periódica e de outras esculturas semelhantes, confirmando a necessidade do conhecimento exaustivo de qualquer obra para reduzir re-intervenções complexas, invasivas e custosas.

Palavras-chave: Conservação e restauro; arte pública; escultuar em bronze; SEM-EDX, XRD; endoscopia; limpeza; manutenção.

\section{The Monument to General José Gervasio Artigas: conservation-restoration of bronze memorial sculpture in urban environment}

\begin{abstract}
The conservation of metallic public art made in bronze in urban environment is very complex because the monument has been, and will remain after the intervention, in a challenging environment difficult to control. This work presents the methodology used in the restoration of the José Gervasio Artigas Monument, in Montevideo, equestrian sculpture laden with symbolism for the collective memory of Uruguay, based in previous studies and SEM-EDX, XRD and endoscopy analysis, which allowed us to know the monument deeply and to raise the intervention within the commonly accepted ethical standards. Moreover, and in part due to the symbolism of the sculpture, the data obtained from this analysis are being used to raise its regular maintenance, and to other public art sculptures, reaffirming the necessity of a comprehensive knowledge of any artwork to reduce complex re-interventions, invasive and costly.
\end{abstract}

Key words: Conservation-restoration, public art, bronze sculpture, SEM-EDX, XRD, endoscopy, cleaning, maintenance. 


\section{Introducción}

El monumento al General José Gervasio Artigas, prócer de la emancipación americana y precursor de la nacionalidad uruguaya, es una obra de arte público conmemorativo ubicada en Plaza Independencia de Montevideo. Social y culturalmente es una imagen emblemática y representativa de la historia del país y forma parte de su memoria colectiva.

El conjunto, de $17 \mathrm{~m}$ de altura, $10 \mathrm{~m}$ de largo y $7 \mathrm{~m}$ de ancho, está formado por la gran escultura ecuestre en bronce del General -representado con la mirada en alto, vestiduras castrenses de época, espada pegada a la montura, y con las Instrucciones del año XIII en la mano'- que descansa sobre un pedestal aplacado con granito pulido, en el que destacan la inscripción con el apellido del militar y el relieve perimetral de $34 \mathrm{~m}$ de longitud, también en bronce, con escenas del Éxodo del Pueblo Oriental ${ }^{2}$. La obra representa una figura heroica según la concepción clásica y refleja el eclecticismo de finales del XIX y principios del XX en Uruguay, y en general en toda Latinoamérica, donde los valores artísticos se reservaban a un imaginario europeizado y academicista [figura 1].

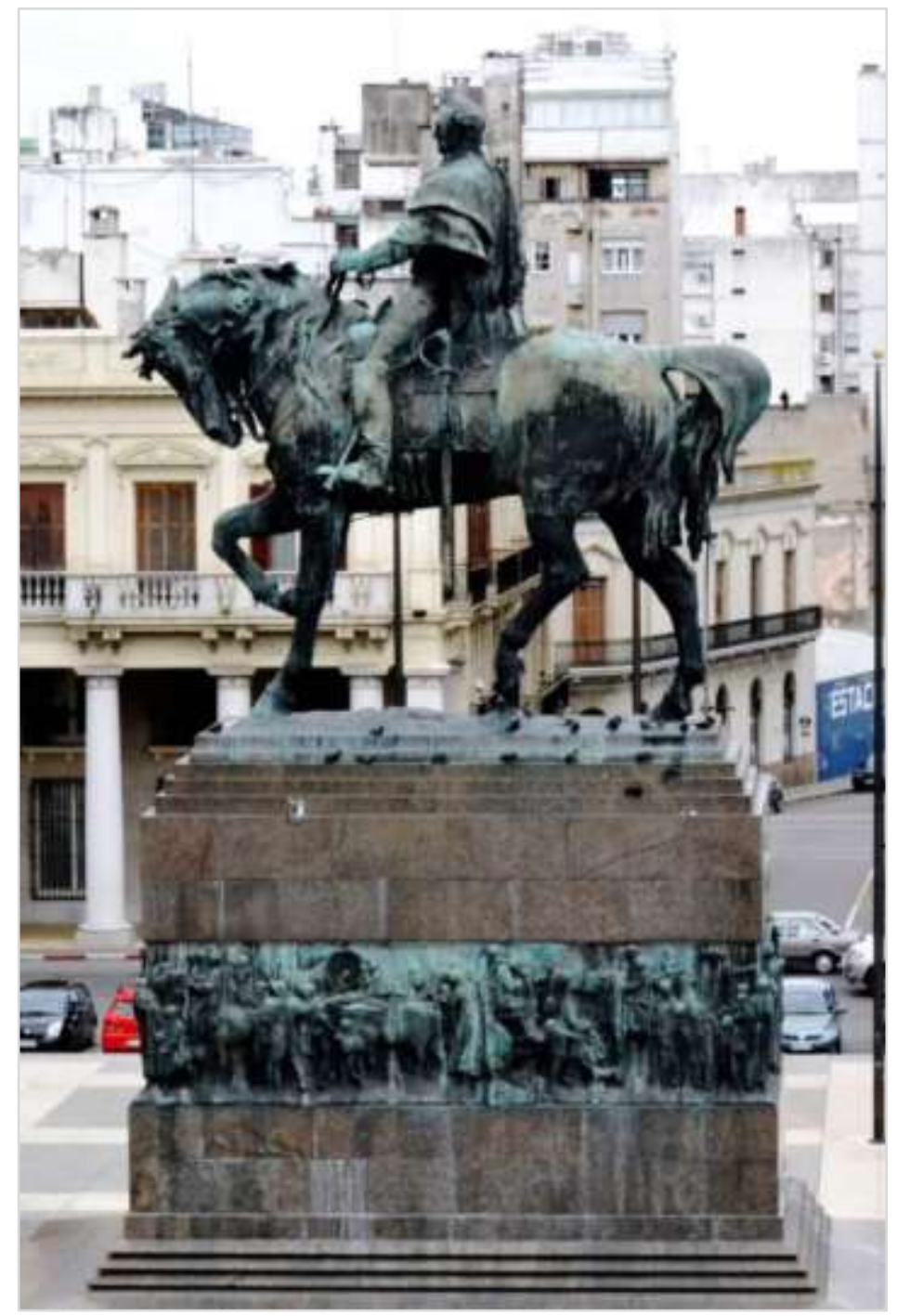

Figura 1. Monumento a José Gervasio Artigas antes de la intervención. @ Jimena Schroeder - Claudia Frigerio. 
El proyecto se vincula con la afirmación de los valores nacionales que se intentaban consolidar, a finales del XIX, como parte del proceso histórico en el que la sociedad uruguaya reivindicaba la creación de su propia identidad y de una memoria épica unificadora. Su concepción se inicia en 1883 cuando la Asamblea General Parlamentaria decretó su creación y destinó el presupuesto ${ }^{3}$. En 1913 se convocó un concurso internacional ${ }^{4}$ en el que quedaron finalistas la propuesta del escultor uruguayo Juan Manuel Ferrari y la del italiano Ángelo Zanelli. El empate provocó una acalorada discusión social, llegando a la prensa del momento las más variadas opiniones sobre la imagen que debía prevalecer. El proyecto de Ferrari presentaba líneas estilísticas que destacaban rasgos criollos en contraposición a la figura homérica de Zanelli, quien finalmente sería designado ganador del concurso en base a la mencionada estética europeizante ${ }^{5}$.

El vaciado se hizo en la Fondería Chiurazzi de Nápoles. La obra se trasladó por partes a Montevideo para su montaje ${ }^{6}$ y, tras soldarse las piezas, se le aplicó una pátina de sulfuro, a modo de veladura, que permitía disimular las uniones y los detalles del ensamblaje ${ }^{7}$. La obra se inauguró finalmente el 28 de febrero de 1923, es Monumento Histórico Nacional desde 1976, y su actual titular es la Casa Militar.

La intervención se plantea, por tanto, en una obra cargada de simbolismo, que preserva una memoria y una identidad del imaginario uruguayo y que refleja un momento histórico de reafirmación nacional.

\section{Estado de conservación}

El monumento presentaba un delicado estado de conservación relacionado, evidentemente, con el medio urbano en el que se encuentra y que ha sido el origen principal de los procesos de alteración.

La plaza Independencia, en el límite entre la ciudad histórica y la nueva, se caracteriza por tener una gran concentración de tráfico rodado y por estar próxima a industrias químicas, metalúrgicas y al puerto de Montevideo. Esta cercanía a la costa supone, además, una constante exposición a aerosoles marinos y a una humedad relativa muy elevada, con niveles de entre un $80-100 \%$ en muchas épocas del año. El monumento está expuesto también a la radiación solar directa que, además de provocar cambios térmicos y dilataciones diferenciales -la escultura puede pasar, dependiendo del periodo de año, de una temperatura superficial de $0^{\circ} \mathrm{C}$ durante la noche hasta 70$80^{\circ} \mathrm{C}$ durante el día-, favorece reacciones químicas en la superficie del metal. Hay que añadir, además, la acción del viento y la erosión provocada por las partículas que transporta ${ }^{8}$.

Por tanto, su ubicación en una zona altamente urbanizada, caracterizada por bancos de niebla o lluvias más o menos habituales, cercanía al mar, vientos constantes e insolación, evidencia los complejos factores y procesos de alteración que lo han afectado. En mayor o menor medida, todos estos agentes han favorecido la interacción y la reacción con el metal, desarrollando formas características de deterioro.

La deposición de contaminantes y partículas ambientales ha generado, dependiendo de la volumetría y de la orientación del monumento, recubrimientos porosos e higroscópicos que, con mayor o menor grado de adherencia, se manifiestan como costras grises o negras en combinación con compuestos metálicos de corrosión [figura 2]. En el grupo de depósitos hay que incluir también la importante presencia de guano de paloma, principalmente en volúmenes resguardados, en la base de la pieza y en la cabeza del general y del caballo. 
La deposición de sales y partículas higroscópicas ha sido, por tanto, significativa y ha provocado una interacción constante con el metal, incrementando su deterioro. Con frecuencia, debajo de la mayoría de los depósitos y costras se han encontrado áreas de corrosión activa que habían provocado picaduras con pérdida importante de metal.

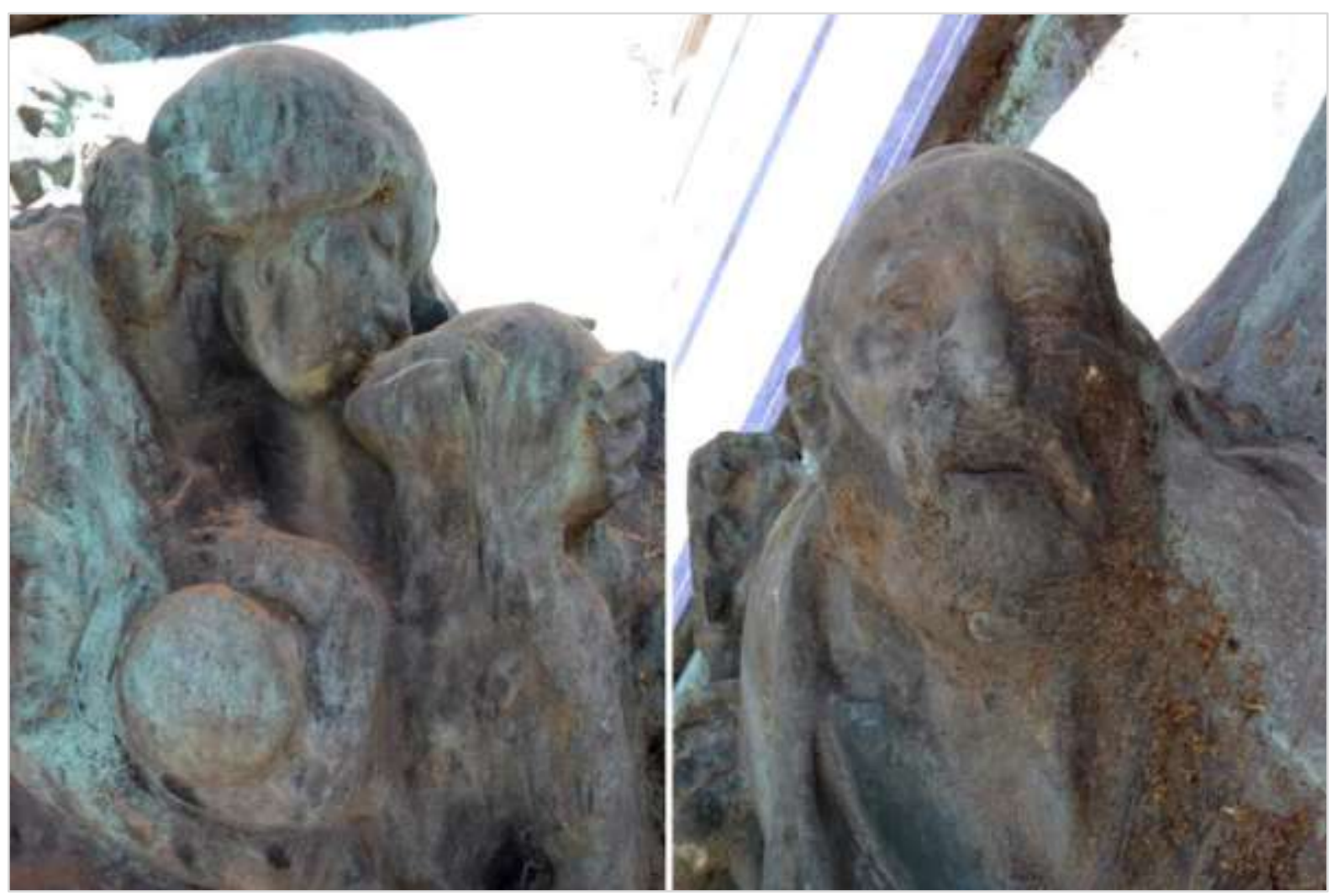

Figura 2. Depósitos superficiales y corrosiones en escenas del relieve perimetral. OJimena Schroeder Claudia Frigerio.

A todo esto hay que añadir el escaso mantenimiento, siempre esporádico, que ha atendido exclusivamente a situaciones de riesgo. Este sería el caso, por ejemplo, de la intervención en la década de 1950 -sustitución de dos patas del caballo y relleno de cavidades debidas a corrosión, con diversas aleaciones metálicas- y de la reparación de otra de las patas en la década de 1970, además de algún lavado superficial en años posteriores. De estas restauraciones no existe documentación y solo aparecen referidas en la prensa escrita, aunque durante la intervención actual se ha podido comprobar el empleo de una gran variedad de materiales y pastas de reintegración en las grietas del relieve y de la escultura, y una diversidad de aleaciones y de pátinas para la reposición e igualación cromática de partes completas 9 .

Tal y como se ha comentado, el pedestal que soporta la escultura y que sirve de marco a los relieves es una estructura de obra revestida con aplacado de granito. Las alteraciones principales se relacionan con la formación de costras carbonatadas y salinas con origen en el lixiviado interno de los morteros, cuyo punto de resurgencia se localiza entre las juntas de las placas. Debido a las condiciones ambientales, la superficie del granito ha perdido su pulido superficial y en algunas de 
las losas se aprecia alteración de los feldespatos y cierta desagregación del material -sin ser una alteración significativa de momento- ${ }^{10}$.

\section{Análisis previos y resultados}

Los análisis previos se vincularon directamente con la intervención, pero también con su mantenimiento posterior. De los resultados se pudieron determinar los elementos mayoritarios de la aleación utilizada, los principales productos de corrosión y el estado de conservación de la estructura interna de apoyo de la escultura, lo que permitió programar un proceso razonado de los trabajos. Pero además, con los datos obtenidos se preveía un estudio posterior sobre las necesidades de mantenimiento -etapa en la que se ha empezado a trabajar- que favoreciesen y facilitasen futuras investigaciones sobre los procesos de deterioro de los bronces expuestos al exterior en un ambiente urbano y salino como el de Montevideo. En esencia se pretendía dotar a los conservadores-restauradores y a las instituciones responsables del patrimonio de herramientas científicas para abordar el plan de conservación ${ }^{11}$.

Antes de proceder al muestreo se realizaron análisis visuales y con lupa 10x para concretar las principales alteraciones, elaborar los primeros mapas de formas de deterioro y seleccionar las áreas de extracción.

Para el estudio de la superficie exterior se tomaron diferentes muestras de la pátina -raspado- y del metal -fragmento- en zonas representativas de las situaciones generales o que presentaban desprendimientos. Estas muestras se inventariaron, se documentaron en la cartografía y se analizaron mediante microscopio electrónico de barrido y espectrometría de energía dispersiva (SEM-EDX) y difracción de rayos X $(\mathrm{XRD})^{12}$. Asimismo, para tener datos precisos sobre el interior de la pieza y de su estructura de apoyo, se realizó una endoscopia.

Los análisis SEM-EDX permitieron determinar semi-cuantitativamente la media general de los elementos mayoritarios ( $\mathrm{Cu}, 64.5 \%$; $\mathrm{Sn}, 22.5 \%$; $\mathrm{Zn}, 9.76 \%$; y $\mathrm{Pb}, 3.14 \%$ ) [figura 3]. El porcentaje de elementos aleantes es muy elevado y se corresponde con aleaciones empleadas normalmente para coladas -el estaño mejora la dureza, y el zinc y el plomo la maleabilidad-. Estas proporciones pueden variar ligeramente según zonas al haberse manufacturado la escultura por partes.

Los análisis SEM-EDX aportaron también información para plantear la XRD y determinar la composición de los productos de alteración. En las muestras analizadas se detectaron principalmente cloruros (elevado porcentaje de paratacamita- $\mathrm{Cu}_{2} \mathrm{Cl}(\mathrm{OH})_{3}$ ) y óxidos de cobre (cuprita- $\mathrm{Cu}_{2} \mathrm{O}$ ), habituales en una escultura expuesta en medio urbano salino.

Por tanto, partiendo de la observación visual y con los resultados de la analítica, se determinó la composición de esta pátina histórica que se manifestaba visualmente con las distintas coloraciones de los compuestos detectados. En algunos casos los cambios de color también se manifestaban como líneas de lavado provocadas por la percolación del agua de lluvia [figura 4]. 


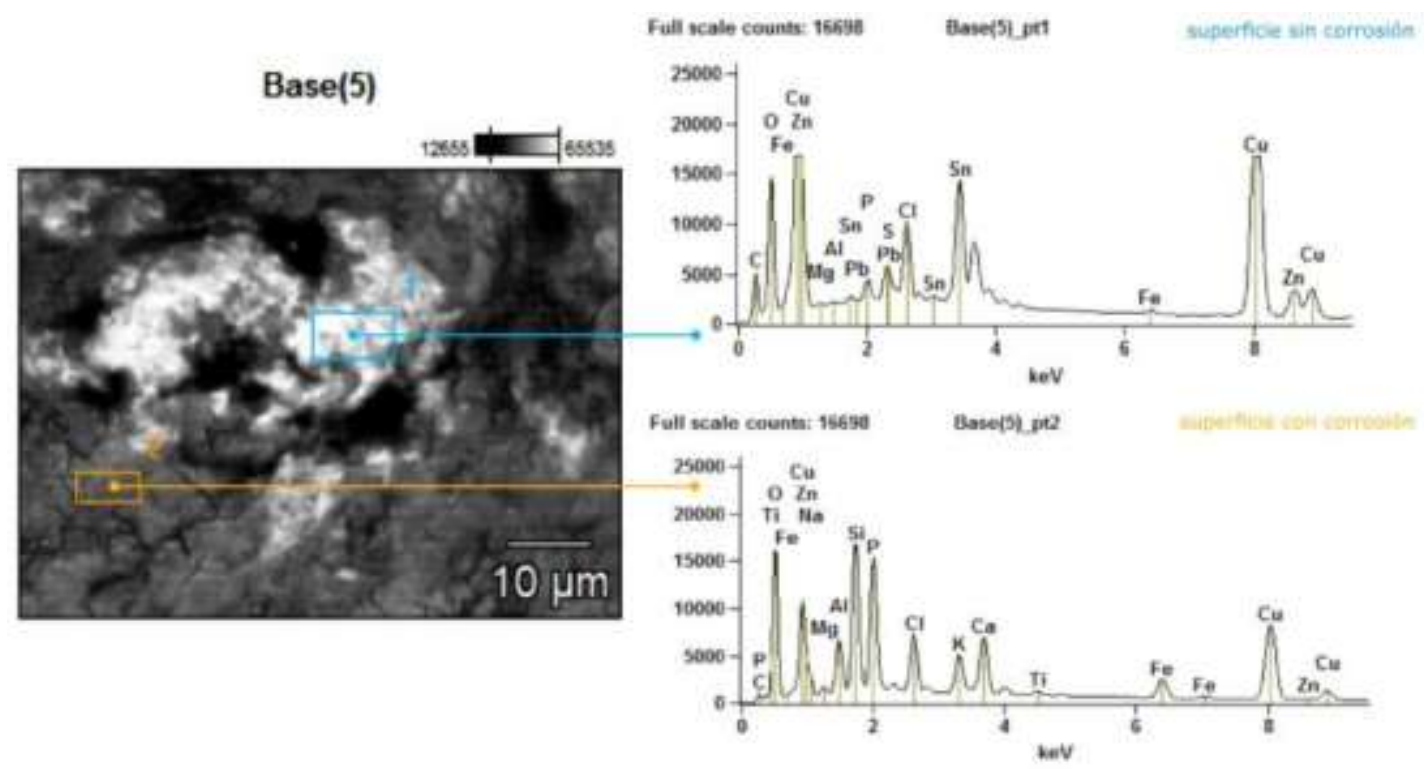

Figura 3. Imagen SEM-BSEl de una de las muestras y espectro de rayos X. (Fotografía: Dr. Alejandro Márquez. Servicio de Microscopía Electrónica de Barrido y Microanálisis. Facultad de Ciencias UDELAR).

Como la cuprita formaba un recubrimiento uniforme, relativamente estable y por lo general bien adherido al sustrato, la paratacamita era, de los existentes, el compuesto que más afectaba y podía seguir afectando a la pieza. Este hidroxicloruro es uno de los que provocan mayor daño en las esculturas de bronce porque el metal que se encuentra atacado por este compuesto actúa como ánodo y favorece el desarrollo de picaduras y pérdidas de material (Díaz y García 2011: 25). Si los cloruros continúan accediendo al metal -en ocasiones los óxidos de cobre actúan como capa protectora y pasivante -el proceso se repite cíclicamente, comprometiendo la conservación de la pieza.

El elevado índice de paratacamita se correspondía visualmente con zonas en las que el proceso se había iniciado con una pérdida parcial de material por cloruros activos -de un $50 \%$ del espesor aproximadamente- $y$ en algunos casos, zonas con pérdida casi total en las que se había perforado el grosor de las paredes, facilitando la penetración de agua en el interior de la escultura. En la pieza, además, cuando se había desencadenado esta reacción, se había formado una capa superficial de productos de corrosión que dificultaba la lectura de los detalles decorativos.

En general, tanto la escultura como el relieve presentaban pérdida de materia puntual pero generalizada. Es difícil establecer el porcentaje, aunque a partir del cálculo de superficie de los mapas de alteración, se podría establecer en torno al 3\%.

Junto a estos procesos de corrosión también se han detectado fisuras y grietas. En el relieve aparecían normalmente en las soldaduras de las diferentes partes; y en la escultura, se localizaban en la parte baja de las patas traseras, favorecidas probablemente en este caso, a una acción combinada del esfuerzo de tracción en un ambiente corrosivo. 
En el monumento, resumiendo lo expuesto, se han documentado diferentes tipos de corrosión. Además de la corrosión en la zonas que trabajan bajo tensión, se ha observado corrosión electroquímica con formación de picaduras por acción de los cloruros y, en algunos casos, una posible corrosión diferencial producto del contacto de aleaciones de bronce de diferente composición (ya que se localiza entre original y reposición en la pata delantera derecha y sobre las ancas del caballo). También se han detectado corrosiones localizadas entre algunos de los injertos realizados para solventar problemas de ensamblaje durante el montaje original, debidos probablemente al empleo de una aleación diferente a la de la colada para adaptarla a las necesidades de manipulación (Askeland 2001: 713-723).
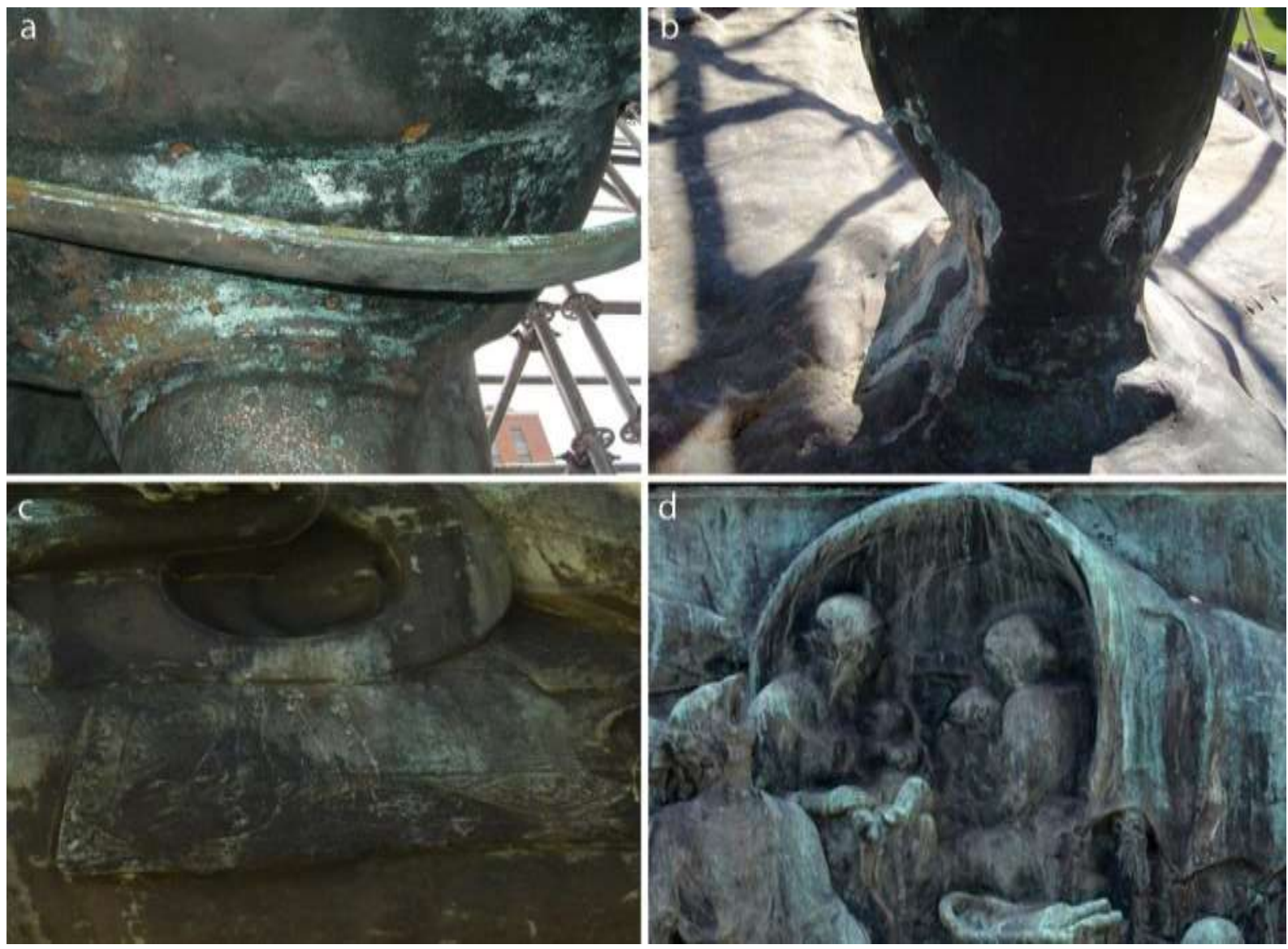

Figura 4. Diferentes corrosiones en el monumento: (a) cloruros activos tras varios días de niebla continuada, (b) corrosión en zonas que trabajan bajo tensión -grieta en la pata del caballo-, (c y d) corrosiones y líneas de lavado. OJimena Schroeder - Claudia Frigerio.

Con la colaboración del Equipo Técnico del Departamento de Ingeniería Aeronáutica de la Fuerza Aérea Uruguaya, también se realizó el estudio endoscópico del interior de la escultura. Su finalidad era obtener una información y un registro fotográfico que documentase el estado de la estructura interna de anclaje, a la vez que se analizaban de forma no invasiva las paredes interiores de la pieza. 
Para la endoscopia se utilizaron los orificios de respiración de la escultura; solo en la pata izquierda trasera se hizo una perforación a la altura de la viga de apoyo porque la abertura original se encontraba sellada con un relleno de estaño-plomo.

La exploración no mostró daños relevantes en el interior de la pieza ni en la estructura de hierro que le sirve de apoyo. En la estructura la corrosión era muy superficial y la integridad del pilar no se veía comprometida. Solo puntualmente se observó abundante corrosión recubriendo la estructura, aunque al descubrir parte de la superficie del metal se comprobó escasa penetración [figura 5].

La endoscopia permitió también documentar la existencia de áridos en el vientre del caballo, posiblemente restos de arena del vaciado que se habrían desprendido con el tiempo, y una capa de resina con fibra de vidrio en el cuarto delantero, probablemente de la intervención de la década de 1970.
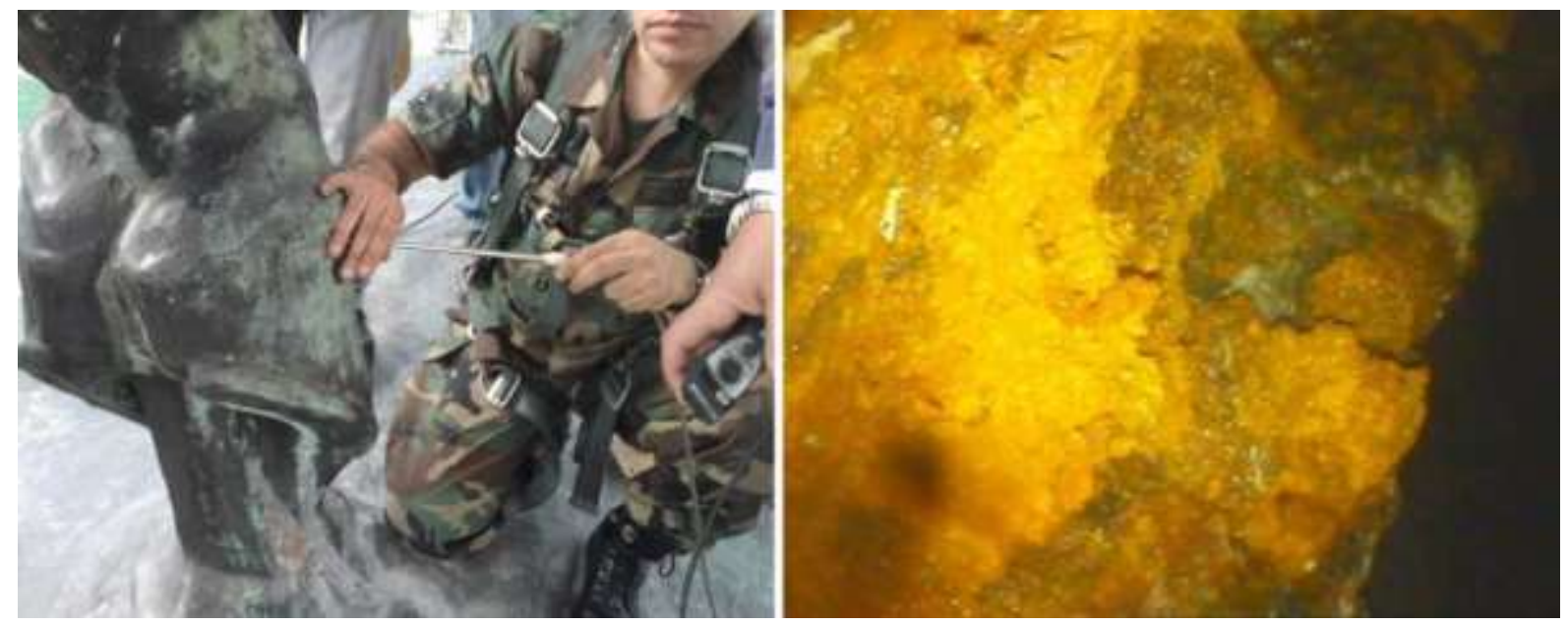

Figura 5. Proceso de realización de la endoscopia (izquierda) e imagen endoscópica de mineralizaciones en la estructura interna de la escultura (derecha). (Fotografías: Equipo Técnico de la Fuerza Aérea Uruguaya. Departamento de Ingeniería Aeronáutica).

\section{Intervención}

Tras un proceso exhaustivo de investigación histórica, técnica y material del monumento, los datos se registraron en cartografías y fichas que permitieron visualizar la localización de las lesiones y planificar tratamientos generales y específicos según las superficies [figura 6]. La intervención, realizada entre los meses de marzo y septiembre de 2012, debía incidir en las zonas con procesos de corrosión degenerativos, eliminando y estabilizando los elementos nocivos que afectasen activamente a la obra e impidiesen su correcta lectura, y buscando unas condiciones adecuadas de conservación ${ }^{13}$.

Para la eliminación de los depósitos superficiales, y debido al gran tamaño de la pieza, la limpieza general se realizó mediante proyección de abrasivos. Primero se hicieron catas con abrasivos minerales sintéticos -óxido de aluminio blanco de $63 \mu \mathrm{m}$ y microesferas de vidrio 53-106 $\mu$-con presiones mínimas en manómetro de 1 bar, distancia entre $10-15 \mathrm{~cm}$ y ángulo de $70^{\circ}$, que dejaron a la vista el metal. A pesar de la baja presión, la dureza y la forma de estos abrasivos -9 y 7 Mohs; y 
angular y esférica respectivamente-, parecían ejercer mecanismos de fricción e impacto que traspasaban todos los recubrimientos de la superficie.

Se optó por probar con abrasivos orgánicos naturales, en este caso triturados de cáscara de almendra. El empleo de triturados vegetales está documentado en diferentes intervenciones y estudios, y entre los disponibles, podría considerarse uno de los más conservativos para las pátinas estables del metal por su baja dureza -3 Mohs- (Iglesias y Arbués 2009; Morigi 2004; Veloz 1993). A pesar de su forma angular presenta, por sus características, un cierto comportamiento elástico que parece reducir los daños observados con algunos de los productos más habituales de comportamiento plástico. Se ensayó con presiones que oscilaron entre 1 y 6 bar, modificando distancias y ángulos, y se comprobó que incluso con presiones elevadas no se provocaba modificación superficial.

Se usó en concreto granulometría cercana a $300 \mu \mathrm{m}$ y se proyectó con un equipo de presión directa y boquilla recta de $3 \mathrm{~mm}$ de diámetro, lo que permitió una aplicación puntual y localizada según las variaciones de distancia -entre 5 y $15 \mathrm{~cm}$ dependiendo de la volumetría de la zona y de la dureza del depósito-, presión en manómetro de 5 bar y ángulo de $70^{\circ}$-parámetros determinados a partir de las pruebas iniciales-. Con esta limpieza mecánica se evitaban, además, los riesgos de tratamientos químicos generalizados [figura 7].

Antes de proyectar y debido a la composición orgánica de estos triturados, las fisuras, grietas y orificios se limpiaron y sellaron para impedir que pudieran penetrar y quedar residuos del producto en el interior. En las microfisuras se inyectó Paraloid ${ }^{\oplus}$ B-72 al $40 \%$ en acetona; las pequeñas fisuras se rellenaron con resina epoxi UHU ${ }^{\circledR}$; y en separaciones $u$ orificios de mayor tamaño, resina epoxi cargada con bronce micronizado Devcon Bronze Putty ${ }^{\circledast}$. Antes de optar por el sellado con resina se realizó una prueba con soldadura en una de las grietas de la base de la escultura, pero al comprobar la elevada temperatura que finalmente alcanzaba el metal, se desestimó.

Asimismo, como cualquier granalla vegetal tiene en composición un pequeño porcentaje de grasas -en torno a un $2.7 \%$-, tras finalizar la limpieza se paso alcohol etílico embebido en paños de algodón por toda la superficie ${ }^{14}$.

Esta técnica sirvió para eliminar la mayoría de depósitos superficiales, aunque en zonas aisladas que presentaban mayor grosor, dureza y compacidad, y que impedían además la correcta lectura de la obra, se realizó una limpieza mecánica con microtorno y bisturi ${ }^{15}$.

Para los cloruros, de entre los posibles tratamientos químicos que resultasen relativamente fáciles de aplicar en exterior y en grandes superficies, se seleccionó una variante del método Rosenberg (Mourey 1987: 99) ${ }^{16}$, ya que el tratamiento con óxido de plata resulta más caro y más lento al tener que sellar individualmente cada foco de cloruro, y tampoco se consiguió comercialmente en el país. Tras sanear mecánicamente con bisturí o microtorno la superficie afectada se tuvieron que realizar sucesivas aplicaciones por el importante ataque de cloruros. El tratamiento finalmente se evaluó como efectivo al comprobar que, tras mantener la zona tratada a un $100 \%$ de humedad relativa durante periodos de 24 horas, no aparecían nuevos focos activos [figura 8].

Las áreas más resistentes al tratamiento, que presentaban un ataque masivo entremezclado con la capa de óxido de cobre, se localizaron en el interior de la boca, en la parte baja de la cola y en los genitales del caballo. En estos casos se necesitó llegar al metal para proceder de manera efectiva. 
Una vez finalizados los tratamientos se recuperó la legibilidad de muchas zonas de la obra y en especial de los documentos que el General lleva en la mano, pudiéndose leer fácilmente el final del artículo 20 de las Instrucciones del año XIII.

Las áreas de injertos anteriores -normalmente aleaciones rígidas de cobre, plomo y estaño que se decidieron mantener porque su retirada suponía mayor daño a la pieza- y las realizadas con resinas en esta intervención, se reintegraron cromáticamente mediante tintas planas en un tono más bajo que el original con Paraloid ${ }^{\boxplus}$ B-72 al $4 \%$ en acetona y pigmentos minerales Kremer.

La protección final de la escultura y del relieve se realizó con Incralac ${ }^{\circledR}$-Paraloid ${ }^{\circledR}$ B-44 y benzotriazol- producto que reduce los problemas de amarilleamiento de las películas protectoras expuestas a radiación UV, tiene resistencia al impacto térmico, y es estable y reversible [figura 9]. Se pensó en adicionar al Incralac un agente matizador para reducir el brillo que deja, pero al tratarse de un efecto estético que con el tiempo desaparece de manera natural por la acumulación de polvo ambiental y por la interacción con el medio ambiente, se desestimó finalmente para evitar posibles efectos secundarios no controlados.
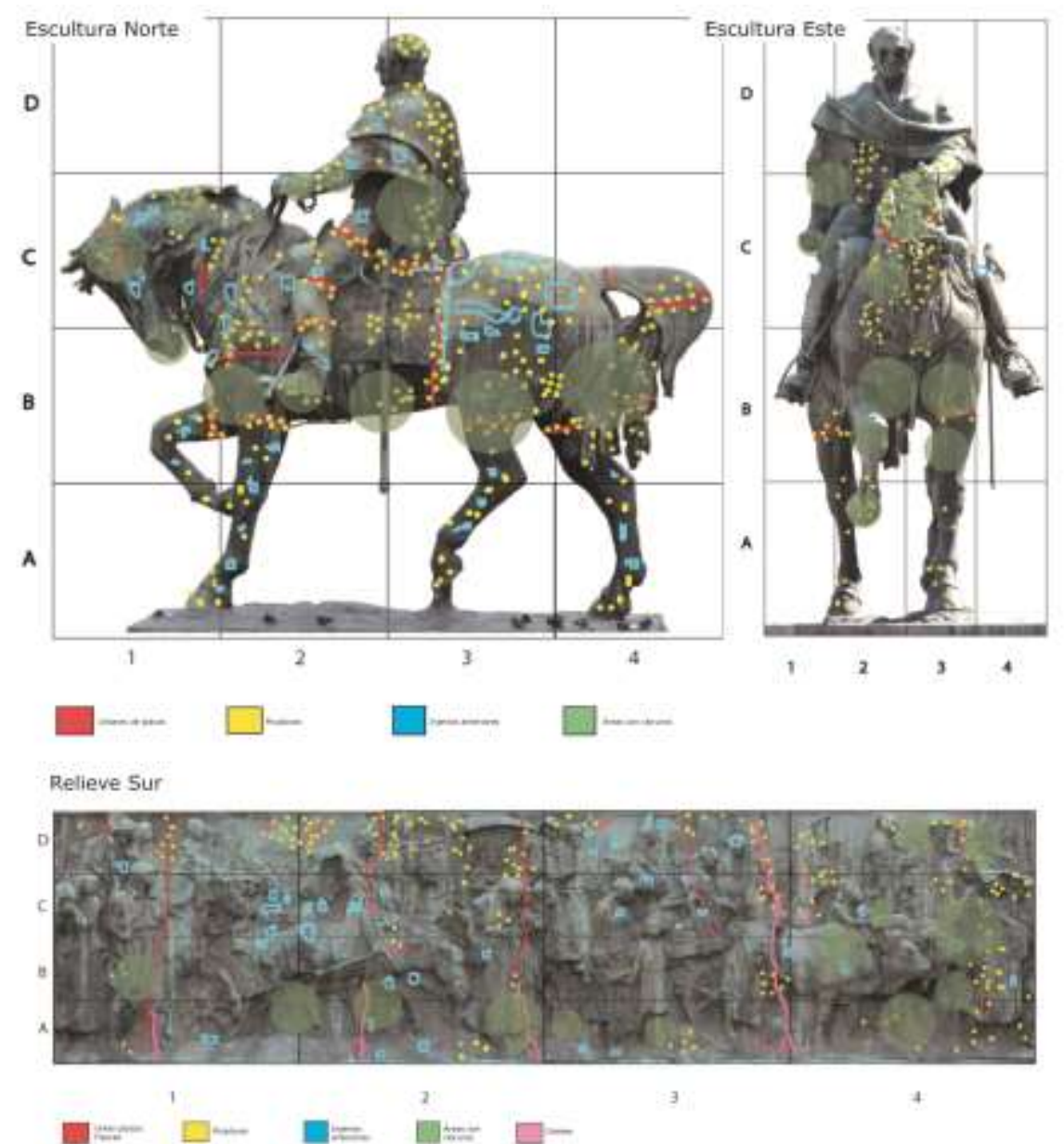

Figura 6. Mapas de alteración de la escultura (superior) y del relieve perimetral (inferior). El tamaño de la lesión es indicativo de la ubicación y no se corresponde proporcionalmente con la escala real. (Mapas y fotografías: Claudia Frigerio - Jimena Schroeder). 
El monumento al General José Gervasio Artigas: la conservación-restauración de escultura

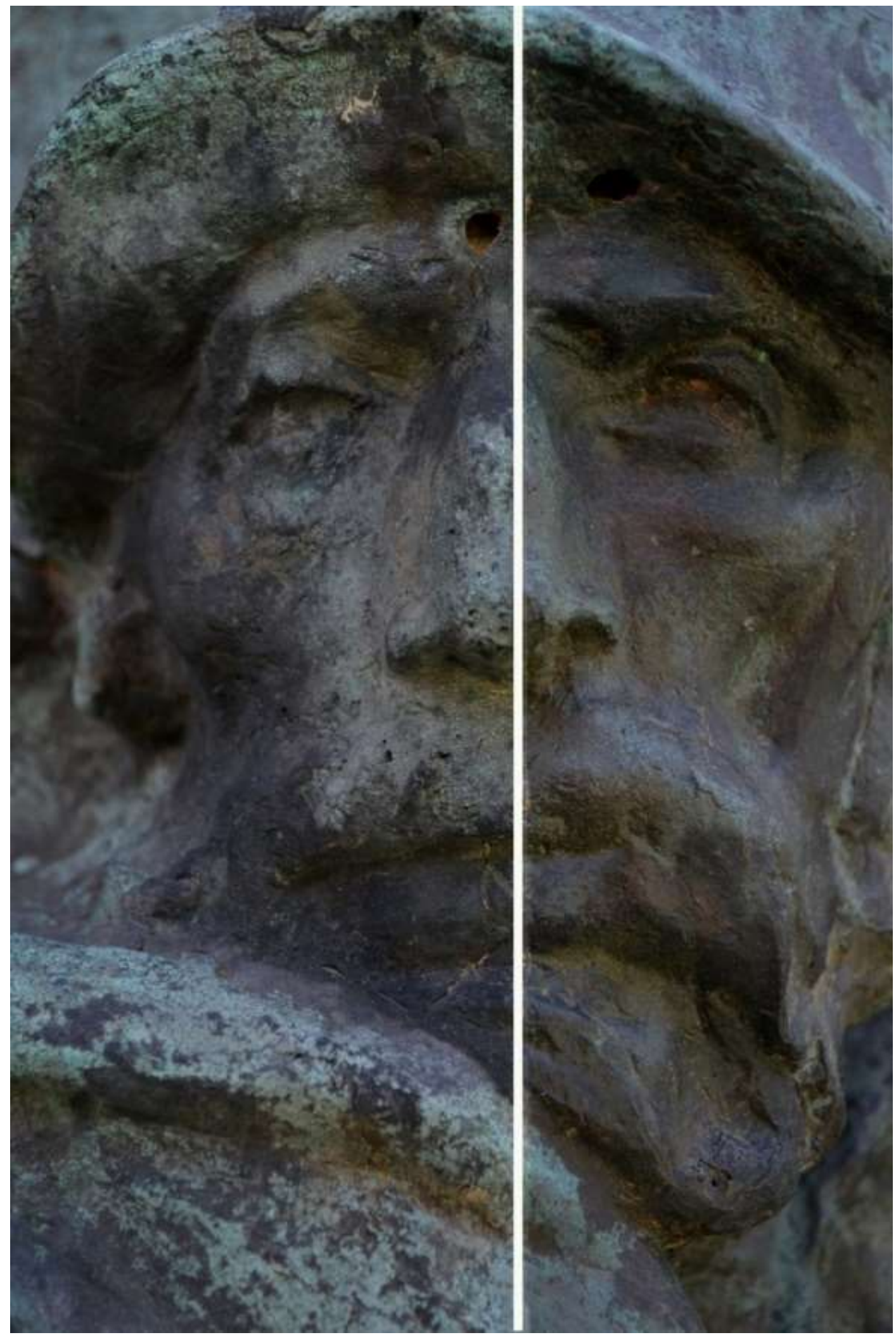

Figura 7. Detalle de limpieza con proyección de granalla vegetal en un busto del relieve perimetral. @Jimena Schroeder-Claudia Frigerio. 

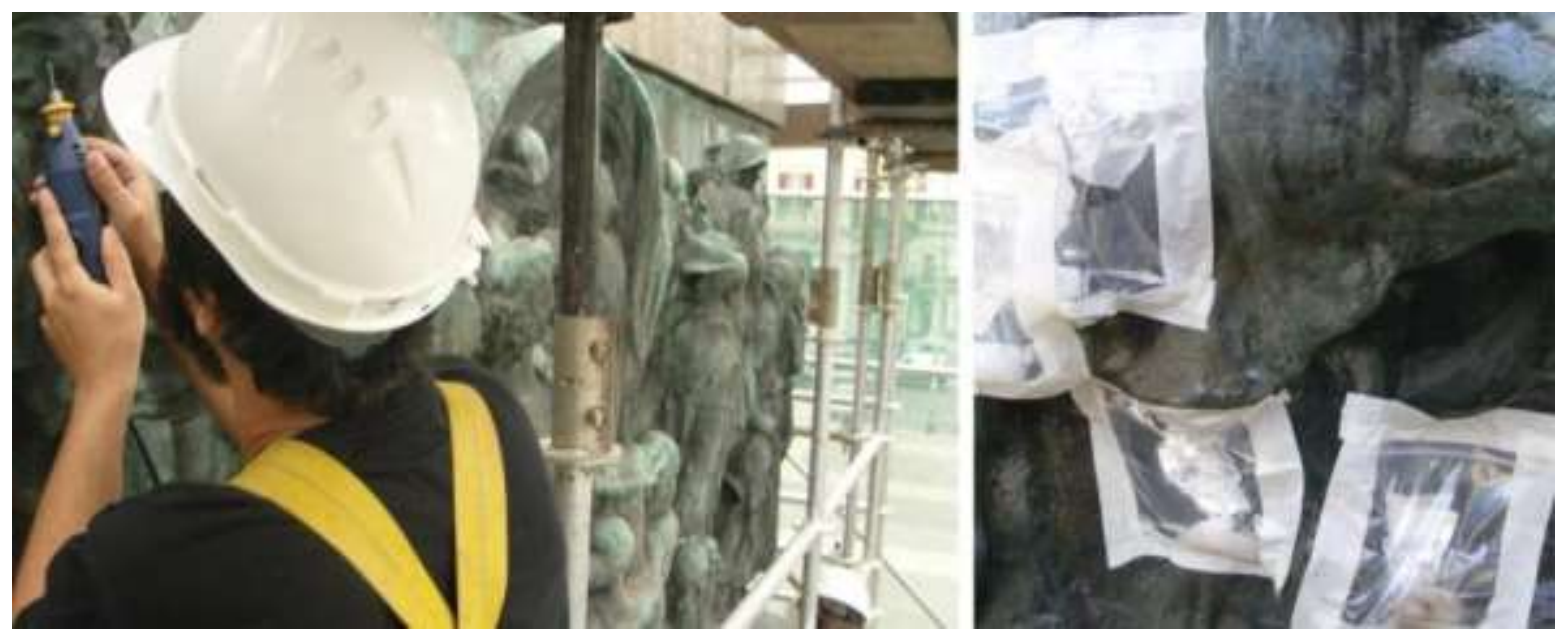

Figura 8. Diferentes tratamientos de las corrosiones: microtorno (izquierda) y método Rosenberg (derecha). OJimena Schroeder-Claudia Frigerio.

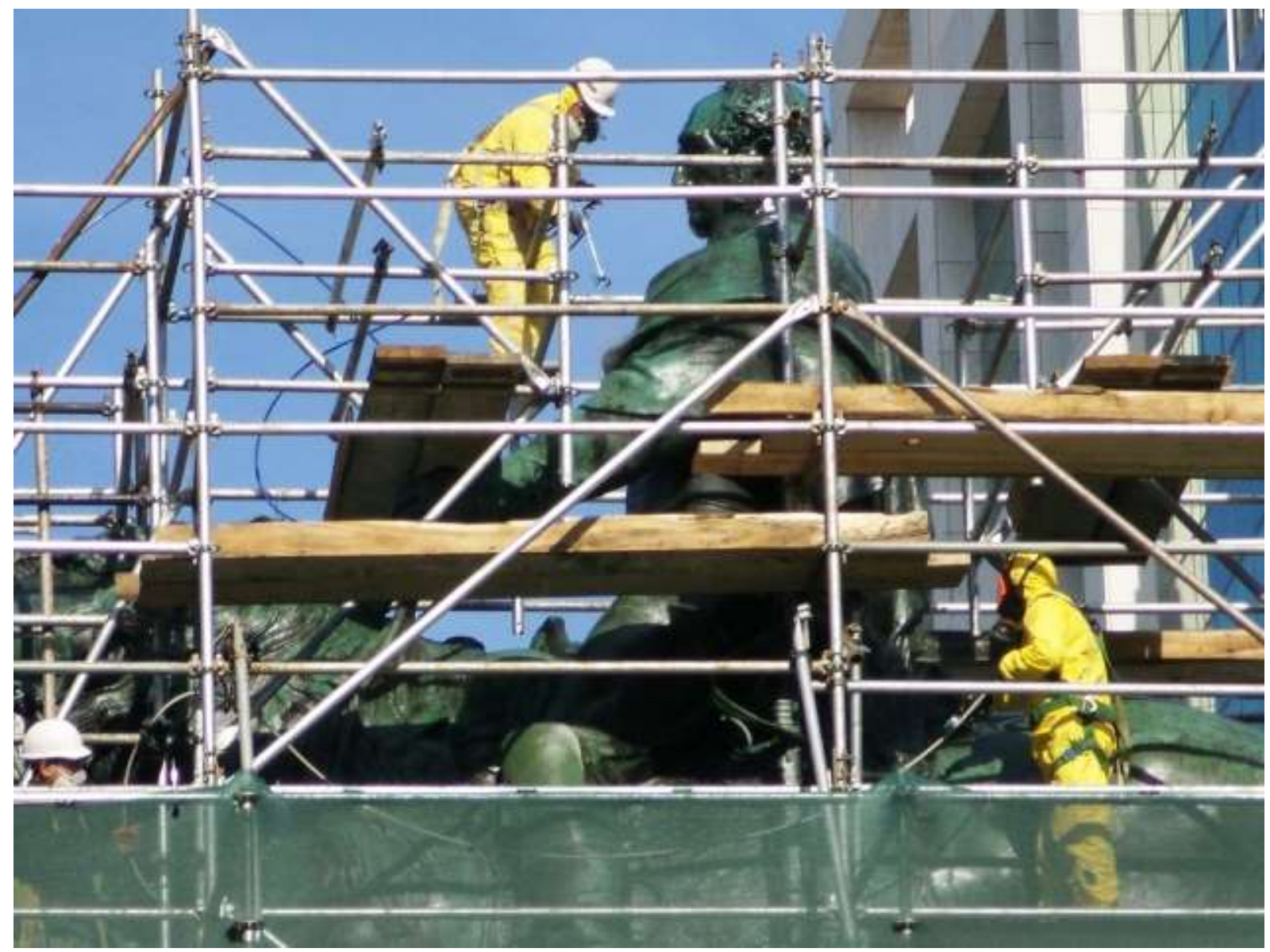

Figura 9. Aplicación del tratamiento protector. @Jimena Schroeder - Claudia Frigerio. 


\section{Conclusiones}

La comunicación entre el equipo de investigadores y restauradores durante el estudio previo y a lo largo de la intervención, permitió programar y realizar de una manera razonada los diferentes tratamientos necesarios para su conservación.

Estos tratamientos, seleccionados a partir de los resultados y testados y estudiados previamente in situ, se adaptaron a las necesidades presupuestarias y temporales de una intervención sobre un monumento de gran tamaño. Al poder utilizar la técnica mecánica de proyección de abrasivos vegetales para la limpieza general se redujeron en gran medida los tratamientos químicos, que solo se emplearon de manera puntual y localizada. También se tuvo una especial atención en el sellado de fisuras y grietas y en la aplicación de la capa protectora ya que estos tratamientos son los que evitarán o reducirán los efectos de los agentes de alteración en la superficie y en el interior de la pieza.

Se pudo comprobar y documentar la composición general de la aleación empleada y los productos de corrosión que más afectaban al monumento, así como una primera aproximación al estado de conservación del interior de la escultura.

Los procedimientos se valoraron como adecuados para la situación y con toda la información se ha planteado una propuesta de seguimiento y manteamiento para estudiar su evolución [figura 10].
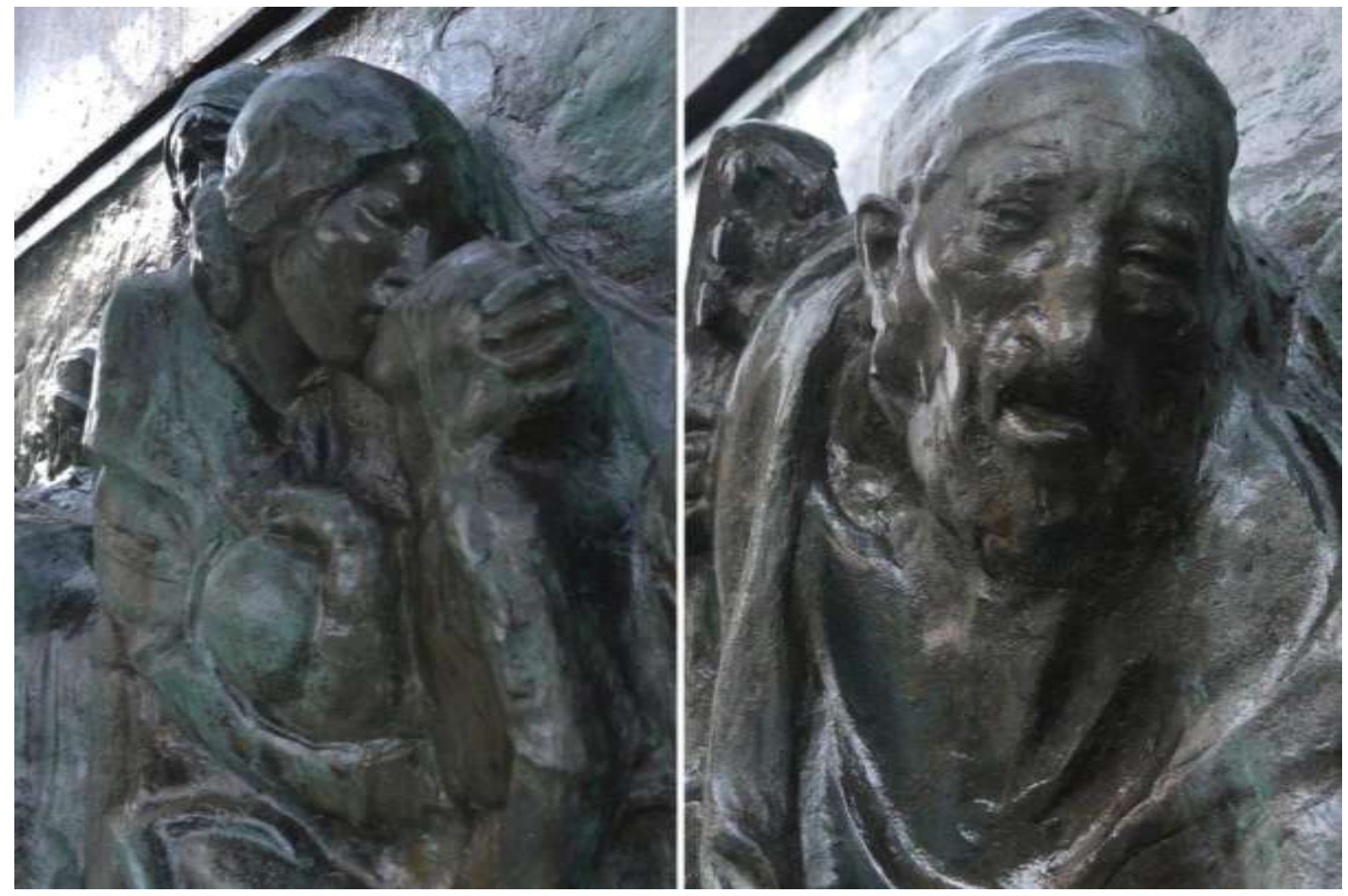

Figura 10. Detalle del acabado final en dos escenas del relieve perimetral. (C)imena Schroeder - Claudia Frigerio. 


\section{Seguimiento y mantenimiento}

Tras finalizar los trabajos, las autoridades responsables del monumento disponen de una documentación fotográfica y de un informe detallado del estado actual que sirve de base para revisar y periodizar el mantenimiento.

El importante valor simbólico e histórico de la obra ha permitido concienciar sobre la necesidad de un mantenimiento programado que permita conservarlo en las mejores condiciones posibles y de establecer un plan de conservación para el resto de los monumentos públicos.

Por el momento, y desde la finalización de la intervención, la Intendencia Municipal de Montevideo lleva a cabo el control de aves en la zona mediante una empresa privada, y la Dirección Nacional de Arquitectura, junto con el titular del bien, están profundizando en el estudio de algunas de las muestras catalogadas para entender y prever la evolución que la obra puede tener al resultar imposible modificar las condiciones ambientales del espacio para el que fue pensada.

Se ha propuesto como parte del mantenimiento, una limpieza anual con agua nebulizada para evitar dañar la capa de protección y eliminar los depósitos superficiales que se puedan formar. Estos trabajos, que se podrían realizar con sistema elevador y durar un par de días, servirían también para detectar posibles alteraciones en la protección y controlar la evolución del tratamiento realizado.

El control sobre la capa de protección se considera esencial ya que es la que reduce la interacción de los agentes de alteración con el metal. Sería recomendable que al menos cada cinco años se retirase y se sustituyese por una nueva porque, aunque la efectividad del producto está documentada para periodos mayores, las condiciones ambientales de la obra podrían reducir su durabilidad y reversibilidad.

Se ha insistido también en que la planificación del mantenimiento deberá realizarse con suficiente antelación para gestionar los trámites para la importación de los productos que no se encuentran en el país y prever su ejecución en los meses menos lluviosos y húmedos (marzo-junio).

Además de los trabajos de mantenimiento en la superficie de la escultura, los especialistas están programando controles periódicos de la estructura interna de anclaje y fijación. Al efectuar un mantenimiento del exterior, que reducirá y minimizará la acción de los agentes ambientales, las revisiones internas podrán ser más espaciadas en el tiempo.

Sobre el aplacado de granito también se ha recomendado una limpieza superficial para evitar que las sales del lixiviado de la estructura interior se insolubilicen y encostren. En este sentido, la arquitecta Magela Terzano, de la Comisión Nacional del Patrimonio Cultural, ha presentado posibles soluciones actualmente en fase de estudio por la coordinadora de los trabajos.

\section{Notas}

[1] Con estas Instrucciones se proclamó por primera vez la independencia de los territorios del Río de la Plata, se planteó un régimen republicano de gobierno y la confederación de las Provincias.

[2] La emigración colectiva de habitantes de la Banda Oriental, territorio ubicado al este del río Uruguay y al norte del Río de la Plata, que siguió a José Gervasio Artigas hasta el Salto Chico -actual ciudad argentina de Concordia- después del armisticio de octubre de 1811 se considera uno de los hechos centrales en la formación del sentimiento de identidad uruguayo.

[3] En el decreto se especifica que será "para una estatua ecuestre en bronce a la memoria del general Artigas [...], con un pedestal de granito de Las Piedras en el que se grabará la inscripción «Artigas» [...], y que se erigirá en el centro de la plaza de la Independencia de la Capital de la República" (Rela 2000: 33). 
[4] “[...] al que podrán concurrir los escultores uruguayos y extranjeros que lo deseen, instituyéndose dos premios en dinero", y, "con el propósito de asegurar la concurrencia de escultores de fama mundial se pedirán bocetos a cinco grandes artistas" (Rela 2000: 38).

[5] Angelo Zanelli (1879-1942) fue un escultor italiano que trabajó principalmente en arte público conmemorativo. Entre las obras más conocidas está el Monumento a Vittorio Emanuele Il, en la plaza Venecia de Roma.

[6] Parece ser habitual que Zanelli supervisase la colocación de sus piezas. Existe documentación, por ejemplo, de un viaje suyo a La Habana (Cuba) en 1929 para controlar la colocación de su escultura "La República" en el pedestal del Capitolio.

[7] Las pátinas de sulfuro fueron muy utilizadas por los artistas del siglo XIX que asimilaban este color a la imagen de belleza clásica. Su origen se relaciona con los descubrimientos de bronces arqueológicos que aparecían con una pátina negra producto de las condiciones ambientales en las que habían permanecido enterradas durante siglos (Díaz y García 2011: 35).

[8] Un estudio reciente sin publicar, realizado por Técnicos de Facultad de Ingeniería, indica que la zona de emplazamiento de la escultura es una de las más afectadas por los vientos en la ciudad de Montevideo.

[9] La pata trasera izquierda fue claramente intervenida y presenta una pátina muy débil, casi nula. El Sr. Laborde, hijo del escultor que realizó la intervención, constató que su padre la había cambiado en la década de 1970. Se sabe también que dos patas más se cambiaron en la década de 1950 pero no se ha podido establecer con claridad cuáles son; las variaciones de color son muy ligeras y tampoco se aprecian uniones muy diferentes a las generales de la pieza. En esta misma intervención, aprovechando los andamios colocados, José Belloni realizó una réplica de la cabeza de la escultura que actualmente se exhibe en el Museo Histórico Nacional. Se desconoce si en ambas intervenciones se hicieron tratamientos conservativos en el metal. Durante los trabajos se tomaron diferentes muestras que se catalogaron y almacenaron en la Comisión del Patrimonio Cultural de la Nación con el objetivo de estudiarlas en el momento en que fuera posible y suplir esta falta de información.

[10] A pesar de formar parte del diseño del monumento, como el artículo se centra en la conservación de esculturas en bronce, las observaciones al estado de conservación de los materiales pétreos se exponen solo como simple referencia.

[11] Es necesario remarcar la importancia de acceder a un monumento que se va a intervenir para recoger el máximo de información, independientemente de si el presupuesto permitirá realizar todos los análisis necesarios. Las muestras, referenciadas y almacenadas como si de una pieza de museo se tratara, son una fuente de información fácilmente accesible en el momento en que se disponga de dinero para profundizar en la investigación.

[12] Se utilizó un microscopio electrónico de barrido SEM Jeol JSM-5900LV a 20kV con sonda de EDS Thermo Ultra Dry y software Seven System. Para la XRD se utilizó el Compact X-Ray Diffraction Analyser System PW1840 Philips. Los difractogramas fueron adquiridos con la radiación Ka del Cu $(\lambda$ $=1.5406 \AA$ ), con filtro de $\mathrm{Ni}$ en el haz primario y sin monocromador secundario. En todas se cubrió el intervalo angular $(2 \theta)$ entre $5^{\circ}$ y $105^{\circ}$, con un paso de $0.04^{\circ}$ y un tiempo de integración de 4 s por paso.

[13] Se considera necesario indicar que muchos de los productos empleados han sido importados ya que no se comercializan en Uruguay.

[14] Existen granallas plásticas, con dureza similar a las vegetales, que se utilizan en determinadas aplicaciones industriales porque no modifican la superficie del metal. Con ellas se podrían haber reducido los residuos de tratamiento comentados, pero el elevado coste de los plásticos triturados dificulta su uso en la mayoría de intervenciones donde es imposible recuperar, limpiar y reutilizar el producto. Dentro de la técnica de proyección sobre grandes superficies de metal se está en fase de experimentación con la limpieza criogénica (Van der Molen, Joosten, Beentjes y Megens 2011) 
aunque su coste sigue siendo más elevado y plantea cierta dificultad en la aplicación y mantenimiento del producto.

[15] La proyección con triturados vegetales no resultaba efectiva en estos casos por su baja dureza y el empleo de abrasivos minerales sintéticos más duros -microesfera de vidrio u óxido de aluminio-, como se ha comentado, eliminaba totalmente la pátina.

[16] El método consiste en esencia en aplicar en los puntos de cloruros agar-agar y glicerina, recubriéndolos con papel de aluminio. Por exposición a una humedad relativa del $100 \%$, se obtienen cloruros de aluminio que se solubilizan a continuación en agua.

\section{Bibliografía}

ASKELAN, D. R. (2001). Ciencia e Ingeniería de los materiales. Madrid: Thomson Editores Spain Paraninfo S.A.

DÍAZ, S., GARCÍA, E. (2011). Técnicas metodológicas aplicadas a la conservación-restauración del patrimonio metálico. Madrid: Ministerio de Cultura. http://www.calameo.com/read/000075335c184bd7c7b68 [consulta: 12/02/2012].

IGLESIAS, M. A., ARBUES, M.J. (2009). "Empleo de abrasivos vegetales por proyección a baja presión en la limpieza de metales arqueológicos". En MetalEspaña'08. Madrid: Gráficas 82, S.L, 213-218.

MORIGI, G. (2004). "La pulitura a micropeening con granulati vegetali". En Monumenti in bronzo all'aperto: esperienze di conservacione a confronto. Firenze: Nardini Editore, 95-97.

MOUREY, W. (1987). La conservation des antiquités métalliques: de la fouille au musée. Draguignan: LCRRA.

RELA, W. (2000). Uruguay. Cronología histórica documentada II. Montevideo: Biblioteca Virtual Histórica del Uruguay.

VELOZ, N.F. (1993). "Practical aspects of using walnut shells for cleaning outdoor sculpture". APT Bulletin, vol. 25, no 3-4: 70-76.

VAN DER MOLEN, R.; JOOSTEN, I.; BEENTJES T.C.P., et al. (2011). "Dry-ice blasting for the conservation cleaning of metals". En Metal 2010. Charleston: ICOM, 135-143. http://www.lulu.com/shop/clemson-university/metal2010-proceedings-of-the-interim-meeting-of-the-icom-cc-metal-working-group-charleston-south-carolinausa11-15-october-2010-digital-version/ebook/product-1 8691539.html [consulta: 01/09/2012].

\section{Agradecimientos}

A los operarios y conservadores que han trabajado en la intervención y a los técnicos e instituciones que contribuyeron a la materialización de este proyecto.

Al Museo Histórico Nacional Casa Giro, al Centro Municipal de Fotografía y a la Comisión del Patrimonio Cultural de la Nación por su contribución en la documentación del registro histórico.

A la Presidencia de la República, a la Casa Militar y al Ministerio de Transporte y Obras Públicas, por su colaboración, interés y disposición.

\section{Equipo de trabajo}

Investigación, proyecto y coordinación en conservación-restauración: Claudia Frigerio Vidal. Investigación en conservación-restauración: Manuel Angel Iglesias Campos.

Asesoría en Historia: Beatriz Vidal Castiglioni. 
Fotografía: Jimena Schroeder y Claudia Frigerio Vidal.

Análisis de Laboratorio: Dr. Alejandro Márquez del Servicio de Microscopía Electrónica de Barrido y Microanálisis de la Facultad de Ciencias UDELAR. M.Sc. Ricardo Faccio del Centro de Análisis por Difracción de Rayos X de la Facultad de Química UDELAR. Dr. Daniel Ariosa y Dr. Enrique Dalchiel de la Unidad de Difracción de Rayos-X. Laboratorio de Física del Estado sólido, Instituto de Física de la Facultad de Ingeniería UDELAR.

Endoscopia: Tte. $1^{\circ}$ Ing. Miguel Etchevarren Aguerre. Hon. Jefe de Ensayos No Destructivos. Equipo Técnico de la Fuerza Aérea Uruguaya. Departamento de Ingeniería Aeronáutica.

Empresa contratista: Hidro-Tec Recuperación Edilicia.

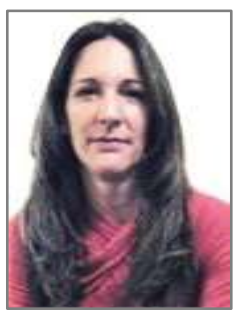

\section{Claudia Frigerio Vidal}

frigeriocl@gmail.com

Restauradora de Escultura. Ha realizado diferentes estancias de especialización, avalada por la Facultad de Humanidades y Ciencias de la Educación, integradas en el plan de Profesionalización de Restauradores Latinoamericanos del Instituto Nacional de Antropología e Historia INAH. Actualmente es Asesora del Área de Conservación de la Dirección Nacional de Arquitectura del Ministerio de Transporte y Obras Públicas de la República Oriental del Uruguay.

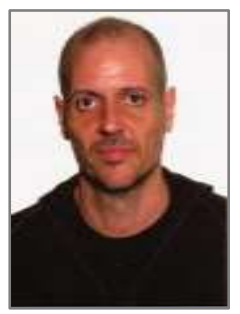

Manuel Angel Iglesias Campos

manuel.iglesias@ub.edu

Doctor en Conservación-Restauración por la Universidad de Barcelona. Miembro de los grupos de investigación CETEC-patrimoni (UAB-IQS) y Conservació-Restauració del Patrimoni (UB). Actualmente es profesor de la Secció de Conservació-Restauració de la Facultat de Belles Arts (Universitat de Barcelona). Su línea de investigación se centra en el tratamiento de materiales del Patrimonio Arquitectónico y Monumental.

Artículo recibido el 02/01/2013

Artículo aceptado el 17/04/2013 


\title{
As reservas visíveis do Schaulager, em Basileia
}

\author{
Maria Fernando Gomes, Eduarda Vieira
}

\begin{abstract}
Resumo: No âmbito da investigação científica sobre condições de reserva de instituições museológicas, pretende-se realizar uma abordagem sobre reservas visíveis e ou visitáveis, incluindo a apresentação de boas práticas. O actual artigo resulta da visita realizada a um caso de estudo: o Schaulager, em Basileia na Suíça. É um exemplo de referência no panorama europeu, no domínio da concepção de reservas e na gestão da articulação entre a conservação, o estudo, a contemplação e a difusão das colecções de arte contemporânea.
\end{abstract}

Palavras-chave: Reservas visíveis, reservas visitáveis, Schaulager, conservação preventiva, arte contemporânea.

\section{Los almacenes visibles del Schaulager, en Basilea}

Resumen: En el campo de la investigación científica sobre las condiciones de almacenes de las instituciones museísticas, pretendemos centrarnos en los almacenes visitables, incluyendo la presentación de buenas prácticas. El presente artículo es el resultado de la visita a un caso de estudio: el Schaulager en Basilea, Suiza. Es un ejemplo de referencia en la escena europea en el ámbito de la concepción de las reservas y su gestión así como de la relación entre la conservación, el estudio, la contemplación y la difusión de las colecciones de arte contemporáneo.

Palabras clave: Almacenes visibles, almacenes visitables, Schaulager, conservación preventiva, arte contemporáneo.

\section{The visible storage of Schaulager, in Basel}

Abstract: Within the scope of scientific research about museum storage conditions, it is presented an approach to visible or open storage spaces, including a frame for best practices. This paper results of a visit carried on to a case-study storage: Schaulager in Basel, Switzerland. It is a model reference in the European context for the storage conception and for the management between conservation, study, contemplation and dissemination of contemporary art collections.

Keywords: Visible storage, open storage, Schaulager, preventive conservation, contemporary art

\section{Introdução}

Hoje, e de modo crescente, assistimos a uma nova prática cultural ao nível da relação que se estabelece entre o discurso expositivo e a conservação das colecções. O primado da comunicação nos museus (Hooper-Greenhill 2000) desempenha um papel decisivo neste domínio. Os museus dispõem de uma diversidade de métodos de comunicação, ajustando-se às presentes necessidades dos visitantes (Hooper-Greenhill 1999: 29). A actual tendência passa por dar maior visibilidade a locais dentro do edifício do museu, concebidos para funcionarem como espaços privados, tornando-os acessíveis e transportando-os para a esfera pública. As reservas visíveis e ou visitáveis podem ser encaradas como um reflexo deste processo de comunicação, na medida em os museus não recorrem apenas às exposições permanentes, mas enfatizam diligências para a realização periódica de exposições temporárias, divulgando um maior número de objectos das colecções em reserva, concebendo novos sistemas expositivos mais didácticos e atractivos, 
fomentando a criação de experiências inovadoras, estratégias que convergem para um objectivo principal: a difusão do conhecimento.

Uma reserva visível e ou visitável permite que as pessoas possam visualizar um maior número de bens que à partida estariam longe dos seus olhares, por estarem em reserva. Esta iniciativa pode ser encarada como uma tentativa de democratizar a aproximação dos indivíduos aos objectos artísticos e culturais, já que na maior parte dos casos a grande percentagem do espólio dos museus acha-se em depósito, podendo também revelar um generalizado interesse crescente da sociedade pelo património. Trata-se de um conceito que tem vindo a ser usado com maior frequência entre a comunidade museológica (Thistle 1994; Hilberry 2013; Guillemard, 2010), todavia, é por vezes utilizado de modo erróneo. O termo reserva visível é empregue para caracterizar os projectos que permitem a visualização do espaço de reserva, no seu todo ou parcialmente, sem que haja um acesso directo ao recinto ou aos objectos armazenados.

No presente trabalho de investigação', que incide sobre condições de reservas, pretendemos realizar uma abordagem precisa em torno da temática das reservas visíveis e ou visitáveis implementadas em instituições museológicas. Tendo por panorama a realidade internacional, com especial incidência na situação europeia e com destaque para Portugal, numa vertente de conservação preventiva, também se inclui o levantamento das práticas em curso com vista à elaboração de um referencial de boas práticas neste domínio. Neste sentido, foi efectuada uma visita ao Schaulager (Schaulager Website: http://www.schaulager.org/), em Basileia na Suíça, como caso de estudo no âmbito da realidade europeia.

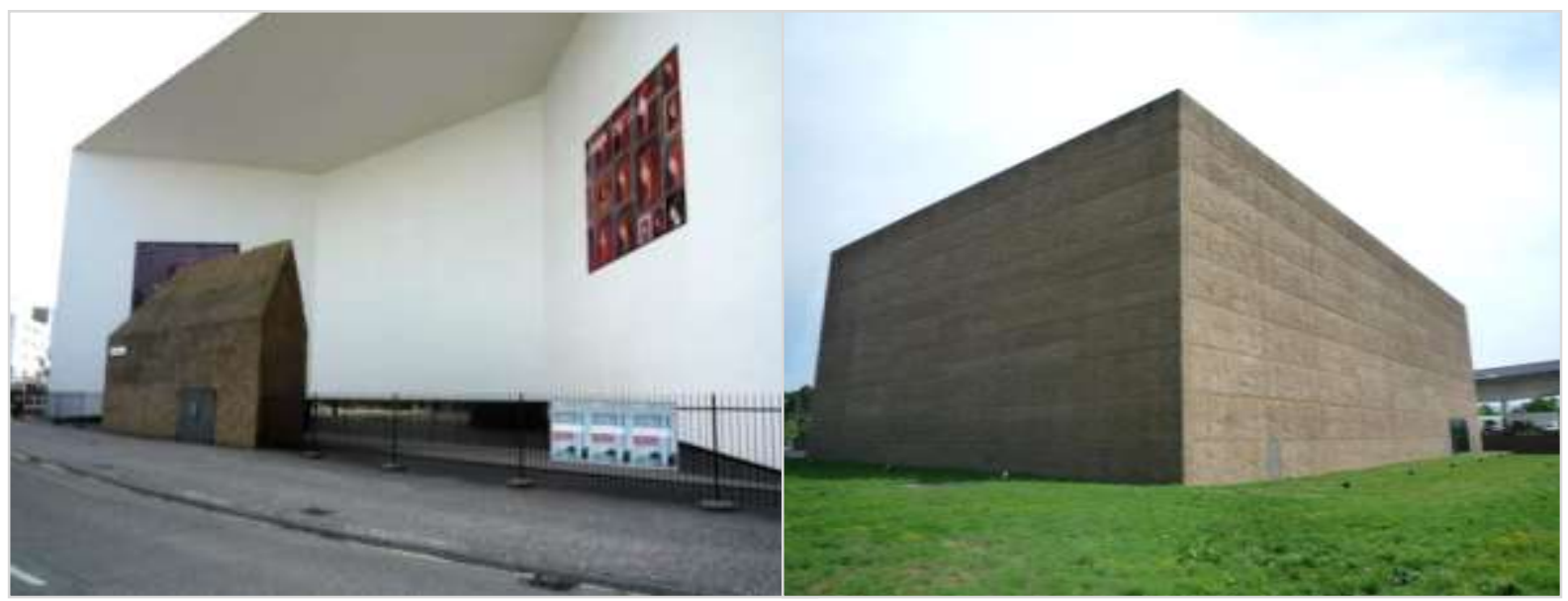

Figuras 1 e 2. Perspectiva da fachada, da parede norte e poente do Schaulager. OMaria Fernando Gomes.

O Schaulager é uma instituição privada, propriedade da Laurenz Foundation. A fundação está sediada em Basileia tendo sido constituída em 1999, por Maja Oeri ${ }^{2}$, para desenvolver o projecto de albergar a colecção arte contemporânea da Emanuel Hoffman Foundation ${ }^{3}$. Este caso de estudo tem por génese uma instituição dedicada à arte contemporânea, à sua conservação, pesquisa e divulgação, que teve necessidade de criar um edifício para albergar o seu espólio. A selecção deste caso justifica-se pela referência de qualidade e inovação que está na base da conceptualização desta reserva. 


\section{Tipologia das Coleções}

A Emanuel Hoffman Foundation, apenas está direccionada para as artes moderna e contemporânea. Possui na sua colecção obras de mais de 160 artistas, dos quais fazem parte peças de Salvador Dalí, Pablo Picasso, Paul Klee, Miró, Max Ernest ou Balthasar Burkhard. As obras de arte estão distribuídas pelas categorias de pintura, desenho, escultura, projectos de vídeo, filmes e instalações.

\section{O Percurso para a "Criação" do Conceito}

Partindo de preocupações no tocante à conservação e preservação das colecções, assim como da necessidade de se conceberem melhores infra-estruturas para o armazenamento das mesmas, énos apresentada uma solução pioneira para responder a esses propósitos. Maja Oeri optou pela projecção de um edifício de raiz, compreendendo uma solução combinada de espaço de reserva e área expositiva. Todavia há uma preocupação expressa com a componente do estudo, pesquisa, investigação e divulgação, pelo que o edifício foi concebido atendendo a preceitos para que a reserva fosse visível e visitável. Há, no entanto, diferenças quanto ao acesso dos investigadores, profissionais do património e do grande público e, consequentemente, na denominação utilizada.

A colecção de arte contemporânea da Emanuel Hoffman Foundation foi crescendo a um ritmo sistemático, em especial, a partir das duas últimas décadas do século XX. Sempre aberta às novas tendências, como a da arte minimalista e a da arte conceptual, a fundação incorpora no seio da sua colecção diversas obras de formatos incomuns e múltiplos suportes diversificados. Dada a grandeza da colecção, apenas uma pequena percentagem de trabalhos podiam ser expostos, no Kunstmuseum Basel ou no Museum für Gegenwartskunst Basel (http://www.schaulager.org/).

Todas as demais obras tinham que ser desmanteladas e acondicionadas em caixas, atendendo a parâmetros conservativos necessários ao seu armazenamento. Porém o volume de peças, tornava em termos logísticos, inviável o controle conservativo das obras e a preservação de alguns trabalhos, por não ser possível a detecção precoce de eventuais deteriorações resultantes da reacção entre distintos materiais empregues na realização de certas obras de arte contemporânea.

Estes fatos levantaram sérias preocupações a Maja Oeri, tornando-se imperativo encontrar uma solução assertiva e concretizável para este problema de grande complexidade. Por um lado, havia que responder às necessidades tradicionais de uma reserva $e$, por outro, às recentes especificidades impostas pelas produções artísticas actuais. A solução encontrada passou por ter as obras no espaço de reserva, devidamente instaladas, mas sem estarem embaladas, tornando-as observáveis e acessíveis em contínuo, tanto para fins da sua conservação, como também para o intento de estudo e investigação - e foi esta estrutura que se veio a denominar de Schaulager ${ }^{4}$.

A expressão introdutória que aparece na atualidade no website da instituição: «Not a museum, not $a$ tradicional warehouse. Schaulager - a place to see and think about art difrentlys (http://www.schaulager.org/) reforça a concepção inovadora deste imóvel que alberga uma nova estrutura museológica, originando, inclusive, um novo conceito de instituição de arte, afastando-se da ideia convencional de reserva e incorporando no mesmo edifício uma zona pública, onde decorrem exposições temporárias. O termo Schaulager está agregado à ideia de reserva visível para o público, sendo visitável para utilizadores profissionais e investigadores. 

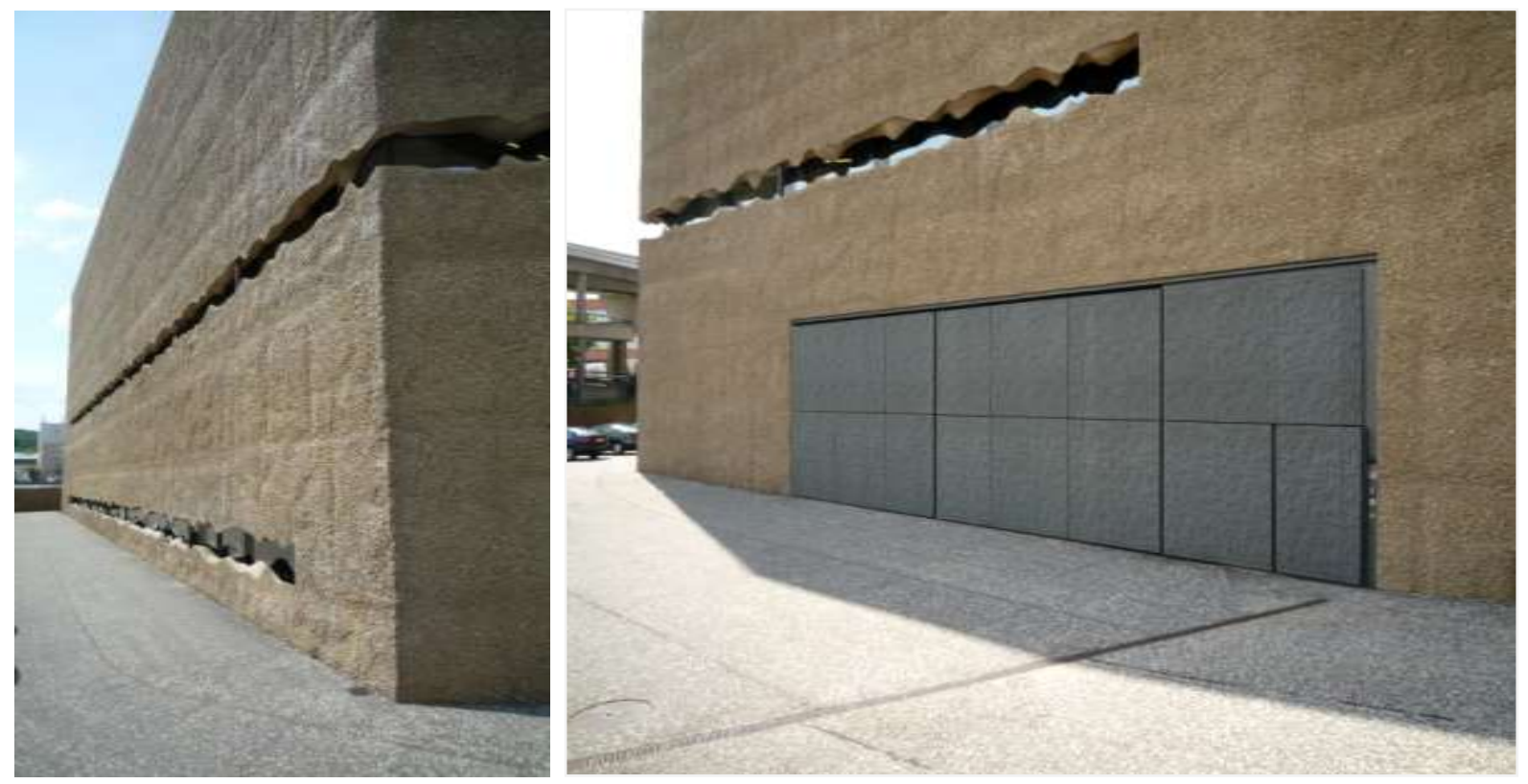

Figuras 3 e 4. Perspectiva da parede sul e sudoeste do Schaulager. OMaria Fernando Gomes.

\section{Projecto Arquitectónico}

A concepção do edifício vai para além dos estereótipos culturais do género, quebrando-os e transpondo-nos para uma realidade distinta do convencional.

O projecto para o Schaulager teve início em 1998-99, pelas mãos de Maja Oeri. Para além de ter criado a Laurenz Foundation como meio de financiamento da instituição, Maja Oeri também adquiriu um terreno na zona industrial de Basileia, para aí desenvolver a sua ideia. O projecto arquitectónico foi entregue ao gabinete de arquitectos suíços Herzog \& de Meuron. Os trabalhos de construção começaram em 2000. A inauguração deu-se a 24 de Maio de 2003, com uma retrospectiva da artista Dieter Roth (http://www.schaulager.org/).

Laureados com o prémio Pritzker em 2001, Jacques Herzog e Pierre de Meuron são uma dupla com uma trajectória de trabalhos prestigiados, realçando-se vários exemplos direccionados para o domínio cultural, dos quais se salientam: a Tate Modern; o Caricature and Cartoon Museum; o Küppersmühle Museum; o Tenerife Espacio de las Artes; o Young Museum; o Walker Art Center; o Museu Blau - Museu de Ciències Naturals de Barcelona; o Museum der Kulturen; o Parrish Art Museum e o Serpentine Gallery Pavilion.

O percurso arquitectónico de Herzog e Meuron é marcado pela capacidade de surpreender, transformando aquilo que à partida seria uma forma ordinária, condição ou material, em algo extraordinário (Jimenez 2001). As suas construções estão imbuídas de uma persistente essencialidade, de originalidade, de um cariz utilitário, de um desejo de funcionalidade, de materialidade e de pesquisa no domínio dos espaços e volumes. Desde sempre promoveram a busca do potencial da beleza através da fusão da função e do local (Jimenez 2001). Ao observarmos os distintos trabalhos temos consciência do rigor intelectual, do cuidado impresso em todos os detalhes, em particular na selecção dos materiais e na preocupação destes conferirem propriedades tácteis. O fascínio pela exploração das propriedades dos materiais, ainda que sejam 
matérias convencionais e a organização do espaço e do volume resulta em soluções arquitectónicas inovadoras.

\section{Localização geográfica}

Em termos de localização geográfica, o edifício tem a particularidade de estar erigido na periferia da cidade, dada a maior facilidade de se encontrarem terrenos disponíveis e com as dimensões necessárias para o desenvolvimento do projecto. O Schaulager está situado em Dreipitz/Münchenstein, aproximadamente a cinco quilómetros de Basileia.

\section{Organização espacial}

Jacques Herzog \& Pierre de Meuron, conceberam um armazém sob a forma de um corpo sólido poligonal, que assume as características de uma caixa escultórica [figura 5]. A fachada é a face marcante e pragmática do edifício [figura 1]. Esta é distinta de todas as outras, quer por questões geométricas, por ser facetada, quer pelo tipo de materiais empregues [figura 2]. Todo o exterior do imóvel é revestido com seixos encontrados no terreno, aquando do desaterro ${ }^{5}$, o que the confere um caracter agreste e rústico, à excepção da zona da entrada cujas paredes são pintadas de branco, e nas quais se destaca em cada um dos lados, um grande painel LED, com informações alusivas à instituição, apontando por contraponto, para uma faceta urbana e cosmopolita. Tratando-se de um armazém para o depósito de obras, houve especial preocupação com a quantidade de pontos de luz natural, pelo que estes se limitam a uma parte da parede da entrada envidraçada, que difunde a luz pelo interior do edifício e a dois pequenos rasgos horizontais, de formato serpenteante envidraçados, visíveis em duas das faces exteriores do edifício que correspondem a zonas administrativas e de serviços, e que não têm qualquer conexão com a zona de armazenamento [figuras 3 e 4].

A entrada é antecedida por um átrio e por um pequeno edifício com o tecto em duas águas construído com materiais idênticos aos do edifício principal [figura 6]. As portas exteriores de acesso são em metal perfurado com acabamento em tinta galvanizada, formando uma superfície ondulada, simulando a textura das paredes. O hall de entrada possibilita uma perspectiva genérica da construção, revelando a distribuição espacial por pisos [figuras 7 e 9]. Neste nível e no inferior encontram-se alguns serviços, ocorrem as exposições temporárias e estão depositadas as duas instalações permanentes de Katharina Fritsch e de Robert Gober.

Os três pisos superiores do Schaulager estão direccionados para o depósito das obras de arte [figuras 8 e 11]. Existem três tipologias de unidades de armazenamento (pequena, média e grande), se bem que as paredes podem ser adaptadas, ajustando-se a volumetria do espaço em função das dimensões das peças. Importa realçar que apesar da disposição cénica das obras, a entrada em cada uma das boxes pressupõe a passagem por uma porta [figuras 10]. Mediante as características das obras, como acontece com as de arte multimédia e digital, localizadas no último piso superior, as dimensões das portas podem ir até ao tecto, de forma a privilegiar a total escuridão das dependências. Este é um método evasivo para reduzir a entrada de luz. As portas apresentam-se em estrutura metálica pintada, com calhas deslizantes. Os pavimentos são distintos consoante estamos na área de reserva e na de exposição. Na primeira o chão é em betão armado, na segunda é em madeira.

Perspectivando o contínuo crescimento da colecção, a Laurenz Foundation deixou zonas de armazenamento livres, para dar azo a novas incorporações. 

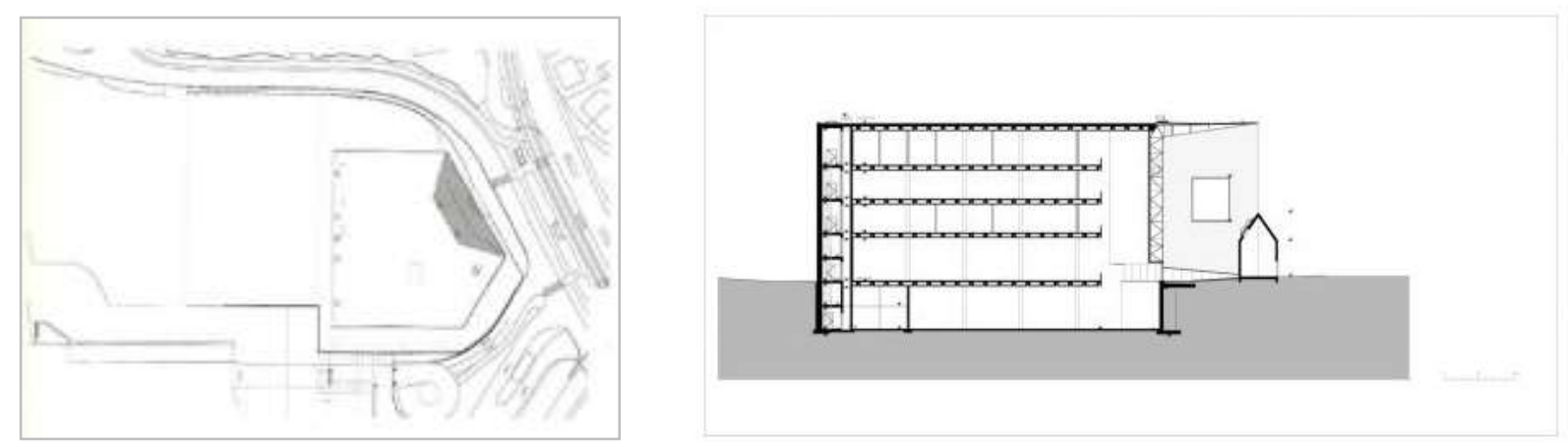

Figuras 5 e 6. Planta da zona de implementação do edifício; alçado sul; Fonte: Barreneche, 2005: 77.
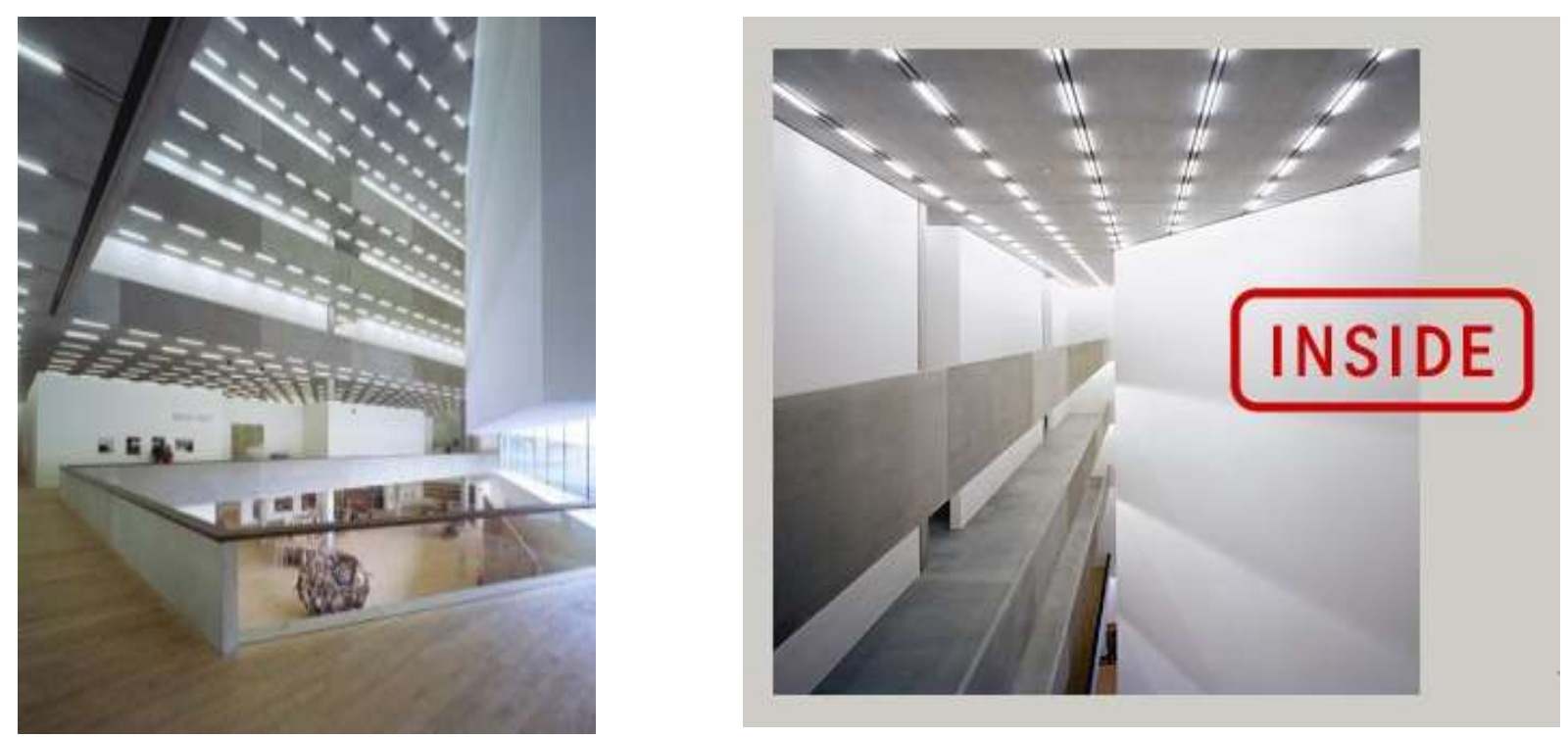

Figuras 7 e 8. Perspectiva do hall de entrada do Schaulager, aquando da exposição temporária: Roth Time, em 2003; OMonika Nikolic, Fonte: http://www.herzogdemeuron.com/index/projects/complete-works/151175/169-schaulager/IMAGE.htmI Vista da área de armazenamento do piso superior, Fonte:

http://www.schaulager.org/

\section{Superfícies}

A superfície total do imóvel é de $17500 \mathrm{~m}^{2}$. A área de reserva ocupa cerca de metade deste valor com $7250 \mathrm{~m}^{2}$. Os espaços vocacionados para as exposições temporárias têm $3650 \mathrm{~m}^{2}$. Os recintos destinados às instalações permanentes dos artistas Robert Gober e Katharina Fritsch preenchem, respectivamente, 260 e $390 \mathrm{~m}^{2}$. O departamento de manuseamento das obras de arte e workshops abrangem $800 \mathrm{~m}^{2}$, à semelhança dos sectores administrativos. O auditório regista $250 \mathrm{~m}^{2}$ ficando os $3100 \mathrm{~m}^{2}$ remanescentes para áreas técnicas e outras facilidades (http://www.schaulager.org/). 


\section{Equipamentos}

O Schaulager dispõe de áreas para a realização de eventos, workshops e exposições temporárias, de uma cafetaria, um auditório, assim como zonas de serviços técnicos, englobando estúdios para preparação de obras de arte, para montagem de exposições temporárias, para conservação e inclui sectores administrativos.

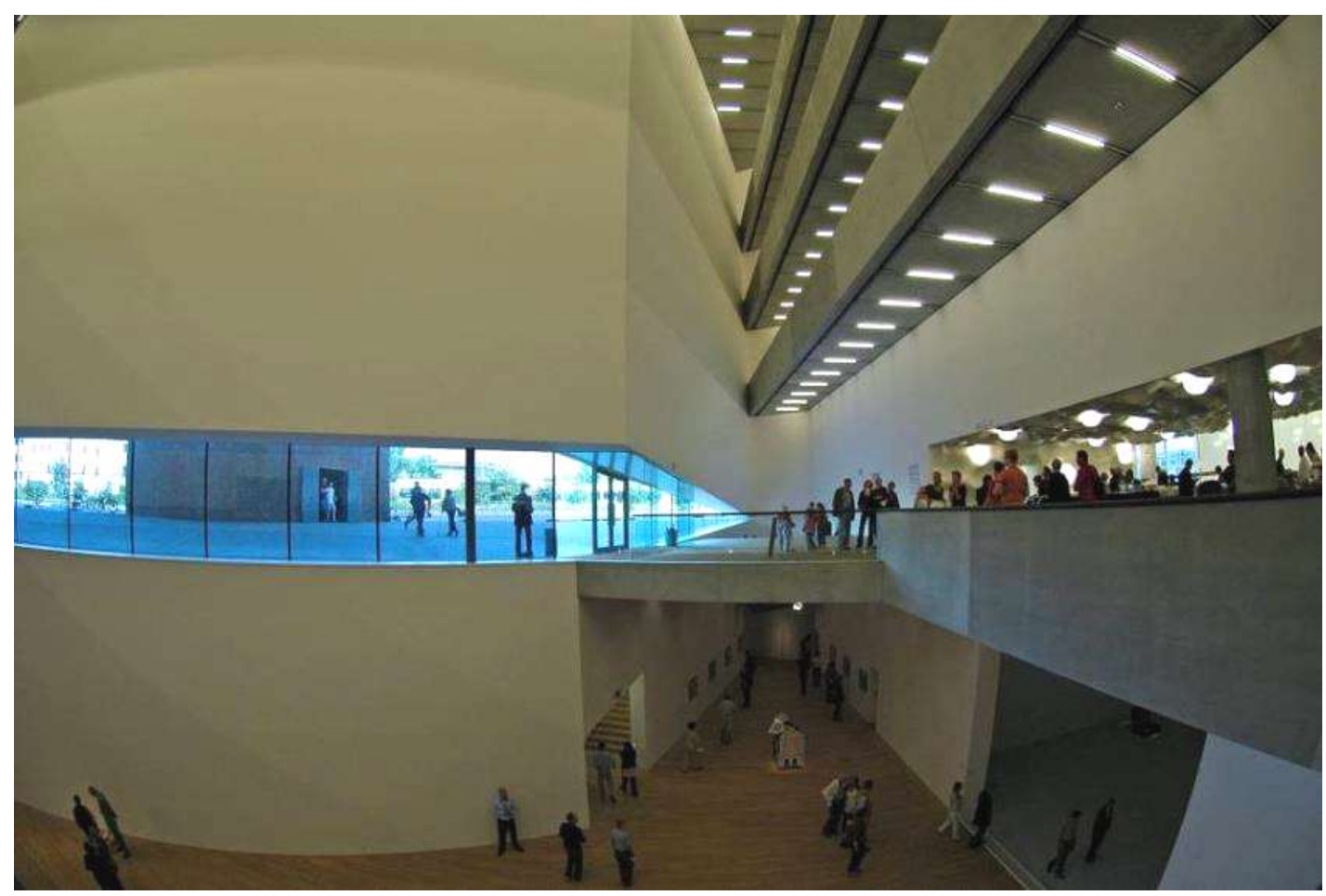

Figura 9. Perspectiva do interior do edifício - zonas de livre acesso do público, aquando de exposições temporárias; Fonte: http://architectuul.com/architecture/view_image/schaulager/9

\section{Conservação | Conservação Preventiva}

No domínio da produção de arte moderna e contemporânea é indiscutível a vulnerabilidade de certos trabalhos artísticos. Na opinião de Paolo Montorsi, as obras de arte contemporânea são muito mais frágeis que as antigas (Montorsi 2006:12), chegando Heinsz Althöfer a afirmar que a arte contemporânea degrada-se por si mesma (Althöfer 2006: 71).

A fragilidade e efemeridade deste tipo de trabalhos são muitas vezes decorrentes de um processo de experimentação constante dos conteúdos linguísticos, não apenas no âmbito das técnicas, através da adopção de práticas inovadoras, como dos materiais seleccionados. É frequente o uso de uma grande diversidade de materiais no mesmo objecto. Os materiais contemporâneos acabam por se tornar instáveis, sobretudo quando combinados, chegando a haver materiais autodestrutivos utilizados no momento da criação da obra, pelo que há obras que são criadas com o fim explícito de não durarem. A estrutura técnica de construção da obra de arte pode, de igual modo, ser determinante como foco de instabilidade. Porém, intervenções de conservação e restauro efectuadas sem uma caracterização rigorosa, quer da técnica do artista quer dos materiais 
empregues, também podem potenciar problemas. Todos estes factos levantam questões muito específicas e difíceis, do foro deontológico e inclusive legal.

O primeiro passo para a correcta conservação das obras de arte do século XX é conhecer os materiais e as técnicas empregues (Montorsi 2006:18). Todavia, hoje em dia não basta conhecer os materiais e dominar as técnicas de restauro para fazer um bom trabalho. Agora, também, há que entrar no universo intelectual, na filosofia do artista, posto que, de contrário, a intervenção partiria de um princípio erróneo (Althöfer 2006: 73). Isto representa um aspecto muito interessante e fascinante da arte; o transformar as obras em objectos, instrumentos de pensamento, de reflexão, referências sobre as quais podemos elaborar raciocínios, desenvolvê-los e alterá-los (Colombo 2006: 115).

A preservação do património cultural contemporâneo não pode ser considerada em termos de preservar a própria obra como objecto isolado, mas temos de preservar todo o sistema, todo o conjunto de características que são decisivas para o valor da obra de arte, o contexto de produção que estão na base da sua autenticidade (Jadzinska 2012: 83). O processo de conservação deverá então englobar uma análise dos aspectos tangíveis e intangíveis de cada trabalho, com vista à formulação de uma estratégia sustentada (Weyer 2006; Frasco 2009) .

As artes moderna e contemporânea requerem uma abordagem actualizada e inovadora para se conservarem e uma mudança de paradigma na preservação do património (Szmelter 2012: 30). Aparentemente, a atitude cognitiva mais eficaz no tratamento da arte contemporânea é tentar pensar à frente do nosso tempo e "manter sempre uma mente aberta" (Szmelter 2012: 31). É este raciocínio que está na base do Schaulager.

É usual as instituições museológicas depararem-se com problemas inerentes à colocação das obras, e à ambientação das mesmas ao espaço onde vão estar acondicionadas. A estabilização assume um papel determinante para se assegurar a salvaguarda dos bens culturais, a longo prazo. Salienta-se a importância do edifício estar adaptado às necessidades da colecção, contribuindo como um elemento aglutinador para a conservação das obras. Este pressuposto é transversal a todos os bens culturais, mas ganha destaque em colecções de arte moderna e contemporânea, dada a natureza específica das mesmas, onde predomina a diversidade de materiais e processos de composição.

No Schaulager foi adoptada uma metodologia de conservação preventiva simples, mas assertiva. $O$ método de armazenamento das obras e as directrizes das condições ambientais, constituíram dois desafios, tanto na área de exposição como de reserva, os quais foram interpretados pelos arquitectos com grande funcionalidade.

\section{Armazenamento das obras}

Nesta instituição foi criado um novo conceito de armazenamento de obras de arte contemporânea, que assegura as necessidades deste tipo de trabalhos. Há obras, que dadas as suas características, não podem estar expostas ou acondicionadas num espaço convencional e disso são exemplo os trabalhos de Katharina Fritsch e Robert Gober.

Isabel Friedli foi peremptória ao afirmar que o Schaulager se baseia num «simple concept». Pretende-se que haja sempre um acesso permanente às obras de arte, para que se consiga efectuar rotinas de inspecção com vista ao controlo das condições de conservação. Assim, se justifica 
plenamente a frase introdutória do website da instituição, aquando da criação: «Se a arte não é vista, ela morre. Se a arte não é conservada, ela deteriora-se». Neste sentido, as obras de arte estão armazenadas nas diferentes unidades de cada piso de depósito, como se estivessem nas salas de exposição de um museu ou uma galeria de arte contemporânea, chegando as peças a estar em contacto com o pavimento. A diferença substancial é que as obras não estão identificadas [figura 12 e 13]. A organização é realizada de acordo com critérios de nacionalidade, período, autor e dimensões.

Este método de trabalho assenta numa estratégia de conservação preventiva efectiva, tendo como ponto fulcral uma gestão vigilante e eficiente das obras.

\section{Condições ambiente}

Segundo Paolo Montorsi, a conservação de uma obra ao longo do tempo está determinada por três factores: os materiais que a constituem, a técnica de execução e as condições internas e externas do museu, edifício ou lugar em que se encontra a obra (Montorsi 2006: 13).

Os parâmetros das condições ambientais são idênticos e constantes em todo o imóvel, à excepção da área administrativa. Isto, dadas as características do edifício, já que no interior da construção, não existem barreiras arquitectónicas que conduzam à criação de microclimas e havendo apenas um único sistema de ventilação na área de armazenamento e expositiva. Os valores estão programados para os $50 \%$ de humidade relativa e os $20^{\circ} \mathrm{C}$ de temperatura. Dependendo das dimensões da unidade de armazenamento, existem dois ou mais pontos de aspiração do ar ao nível do tecto, o qual é filtrado e à posteriori, difundido por dispositivos localizados no solo, em número idêntico, através do sistema de ar condicionado. Este método tenta obstar o problema da deposição de pó nas obras. No que respeita ao sistema de iluminação, a opção recaiu na aplicação de calhas paralelas e lineares, com tubos de lâmpadas fluorescentes e filtros anti-radiação ultravioleta. Cada andar de armazenamento possui um quadro eléctrico digital que fornece informações detalhadas quanto ao sistema de iluminação geral daquele piso, permitindo acender, por exemplo, apenas as luzes dos corredores ou de uma única unidade de depósito pretendida, sem necessidade de acender a totalidade das lâmpadas. Isto é uma grande vantagem não apenas em termos conservativos, como de eficiência energética $e$, consequentemente, de encargos económicos.
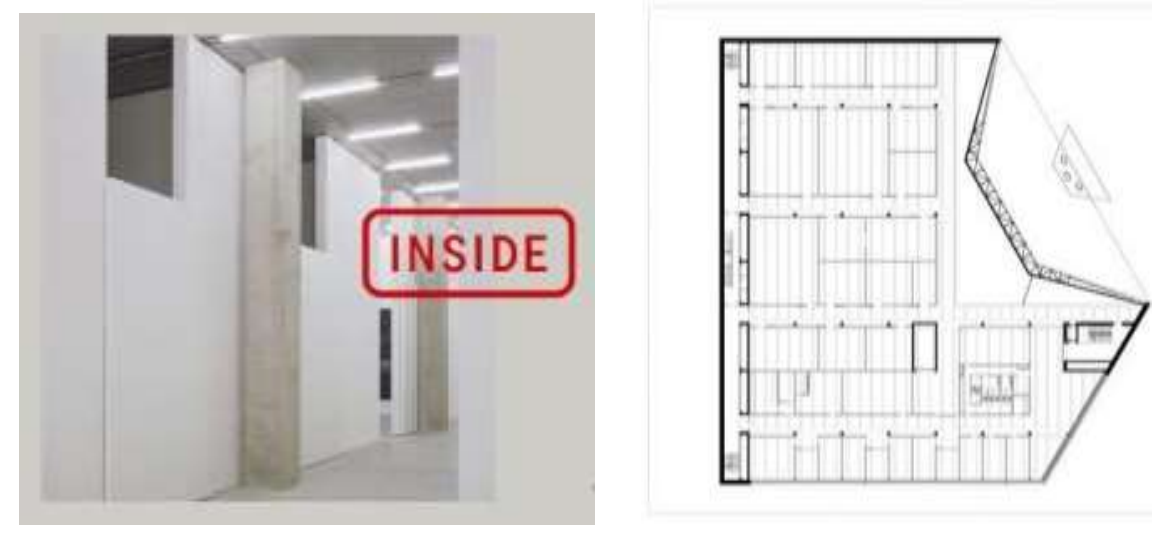

Figura 10, 11. Perspectiva exterior de algumas das unidades de armazenamento, Fonte: http://www.schaulager.org/. Planta de um dos pisos de reserva, Fonte: Barreneche 2005: 77. 


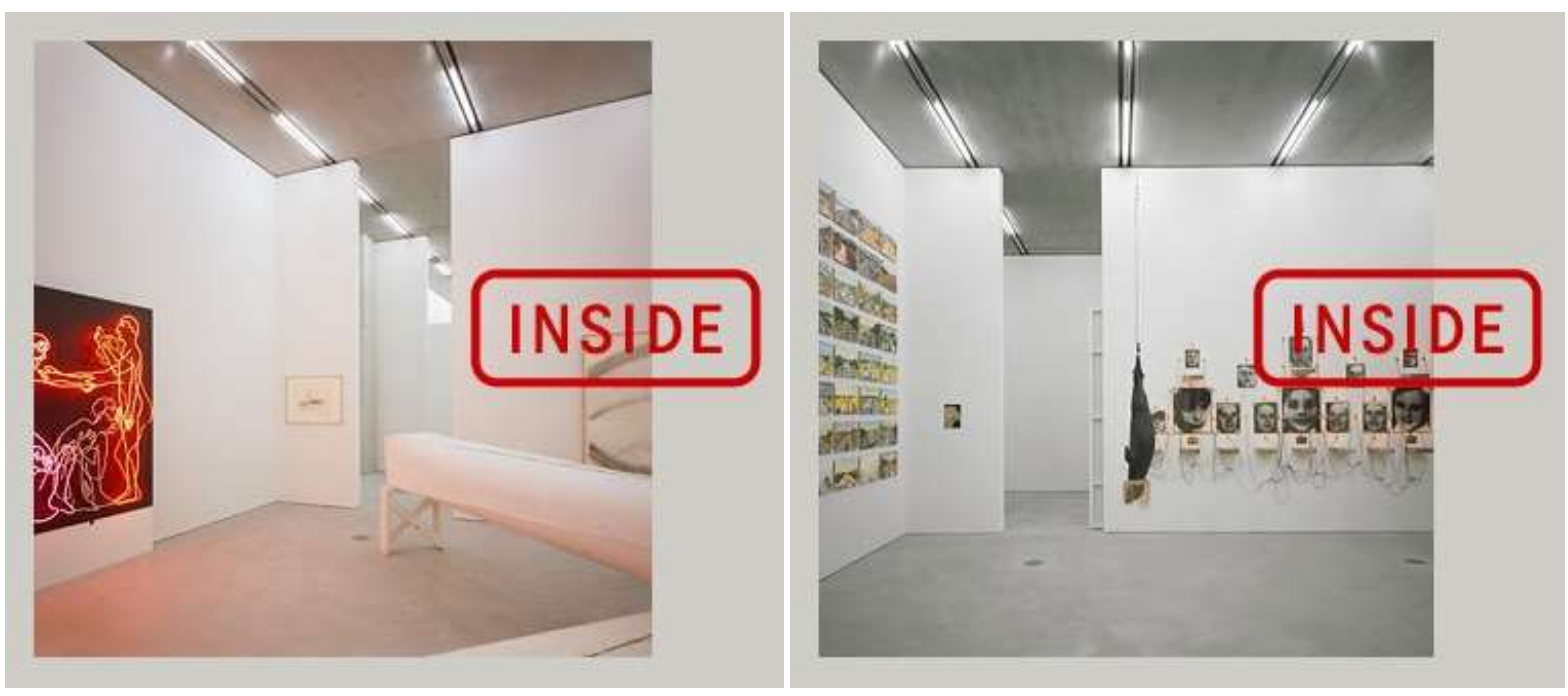

Figuras 12, 13. Vista do interior de duas das unidades de armazenamento no Schaulager. Fonte: http://www.schaulager.org/.

\section{Sistema de inventariação |Mediação}

Nos compartimentos de depósito do Schaulager não existe qualquer tipo de informação ou sistema de inventariação que nos permita identificar as peças. Para uma organização interna, apenas os corredores de cada andar estão identificados por letras e a cada unidade corresponde uma numeração. Em termos de mediação, esta função fica a cargo de um técnico, por norma um curador, que contextualiza toda a génese desta instituição e todo o percurso desenvolvido até aos dias de hoje, aos visitantes que se deslocam à reserva.

\section{Condições de Acesso}

Antes de programarmos uma visita é necessário solicitar uma autorização prévia, embora tenhamos a possibilidade de efectuar o pedido de visita individual ou em grupo, online, no site do Schaulager, expondo o projecto de investigação e os objectivos da visita.

Uma vez chegados ao destino, é com grande facilidade e rapidez que nos deslocamos por meio de transportes públicos. Na cidade de Basileia, apanhamos o metro de superfície em direcção a Dreipitz/Münchenstein e saímos na paragem Schaulager, mesmo à porta do imóvel.

O Schaulager é passível de ser visitado pelo grande público num período específico do ano, aquando da realização da exposição temporária anual, que decorre entre os meses de Primavera e Verão. A duração da exposição é variável, podendo chegar aos seis meses. Nesta época, as pessoas interessadas podem visitar e circular livremente pelo lounge, cafetaria ${ }^{6}$ e pelas demais áreas onde decorre a exposição temporária, dentro do horário estipulado. A Laurenz Foundation ainda abre as suas portas em ocasiões especiais, em certos eventos, e faculta a visualização de duas obras emblemáticas da colecção - as instalações permanentes de Katharina Fritsch e Robert Gober. Elas possuem um carácter mediador para os visitantes, possibilitando a percepção da dinâmica do conceito deste armazém, já que as obras estão expostas à semelhança das demais, nas diversas salas de depósito. A única excepção é que estas estão identificadas através de uma pequena placa 
localizada à entrada de cada uma das salas. Contudo, o público não pode aceder ao espaço de reserva que está vedado, ainda que de uma maneira implícita ${ }^{7}$. As reservas são visitáveis, durante todo o ano, embora se restrinja o acesso aos investigadores e especialistas.

Importa salientar que a acessibilidade para pessoas com mobilidade reduzida foi bem pensada, não existindo barreiras arquitectónicas.

\section{Conclusão}

A visita ao Schaulager permitiu consolidar a ideia de que esta instituição constitui uma referência na abordagem do tema das reservas museológicas. Trata-se de um exemplo de sucesso. Afirma-se pela inovação no panorama museológico europeu em termos conceptuais, tanto no domínio do conceito em si (de reserva visível), como no da adaptação do desenho arquitectónico aos objectivos, chegando a ser pioneiro no modo de acondicionamento das obras de arte moderna e contemporânea, uma vez que a natureza das suas colecções foi determinante para todo o projecto.

Esta instituição define um balanço, significativamente positivo, na articulação e na gestão de conflitos de interesses entre as funções primordiais de um espaço de reserva, vocacionado para a conservação e investigação do espólio e o facto desse mesmo local estar mais acessível ao público, com todos os condicionalismos daí inerentes.

A análise deste caso de estudo dá-nos a conhecer uma opção inventiva para o problema dos métodos de preservação das obras, marcada pela dualidade da relativa simplicidade da resolução prática, em contraponto com a complexidade cognitiva que levanta. O projecto no seu todo "obriga-nos" a um processo de reflexão. Da observação in loco, somos conscientemente questionados sobre a necessidade de haver uma reinterpretação do papel dos museus, em concreto dos que possuem colecções de arte contemporânea, quebrando o usual contraste sectorial do mundo da exposição e das reservas. A linguagem conceptual implementada influencia a articulação e a nossa percepção da arte, sendo um método distinto de transmissão, recepção e difusão do conhecimento. Há uma reorientação do método de trabalho; a introdução de novas perspectivas e de novos princípios metodológicos. Esta estratégia direcciona a nossa atenção para o campo da conservação, dando destaque à importante interacção entre o conservador e a obra de arte.

\section{Notas}

[1] Este artigo insere-se no projecto de Doutoramento da autora, cujo título da dissertação é: "Conservação Preventiva: Condições de Reserva», no âmbito do Doutoramento em Conservação de Pintura da EA|UCP.

[2] É a actual presidente da Emanuel Hoffman Foundation, sendo descendente de Maja HoffmannStehlin.

[3] A Emanuel Hoffman Foundation, sediada em Basileia, foi criada em 1933, por Maja Hoffmann-Stehlin, (1898-1989),com o propósito de enaltecer a predilecção do falecido marido pela arte contemporânea, gosto que partilhava com ele.

[4] A tradução para português quer dizer armazém visível, ou de acordo com a opinião de Luís Casanovas "armazém para olhar" (Casanovas, 2004:17).

[5] Facto que contribuiu para uma maior estabilidade das condições ambientais existentes no interior. 
[6] A zona da cafetaria tem a particularidade de ter uma parede envidraçada, direccionada para o corredor das áreas técnicas, permitindo a visualização de alguns procedimentos habituais de gestão museológica, como assistir ao transporte de uma obra de arte.

[7] A comunicação entre os diferentes pisos da edificação pode ser realizada por ascensor, porém, no interior do elevador existe um sistema de segurança que restringe o acesso de qualquer pessoa estranha à instituição aos pisos onde estão depositadas as obras.

\section{Bibliografia}

ALTHÖFER, H. (2006). "La restauración del arte moderno e contemporáneo". In Conservar el arte contemporáneo. Righi, Lídia (coord.)San Sebastian, Editorial Nerea, S. A. 71-78.

CASANOVAS, L. E. (2004). "SCHULAGER: Um museu muito especial”, Boletim da Rede Portuguesa de Museus, 11: 17-18.

COLOMBO, G. (2006). "Instalaciones y passado remoto". In Conservar el arte contemporáneo. Righi, Lídia (coord.). San Sebastian: Editorial Nerea, S. A., 113-120.

GUILLEMARD, D. (2010). "Variations sur le thème de la réserve visitable". In Conservation restauration des biens culturels, 28: 3-8.

HERZOG \& de Meuron Website. http://www.herzogdemeuron.com [Consultado: 8.01.2013].

HILBERRY, J.D. Behind the Scenes: Strategies for Visible Storage. http://www.aamus.org/pubs/mn/MN_JA02_VisibleStorage.cfm [Consultado: 9.01.2013].

HOOPER-GREENHILL, E. (1999). "Communication in theory and practice". In The educational role of the museum. HOOPER-GREENHILL, Eilean (edit.). London: Routledge, 28-43.

HOOPER-GREENHILL, E. (2000). "Changing values in the art museum: rethinking communication and learning" International Journal of Heritage Studies. Hooper-Greenhill, E. (edit.). London: Routledge, 6: 9-31.

JADZINSKA, M. (2012). "Back to the future: Authenticity and its influence on the conservation of modern art". In Innovative approaches to the complex care of contemporary art. Szmelter, Iwona (edit.). London: Archetype Publications Ldt.: 82-99.

JIMENEZ, C. (2001). Essay: The architecture oh Jacques Herzog and Pierre de Meuron. http://www.pritzkerprize.com/2001/essay [Consultado: 2.01.2013].

MONTORSI, P. (2006). "Una teoria de la restauración del arte contemporâneo". In Conservar el arte contemporáneo. Righi, Lídia (coord.). San Sebastian: Editorial Nerea, S. A.:11-51.

SCHAULAGER Website. http://www.schaulager.org/ [Consultado: 8.01.2013].

SZMELTER, I. (2012). "An innovative complex approach to visual art preservation". In Innovative approaches to the complex care of contemporary art. Szmelter, Iwona (edit.). London: Archetype Publications Ldt., 10-33.

THE PRITZKER Architecture Prize Website. http://www.pritzkerprize.com/. [Consultado: 2.01.2013].

THISTLE, P. C. (1994). "Visible storage for the small museum”. In KNELL, S. ed. Care of collections. London: Routledge: 187-196.

WEYER, C. (2006). "Restoration theory applied to installation art". In Beiträge zur Erhaltung von Kunst- und Kulturgut. VDR - Verband der Restauratoren, 2: 40-48.

FRASCO, L. (2009). The Contingency of conservation: Changing methodology and theoretical issues in conserving ephemeral contemporary artworks special reference to installation art. Pennsylvania: Visual Studies Department, University of Pennsylvania, Thesis Program. 


\section{Agradecimentos}

Prof. Doutora Eduarda Vieira (orientadora); Doutor Engenheiro Luís Efrem Elias Casanovas e Prof. Doutora Ana Calvo Manuel (coorientadores); Isabel Friedli, Curadora do Schaulager; Fundação para a Ciência e Tecnologia (FCT).

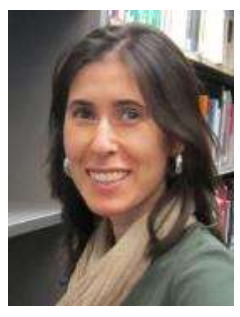

Maria Fernando Gomes

mariafernandogomes@gmail.com

Doutoranda em Conservação de Pintura na Escola das Artes da Universidade Católica Portuguesa - Centro Regional do Porto, Portugal. Tema de Dissertação: «Conservaçäo Preventiva: Condiçōes de Reserva». Bolseira de doutoramento da Fundação para a Ciência e Tecnologia (FCT). Membro colaborador do CITAR - Centro de Investigação em Ciência e Tecnologia das Artes, Escola das Artes, Centro Regional do Porto da Universidade Católica Portuguesa, na linha de investigação "Estudo e Conservação do Património Cultural", na área temática de "Conservação de Bens Culturais".

Licenciada em Arte, Conservação e Restauro, com especialização em Escultura e Talha, pela Escola das Artes da Universidade Católica Portuguesa - Centro Regional do Porto.

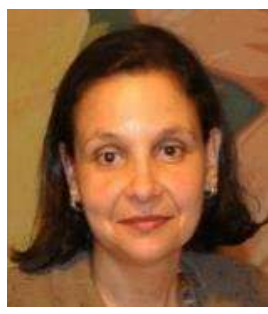

\section{Eduarda Vieira}

evieira@porto.ucp.pt

Doutorada em Conservação e Restauro do Património Histórico-Artístico pela Universidade Politécnica de Valência. Mestre em Recuperação do Património Arquitectónico e Paisagístico pela Universidade de Évora. Docente do Departamento de Arte, Conservação e Restauro da Escola das Artes da Universidade Católica Portuguesa- pólo regional do Porto. Coordenadora científica da área de Conservação de Bens Culturais do CITAR. Coordenadora do Doutoramento e do Mestrado em Conservação de Bens Culturais e da Pós Graduação em Conservação Preventiva da UCP.

Artículo enviado el 10/01/2013

Artículo aceptado el 23/05/2013 


\title{
Sobre la importancia de las tareas de mantenimiento en las vidrieras
}

\author{
Fernando Cortés Pizano
}

\begin{abstract}
Resumen: Uno de los principales factores de deterioro del patrimonio arquitectónico es la falta de supervisión y mantenimiento regulares. El primer paso necesario para detectar los daños surgidos en un edificio es la realización de inspecciones periódicas, cuyos resultados nos darán las pautas para la consiguiente ejecución de actuaciones de mantenimiento. Esta simple filosofía de prevención e intervención constante es el método más económico para conservar nuestro patrimonio en buen estado. Si bien en España aún no hemos logrado desarrollar una política de conservación preventiva adecuada, en algunos países de Europa, especialmente en el Reino Unido, este tipo de actuaciones desempeña un papel muy importante.
\end{abstract}

Palabras clave: Vidrieras, mantenimiento, conservación preventiva, prevención, arquitectura, inspecciones periódicas.

\section{Sobre a importância das operações de manutenção em vitrais}

Resumo: Um dos principais factores de deterioração do património arquitectónico é a falta de supervisão e manutenção regular. O primeiro passo essencial para detectar os danos surgidos num edifício é a realização de inspecções periódicas, cujos resultados nos darão as pautas para a consequente execução de operações de manutenção. Esta filosofia simples de prevenção e intervenção constante é o método mais económico para conservar o nosso património em bom estado. Se bem que em Espanha ainda não conseguimos desenvolver uma política de conservação preventiva adequada, em certos países da Europa, sobretudo no Reino Unido, este tipo de acções desempenha um papel muito importante.

Palavras-chave: Vitrais; manutenção; conservação preventiva; prevenção; arquitectura; inspecções periódicas.

\section{On the importance of stained glass windows maintenance}

\begin{abstract}
One of the main factors of deterioration of architectural heritage is the lack of supervision and regular maintenance. Regular inspections are a necessary first step to detect any damage in a building. The results of these inspections will give us guidelines for carrying out subsequent maintenance actions. This simple philosophy of prevention and constant intervention is the most economical method to preserve our heritage in good condition. While in Spain we have not yet develop a proper preventive conservation policy, in some European countries, especially in the UK, this type of actions plays a very important role.
\end{abstract}

Keywords: Stained glass, maintenance, preventive conservation, prevention, architecture, regular inspections.

\section{Introducción}

En este artículo se discute la importancia de las tareas regulares de mantenimiento en edificios históricos, con especial énfasis en las vidrieras. Asimismo se comentan los casos particulares del Reino Unido y España, dos países con un gran patrimonio arquitectónico y vidriero pero con políticas de actuación diferentes en este ámbito. Durante las últimas décadas, numerosos textos sobre conservación y restauración han reflejado la gran importancia de estas acciones como la 
forma más efectiva de frenar el deterioro de los edificios. La misma Carta de Atenas de 1931 propone: "... la institución de obras de mantenimiento regular y permanente para asegurar la conservación de los edificios". En el Reino Unido, donde esta filosofía es muy importante, existen varias catedrales con un equipo propio de profesionales, generalmente canteros y vidrieros, dedicado exclusivamente a realizar intervenciones en dicho edificio. En estos templos el trabajo es constante y se apuesta por un mantenimiento ininterrumpido como forma de frenar el deterioro y evitar, de esta forma, restauraciones más profundas. Por lo que respecta a las vidrieras, las catedrales de York, Canterbury, Lincoln y Salisbury disponen, desde hace ya muchos años, de un equipo propio de vidrieros. Sin embargo, esta práctica no es frecuente en el resto de Europa y, hasta donde yo conozco, solamente existen talleres propios en las catedrales de Erfurt y Colonia, en Alemania y en la de Nidaros en Trondheim, Noruega. En lo que respecta a España, a pesar del importante patrimonio vidriero existente, no contamos con ningún taller de este tipo [figura 1].
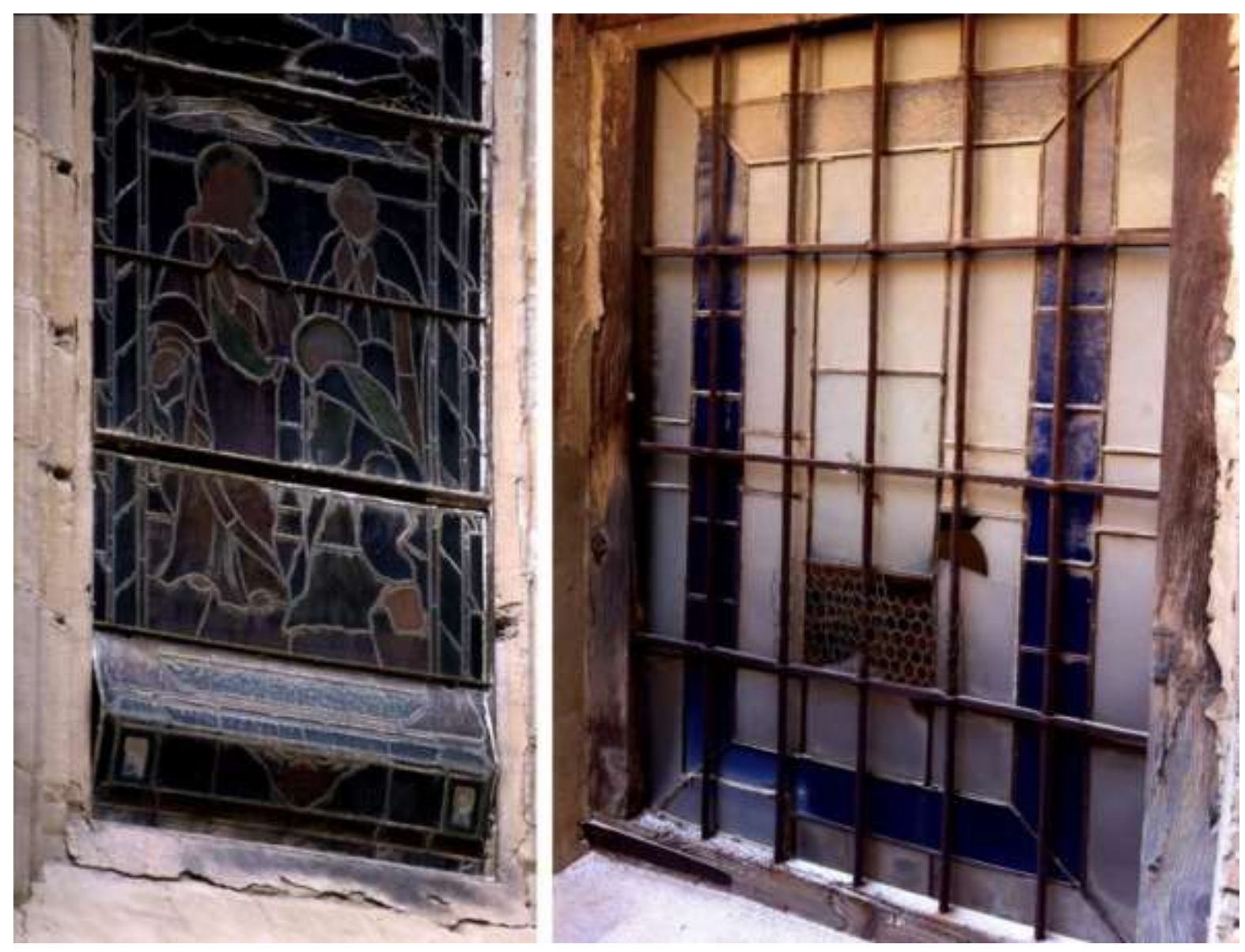

Figura 1. Pérdida de estanqueidad en las vidrieras. Izquierda: catedral de Logroño; derecha: catedral de Valencia.

\section{La filosofía del mantenimiento regular}

La filosofía del mantenimiento regular se basa en la aplicación de la conocida máxima: mejor prevenir que curar. Como es bien sabido, las causas principales del deterioro en un edificio son el envejecimiento natural del mismo, la mala calidad de los materiales y métodos constructivos, las 
reparaciones inadecuadas y la falta de tareas de mantenimiento. Asimismo, todos los elementos muebles y artísticos vinculados al edificio, tales como retablos, pinturas murales, vidrieras, órganos, mobiliario, sillerías, cuadros, materiales de archivo, etc, se ven afectados por estos mismos factores. La solución a este problema pasa por la aplicación de políticas de prevención adecuadas, basadas en frecuentes rutinas de supervisión. En una primera fase, se inspecciona el edificio con el fin de analizar su estado de conservación, detectar los problemas existentes y evaluar su importancia. En una segunda fase, se procede a una actuación directa, en la que se reparan o restauran las alteraciones detectadas. Obviamente, ambas intervenciones han de ser realizadas por profesionales competentes [figura 2].
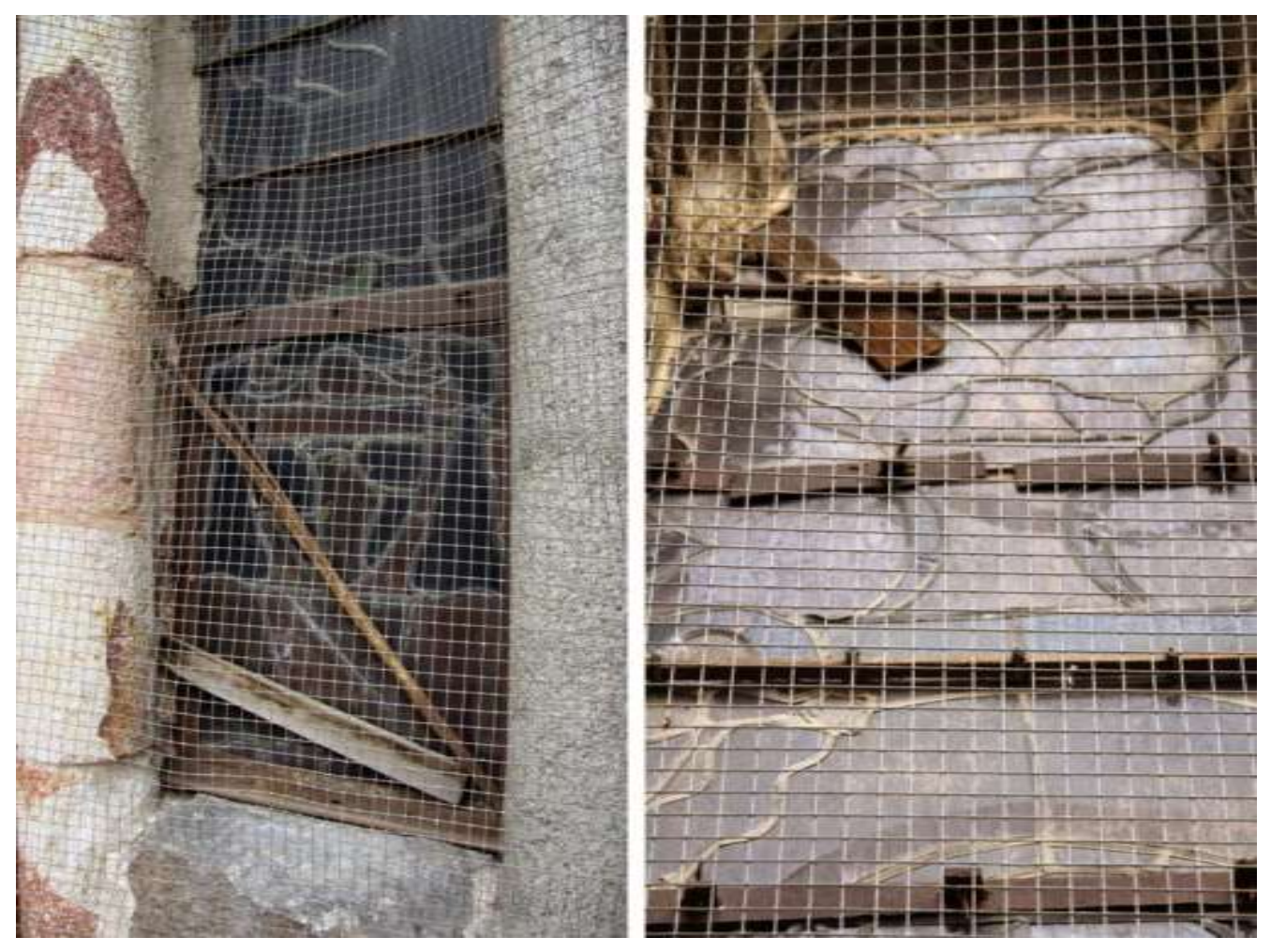

Figura 2. Mal estado de elementos metálicos, morteros y masillas en algunas vidrieras de la catedral de Ávila.

\section{Políticas de mantenimiento en el Reino Unido}

Este sistema de mantenimiento, acompañado de la recuperación de oficios tradicionales directamente vinculados a la arquitectura y construcción de este tipo de edificios, no es una idea exclusiva del Reino Unido (Neza Cebron 2008), si bien posiblemente sea éste uno de los países donde esté más implantada. Uno de los mejores ejemplos que ilustran esta actitud lo podemos ver reflejado en la Sociedad para la Protección de los Edificios Antiguos (The Society for the Protection of Ancient Buildings - SPAB). Se trata de una sociedad independiente, fundada en 1877 por William Morris, entre otros, y es posiblemente una de las más antiguas del mundo dedicada a la conservación de patrimonio. Nació con el objetivo de contrarrestar la "restauración" altamente destructiva de edificios medievales que llevaban a cabo muchos arquitectos victorianos. El propio William Morris lo expresaba de la siguiente manera en el Manifiesto fundacional de la SPAB: 
"...La falta de mantenimiento es uno de los motivos principales por los que los edificios antiguos se deterioran. La realización de tareas rutinarias de mantenimiento de forma periódica ayuda a proteger la fábrica de nuestros edificios históricos y garantiza su supervivencia para que puedan ser disfrutados por las generaciones futuras. EI mantenimiento es asimismo la manera más práctica y económica de conservar los edificios. Mediante la realización de un mantenimiento básico los gastos de las reparaciones importantes pueden a menudo ser evitados o al menos pospuestos..." (http://www.spab.org.uk/what-is-spab-/the-manifesto/).

La filosofía original de la SPAB, influida por los escritos de John Ruskin (1819-1900), sigue totalmente vigente hoy día y no puedo más que compartir sus principios fundamentales: el mantenimiento regular es la forma más práctica y económica de preservación, protección en lugar de restauración, es decir, evitar el deterioro mediante el cuidado diario. Si bien esta sociedad es probablemente la que mejor representa esta idea, existen en el Reino Unido otras muchas organizaciones afines cuyo objetivo es también el estudio, difusión, protección, salvaguarda o conservación de edificios o conjuntos históricos ${ }^{2}$ (Crofts 2012). Una gran mayoría de estas organizaciones son de carácter independiente, privado y caritativo, sin ánimo de lucro, y funcionan mediante subvenciones y aportaciones procedentes de diversas fuentes, la mayoría de ellas privadas, por lo que no dependen del dinero público para su funcionamiento. Todas estas organizaciones necesitan de un departamento de recaudación de fondos para poder sobrevivir. Las aportaciones económicas son de procedencia muy diversa pero sin duda las contribuciones privadas, tanto en forma de dinero como de tiempo y de trabajo voluntario, son muy importantes. En el caso de edificios religiosos, las ayudas de los propios miembros de la comunidad religiosa de cada parroquia son especialmente valiosas. Existe asimismo una gran cantidad de publicaciones y recursos disponibles en internet, a menudo gratuitos. Algunos de estos documentos son de carácter general (www.maintainourheritage.co.uk/further_reading.htm o www.hbc.org.uk/publications/stitch/stitch.html) y otros tratan de aspectos más concretos como es el caso de las vidrieras (wwwwhistoricscotland.gov.uk/informguide-historicglass.pdi).

\section{Pautas para las tareas de inspección de edificios}

Para la ejecución de inspecciones es importante disponer de un protocolo en el que se recojan las diferentes situaciones y elementos del edificio que deben ser supervisados, especificando su estado y la necesidad o urgencia de las posibles intervenciones. Si bien este listado puede ser muy amplio, citamos aquí, con ligeras variaciones, las recomendaciones de la SPAB (http://www.spabfim.org.uk/data/files/pages/maintenance_checklist_v3.pdf) para la realización de inspecciones en edificios históricos:

- Sistemas de conducción y evacuación del agua de lluvia. Comprobar canalones, bajantes, desagües y alcantarillado para detectar posibles filtraciones u obstrucciones.

- Tejados. Tanto la estructura portante de los tejados, como sus materiales de recubrimiento (tejas, paja, azulejos, etc.) han de ser cuidadosamente revisados.

- Uniones. Los orificios, grietas, fisuras u otros posibles defectos existentes en zonas de unión de dos materiales pueden permitir el paso del agua hacia el interior.

- Muros. Comprobar las juntas de mortero y los enlucidos de recubrimiento en busca de signos de deterioro. 
- Niveles de tierra. Evitar la acumulación de tierra en la base de los muros, ya que ésta podría retener la humedad y afectar a la impermeabilización del edificio.

- Ventilación. Asegurarse de que las rejillas de salida de aire y los sistemas de ventilación estén despejados y en perfecto funcionamiento.

- Plantas. Las plantas y arbustos pueden embellecer los edificios pero también pueden dañar los muros o bloquear conducciones de agua y alcantarillados.

- Instalaciones. Es necesario comprobar regularmente el funcionamiento de las instalaciones de agua, calefacción, fontanería, electricidad, gas, climatización, etc.

- Sistemas de calefacción o aire acondicionado. Un mal funcionamiento de estas instalaciones puede producir un brusco y excesivo calentamiento del edificio durante cortos periodos de tiempo.

- Sistemas de ventilación natural (o forzada) del edificio. La correcta ventilación de un edificio es esencial para garantizar una adecuada regeneración del aire y evitar la formación de humedades.

- Calidad del aire en el edificio (frecuencia y número de visitantes, combustión excesiva de velas, tráfico rodado en las cercanías, etc.).

\section{Los talleres de restauración de la catedral de Lincoln}

La catedral de Lincoln, perteneciente a la Iglesia Anglicana, es uno de los edificios góticos más importantes del Reino Unido ${ }^{3}$. Desde agosto de 2012 trabajo como restaurador de vidrieras en esta catedral, donde ya desempeñé el mismo trabajo entre 2004 y 2005. Aquí formo parte de un equipo de profesionales dedicados exclusivamente a este edificio y cuyo objetivo es garantizar su buen estado general, lo que incluye elementos pétreos, ventanas y vidrieras, techos y tejados, sistemas de conducción y evacuación de aguas, etc. El equipo de trabajo de la catedral de Lincoln es uno de los más grandes del país y se compone en la actualidad de 12 canteros, 9 carpinteros, 4 restauradores de vidrieras, 4 plomeros, 2 conservadores de elementos pétreos, 2 personas encargadas del mantenimiento general, 2 albañiles, 1 pintor, 1 archivero y una gran cantidad de personal administrativo. Todos estos profesionales están contratados por la propia catedral de Lincoln, que funciona como una empresa privada en todos los sentidos. La mayoría de los contratos tienen una duración inicial de un año, con un periodo de prueba de tres meses, para posteriormente obtener un contrato permanente. El número de trabajadores puede variar según los diferentes proyectos en curso.

En estos talleres se fomenta el aprendizaje de los distintos oficios asociados al mantenimiento del edificio, siendo frecuente la presencia de estudiantes en prácticas o becarios, quienes en ocasiones pasan a formar parte de la plantilla regular. Los talleres están situados junto a la catedral, con el fin de facilitar el trabajo, evitar desplazamientos innecesarios y economizar gastos. El contacto y la cercanía con la fábrica es por tanto diario y cualquier problema o anomalía que pudiera suceder es detectado y reparado lo antes posible. Asimismo, el contacto y la colaboración entre los diferentes profesionales son constantes, lo que facilita enormemente el intercambio de ideas y la coordinación y ejecución de los trabajos comunes. Con este sistema de trabajo se termina por conocer a fondo el edificio, sus características y sus problemas, manteniendo una línea de 
intervención coherente a lo largo de los años y evitando así los diferentes enfoques y acabados que a menudo conllevan la participación de diferentes empresas externas de restauración.

Paralelamente a las tareas rutinarias de mantenimiento, se restauran de forma paulatina las vidrieras del edificio en función del Plan Director. En estos proyectos de restauración se siguen las pautas y procedimientos habituales, que incluyen la documentación preliminar, el desmontaje de la vidriera, su intervención en el taller y su montaje final. A menudo los vidrieros trabajamos en equipo con los canteros, los carpinteros y los restauradores de piedra. Asimismo, en proyectos importantes, como es el caso de intervenciones en vidrieras medievales, se cuenta con el asesoramiento de un comité de expertos.

Como hemos comentado más arriba, estos talleres no reciben generalmente subvenciones públicas, por lo que necesitan de fuertes ingresos para poder mantenerse. Excepto los talleres de Lincoln, que trabajan exclusivamente para la catedral, los otros talleres mencionados suelen asumir encargos externos como una forma de generar ingresos. Si bien podría pensarse que el montaje y mantenimiento de estos talleres propios es una inversión cara, la experiencia demuestra que a medio y largo plazo resultan ser una opción mucho más eficaz y menos costosa que el recurrir a contratas y subcontratas externas. Aparte de las numerosas donaciones privadas, ya comentadas, la catedral de Lincoln dispone de otros medios para general ingresos, tales como las campañas de difusión, la organización de eventos diversos como conciertos y festivales, la venta de entradas, las visitas guiadas a los tejados, las torres o los talleres, la venta general de todo tipo de artículos turísticos en la tienda y en la cafetería, participación en ferias y mercadillos, alquiler de espacios de la catedral para eventos públicos o privados, alquiler de las casas adyacentes a la catedral, patrocinio del público mediante la adopción de elementos del edificio como piedras o paneles de vidrieras, la venta de materiales originales y antiguos que no pueden ser reutilizados, como clavos y secciones de vigas de madera, etc. Asimismo, el uso de su propia cantera supone un ahorro considerable en el trabajo de los canteros. La idea principal subyacente es la de acercar la catedral a todos los estratos de la ciudadanía para lograr así que todos la valoren y se sientan involucrados en su conservación.

(http://www.roseregeneration.co.uk/media/Lincoln\%20Cathedral\%20Socio\%20Economic\%20Stud y.pdf).

\section{Políticas de mantenimiento en España}

Una vez explicado el funcionamiento de este tipo de talleres, resulta llamativo que esta iniciativa no sea más frecuente en ciertos edificios históricos españoles, donde se opta más bien por los concursos públicos y la contratación externa. En España las intervenciones en el patrimonio edificado discurren por otros derroteros en lo que respecta a las cuestiones económicas. La mayor parte del dinero necesario procede generalmente de aportaciones de carácter público (gobierno central y gobiernos autonómicos, provinciales o municipales), mientras que una parte menor procede de entidades privadas, tales como fundaciones, cajas de ahorros, compañías y empresas diversas, o de la propia Iglesia. En ocasiones se reciben fondos de la Comunidad Europea u otros organismos internacionales.

Desde hace muy pocos años existen en España las llamadas "Inspecciones Técnicas de Edificios" (ITE), mediante las cuales aquellos edificios utilizados principalmente como viviendas y de cierta antigüedad, entre 30 y 50 años, están obligados a pasar un control técnico regular. Las ITE vienen reguladas por el artículo 21 del Real Decreto-ley 8/2011 de 1 de julio y por las distintas Ordenanzas 
Municipales, que determinan las condiciones para las inspecciones (Castellano González 2007). Sería deseable hacer extensible esta ley, de forma clara, real y efectiva, al resto del patrimonio arquitectónico más antiguo ya que, hasta donde yo conozco, estas inspecciones obligatorias son totalmente inexistentes, y mucho menos en el campo de las vidrieras y otros elementos artísticos del edificio. Esto nos lleva a preguntarnos por qué nuestros edificios históricos más relevantes, donde el volumen de trabajo es enorme y constante, no disponen de un personal de mantenimiento en plantilla, como sucede en muchos edificios públicos o privados (polideportivos, hoteles, escuelas, etc.). Una posible respuesta es que para poner en marcha este tipo de proyectos es necesaria una valoración y apreciación profunda de nuestro patrimonio, tanto por parte de las instituciones públicas responsables como del gran público. A menudo el problema no es la falta de dinero en el país sino la dirección hacia la que ese dinero fluye, siendo evidente que la cultura en general y los bienes culturales en particular no suelen considerarse prioritarias [figura 3 y 4 ].
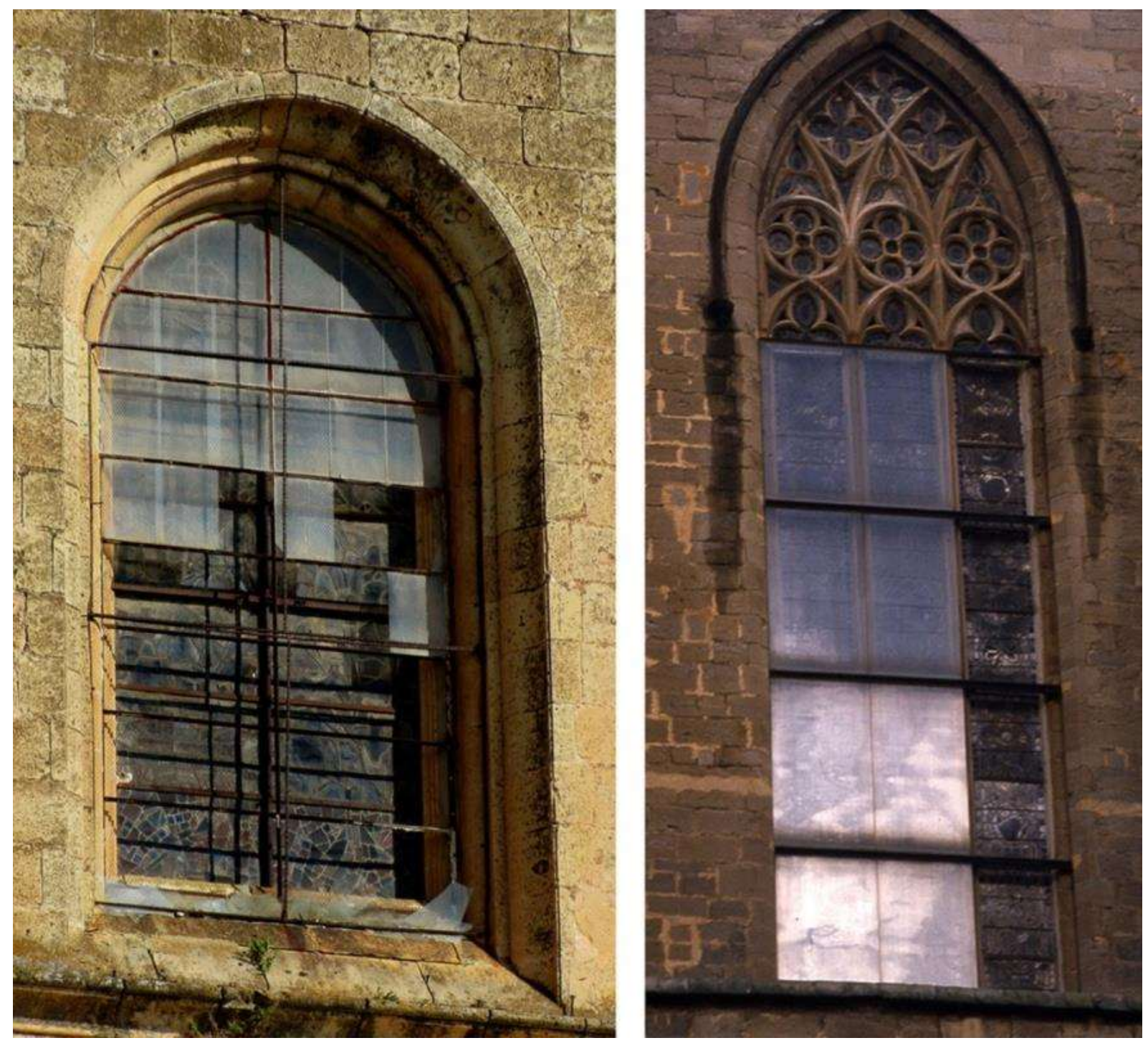

Figura 3. Roturas y pérdidas de vidrios en los acristalamientos de protección. Izquierda: Catedral de Segovia; derecha: Catedral de Manresa (Barcelona). 
En este sentido, y como nota positiva, cabe destacar la reciente redacción en 2011, por parte del IPCE (Instituto del Patrimonio Cultural de España), de un Plan Nacional de Conservación Preventiva (PNCP) (http://ipce.mcu.es/conservacion/planesnacionales/preventiva.html). En este documento se define la conservación preventiva como una "...estrategia de identificación, detección y control de los factores de deterioro de los bienes culturales, con el fin de minimizar sus efectos en los mismos. Consiste en una actuación continuada en el entorno de los bienes para evitar, en la medida de lo posible, la intervención directa sobre los mismos". El Plan Nacional de Conservación Preventiva se concibe como "... el instrumento necesario para la generalización de modelos organizativos, métodos de trabajo, criterios de actuación y protocolos o herramientas de gestión como principio fundamental para la conservación del patrimonio cultural y su mantenimiento de forma viable y sostenible en el tiempo". EI PNCP supone por tanto un cierto avance en este campo, funcionando como un libro blanco, esto es, un documento o guía con autoridad pero sin carácter de ley.

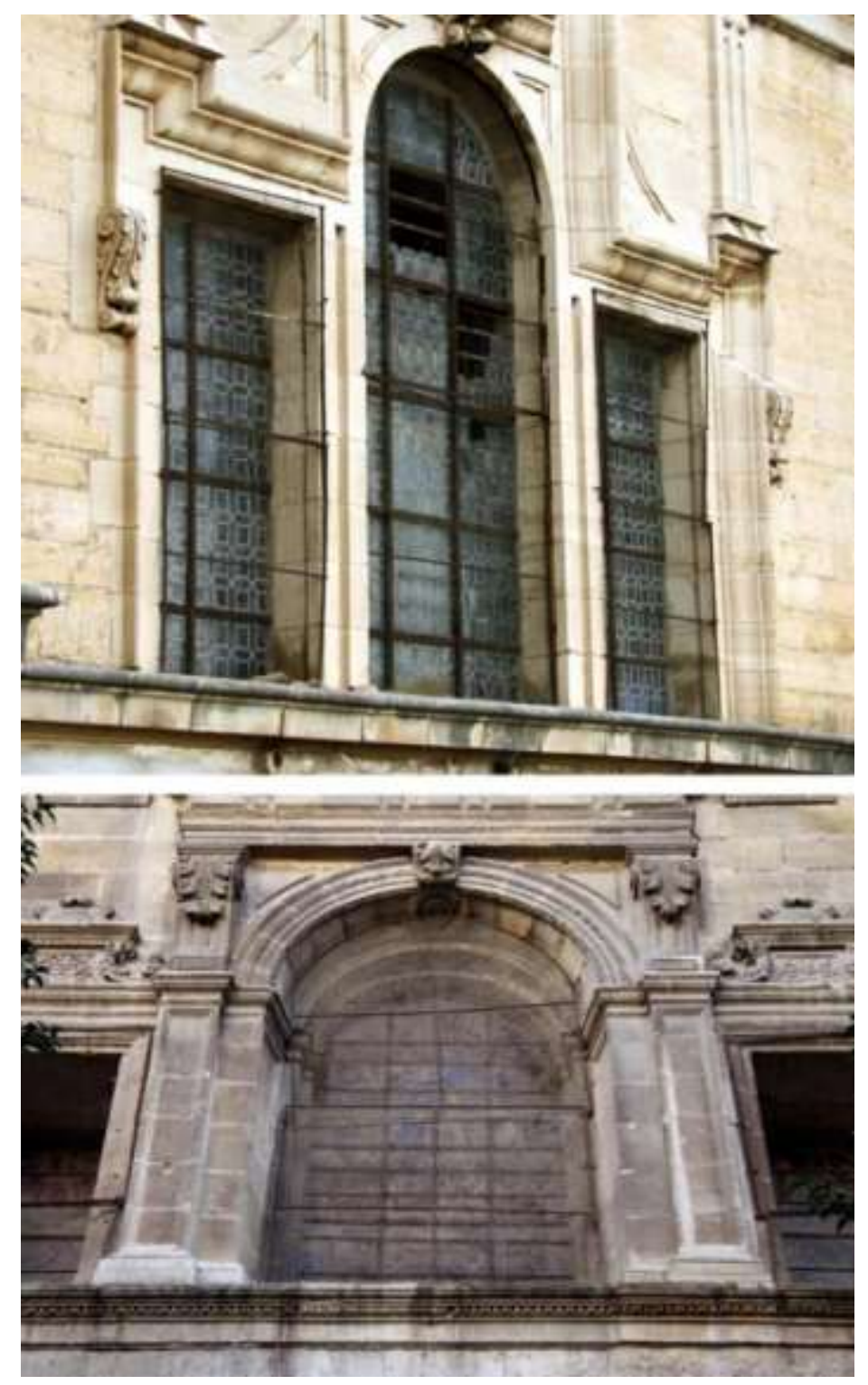

Figura 4. Deterioros en las mallas de protección de las vidrieras. Superior: catedral de Jaén; inferior: catedral de Granada. 


\section{El caso de España y las vidrieras}

Muchos edificios históricos españoles tienen un patrimonio vidriero excepcional, tanto por su cantidad como por su calidad, y sin duda se beneficiarían enormemente de la existencia de políticas de mantenimiento regular y de talleres propios. El enfoque o la filosofía de las inspecciones y el mantenimiento en el campo de las vidrieras es el mismo que para el resto del edificio. No hemos de olvidar que la primera función de las vidrieras es la de actuar como cerramiento de los edificios, garantizando su estanqueidad. En este sentido las ventanas o vidrieras son sin duda uno de los puntos más frágiles de cualquier edificio y su deterioro puede significar, no solo la pérdida de materiales históricos de gran valor, sino también el deterioro en cadena de otros bienes como consecuencia de la entrada de agua y la falta de aislamiento del exterior [figura 5].
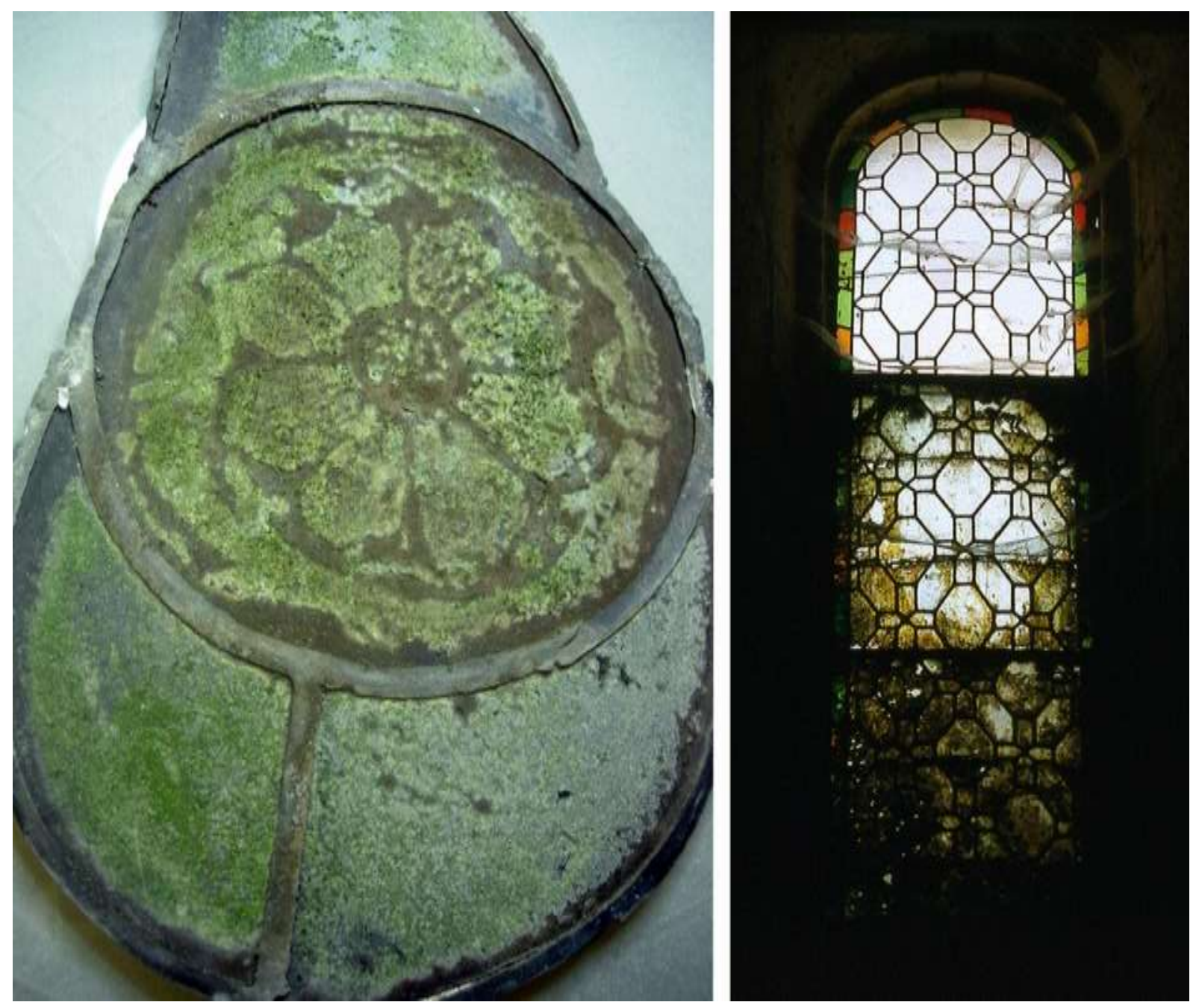

Figura 5. Diferentes daños de origen biológico relacionados con un elevado porcentaje de humedad en el interior del edificio y una deficiente ventilación. Izquierda: Cartuja de Miraflores (Burgos); derecha: monasterio de Santes Creus (Tarragona).

Esta idea no es nueva en absoluto en las vidrieras, ya que se conservan numerosos documentos que atestiguan que, desde la Edad Media, era práctica común en algunas catedrales españolas, el 
contratar a un vidriero para la realización de inspecciones periódicas y la reparación de los daños detectados. Esta sencilla actuación de conservación preventiva resultaba evidentemente más barata que las inevitables y costosas reparaciones posteriores cuando se permitía que el daño avanzara. Estas actuaciones parece que cesaron cuando el arte de la vidriera entró en declive a partir del siglo XVII y, lamentablemente, ya nunca más han vuelto a ponerse en práctica. El motivo de este abandono es, sencillamente, la escasa valoración hacia el arte de la vidriera, unida a la falta de entendimiento de sus características y funciones en la arquitectura [figura 6].
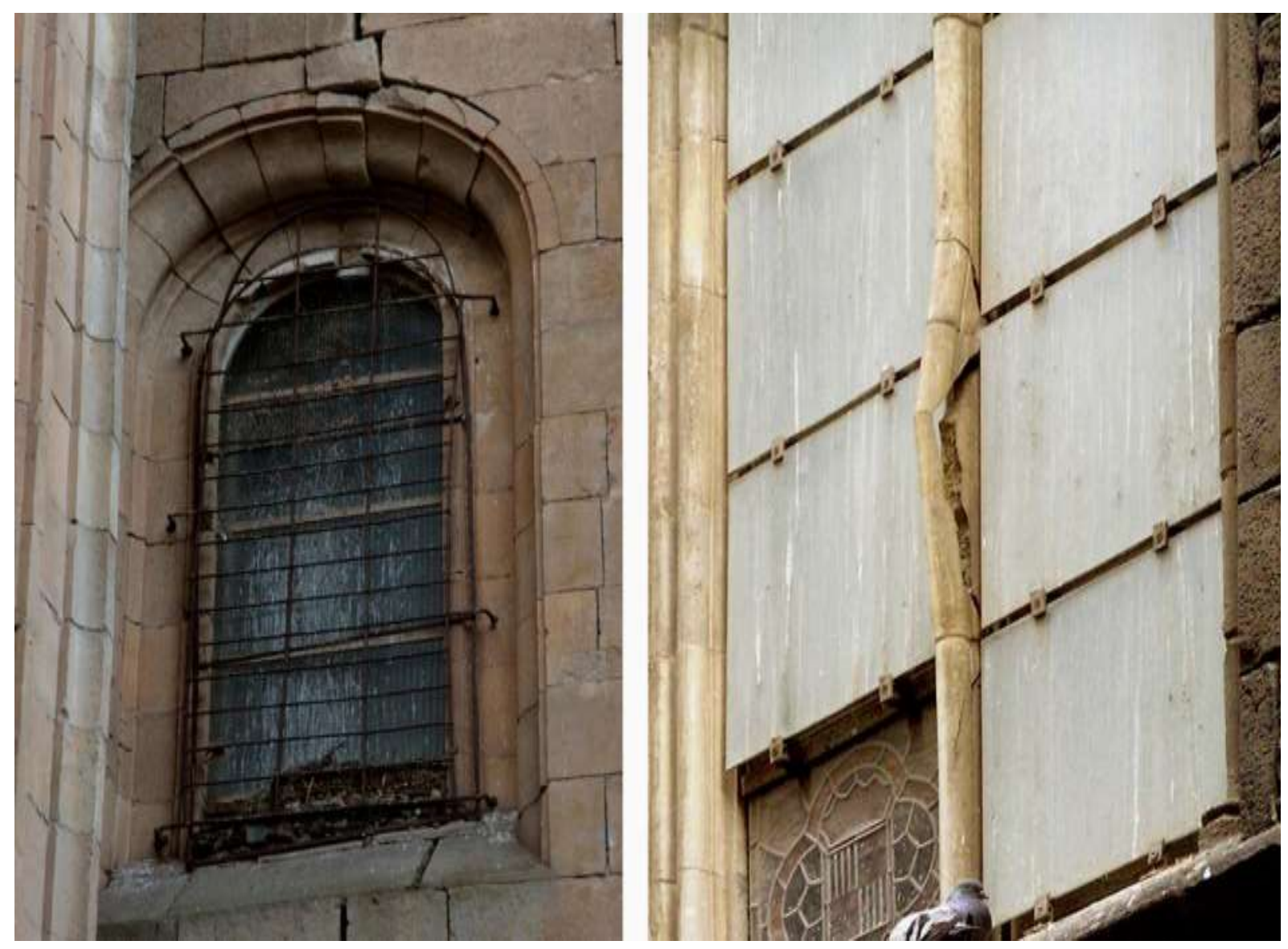

Figura 6. Problemas relacionados con los elementos pétreos de los ventanales. Izquierda: iglesia de San Esteban (Salamanca); derecha: iglesia de Santa María del Mar (Barcelona).

A modo ilustrativo de esta situación podemos mencionar el caso concreto de la catedral de Salamanca, uno de los edificios españoles más conocidos e importantes en el ámbito artístico. Entre 1543 y 1559 Nicolás de Holanda y Enrique de Broecq, dos maestros vidrieros procedentes de los Países Bajos, ejecutaron un espectacular conjunto de vidrieras, una gran parte de las cuales se encuentra desde hace ya muchos años en un estado de conservación ruinoso. Los daños que podemos apreciar en la actualidad en estas obras son el resultado de varios factores, entre los que destaca el terremoto de Lisboa de 1755. Sin embargo, el motivo principal de su estado actual es, evidentemente, la desidia y la falta general de interés por las vidrieras, ya que desde el siglo XVIII hemos tenido tiempo más que suficiente para solucionar el problema. Es lamentable que con motivo de la conmemoración del $V$ Centenario del inicio de la construcción de la catedral nueva, 
que se celebra en 2013, no se haya puesto en marcha ningún programa de actuación en las vidrieras.

Un caso similar es el que podemos encontrar en las vidrieras de la cara sur de la catedral de Segovia, si bien aquí, afortunadamente, las tareas de restauración comenzaron hace unos pocos años. El terrible abandono que han sufrido las vidrieras de estas catedrales ha originado dos de las situaciones más vergonzosas que se pueden ver en toda Europa en el campo de la conservación del patrimonio vidriero. En este sentido, la falta de una tradición vidriera en España, en comparación con la existente en otros muchos países europeos, es apreciable por ejemplo en la gran cantidad de reparaciones desafortunadas que podemos encontrar en muchos casos [figura 7].
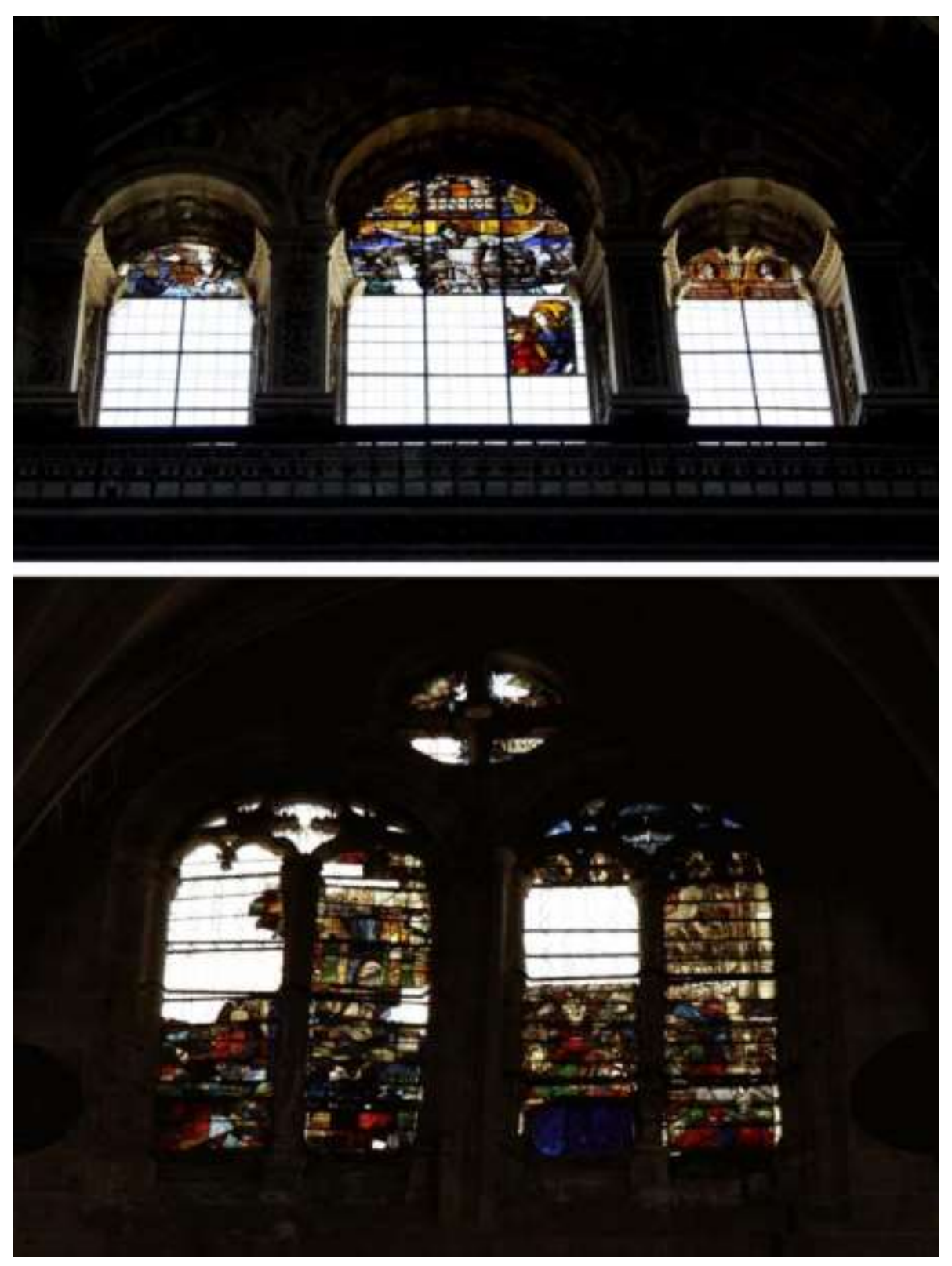

Figura 7. Pérdidas de paneles enteros en las vidrieras. Superior: monasterio de San Jerónimo (Granada); inferior: catedral de Salamanca. 
Estos edificios tan destacados son tan solo un par de ejemplos de la ausencia de una política de mantenimiento. Si bien es cierto que, en los últimos 20 años se han acometido importantes campañas de restauración en algunas de las vidrieras más antiguas de muchas de nuestras catedrales más importantes -León, Astorga, Sevilla, Ávila, Segovia o Tarragona- no es menos cierto también que en muchos casos hemos esperado demasiado tiempo para intervenir, cuando los daños surgidos eran ya demasiado graves e irrecuperables [figura 8].
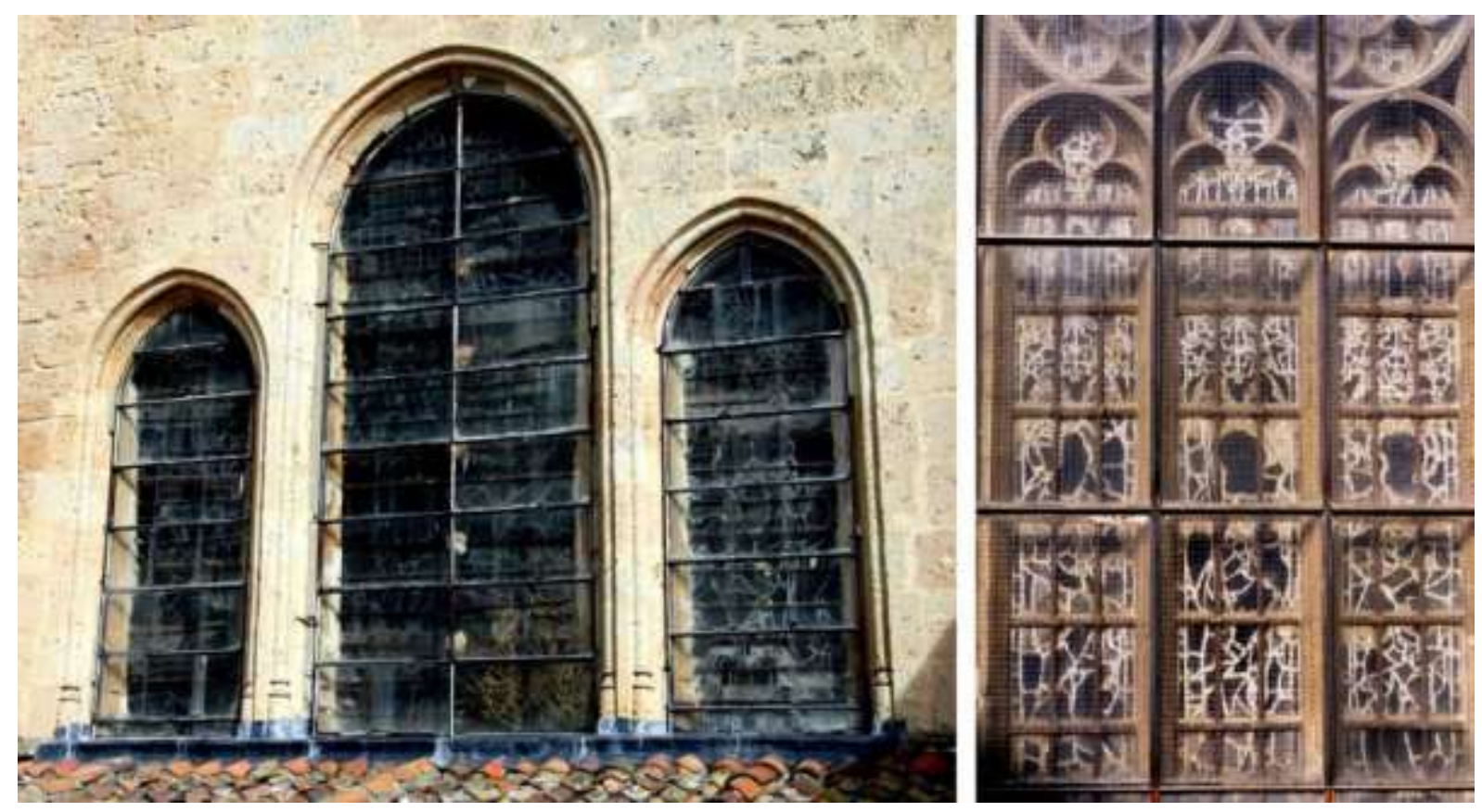

Figura 8. Crecimiento vegetativo y carbonatación de plomos como consecuencias de acristalamientos de protección sin ventilación. Izquierda: catedral de Segovia; derecha: catedral de Girona.

\section{Pautas para las tareas de inspección de vidrieras}

La situación descrita en los párrafos anteriores deriva de la falta de inspecciones periódicas de las vidrieras, a lo que hay que añadir que, la gran mayoría de los proyectos de restauración no contemplan la realización de estas inspecciones a posteriori y como una partida económica independiente. Generalmente, una vez concluida la intervención sobre la obra y desmontados los andamios, termina el trabajo de los restauradores [figura 9].

Por otra parte, el acceso a las vidrieras resulta a menudo complejo, y dado que generalmente no es viable el uso de medios de acceso como andamios o plataformas elevadoras, normalmente estas inspecciones se han de realizar desde una gran distancia y mediante el uso de prismáticos. Por tanto, la persona encargada de realizarlas ha de estar muy familiarizada con las vidrieras y ser capaz de evaluar su estado de conservación, conocer los diferentes materiales, entender su comportamiento y los mecanismos de su envejecimiento y deterioro, así como el correcto funcionamiento de los productos y sistemas de restauración. Los resultados y las conclusiones obtenidos en estas inspecciones deben ser registrados en un informe detallado. Asimismo, sería importante que cualquier posible alteración o daño detectado en las vidrieras por el personal del 
edificio se pusiera en conocimiento de los responsables de su cuidado para poder tomar las medidas oportunas [figura 10].
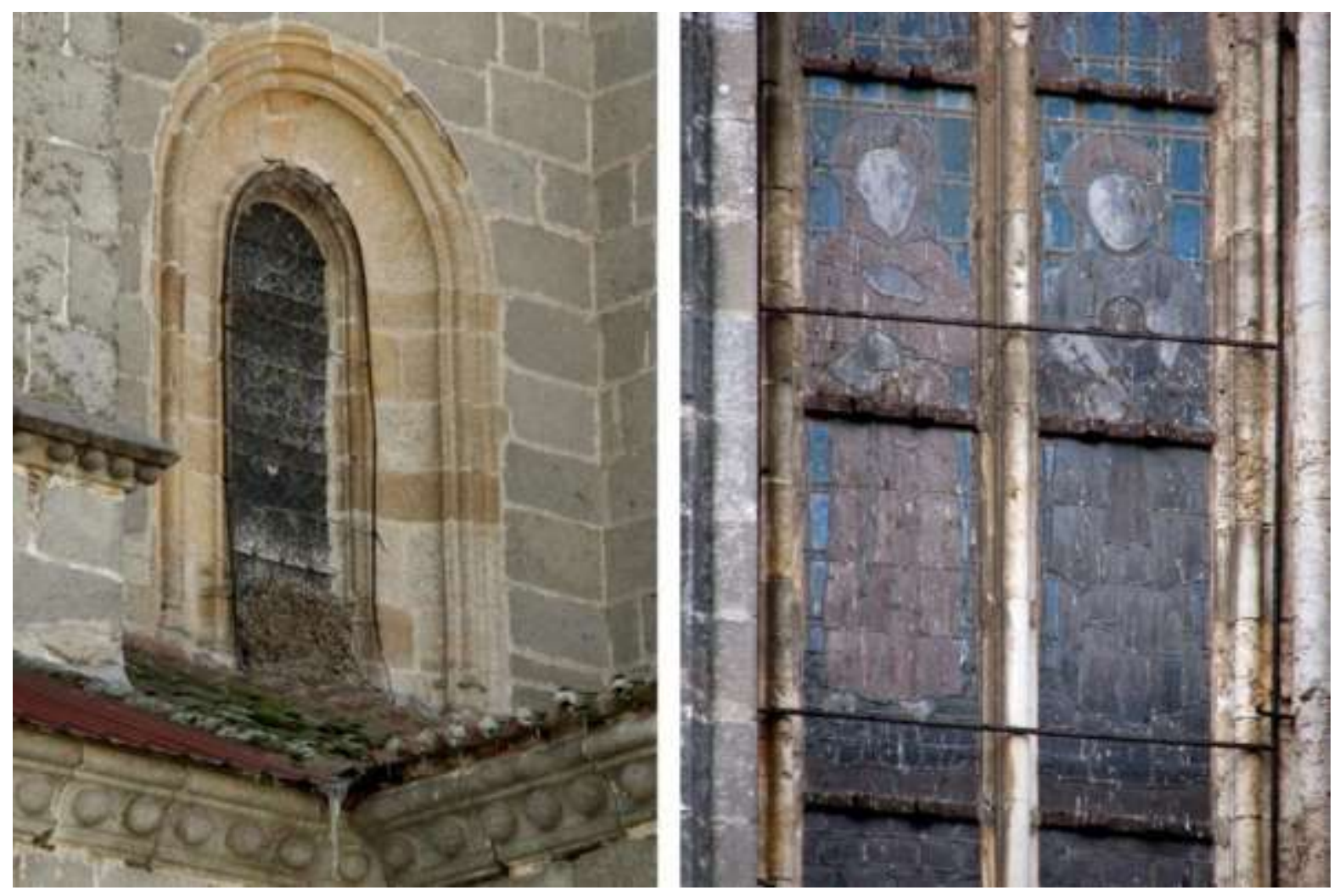

Figura 9. Formación de nidos y acumulación de excrementos de aves en las vidrieras. Izquierda: monasterio de Santo Tomás (Ávila); derecha: catedral de Girona.

Las pautas de inspección de las vidrieras son las mismas que las que se siguen para la inspección del resto de elementos vinculados al edificio. En aquellas vidrieras que hayan sido restauradas recientemente, sería importante asimismo controlar y evaluar el comportamiento de los productos de restauración y conservación utilizados, así como el correcto funcionamiento de los sistemas exteriores de protección existentes. La información obtenida durante estas inspecciones puede ayudarnos a mejorar o corregir el enfoque y la metodología a utilizar en futuras restauraciones. Estas inspecciones deberían realizarse con una periodicidad mínima anual, a menos que se detectaran problemas inesperados. Finalmente, los principales aspectos que deberían ser revisados $y$ controlados en las vidrieras y en su entorno son los siguientes:

- Presencia de fracturas o lagunas en los vidrios.

- Formación de condensaciones de agua sobre el vidrio.

- Estado de las resinas sintéticas utilizadas en el vidrio en anteriores restauraciones.

- Acumulación excesiva de depósitos de suciedad sobre la vidriera o sobre las molduras de la piedra (polvo, hollín de velas, telarañas etc.). 
- Presencia biológica sobre los vidrios (colonias de hongos, algas o líquenes).

- Presencia de excrementos o nidos de pájaros por la cara exterior de la vidriera.

- Estado de las diferentes capas pictóricas sobre el vidrio: pérdidas, levantamientos, desprendimientos, etc.

- Fracturas de plomos y estado de los puntos de soldadura de estaño.

- Presencia de carbonatación en los plomos.

- Rotura de los nudos que sujetan las varillas de refuerzo.

- Abombamientos, plegamientos o deformaciones de los paneles emplomados.

- Estado de los elementos metálicos de las vidrieras, tales como bastidores, lengüetas, pletinas, chavetas y varillas de refuerzo (fracturas, deformaciones u oxidación).

- Correcto funcionamiento de los paneles de la vidriera convertidos en ventanas practicables.

- Estado de los morteros y masillas en la vidriera y en los vidrios de protección.

- Estado y funcionamiento de los diferentes sistemas de protección instalados (mallas o acristalamientos).

- Estado de la piedra del ventanal en el que va insertada la vidriera (fracturas, desprendimientos, crecimiento vegetativo, formación de nidos, etc.).

- Estado de los paramentos, muros o tejados en las proximidades de las vidrieras (grietas, desprendimientos, presencia de humedades o colonización biológica).

- Estado de los sistemas de conducción y evacuación de aguas en las proximidades de vidriera.

- Presencia de sistemas de iluminación artificial en las cercanías de las vidrieras (posible daño estético y excesivo recalentamiento del vidrio en cortos periodos de tiempo).

- Protección temporal adecuada de las vidrieras, en el caso de que se vaya a realizar algún tipo de intervención en su entorno.

Hasta aquí se han descrito las tareas referidas a las inspecciones periódicas, las cuales no implican un contacto directo con las vidrieras, ya que están basadas en la observación y el registro de datos. En ocasiones, sin embargo, puede ser necesario realizar algún tipo de intervención directa en las mismas, la cual debería ser llevada a cabo únicamente por profesionales debidamente cualificados y capacitados. Estas actuaciones pueden incluir sencillas operaciones que no impliquen el desmontaje de las vidrieras como limpieza, extracción de algún vidrio para su reparación o sustitución, realización de soldaduras in situ, sustitución de chavetas, pletinas o varillas de refuerzo, aplicación de nuevas masillas o morteros, colocación de nuevas mallas, etc. También, a veces, puede ser necesario el desmontaje de toda la vidriera o únicamente de algún panel concreto de la misma. 

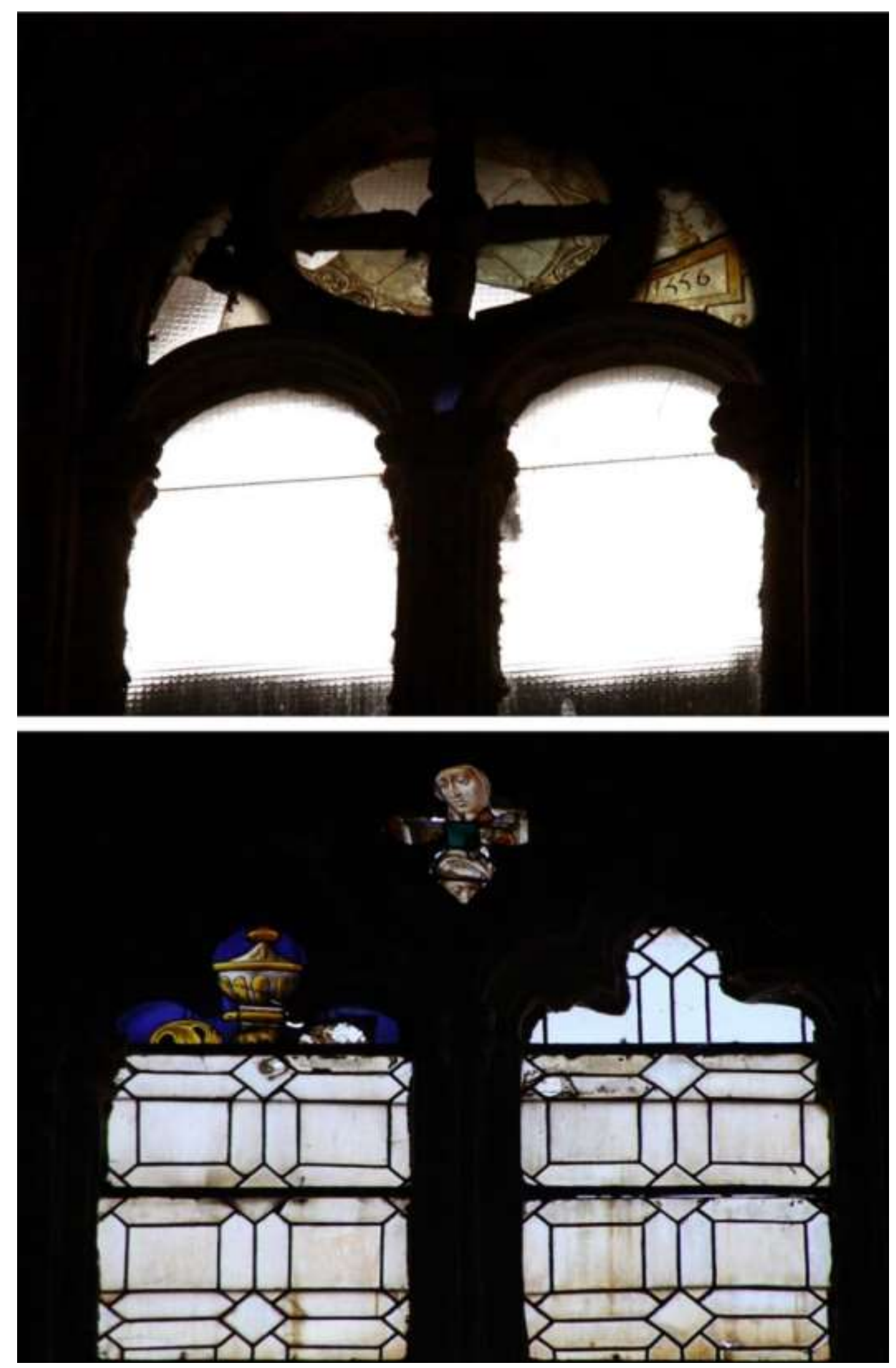

Figura 10. Restos de vidrieras del siglo XVI como consecuencia de un continuado abandono. Superior: iglesia de San Esteban (Salamanca); inferior: iglesia de San Marcos (León). 


\section{Conclusión}

La necesidad de llevar a cabo inspecciones periódicas y operaciones de conservación preventiva es de gran importancia en todos los bienes culturales y especialmente en las vidrieras. Junto a su papel estético, de transmisión de imágenes y transformación lumínica de los espacios interiores, las vidrieras son las ventanas de un edificio y funcionan ante todo como cerramiento. En edificios importantes el método más efectivo para llevar a cabo este tipo de actuaciones, como demuestran los resultados de los ya existentes en algunas catedrales europeas, sería el establecimiento de un taller propio de restauración a pie de obra. Estos talleres ofrecen a medio y largo plazo numerosas ventajas con respecto al sistema habitual de contratación externa por obra y servicio. Entre estas ventajas se destacan un mejor conocimiento del edificio y un importante ahorro económico. Sería, por tanto, deseable trasladar este sistema y forma de trabajo a los edificios españoles más significativos.

\section{Notas}

[1] Según el Diccionario de la Real Academia Española mantenimiento es el Conjunto de operaciones y cuidados necesarios para que instalaciones, edificios, industrias, etc., puedan seguir funcionando adecuadamente.

[2] La página web de la SPAB ofrece una lista detallada de las diferentes organizaciones relacionadas con la conservación de edificios existentes en el Reino Unido: http://www.spab.org.uk/contacts/other-buildingconservation-organisations/

[3] El mismo John Ruskin dijo de la catedral de Lincoln: Siempre he sostenido, y estoy dispuesto a mantener contra cualquier evidencia, que la catedral de Lincoln es sin duda la obra arquitectónica más hermosa de las islas británicas y en términos generales es más valiosa que cualquier otras dos catedrales juntas que tengamos.

\section{Bibliografía}

CASTELLANO GONZÁLEZ, I. (2007). Inspección Técnica de Edificios. Monografías de la Construcción. Ceac Técnico Construcción, Colección SC.

CROFTS, S. (2012). "Stave off decay by daily care. Peterborough Buildings". In Need Project-Summer Masterclass - Building Maintenance Sacrewell Farm, 9 June.

https://peterboroughbuildingsinneed.files.wordpress.com/2012/06/spab-maintenance-sacrewell-090612web.pdf.

NEZA CEBRON, L. y VAN BALEN, K (2008). "Preventive conservation and maintenance of architectural heritage as means of preservation of the spirit of place". En 16th ICOMOS General Assembly and International Symposium: Finding the spirit of place - between the tangible and the intangible, 29 sept - 4 oct Quebec, Canada.

W.AA.Maintenance Checklist. SPAB Faith in Maintenance.

ttp://www.spabfim.org.uk/data/files/pages/maintenance_checklist_v3.pdf.

V.AA. A Stich in Time. The Institute of Historic Building Conservation.

http://www.ihbc.org.uk/publications/stitch/stitch.html.

W.AA.Maintain our heritage. http://www.maintainourheritage.co.uk/further_reading.htm

W.AA.Maintaining traditional plain glass and glazing. INFORM. Historic Scotland. http://www.historicscotland.gov.uk/informguide-historicglass.pdf. 
V.AA. Plan Nacional de Conservación Preventiva. IPCE. Ministerio de Educación, Cultura y Deporte. http://ipce.mcu.es/conservacion/planesnacionales/preventiva.html.

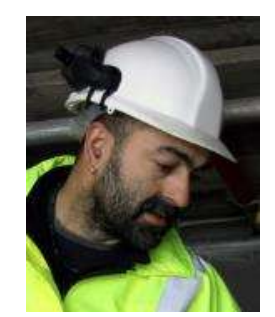

\section{Fernando Cortés Pizano}

fcpcrv@gmail.com

http://www.fcpcrv.com

Lincoln Cathedral Glazing Department

28 Eastgate, Lincoln LN2 4AA, Reino Unido

Fernando Cortes Pizano estudió la carrera de Geografía e Historia con especialidad en Historia del Arte en la Universidad Complutense de Madrid entre 1984 y 1989 y posteriormente Bellas Artes con especialidad en Conservación y Restauración de Vidrieras en la Real Academia de Bellas Artes de Amberes en Bélgica entre 1994 y 1998. Desde entonces se ha dedicado completamente al campo de la conservación y restauración de vidrieras, abarcando diferentes áreas de trabajo como intervención directa, cursos, conferencias, publicaciones, asesoramiento y direcciones técnicas. En la actualidad trabaja como restaurador de vidrieras en la Catedral de Lincoln, en el Reino Unido.

Artículo enviado el 18/01/2013

Artículo aceptado el 11/05/2013 


\title{
Comida en el arte contemporáneo. Restauración, conservación y reactivación del Eat Art
}

\author{
Lorenzo Hortal Valverde
}

Resumen: El empleo de comida en arte contemporáneo introduce en la obra un material altamente sensible a la biodegradación que imposibilita su pervivencia para el futuro, así como una fuerte intención interactiva que invita al público a participar comiéndose literalmente las piezas.

Desde el punto de vista de la restauración y conservación, el presente artículo intenta dar respuestas a los numerosos interrogantes que surgen en el profesional que se enfrenta a una obra de Eat Art. En él se realizará un repaso histórico desde la introducción del alimento en la obra hasta la actualidad. Tras sentar las bases de este movimiento, se expondrán las principales problemáticas que presenta. Se diseñarán estrategias de conservación para las mismas, prestando especial atención a la clasificación y diferenciación de las distintas tipologías existentes. Con ello se establecerán tratamientos y actuaciones adecuadas, dependientemente de la intención del artista y el respeto al significado de su obra.

Palabras clave: Arte contemporáneo, Eat Art, Comida, Performance, Arte efímero, Biodegradación.

\section{Comida em arte contemporânea. Restauro, conservação e re-activação da Eat Art}

Resumo: A utilização de comida em arte contemporânea introduz na obra um matéria altamente sensível à biodegradação que impossibilita a sua sobrevivência para o futuro, assim como encerra uma forte intenção interactiva que convida o público a participar, literalmente comendo as peças.

Desde o ponto de vista da conservação e restauro, o presente artigo tenta dar respostas às numerosas questões que surgem ao profissional que se confronta com obras de Eat Art. Vai ser feita uma retrospectiva histórica desde a introdução de comida até à actualidade. Após estabelecer as bases deste movimento serão expostas as principais problemáticas que apresenta. Para estas serão propostas estratégias de conservação, prestando especial atenção à classificação e diferenciação entre as diversas tipologias existentes. Serão estabelecidos tratamentos e actuações adequadas dependendo da intenção do artista e do respeito pelo significado da sua obra.

Palavras-chave: Arte contemporânea, Eat Art, Comida, Performance, Arte efémera, Biodegradação.

\section{Food in Contemporary Art: restoration, conservation and reactivation of the Eat Art}

Abstract: The use of food in contemporary art introduces a highly sensitive material to biodegradation, greatly complicating the future survival of the particular artwork. On the other hand, it represents a strong intention of performance, inviting the public to take part, literally eating up the pieces.

From the point of view of restoration and conservation, the given article tries to provide answers to the numerous questions arising in the professional who deals with works of Eat Art. A historical review will describe the development since food was first introduced in art. After laying the foundation of this movement, the principal challenges for restoration and conservation will be discussed. While paying special attention to the existing classifications and different typologies, strategies of conservation will be outlined in order to determine and conclude treatments and appropriate actions depending on the intention of the artist and respecting the meaning of the work of art.

Keywords: Contemporary Art, Eat Art, Food, Performance, Ephemeral art, Biodegradation. 


\section{Introducción}

[...] Todas las formas del hambre que caracterizan el amor nos guiaron en la creación de esta obra. Mediante nuestras manos, está aquí una expresión artística tan intensa como para exigir no sólo los ojos y relativa admiración, no sólo el tacto y relativas caricias, más los dientes, la lengua, el estómago, los intestinos igualmente enamorados [...].

F. Marinetti (Marinetti 1985: 18)

Con estas palabras nos introduce Marinetti en su obra «La Cocina Futurista: Una comida que evitó un suicidio». La cita forma parte de una breve historia en la que un grupo de artistas se reúnen para encontrar la manera de impedir la muerte de un compañero por la pérdida de su amada. Para ello $y$, empleando distintos alimentos, elaboran un muestrario de mujeres comestibles para deleite de su amigo, de tal manera que tras devorar los cuerpos, la satisfacción de Giulio Onesti, el posible suicida, es tal, que su vida queda a salvo de la muerte.

Inevitablemente, las conexiones de este relato con algunos artistas contemporáneos son evidentes. La creación de la obra, en muchas ocasiones, pretende alcanzar un fin determinado y, por tanto, tener una vida finita. Marinetti y sus compañeros llevan a cabo la creación de unas esculturas comestibles con la esperanza de saciar la angustia de su amigo. Podemos reparar en distintas creaciones artísticas contemporáneas similares a las del relato: en ellas podremos encontrar un trasfondo canibalista, sexual o simplemente provocador. Ejemplos como los de Leandro Erlich y su Chocolate Couch, Messestand de Sonja Alhäuser o en mayor medida las PerforMANcenas de César Martínez [figura1] nos presentan piezas que interactúan con el espectador, que le obligan a que participe para entenderlas y que no están hechas simplemente para ser contempladas sino para ser comidas.

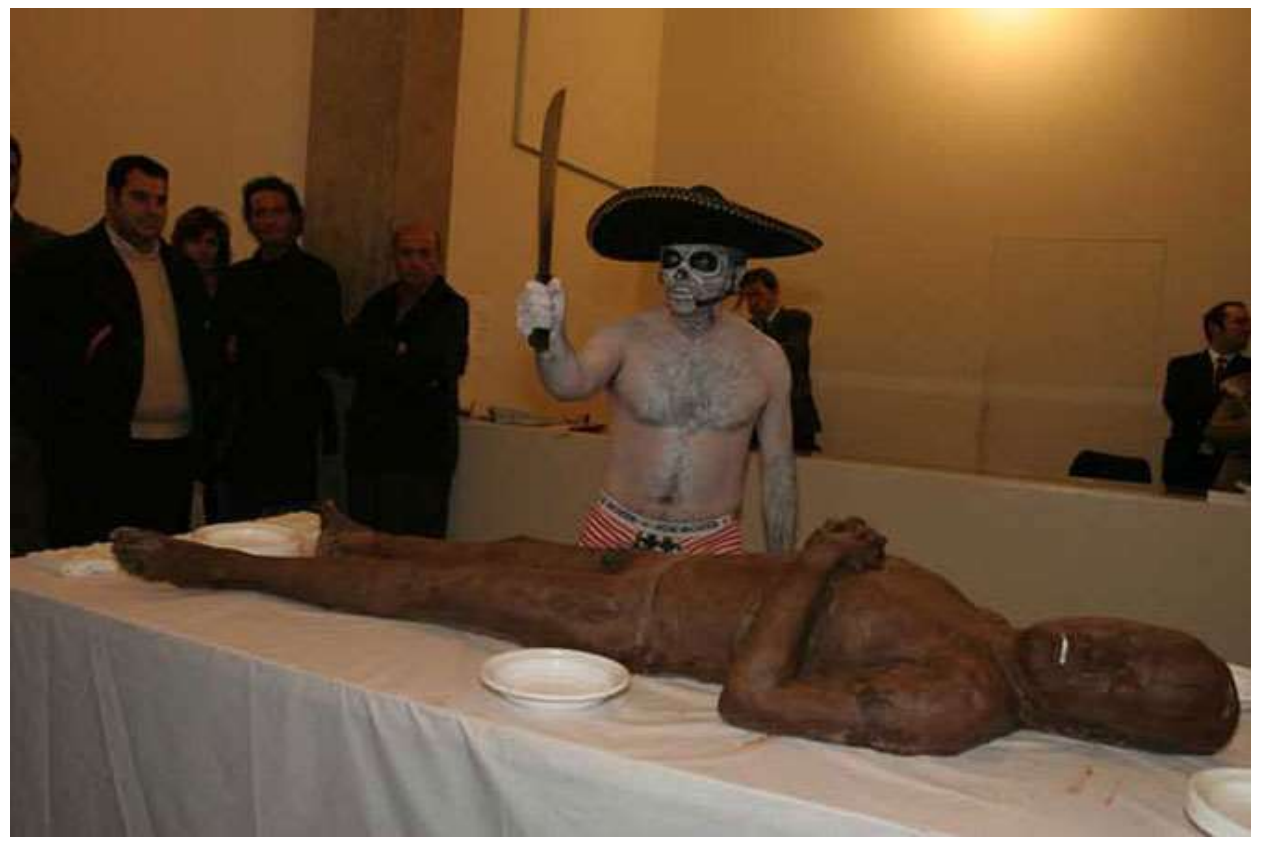

Figura 1. Neuroeconomía antropófoga, César Matinez. Centro Cultural Conde Duque. 11 de noviembre de 2004. Acto inaugural de la muestra "El imperdurable mente presente". OSofía Menéndez. 
Ahora bien, como restauradores-conservadores y, tras leer el relato de Marinetti, es imposible no reparar en el destino de las esculturas. Por un lado, la vida del compañero está a salvo, pero ¿y la de las obras? Éstas han muerto, han desaparecido y no podrán volver a ser vistas, ni comidas, por nadie. De las piezas solo quedan descripciones realizadas por el resto de compañeros, mera documentación, pero sin rastro de materia. ¿Cabe sentir lástima por su pérdida? Nuestra tarea en este momento será imaginar cuál debió ser su forma y apariencia, pero presenciarla físicamente será imposible. Esto nos lleva a una alternativa: la reactivación la obra.

Podría parecer un disparate cambiar de tiempo, de espacio y de protagonista, sin Giulio Onesti la obra nunca hubiese sido creada. Pero cabría plantearse si reactivándola se desvirtuaría su sentido, o en su lugar se recuperaría en una nueva dimensión, funcionando a modo de versión, dándole la oportunidad de volver a cumplir su función y de nuevo «evitar un suicidio».

\section{Problema de investigación}

Cabe plantearse la cuestión teórica del arte con comida de una manera sencilla y directa ¿Existe el arte con comida? La respuesta a esta pregunta puede tener un carácter evidente e incluso espontáneo, en cualquier caso la solución sería sí. Ahora bien, este estudio pretende indagar en una respuesta de mayor complejidad. Aún sabiendo que su contestación seguiría siendo sí, se pretenden clarificar los limites en los que una comida perfectamente cocinada y estéticamente presentada no puede formar parte de la disciplina arte, o por lo menos, no de la que aquí se intenta desmenuzar e investigar.

El Eat Art no tiene su origen en la gastronomía, su fin último no es alimenticio, sino artístico. Es necesario establecer las diferencias y tener claro que Antoni Miralda trabaja como un artista y Ferrán Adriá no. Mientras que Miralda formula con sus ideas piezas artísticas que se degustan no solo con el gusto, valga la redundancia, sino también con el intelecto, Adriá conforma alimentos dirigidos a la nutrición y satisfacción culinaria. Cierto es que las creaciones de Ferrán Adriá -no artísticas- también se consumen con la vista, y es posiblemente este punto el que más pueda confundir al espectador o comensal. Pero nunca debe confundirse, y siempre debe estar patente, el fin que motivó la creación de un plato del chef del momento o la producción de una obra de arte.

Al recopilar información sobre la introducción de la comida en el panorama artístico actual es fácil tropezarse con algo de caos respecto a los límites que conforman el Eat Art. Del mismo modo que no es igual hablar de alimentación que de gastronomía, no es lo mismo hablar de una obra de arte realizada con comida, que de una comida realizada de forma artística. En el presente texto se intentan distinguir los tipos de obras Eat Art para diferenciar claramente las obras de las no-obras y facilitar la tarea del restaurador conservador. El problema que intenta resolver esta investigación obliga a estudiar la comida y los distintos alimentos u objetos de cocina, y cómo estos guardan en sí, una fuerte significación que no está libre de connotaciones. Y son estas referencias intrínsecas lo que conformará un sinfín de posibilidades para los artistas. Los alimentos que forman parte de las obras no son simples pedazos de comida, frutas, carnes o trozos de bollería industrial. Tras ellas se esconden discursos trabajados previamente, que intentan comunicar algo, poseen un trasfondo o son el medio por el cual una obra puede darse por concluida. 


\section{Conservación y Restauración de Obras de Eat Art: Situación actual}

Pueden encontrarse diversidad de publicaciones en los que de forma sucinta se desarrolla la cuestión del arte con comida o Eat Art. En muchos casos se trata de ejemplos aislados que no conforman un documento potente que desarrolle en profundidad el tema. Ha sido en los últimos años cuando se han elaborado diferentes exposiciones con este tema como eje motor: catálogos como el de la exposición Eating the Universe celebrada en el museo Kunsthalle de Düseseldorf, Alemania, Comer o no Comer levada a cabo por el Centro de Arte de Salamanca (SA- LA), Eat Art: Joseph Beuys, Dieter Roth, Sonja Alhäuser de 2001 en Harvard, Eat Art (Come Arte) del Kunstmuseum de Stuttgart en 2010 o El arte del comer de la obra social Caixa Catalunya en La Pedrera de Barcelona, son exposiciones que muestran la atracción de muchos artistas por el tema de los alimentos como enlace fundamental del arte y la vida, y su gran relevancia en cuestiones tales como lo bélico, la abundancia o el hambre en el mundo. La primera exposición citada, Eating the Universe, examina los orígenes del Eat Art desde su creación por Daniel Spoerri, como temática artística, acompañada de la participación de diversos artistas que trabajan con su mismo concepto tales como Joseph Beuys, Sonja Alhäuser, Arman, Lili Fischer o Gordon Matta-Clark entre otros, unificándose de esta manera obras que inciden en un tema común.

Por otro lado, es interesante destacar la exposición Comer o no Comer, de la que como resultado fundamental, además de una interesantísima muestra compuesta por más de doscientas obras, surgió un compendio de textos, realizados por numerosos especialistas, que son posiblemente, la más completa revisión hasta la fecha, de las relaciones del arte y los alimentos en el siglo XX. Se han celebrado a su vez exposiciones que estudian el trabajo individual de determinados artistas, centrando la temática en el empleo de la comida para el discurso artístico, como en los casos de Sonja Alhäuser o Antoni Miralda.

Todos los textos de los catálogos citados anteriormente están enfocados hacia la explicación histórica e ideológica de muestras y exposiciones. La mayoría reparan en la identificación de obras y la interrelación entre unas y otras. En el catálogo de la muestra Comer o no Comer, a pesar de estar compuesto por más de quinientas páginas, no hay referencias a cuestiones de procedimientos ni materiales empleados, algo que para un especialista en la cuestión técnica, se echa verdaderamente en falta. No es sencillo encontrar estudios que reparen en las particularidades o problemáticas específicas de este tipo de piezas. Existen algunas referencias como la que Pilar Bustinduy hizo en la VI Jornada anual de Conservación de Arte Contemporáneo celebrada por el GEIIC y el MNCARS durante el año 2009, así como el congreso de conservación de escultura contemporánea que se realizó en la Tate Modern de Londres en 1995 titulado From Marble to Chocolate. En él se analizaron diferentes materiales empleados en la creación escultórica desde ejemplos realizados en piedra, madera y metales hasta algunos trabajos de arte en chocolate, analizados por Glenn Wharton, Sharon D. Blank y J. Claire Dean, en los que sí se consideran cuestiones como el deterioro del cacao, su composición química y técnicas de conservación en obras de William Mobley, Dieter Roth y Beuys, aunque solamente referidos a un único material, el chocolate.

No existen estudios que indaguen en los tratamientos a emplear en el arte con comida, tampoco una relación de obras desde el punto de vista material o físico. Cada obra es estudiada individualmente cuando la misma debe ser transportada, expuesta o tratada por un problema concreto. Es loable pero quizá insuficiente este trato individualizado y no en conjunto. Es frecuente que al centrarnos en la restauración y conservación del arte contemporáneo el hecho de establecer pautas generales o métodos únicos para actuar sobre las obras resulte complicado. Pero al hablar 
de piezas específicas dentro de una misma tipología, puede que dicha tarea sea efectiva y beneficie al Eat Art, en este caso, como conjunto. Se trata de obras con numerosas características en común que a su vez poseen diferencias muy notorias. Podemos estipular mediante su estudio pormenorizado ciertas medidas que de forma concisa ayuden a esclarecer el papel de la comida en el arte.

\section{Objetivos}

El hecho de que la comida sea el medio por el cual la obra cobra forma física, no quiere indicar en todos los casos que la obra deba ser ingerida o deba degradarse hasta la putrefacción. En muchas ocasiones la materia o comida debe permanecer inquebrantable, vigorosa al paso del tiempo. Con estas nociones de partida, el objetivo principal del estudio se centra en revisar la obra contemporánea realizada con comida, exponiendo la problemática específica de esta tipología y proponiendo actuaciones y tratamientos determinados. Creando con ello un documento interesante y útil desde el punto de vista de la restauración y conservación.

El discurso y eje vertebrador del estudio se basa en analizar la presencia de comida en la obra, no sólo en los casos en que dicha comida se muestra incluida en una performance u obra participativa. La investigación indaga en las cuestiones específicas de tres tipos de obras: ya sean con intención de durabilidad, de arte efímero o de piezas interactivas. Se repasa su historia así como el momento de su incorporación en el panorama artístico. A su vez se muestra, a lo largo del análisis, cómo estas obras deben ser entendidas y cuál debe ser la actitud del restauradorconservador ante unas determinadas características. Con esa información se han diseñado diferentes estrategias, formuladas para abordar cada una de las diferentes obras examinadas. El resultado se verá recogido en una tabla resumen, donde se mostrarán, de forma clara, las diversas opciones y soluciones aplicables. Contando siempre con la intención artística que la propia pieza presente.

\section{Metodología}

La investigación se dividió en cuatro partes fundamentales, que aunque separadas y diferenciadas, poseen una estructura fundamental que unifica el estudio, dándole una forma única y continuada. La metodología empleada partía de un plano general, abordando la comida en el arte de forma global y, poco a poco focalizando la atención en la creación contemporánea. Se analizó la problemática que estas piezas presentan y por último se aportaron soluciones y estrategias de conservación. A continuación se muestran, de forma reducida, los distintos capítulos de la investigación y sus correspondientes conclusiones:

\section{Resultados del trabajo:}

\section{Parte I. Relación entre arte y comida: revisión histórica}

La comida ha constituido una fuente de inspiración para los artistas, quienes según la época la han interpretado desde perspectivas muy distintas, dando como resultado obras categóricamente opuestas. Todos los atractivos que los alimentos tuvieron para los antiguos creadores siguen vigentes en las vanguardias y llega hasta el arte más actual de la mano de artistas que otorgan a estos materiales dimensiones nuevas y dispares que alientan nuevos relatos. 
Desde la pintura meramente ilustrativa o documental que nos muestra maneras de cocinar, platos típicos y banquetes referentes de épocas como la egipcia o la romana se ha realizado un viaje por la representación del alimento en las distintas religiones. La comida cobra sentido específico, convirtiéndose en símbolo, aunque siempre de manera anexa o complementaria en la obra y su composición [figura2]. Ya en los siglos XVI y XVII la llegada del bodegón haría que ésta saltara a un primer plano y se convirtiera en la protagonista de la escena. Pero dependiendo de la época de la obra, la comida se ha introducido con diversas intenciones, ya fuera como indicativo de una posición social en Vermeer o Van Gogh, como elemento caricaturesco de sátira o ironía en los geniales retratos de Arcimboldo o a modo de única protagonista de la composición ya en bodegones llenos de detalle como los de Luis Meléndez o Paul de Vos. Dicha tipología será rescatada constantemente por los artistas para abrir nuevos discursos, no deteniéndose sólo en el apartado estético, pudiendo además hacer referencias a temáticas religiosas, antropológicas, filosóficas o críticas para con la política del momento. Cada creador imprime en el bodegón su mirada única. Mientras que Chardin congelaba el instante en sus nítidas captaciones del momento, Cézanne, precursor de las formas abstractas, concedía un especial protagonismo a los elementos. Todo objeto sobre su mesa -jarra, taza o manzana- era tan significativo como cualquier figura dibujada en un «cuento» ilustrado (Charlesp 2011:42). Picasso presentará otra evolución en los objetos y alimentos de estas naturalezas muertas, en los diversos bodegones que realizó entre 1906 y 1908, mostrando la elocuencia vertiginosa de un nuevo lenguaje (Charlesp 2011:50). Gauguin, Matisse, Salvador Dalí, Juan Gris o Luis Fernández se servirán también de la potencia expresiva de la comida y sus elementos para plasmar sus imaginarios en el soporte artístico.

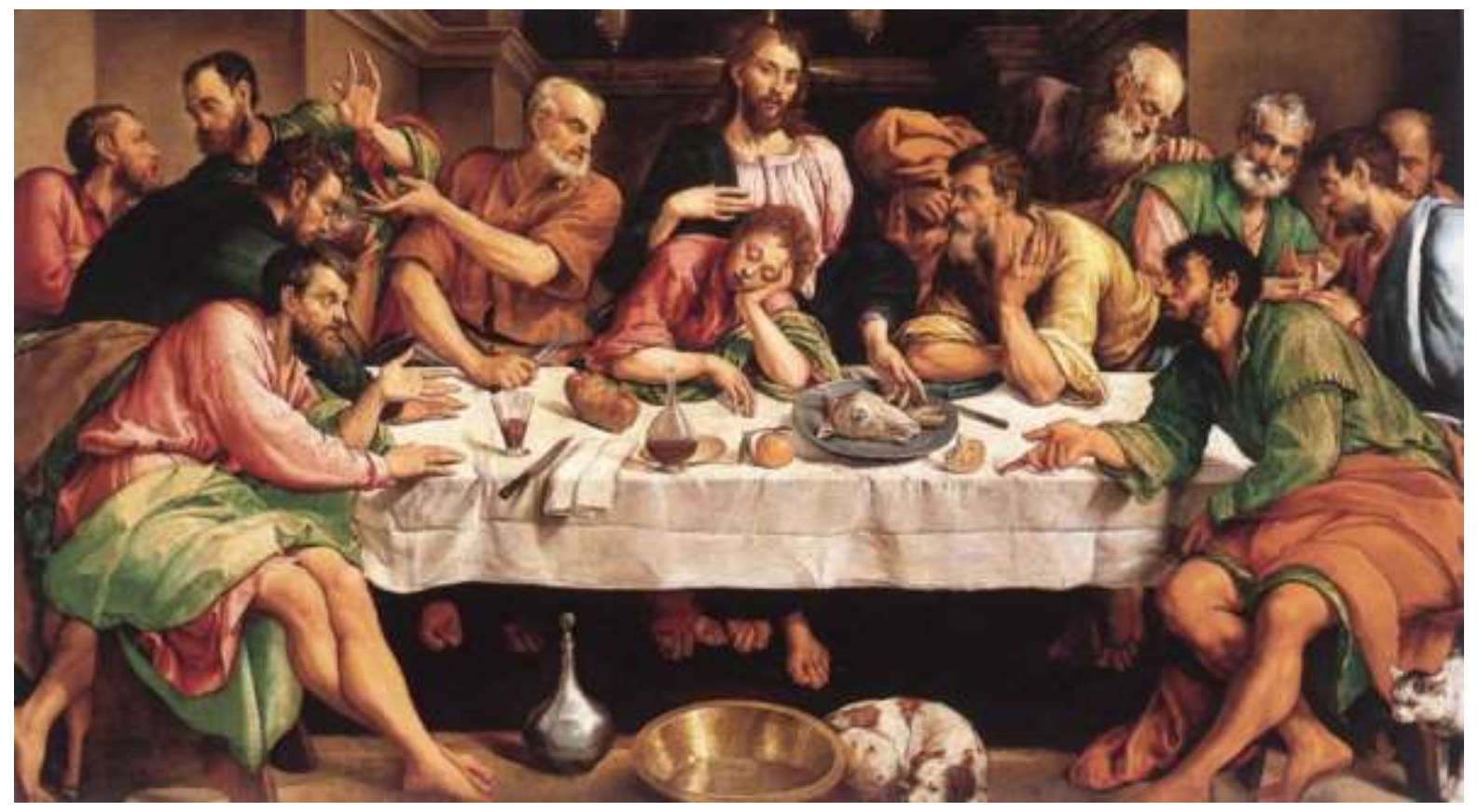

Figura 2. La última cena, Jacobo Bassano. c. 1546, Galleria Borghese, Rome.

Tras las creaciones de estos artistas modernos que aún están sujetas a una tradición de marcada inmovilidad, los artistas contemporáneos suponen un giro completo a la temática. El bodegón da paso a la representación de la comida como vehículo idóneo para los temas más dispares, enseñando al observador nuevas formas de mirar y de entender los objetos de cocina y los 
alimentos seleccionados. Josef Sudek, Mona Hatoum, Miralda, J. Sterbak o Macerl Broodthaers son claros ejemplos de ello. Con sus creaciones todo cobra una nueva dimensión, nuevos factores entran ahora a formar parte de la obra: el tiempo, la luz, el olor, el sabor o el propio espectador son parte de sus discursos artísticos.

\section{Parte II. Presencia de comida en arte contemporáneo}

La imposibilidad de lo real en la obra de arte dejó de ser una utopía, y con ella diferentes movimientos artísticos introdujeron objetos y enseres de lo cotidiano en el plano de la creación. El conceptualismo, líneas artísticas como el dadaísmo, Fluxus y muchas otras, hicieron posible la presencia real de la materia del día a día. Es en este punto cuando la comida, de la mano de Daniel Spoerri, se eleva como parte íntegra de la pieza y se presenta directa, sin engaños ni falsedades. Mientras que Willem Heda pintor holandés del siglo XVII ilustra en sus minuciosos óleos mesas ya usadas, repletas de restos de comida, trozos de pan y mondas de fruta, cubiertos y vajillas sucias acompañadas de bebidas medio vacías, Spoerri, en un discurso muy parecido, muestra una obra prácticamente idéntica, con la salvedad de que los platos son verdaderos platos, así como vasos, colillas y jarras, pan, carnes y frutas son mostradas tal como son. La obra se funde con la realidad, es real. Los materiales, débiles y de fuerte carácter perecedero ( $y$ dispuestos en contra de la gravedad por la posición vertical en que Spoerri los coloca) luchan por la supervivencia en un contexto y en una eternidad contra natura.

Esta segunda parte estudia las manifestaciones artísticas contemporáneas donde existe el empleo de alimentos como materia principal. Inspirándose en la tradición, estos creadores llegan mucho más lejos incorporando directamente la comida en sus piezas. Se muestran las obras que son referencia clave para la investigación, diferenciando de forma clara cuales son verdaderas obras de Eat Art y cuales poseen referencias directas a alimentos pero no existe presencia alguna de los mismos y, por tanto, se encuentran fuera del objetivo del presente estudio.

Se pudo formular por tanto en este apartado una diferencia clara: por un lado podemos encontrar artistas que trasladan la cocina o el restaurante a las salas de exposiciones, donde cobran una nueva dimensión, espacios que se trasforman y no sólo esperan ser vistos y recorridos, también ser olidos y comidos. En ellos se deja que el espectador toque y llegue a comerse las obras que aparentemente sólo están para ser miradas. Otros artistas crean verdaderos restaurantes sirviendo menús determinados a los asistentes, jugando con las formas, los colores o los títulos de los platos mostrados, creando un ambiente y un discurso que ayuda a la comprensión e introducen en la performance, en el universo único del confabulador del espectáculo. La comida se comporta como el medio por el cual la idea o el mensaje del artista llega al público [figura 3].

Otras creaciones no permiten la destrucción de la obra por parte del observador; ésta funciona como una verdadera escultura, un volumen tridimensional que puede recorrerse espacialmente y con la mirada, la comida presente le da significado pero no está para comerse. Dentro de estas piezas realizadas con comida para ser mirada, algunos artistas llegan más lejos indagando en su carácter efímero, mostrando a los espectadores estados avanzados de descomposición y lo que éstos pueden causar en otros materiales o en nuestra propia percepción. Existen además obras que aun mostrando comida, lo hacen de forma poco directa, ya sea mediante vídeos o fotografías, aquí la obra precisa de materiales orgánicos como los alimentos para dar sentido a su discurso, pero el material fue usado por el artista en solitario y es mostrado posteriormente en forma de documento. La obra ha perdido por tanto la parte orgánica, su resultado es un material alejado de la comida, su soporte es diferente a los anteriores, pero pertenece al catálogo general del Eat Art. 
Este estudio desembocó en el diseño de una tabla que agrupa las distintas tipologías, con las que poder seguir avanzando en el proyecto de forma clara y concisa: [tabla 1]

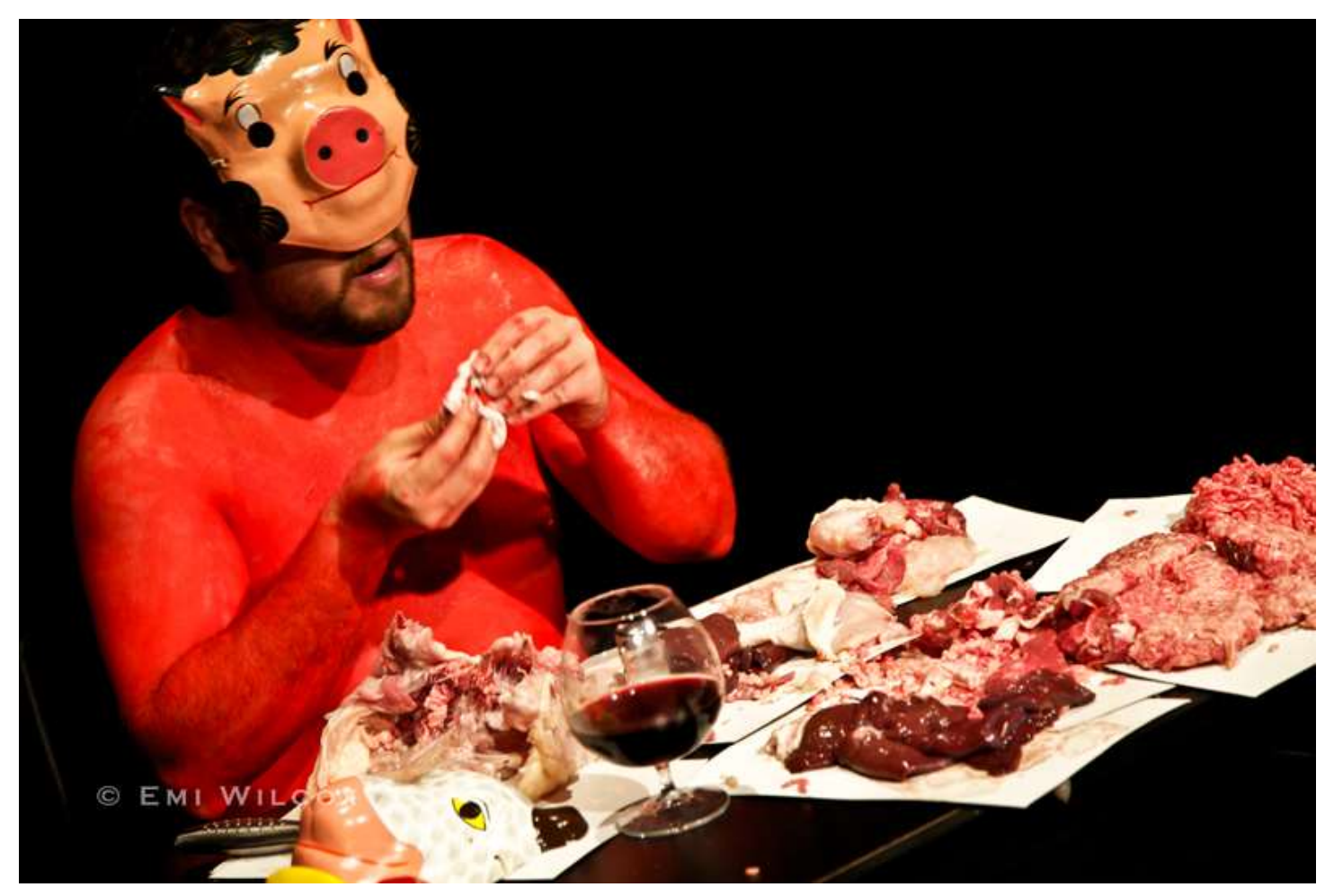

Figura 3. Banquete Atropoozoomórfico, Emi Wilcox. Performance. ( )ل Pérez Buitrago.

Tabla 1 de Tipologías de obras Eat Art/estrategias para su conservación y restauración.

\begin{tabular}{|l|l|l|l|l|}
\hline \multicolumn{2}{|c|}{ Obras CON presencia física de comida } & \multicolumn{2}{c|}{ Obras SIN presencia física de comida } \\
\hline $\begin{array}{l}\text { Obras de carácter } \\
\text { duradero }\end{array}$ & $\begin{array}{c}\text { obras de carácter } \\
\text { perecedero }\end{array}$ & $\begin{array}{l}\text { Obras que implican } \\
\text { una acción artística }\end{array}$ & \multicolumn{1}{c|}{ Fotografía } & Video arte \\
\hline $\begin{array}{l}\text { La obra está ideada } \\
\text { para que sus } \\
\text { materiales no } \\
\text { perezcan y se } \\
\text { conserven en el } \\
\text { estado en que } \\
\text { originalmente fueron } \\
\text { dispuestos por el } \\
\text { artista. }\end{array}$ & $\begin{array}{l}\text { La obra está ideada } \\
\text { para que sus } \\
\text { materiales } \\
\text { permanezcan } \\
\text { inmutables. La } \\
\text { intención del artista } \\
\text { radica en mostrar el } \\
\text { proceso de deterioro } \\
\text { natural y el resultado } \\
\text { de la degradación } \\
\text { producida. }\end{array}$ & $\begin{array}{l}\text { La obra está ideada } \\
\text { para que el } \\
\text { espectador } \\
\text { interáctue con la } \\
\text { misma de una forma } \\
\text { concreta, } \\
\text { previamente, ideada } \\
\text { por el artista, en } \\
\text { muchas ocasiones } \\
\text { acompañado de } \\
\text { actos o rituales } \\
\text { marcados. }\end{array}$ & $\begin{array}{l}\text { La obra fotográfica } \\
\text { presenta imágenes } \\
\text { que para su discurso } \\
\text { artístico precisan de } \\
\text { la aparición de } \\
\text { comida, ya sea en } \\
\text { condiciones } \\
\text { naturales o } \\
\text { manipulada } \\
\text { previamente }\end{array}$ & $\begin{array}{l}\text { La obra de vara su discurso } \\
\text { quístico precisan de } \\
\text { la aparición de } \\
\text { comida, ya sea en } \\
\text { condiciones } \\
\text { naturales o } \\
\text { manipulada } \\
\text { previamente. }\end{array}$ \\
\hline
\end{tabular}




\section{Parte III. Problemática específica del Eat Art}

Estudiado lo que significa una obra de Eat Art, habiendo dejado claras las claves para su comprensión, lectura y los tipos de obras que pueden encontrarse, se realizó un esquema conciso donde quedaban expuestas en forma de grupos diferenciados. Teniendo conocimiento de las clases y su carácter específico se analizaron las problemáticas derivadas de cada grupo, dependiendo de si el deterioro es realmente un daño directo hacia la obra o se trata de un proceso degenerativo buscado por el artista, se evaluaron las posibles causas y los inconvenientes de su presencia en la obra. De igual forma se planteó la cuestión de la idea o concepto frente a la materia constituyente. Esta fase se centró en las piezas en las que existía presencia física de comida, dejando los soportes celulósicos y el video arte fuera del estudio.

Obras con carácter duradero, perecedero o de carácter participativo no suponen, en ningún caso, el mismo conflicto para el conservador-restaurador. En el caso de obras con intención de durabilidad en el tiempo se presenta una problemática derivada de su constitución, en segundo lugar de su incomprensión o falta de información y en tercer lugar a causa de sus condiciones expositivas. En piezas que implican una acción artística (performance art) el problema puede proceder por un lado de su propia naturaleza y por otro, al igual que en el anterior caso, por incomprensión o falta de información. Por último, en obras de carácter perecedero sus problemas derivarán de su degradación -en cuanto que afecten al resto de la colección o piezas expuestas cerca-, de sus condiciones expositivas y su incomprensión algo común en los tres tipos que puede causar la tergiversación del discurso y de sus formas. Tras analizar las patologías frecuentes de numerosas obras se concluyó que cada tipo coincidía en una serie de funciones o finalidades más o menos similares, por lo que la tabla iniciada en el segundo capítulo se completó con estas especificidades que provocan unas problemáticas u otras en la pieza, lo que determinará la estrategia a diseñar para su preservación.

\section{Parte IV. Estrategias en conservación-restauración de obras Eat Art}

Finalmente el estudio se enfocó en desarrollar estrategias específicas para el tratamiento de obras de Eat Art, refiriéndose en todo momento al sistema de división formulado anteriormente. Se establecen tratamientos o formulas singulares para cada tipología, dejando claras las pautas a seguir y la actitud que debería tomarse a la hora de enfrentarnos a una pieza con unas determinadas características.

La presente investigación indaga en cuestiones referidas a la materia, la parte física de la obra: la comida. En el arte contemporáneo, lo material es sólo una de las muchas caras que nos presenta el artista. El contenido así como el significado y su mensaje son valores que en la mayoría de la ocasiones cobran más relevancia que el propio cuerpo de la pieza. Al estudiar una obra concreta, puede verse cómo no existe una marcada separación entre concepto y materia. Ambas propiedades van parejas, son inseparables. Si un especialista subsana el daño en una tableta de chocolate, sustituye una barra de pan o hace una réplica de un caramelo, inevitablemente tanto la parte física como la conceptual estarán siendo modificadas, ya sea permitiendo la sustitución y variación de los materiales o por el contrario respetando su inalterabilidad y mantenimiento de los originales. Ahora bien, esto podrá ser una acción permitida por el artista y encajar perfectamente con la intención de la pieza, pero en otros casos puede que se trate de una acción injustificable que trastoque la esencia de la obra. Por ello debe tenerse mucha precaución con la estrategia o el tratamiento seleccionado, concediéndosele la importancia justa a cada parte. Se evitará de este modo, caer en errores a la hora de conservar partes u objetos superfluos, otorgándoles más 
importancia de la que verdaderamente reclaman. Este estudio pretende facilitar esa labor, mostrando estrategias a emplear desde la intención del propio autor. Un ejemplo sería la conservación del material, o materia constituyente, procurando su perdurabilidad ante el paso del tiempo. Pero también podremos enfrentarnos a la conservación de la idea o intención original, permitiendo que la obra se deteriore y termine destruyéndose, no atendiendo por ende a su parte física.

Cada una de las distintas acciones que podrán llevarse a cabo estarán determinadas por el carácter específico de la obra. Debido a todo ello, existen situaciones donde la decisión a tomar puede presentar un conflicto debido a intereses secundarios: ya sea por parte de una institución, el propio artista, el museo o el dueño. El trabajo del conservador se centrará por tanto, en dar las soluciones más adecuadas para mantener la intencionalidad artística, nunca el interés de un tercero. Si se trata de una obra efímera, dicha pieza deberá perecer, de igual modo una obra con una posición concreta en el espacio o que necesita de una interacción del público no deberá modificarse. Si esto sucediera estaríamos ante una mala opción de conservación, desvirtuando el concepto que el autor imprimió en la misma.

Al adoptar un criterio para el tratamiento de una obra, éste deberá responder entre otras problemáticas a sus cuestiones legales. Es necesario tener total conocimiento de la situación de la pieza, respetar los derechos morales del autor, y saber por un lado si el mismo está vivo, y por otro, quién es su dueño actual. Existe una normativa que debería responder a las problemáticas que se plantean durante el tratamiento del arte más actual, pero lamentablemente encontramos líneas que deberían revisarse ya que son confusas y contradictorias con gran parte del catálogo contemporáneo. Son necesarias nuevas definiciones legales que ayuden en la aplicación de la normativa sobre obras de difícil interpretación, así como un estudio de los derechos que se adquieren con una obra y los que sigue manteniendo el creador. Ambas revisiones evitarían posibles enfrentamientos surgidos durante la restauración-conservación. Una mejora en la Ley de Propiedad Intelectual flexibilizaría la adaptación y correcto empleo de la misma. Creaciones artísticas como las revisadas, que poseen un carácter finito y deben destruirse con el tiempo o por la interacción del espectador, no siempre están bien contempladas en las normativas vigentes, las cuales instan a la conservación de la obra física por encima de otros factores.

Con todas estas consideraciones, el resultado primordial del estudio se centra en instaurar y poner a disposición del lector una metodología precisa para facilitar la comprensión del Eat Art y permitir el abordaje desde el punto de vista de la conservación. Para ello, se ha tenido en cuenta algo que desempeña un papel destacado en todo proceso de restauración: el poseer un conocimiento preciso para conseguir aplicar un procedimiento acertado que ayude a la preservación de la pieza y no entorpezca la correcta lectura de la misma. Se evitará con ello la pérdida total de ésta o su mala interpretación, lo que daría como resultado en cualquier caso, su mutilación [tabla 2].

Analicemos a modo de ejemplo alguna obra de Eat Art, para de este modo aplicar el recorrido indicado en la tabla hasta dar con una posible estrategia a seguir. Observemos una obra de Thomas Rentmeister, artista que ha trabajado en numerosas ocasiones con alimentos para dar salida a su interior reflexivo de una forma tridimensional sencilla y efectiva. En una de sus obras, Rentmeister altera notablemente los significados de un retrete común y una simple crema de chocolate para untar, el resultado es Mr. Clever. En la sala podremos observar un urinario lleno hasta arriba de la crema con un oscuro aspecto. Poniendo en evidencia la fuerza visual de la Nutella sacada de su contexto habitual, la alteración es evidente e invita a la reflexión de los significados prefijados que nos rodean. 
Tabla 2 de Tipologías de obras Eat Art/estrategias para su conservación y restauración.

TIPOLOGÍAS DE OBRAS DE EAT ART / ESTRATEGIAS PARA SU CONSERVACIÓN y RESTAURACIÓN

\begin{tabular}{|c|c|c|c|}
\hline & Carácter & Función y finalidad & $\begin{array}{l}\text { Estrategias de conservación } \\
\text { restauración }\end{array}$ \\
\hline \multirow[t]{2}{*}{$\begin{array}{l}\text { Obras de } \\
\text { carácter } \\
\text { duradero }\end{array}$} & \multirow{2}{*}{$\begin{array}{l}\text { La obra está ideada para } \\
\text { que sus materiales no } \\
\text { perezcan y se conserven } \\
\text { en el estado en que } \\
\text { originalmente fueron } \\
\text { dispuestos por el artista. }\end{array}$} & $\begin{array}{l}\text {-Función estética o visual. } \\
\text {-Función operativa. }\end{array}$ & -Reposición \\
\hline & & -Función estética o visual. & $\begin{array}{l}\text {-Reposición } \\
\text {-Sustitución } \\
\text {-Recreación }\end{array}$ \\
\hline \multirow[t]{2}{*}{$\begin{array}{l}\text { Obras de } \\
\text { carácter } \\
\text { perecedero }\end{array}$} & \multirow{2}{*}{$\begin{array}{l}\text { La obra está ideada para } \\
\text { que sus materiales } \\
\text { permanezcan } \\
\text { inmutables. La intención } \\
\text { del artista radica en } \\
\text { mostrar el proceso de } \\
\text { deterioro natural y el } \\
\text { resultado de la } \\
\text { degradación producida. }\end{array}$} & $\begin{array}{l}\text {-Descomposición tras la } \\
\text { degradación máxima -pérdida } \\
\text { de la pieza- }\end{array}$ & -Reactivación \\
\hline & & $\begin{array}{l}\text {-Mantenimiento del desecho } \\
\text { como resultado final. }\end{array}$ & $\begin{array}{l}\text {-Plastinación } \\
\text {-Momificación } \\
\text {-Disecación }\end{array}$ \\
\hline \multirow{2}{*}{$\begin{array}{l}\text { Obras que } \\
\text { implican una } \\
\text { acción } \\
\text { artística } \\
\text { performance }\end{array}$} & \multirow{2}{*}{$\begin{array}{l}\text { La obra está ideada para } \\
\text { que el espectador } \\
\text { interáctue con la misma } \\
\text { de una forma concreta, } \\
\text { previamente, ideada por } \\
\text { el artista, en muchas } \\
\text { ocasiones acompañado } \\
\text { de actos o rituales } \\
\text { marcados. }\end{array}$} & $\begin{array}{l}\text { - Acción en que el artista es el } \\
\text { único que entra en contacto } \\
\text { con la comida. Mientras es } \\
\text { observado por el espectador. }\end{array}$ & -Recreación \\
\hline & & $\begin{array}{l}\text {-Acción en que el público entra } \\
\text { en contacto con la comida. }\end{array}$ & -Reactivación \\
\hline
\end{tabular}

El problema más evidente que surge al rato de analizar la pieza no radica en la conservación del sanitario, el cual presenta una fácil preservación y las alteraciones que se le pueden plantear son pocas y los tratamientos no variarán mucho de la retirada de polvo y protección, buen almacenamiento y correcto embalaje para transporte. Fijando la atención ahora en el contenido, la crema de cacao, sí surgen interrogantes. En primer lugar el artista está vivo y previsiblemente no resultará difícil ponerse en contacto con él, o hacerlo la institución interesada en adquirir la pieza en cuestión. Las medidas que deberán tomarse con ella podrán ser analizadas junto a su creador, pero ya que se trata de una hipotética estrategia, debatamos diferentes opciones.

En primer lugar surge el interrogante del mantenimiento de la obra en sala, tareas normales de limpieza de depósitos superficiales o revisar que todo esté en correcto estado se vuelven mucho más complicados al tratarse de una superficie «pegajosa» altamente atrayente para gran cantidad de partículas de suciedad. Dadas las características de la Nutella, toda mota de polvo o partícula sólida será muy probable que termine incrustada en la crema dulce, al igual que cualquier acto «vandálico» o accidental que pueda provocar el visitante, como tirar cualquier papel o pequeño 
objeto dentro del chocolate o incluso tocar el alimento. Estas alteraciones, que en cualquier obra se solucionarían pasando un paño de microfibra, un plumero o aspirando, en Mr. Clever se vuelven prácticamente irrealizables. Se puede sumar a todo esto, el hecho de tratarse de comida, foco de ataque para cualquier insecto o roedor, sin olvidar la biodegradación del material y la probable aparición de moho.

Se han dado casos similares en museos y centros, donde las actuaciones han estado muy marcadas por la reposición y la sustitución. Ambas medidas son entendibles en el momento en que se habla de materiales que no están conformados por la mano artesanal del artista y pueden provocar conflictos como los planteados. Por todo ello se opta por soluciones que no provoquen falseamientos muy evidentes ni cambios en la obra. Un buen ejemplo de este tipo de actuaciones es la solución que se dio en la obra Energía de Wolf Vostell, expuesta en el Museo Vostel Malpartida. En esta pieza se realizó la sustitución de una serie de barras de pan que se encuentran envueltas en periódicos y apiladas junto a un coche. Se trata de una obra expuesta de forma permanente en el museo, y como medida de conservación se decidió la sustitución de todas las barras por réplicas realizadas en escayola pintada. La apariencia final respeta al máximo la estética de la pieza, y si no se llega a tocar o se pregunta, el pan parece verdaderamente pan. Se trata de una solución entendible, además de por el gran número de barras, por el fácil mantenimiento de los facsímiles. Estos no serán atacados por insectos -hecho importante tratándose de un museo en medio de la naturaleza- y podrán limpiarse cómodamente con los utensilios adecuados para ello.

Con la sustitución analizada se expone una posible solución, la creación de una réplica con otros materiales que produzcan una forma física que sea igual al original, tanto en color, textura y densidad. Otras obras podrían abordarse desde la sustitución constante de un elemento cuando éste presente algún problema. Así sucede en las piezas de Victor Grippo, en las que la vida del material, en su caso patatas, es fundamental para la resolución de la pieza, ya que la energía que generan los tubérculos es capaz de hacer funcionar distintos elementos electrónicos. Algunas de sus obras se muestran así de sencillas: unas pocas patatas o un gran número de ellas, se conectan a diversos aparatos que funcionan gracias a las mismas. Este hecho obliga irremediablemente al poseedor de la obra a sustituir las patatas que ya estén degradadas y no propulsen el funcionamiento de los elementos seleccionados por Grippo. Realizar una réplica o facsímil en este caso no surtiría efecto y el resultado sólo sería estético pero la pieza no se vería completada. Un caso similar sucede en la conocida obra de Felix Torres Untitled (portraid of Dad) de 1991, en que el artista dispone en una esquina de la sala de exposiciones una montaña de caramelos en cuya cartela se especifica el peso del conjunto: $79,4 \mathrm{Kg}$. El espectador puede tomar del conjunto uno de los dulces, la montaña entonces irá disminuyendo hasta desaparecer. Torres nos hace participes de su amor y su dolor haciendo que contribuyamos en el adelgazamiento de su pareja, viendo cómo se pierde, «adelgaza» y muere.

Cuando nos situamos frente a piezas que presentan una intención interactiva con el público, las medidas a tomar se vuelven complejas y los modos de exposición delicados. Una obra como Chair Event del artista George Brecht, tiene una dinámica interactiva muy marcada pero en muchas ocasiones al ver este tipo de piezas expuestas asistimos a modos expositivos que presentan objetos totalmente inertes, vacíos de toda acción, expuestos sólo para ser mirados. Brecht indaga con sus obras en el mundo de las galerías y los museos, en la forma que en ellas se exponen las piezas, pasando del objeto sacralizado e inmaculado a una obra útil con posibilidad de cambio. Sus sillas se presentan para ser usadas, movidas y variadas, así como los otros enseres que pueden localizarse sobre estas sillas: naranjas, pedazos de pan... Su intención es la participación por parte del público con todo ello, nunca el mostrar las sillas en vitrinas o tarimas que alejan el discurso real 
del contacto con el espectador. Este tipo de obras que presentan una acción necesaria, siempre deben guardar para el futuro los mecanismos óptimos para que sigan funcionando. Las estrategias a diseñar deben pues permitir que la obra siga viva, ya sea reactivando estas acciones y dejando con ello que los objetos sigan degradándose por el usuario o recreándolas por medio, por ejemplo, de replicas de los mismos. Los materiales y objetos que Brecht muestra en sala no pretenden luchar contra el paso del tiempo, por lo que podrían ser sustituidos sin problemas.

\section{Conclusiones}

En el Eat Art, como se ha visto a lo largo del estudio, los alimentos ya no se limitan a ser representados, éstos mismos dan cuerpo a esculturas y espacios por entero comestibles. En ellos, el espectador interacciona no sólo con la vista, también con el olfato, las manos y la boca. Los hermanos Grimm nos presentaban en su cuento a la malvada bruja que intentaba devorar a los pequeños Hansel y Gretel. Con sus dulces creaciones, casas de jengibre, pastel y azúcar, mobiliarios de chocolate y un sinfín de apetecibles invenciones, se concebían obras fantásticas en las que perderse, investigar y deleitarse. La malvada bruja no es otra que Sonja Alhäuser y César Martínez y Dorothée Selz y Leandro Erlich... artistas que se encargan de conformar espacios donde imaginar y repensar la vida [figura 4].

Al igual que los niños perdidos del cuento, estos artistas hacen que el espectador caiga en la trampa, forme parte de su mundo y le ayude a formular sus idearios dando con su participación significado a la obra. Y aunque la transcripción más exacta del Eat Art sea "arte comida», "arte comestible» o "come arte», muchas de las piezas no son necesariamente degustables, y sus creadores intentan mostrar otros aspectos que acompañan a la comida, tales como su frescor, su olor o el paso del tiempo sobre materias altamente degradables. El trabajo de Manzoni, Jana Sterbak, Dieter Roth o Victor Grippo, coinciden en emplear comida real pero ninguno lo hace con la misma intención. Cada creación guarda componentes diversos y responden en el tiempo y al lugar de forma diferente. Mientras que Manzoni o Grippo pretenden presentar los alimentos siempre frescos, vivos y con aspecto saludable, Dieter Roth o Antony Gormley se interesan en exhibir lo putrefacto y revelar la destrucción de lo vivo. Posiblemente sería más acertado en todos estos casos hablar de Food Art «arte con alimentos», pero aún así el término Eat Art hace referencia al empleo de comida real para conformar la pieza de arte y así es como se ha entendido en el presente proyecto, para con él dar soluciones en la formación de estrategias de conservación de estas complejas piezas.

Existen como se ha expuesto, diferencias generales y específicas entre unos tipos de obras Eat Art y otras. Esta disparidad ha dado como resultado una tabla [tabla 2], resultado final y conclusión del estudio. Como respuesta a todas las problemáticas expuestas se diseñaron soluciones que podrían darse a cualquiera de los tipos de obras y a sus diferentes conflictos. Se barajaron actuaciones muy diversas con las que el restaurador puede hacer perdurar, reactivar o incluso re-interpretar las obras, siendo en todos los casos opciones e ideas que han sido trazadas de forma teórica, funcionando como guía para actuar de una manera u otra respecto a su función y finalidad. 


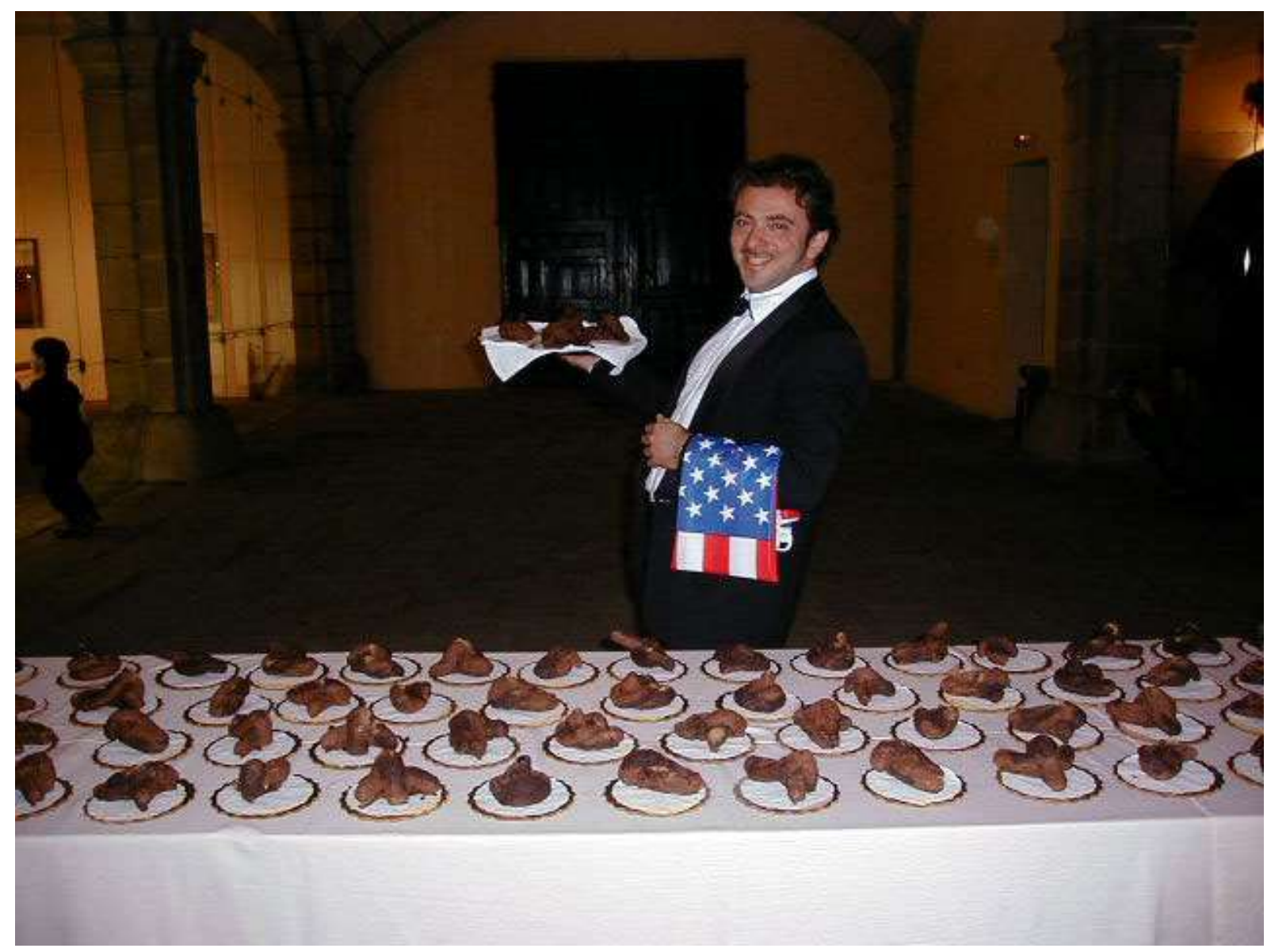

Figura 4. Como luego existo, existo luego como, César Martínez. Esculturas con forma de excremento realizadas con chocolARTE, mazapanes, turrón y esencia de tequila que el público de la exposición degustó y saboreó durante la inauguración. 2002. @Antoni Abad.

Cabe señalar que con la variedad de materiales y procederes vistos, sería impracticable tratar de realizar un panorama detallado al milímetro de las distintas soluciones que la conservación y restauración pueden dar. Por eso la intención se centra en realizar un esquema claro y conciso donde queden reflejados todos los tipos de obras Eat Art que puedan existir, reduciéndose estos a tres tipologías: Obras de carácter duradero, Obras de carácter perecedero y Obras que implica una acción artística. Tras ello se indica cual puede ser su función y finalidad respecto a ese carácter, ya sea funcional y visual, solamente estético o de interacción, e incluso degradación máxima. De este modo, obras como Mr. Clever, con presencia real de comida, presenta una intención únicamente visual y sumado a ello no posee ningún interés en mostrar la degradación de la crema ni por tanto su desaparición. Siguiendo el recorrido en la tabla, las posibles estrategias a aplicar serían la reposición o sustitución y la recreación. Al igual sucede con la obra Energía de Vostell, pero a diferencia de éstas, las patatas de Grippo instan a una estrategia muy clara, la sustitución. Cualquier otra opción no permitiría el funcionamiento de la obra. De modo similar ocurriría al desarrollar una réplica en otro material de los caramelos de Félix Torres, lo que imposibilitaría que el público participase en la disminución y desaparición de su montaña de dulces.

A modo de colofón y nexo entre la introducción del artículo, cabe retomar la cita con que se inició la explicación del estudio abordado, perteneciente al fabuloso recetario de Marinetti, La Cocina 
Futurista: Una comida que evitó un suicidio. En ella quedaban esbozados los acontecimientos que se sucedieron en casa de uno de los compañeros del artista, Giulio Onesti, y los motivos que les llevaron a crear un muestrario de mujeres comestibles. Con el transcurso de la historia se van desgranando más datos sobre la obra en cuestión, pero sería interesante resaltar otro magnifico momento, en que una mujer real irrumpe en la sala donde aguardan los amigos junto a la obra comestible ya acabada: No me toméis por necia -murmuró con gracia lánguida estoy atontada. Vuestro ingenio me espanta. Os suplico que me Expliquéis las razones, las intenciones, los pensamientos que os han dominado mientras esculpíais tantos delicioso olores, sabores, colores y formas (Marinetti 1985:19).

Extrañada por lo observado en la sala, la mujer sorprendida no entiende lo que ve e instintivamente pide explicaciones a sus creadores. Dejando aparte la sugestiva respuesta con que Marinetti deslumbra a la confundida mujer, tomemos la historieta y todo lo acontecido como metáfora, como un símbolo o alegoría de la situación del restaurador-conservador frente a la obra contemporánea hecha con comida. Este conflicto es el detonante que dio pie a la realización del estudio que aquí presento de forma escueta. Mi intención es esclarecer los interrogantes que presenta, en mayor medida si cabe, para los encargados de preservar dichas creaciones. Somos responsables, en todos los aspectos, de su estado para con el futuro y de que el público que acuda a deleitarse con estas creaciones, denominemos atípicas, sigan disfrutando correctamente de una pequeña parte del vasto catálogo artístico de nuestros días.

\section{BIBLIOGRAFÍA}

AZNAR ALMAZÁN, S. (2000). El arte de acción. San Sebastián: Editorial Nerea.

BAIGORRI BALLARÍN, L. (1997). El video y las vanguardias históricas. Barcelona: Ed. Universitat de Barcelona.

BRILLANT-SAVARIN, J.A. (2001). Fisiología del gusto. Barcelona: Editorial Optima.

BERMEJO BARRERA, J.C. GONZÁLEZ GARCÍA, F. J. y REBOREDO, S. (1996). Los orígenes de la mitología griega. Madrid: Ediciones Akal.

BROWNING, W.R.F. (2006). Diccionario de la Biblia: Guía básica sobre los temas, personajes y lugares bíblicos. Barcelona: Ediciones Folio.

BUSTINDUY, P. (2005). "La presencia de alimentos en obras de arte. Problemas para su conservación", en VI Reunión del Grupo de Arte Contemporáneo del GEIIC. Madrid: Grupo Español del IIC, Museo Nacional Centro de Arte Reina Sofía, 95-100.

CHARLESP, V. (2011). Naturaleza Muerta. Londres: Parkstone International.

ESPÍN CÁNOVAS, D. (1997). Los derechos de autor de obras de arte. Madrid: Cívitas.

BERCOVITZ, G. (1997). Obra plástica y derechos patrimoniales de su autor, Madrid: Tecnos.

GOUGH, R. (1999). On Cooking: Performance Research, UK: Routledge.

HEUMAN, J. (1995). From marble to chocolate: the conservation of modern sculpture. Londres: Tate Gallery Conference, 18-20 September.

OGDEN, J. (2005). Psicología de la alimentación. Madrid: Morata.

KORSMEYER, C. (2002). El sentido del gusto: comida, estética y filosofía. Barcelona: Paidos Transiciones.

GOMBRICH, E.H. (2006). La Historia del Arte. Madrid: Debate.

SERRERA CONTRERA, J.M. Y VALDIVIESO, E. (1985). Historia de la Pintura Española: Escuela Sevillana del Primer Tercio del Siglo XVII. Madrid: Instituto Diego Velázquez: Consejo Superior de Investigacione Científicas. 
MARINETTI, F. T. (1985). La cocina futurista: una comida que evitó un suicidio. Barcelona: Gedisa.

MUÑOZ VIÑAS, S. (2003). Teoría Contemporánea de la restauración. Madrid: Editorial Síntesis.

PASCUAL ANDERSON, M. DEL R., CALDERÓN Y PASCUAL, V. (2000). Microbiología Alimentaria: Metodología Analítica para Alimentos y Bebidas. Madrid: Editorial Diaz de Santos.

RIGHI, L. (2006). Conservar el Arte Contemporáneo, San Sebastián: Editorial Nerea.

ROTAECHE, M. (2010). Conservación y restauración de materiales contemporáneos y nueva tecnologías. Madrid: SINTESIS.

ROUTH, J. Y ROUTH, S. (2009). Notas de cocina de Leonardo Da Vinci. Madrid: Temas de Hoy.

STANGOS, N. (2000). Conceptos del arte moderno. Barcelona: Ediciones Destino.

TATARKIEWICZ, W. (2004). Historia de la estética III: La estética moderna 1400-1700. Madrid: Akal.

VV.AA. (2002). Comero no Comer. Salamanca: Ed. Centro de Arte de Salamanca (CASA).

VV.AA. (2011). Conservación de Arte Contemporáneo 8a Jornada. Madrid: MNCARS Versiones del sur.

VV.AA. (2011). Conservación de Arte Contemporáneo 11 a Jornada. Madrid: MNCARS Versiones del sur.

VV.AA. (2011). Conservación de Arte Contemporáneo 12a Jornada. Madrid: MNCARS Versiones del sur.

VV.AA. (1996). ¿Deshumanización del arte?, Salamanca: Universidad Salamanca.

VV.AA. (2009). Eating the Universe: Vom Essen in der Kunst, Kunsthalle Düsseldorf: Editorial DuMont.

VV.AA. (2009). Martha Rosler: la casa, la calle, la cocina. Madrid: Centro José Guerrero.

VV.AA. (2010). Miralda de gustibus non disputandum. Madrid: La Fábrica Editorial.

VV.AA. (2010). No es sólo lo que ves: pervirtiendo el minimalismo. Madrid: MNCARS Versiones del sur.

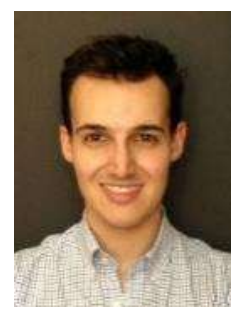

Lorenzo Hortal Valverde

hortalv@gmail.com

Lorenzo Hortal Valverde, licenciado en Bellas Artes por la Universidad Complutense de Madrid con especialidad en Restauración y Conservación de pintura. Magíster en Restauración y Conservación de Arte Contemporáneo (UCM y MNCARS). Ha realizado prácticas en el departameno de restauración del Museo Nacional Centro de Arte Reina Sofía. Actualmente y desde 2011 trabaja en el estudio/cono I\&R S.C. en la restauración y estudio de pintura de caballete mediante el tratamiento directo de las obras y su estudio analítico en laboratorio. Compaginándo esta labor con su colaboración en Nicolas Lemmens Studio, Bruselas, tratando exclusivamente obra contemporánea.

Artículo enviado el 31/01/2013

Artículo aceptado el 28/05/2013 


\title{
Cleaning plaster surfaces with agar-agar gels: evaluation of the technique
}

\author{
Sonia Tortajada Hernando, Manuel María Blanco Domínguez
}

\begin{abstract}
Cleaning plaster surfaces represent a challenge for conservators. It should only be performed following fully tested methods that guarantee the conservation of such fragile material. The goal of this work is to establish a suitable cleaning method for this type of artwork from the tested concentrations and time of applications, using agar gels on plaster supports.

Morphological, porosity and weight variations have been studied. Confocal and stereomicroscopy have been used as analytical techniques, as well as the measurement of water vapor permeability and weight have been taken on the samples.
\end{abstract}

Key words: agar, gypsum, plaster, gels, cleaning.

\section{La limpieza de superficies de yeso-escayola con geles de agar-agar: evaluación de la técnica}

Resumen: La limpieza segura y eficiente de las superficies de yeso constituye un reto y una responsabilidad para el conservador-restaurador, y debe llevarse a cabo siguiendo métodos testados que garanticen su correcta conservación. La intención de este trabajo es determinar, a partir de las concentraciones y tiempos de aplicación ensayados, cuáles serían los parámetros óptimos para la ejecución de una limpieza eficaz e inocua empleando geles de agar-agar sobre soportes de yeso.

Se han comprobado las posibles variaciones morfológicas de la superficie, las variaciones de la porosidad y del peso, así como la presencia de residuos, para lo cual se ha empleado la microscopía confocal, microscopía binocular, la medida de la permeabilidad al vapor de agua y la medida del peso de las muestras.

Palabras clave: agar, yeso, escayola, geles, limpieza.

\section{A limpeza de superfícies de gesso com géis de agar-agar; avaliação da técnica}

Resumo: A limpeza segura e eficiente das superficies de gesso constitui um desafio e uma responsabilidade para o conservador-restaurador e deve ser levada a cabo seguindo métodos testados que garantam a sua correcta conservação. O propósito deste trabalho é determinar quais serão os parámetros óptimos para a execução de uma limpeza eficaz e inócua sobre suportes de gesso, a partir das concentrações e tempos de aplicação de géis de agar-agar.

Verificaram-se as possiveis variações morfológicas da superficie, as variações da porosidade e do peso, assim como a presença de resíduos, tendo sido empregue a microscopia confocal, a microscopia binocular, a medida da permeabilidade do vapor de agua e a medida do peso das amostras.

Palavras-chave: agar-agar; gesso, géis, limpeza.

\section{Introduction}

Cleaning plaster surfaces is challenging. It should only be performed following fully tested methods that guarantee the conservation of such fragile material. Establishing a suitable cleaning method for this type of artworks is indeed very challenging to say the least. 
Existing cleaning methods have been problematic when used on plaster. Considering the physicochemical properties of this type of surfaces, and a cleaning procedure pursuing selectivity and respect to the integrity of the artwork, aqueous solutions are usually not a viable option because plaster is partially soluble in water, so any moisture accompanied by the slightest removal action can wear away the surface causing irreversible alteration of its original qualities. Besides water solubility, plaster surfaces are extremely fragile. They can be easily eroded by the action of a cotton swab and do not usually react well with the direct contact of poultices, so cleaning options are very limited.

The research conducted by Dr. Cremonesi and his team have served as a starting point for this study. They have worked on the use of agar in conservation and their experiences are published in two "Cuadernos" by Cesmar7 (Centro per lo Studio dei materiali per il restauro) (Cremonesi et al. $2007,2008)$. In this article agar is presented, as an alternative cleaning method. Agar is the dry extract obtained from several kinds of rodophicea algae, with a great gelling power that when used in its gel form is capable of supplying water in an extremely controlled way, allowing aqueous cleaning of porous surfaces, such as plaster, in an efficient and innovative way, while conserving the intrinsic characteristics of the substrate. Their first tests were run using rigid agar gels but soon they started to use agar in a viscous liquid phase so they could be applied to tri-dimensional objects. The results of cleaning on plaster objects were very promising, providing appropriate levels of cleanliness, while treated surfaces seemed to show no signs erosion when observed with optical microscopy, or any other sign of alteration.

However, it was considered necessary to conduct a thorough study of how these surfaces could be affected by contact with these aqueous gels, considering the frailness and water solubility of the material.

In this research we have systematically studied plaster surfaces, in terms of porosity and morphology variations, and presence of residues, that have been treated with agar gels at different concentrations and application times by observation with confocal microscopy (topographies and profiles, with micron resolution), and performing water vapor permeability test, before and after each treatment. The study was designed so that variations in weight of the treated samples. Observations were made under stereoscopic microscope (x40, x25, x16) under white and ultraviolet light, to be able to evaluate this cleaning technique with a scientific approach.

\section{Objectives}

The intention of this paper is to determine, based on the concentrations and application times tested, what would be the optimal parameters of a safe and efficient cleaning procedure using agar-agar gels on gypsum, specifically in terms of:

- Morphological changes on the surface.

- Porosity changes.

- Presence of residues.

To establish damage threshold parameters concerning:

- Concentration.

- Application time. 


\section{Methodology}

The tests should be designed to assess and interpret the results obtained away from subjectivity. Parameters that may vary like the type of dirt, particular surface characteristics and operator skills should be avoided. This means that the samples for this research were made following the same procedure, using the same plaster material and plaster/water ratio, and were left unstained, so they would all have similar surface characteristics. All the tests were performed on unsoiled plaster taking under account cleaning efficiency was not to be assessed in this study.

Two types of samples have been used: samples specifically made for this study and some real fragments, to better illustrate the results.

For the sample specifically made for this study, a total of 21 samples were selected. These samples were plaster discs of $6 \mathrm{~cm}$ in diameter and a thickness between 10 and $13 \mathrm{~mm}$. They were made using two similar water-solid mixes that once hardened needed to be dry before testing started. They were left to air dry for two weeks and then placed into a drying chamber with silica gel for two months to eliminate the maximum amount of water possible. A drying stove was not used to speed up the drying process due to the low temperature of calcination of calcium sulphate (around $100^{\circ} \mathrm{C}$ ) to avoid the risk of molecular dehydration.

Alamo 50 gypsum ${ }^{1}$ was used for the making. This gypsum is considered "plaster quality". This material was selected because it is the one currently used by the Casting Workshop of the Royal Academy of Fine Arts of San Fernando to make their casts.

To better illustrate how the cleaning procedure works, some tests have been conducted on real plaster cast objects. They are fragments donated by Professor Pedro Terrón from the School of Fine Arts modeling workshop at Universidad Complutense of Madrid. They all showed abundant surface pollution and clay deposits.

For the cleaning tests, we worked with two concentrations of agar gels: $2 \%$ and $4 \%(\mathrm{w} / \mathrm{v}$ ) in distilled water. The gels were made using Agar-agar (UPS) PRS-CODEX 141792.1209 from the commercial firm Panreac, prepared with $4 \mathrm{~g}$ of powder in $196 \mathrm{ml}$ distilled water $(2 \mathrm{~g}$ in $98 \mathrm{ml} \times 2$ for the $2 \% \mathrm{gel}$ ) and analogously using 8 grams of dry powder in 192 milliliters of distilled water ( $4 \mathrm{~g}$ in $96 \mathrm{ml}$ x 2, for the $4 \%$ gel). The water was then heated up to $85-90^{\circ} \mathrm{C}$. At that temperature agar will dissolve in water, so the powder is poured in the liquid and allowed to dissolve for about 5 minutes, stirring with a glass rod. This mixture is left to cool and reheated a second time at $90^{\circ} \mathrm{C}$ to ensure the dissolution has been complete. It is then poured into a beaker and allowed to cool until a hard gel is formed.

Agar gels can be used in a broad temperature range depending on the degree of gelling required, so this will allow for gels to be applied as a viscous liquid using a brush. The higher the temperature, the more fluid the mixture will be, and as temperature decreases there is an increase in the viscosity until the mixture becomes rigid around $35^{\circ} \mathrm{C}$. To make a successful application by brush the ideal temperature is about $40-45^{\circ} \mathrm{C}$ (measured with a thermometer.) To the touch the mixture is perceived as lukewarm. At this temperature it could be considered safe to use on most materials that make up the artwork. After waiting for the application time established according to the tests, the gels are then removed.

On the test samples $2 \%$ and $4 \%$ agar gels were applied with three different application times: $1 \mathrm{~T}=$ 2 minutes, $2 T=20$ minutes, and $3 T=24$ hours(totally dry). Each treatment was applied on groups 
of three different samples. For the real fragments a $2 \%$ concentration was always used, with application times of 2, 5, 10, 20,30 minutes and 24 hours (totally dry). Also a treatment based on two successive applications of 2 minutes was tested for the 2 minutes application.

The disc samples are identified by the concentration of agar gel used and application time in each case. For example "sample $2 \% \mathrm{~T} 1$ " would indicate that $2 \%$ agar gel has been applied, and it was left on the surface for 2 minutes. Table I shows the different treatment conditions tested on the plaster disc samples.

Table I. Different treatment conditions tested on the plaster disc samples.

\begin{tabular}{|l|l|}
\hline $\begin{array}{l}\text { Sample } \\
\text { Code }\end{array}$ & $\begin{array}{l}\text { Treatment description } \\
\text { (applied on three samples each) }\end{array}$ \\
\hline $2 \% 1 \mathrm{~T}$ & Agar concentration $(\mathrm{W} / \mathrm{v}) 2 \%$ applied during 2 minutes. \\
\hline $2 \% 2 \mathrm{~T}$ & Agar concentration $2 \%$ applied during 20 minutes. \\
\hline $2 \% 3 \mathrm{~T}$ & $\begin{array}{l}\text { Agar concentration } 2 \% \text { applied during } 24 \text { hrs or totally } \\
\text { dry. }\end{array}$ \\
\hline $4 \% 1 \mathrm{~T}$ & Agar concentration $4 \%$ applied during 2 minutes \\
\hline $4 \% 2 \mathrm{~T}$ & Agar concentration $4 \%$ applied during 20 minutes \\
\hline $4 \% 3 \mathrm{~T}$ & Agar concentration $4 \%$ applied during 24 hrs or totally dry \\
\hline
\end{tabular}

The treatments effects have been characterized using different observation techniques and test methods. Before any treatment was applied, the material under study has been characterized. The observation techniques used were optical confocal microscopy, the stereomicroscope under white light and ultraviolet light. The water vapor permeability and weight of samples was also measured (both tests reflect permeability and weight variations undergone by the samples after each treatment). 
The Confocal Scanning Microscopy (CSM) provides roughness measurements (Ra), height variations allows for the observation of microcracking of the surface of the samples. This microscopy system performs three-dimensional reconstructions of the surface topography with a vertical resolution of hundreds of nanometers and a lateral resolution varies depending on the lens used $\left(x 10 \_0,935 \mu \mathrm{m} ; \times 20 \_0,623 \mu \mathrm{m} ; \times 50 \_0,350 \mu \mathrm{m}\right)$. Allowing to fully document the surface roughness through images, profiling and numerical values. Ra described as the arithmetic mean of the absolute departures of the roughness profile from the mean line was used in this study, since this value is a universally accepted surface roughness value and appropriate for evaluating the effect of factors on the surface quality (Yavuz et al. 2011). The equipment used was Confocal Imaging Profiles Sensofar PL N 2300, with PL N Version 2.1 software based on Windows 2000/XP. The lenses used were $\mathrm{x} 10$ for data evaluation and $\times 20$ for detail image in figure I.

And initial measurement was taken on one sample from each treatment (a total of six measurements because six different treatments conditions were being tested). After each treatment a second roughness measurement was taken on the surface of the same sample, selecting a representative surface area $\left(4.4 \mathrm{~mm}^{2}\right)$ in every case. Also in treatments where large variations occur additional measurements were taken to better record them.

The water vapor permeability test was performed using as reference standard from the Italian legislation, NORMAL 21-85. The test was performed on groups of three samples, before and after treatment. The conditions during the test were of an average temperature of $20^{\circ} \mathrm{C}$ and chamber gradient (wet-dry) Relative Humidity (RH) of 59\% (RH 90\%-RH 31\%). We applied a thickness correction factor in all samples, and we express permeability values in $\mathrm{g} /(\mathrm{m} \times 24 \mathrm{~h})$.

Permeability is the ability of a material to transmit through its mass liquids, gases or mixtures of both, under the action of a pressure gradient (Gisbert 2002: 179). This property is related to the porosity and the connectivity of voids (Esbert 1993). Permeability is a characteristic of each material and varies in the untreated material in relation to the treated one. It gives an idea of the extent to which the pores have been clogged due to the presence of residues of different materials or treatments (Gomez Terreros 2000: 33-51), due to the modification of the material surface, variations in roughness, and may also cause changes in the permeability thereof. This data is important to define the ability of the material to "breathe", how easily the moisture retained inside flows to the outside.

The test specimens were weighed before and after the application of the different treatments, with an accuracy of $10^{-4}$ grams, to assess the loss or gain in weight of the samples after each type of intervention. A scale Mettler Toledo 48206/TACT was used for such measurements.

We have also observed that the samples with long-wave ( $365 \mathrm{~nm} ; 6 \mathrm{~W}$ ) and shortwave ( $254 \mathrm{~nm}, 6 \mathrm{~W}$ ) ultraviolet light, both directly and through stereomicroscope with 16, 25 and 40 magnifiers, with the intention, given the different response given by the support material (gypsum) and agar under this illumination, to determine the presence of residues after the treatments. The quantification of residues has been calculated on the UV visible images of the complete surface of the samples managed with a digital imaging treatment software that allows taking surface area measurements to estimate the presence of residues. These remains appear as very thin films in the peripheral areas. They can be removed using a scalpel. 


\section{Discussion of results}

The initial appearance of the sample surfaces prior to any treatment is shown in Figure I. The surface is matte, despite being quite polished, and you can see lines (polishing grit) and pores (setting bubbles). For these surfaces the average roughness (Ra) ranging between 1- 1.5 $\mu \mathrm{m}$.

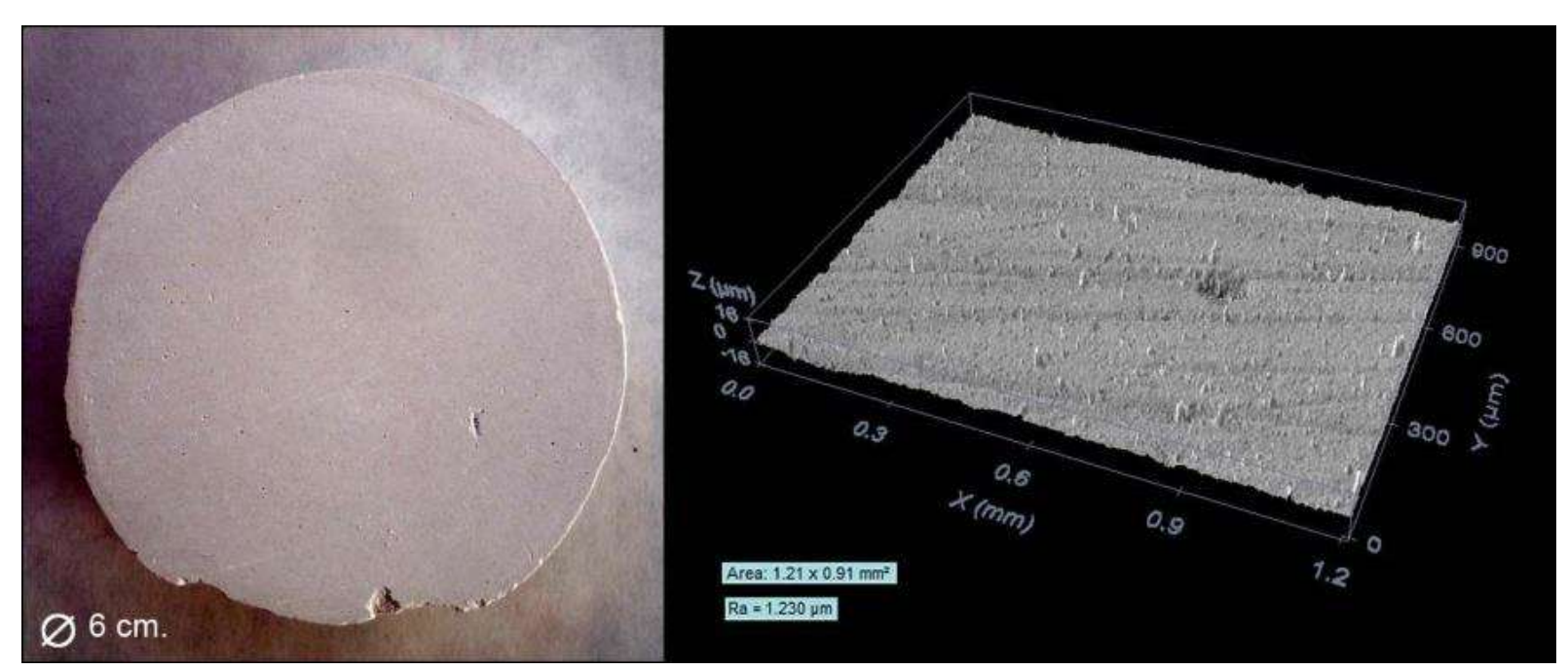

Figure I: Left: Plaster surface. Right: confocal detail topography (x 20) of the sample on the left, in which a pore, polishing scratches and dust particles can be seen on the surface.

For the water vapor permeability the initial average value was calculated for the plaster samples: $1.8 \mathrm{~g} /$ ( $\mathrm{x} 24 \mathrm{hrs}$ ) with a coefficient of variation of approximately $8 \%$.

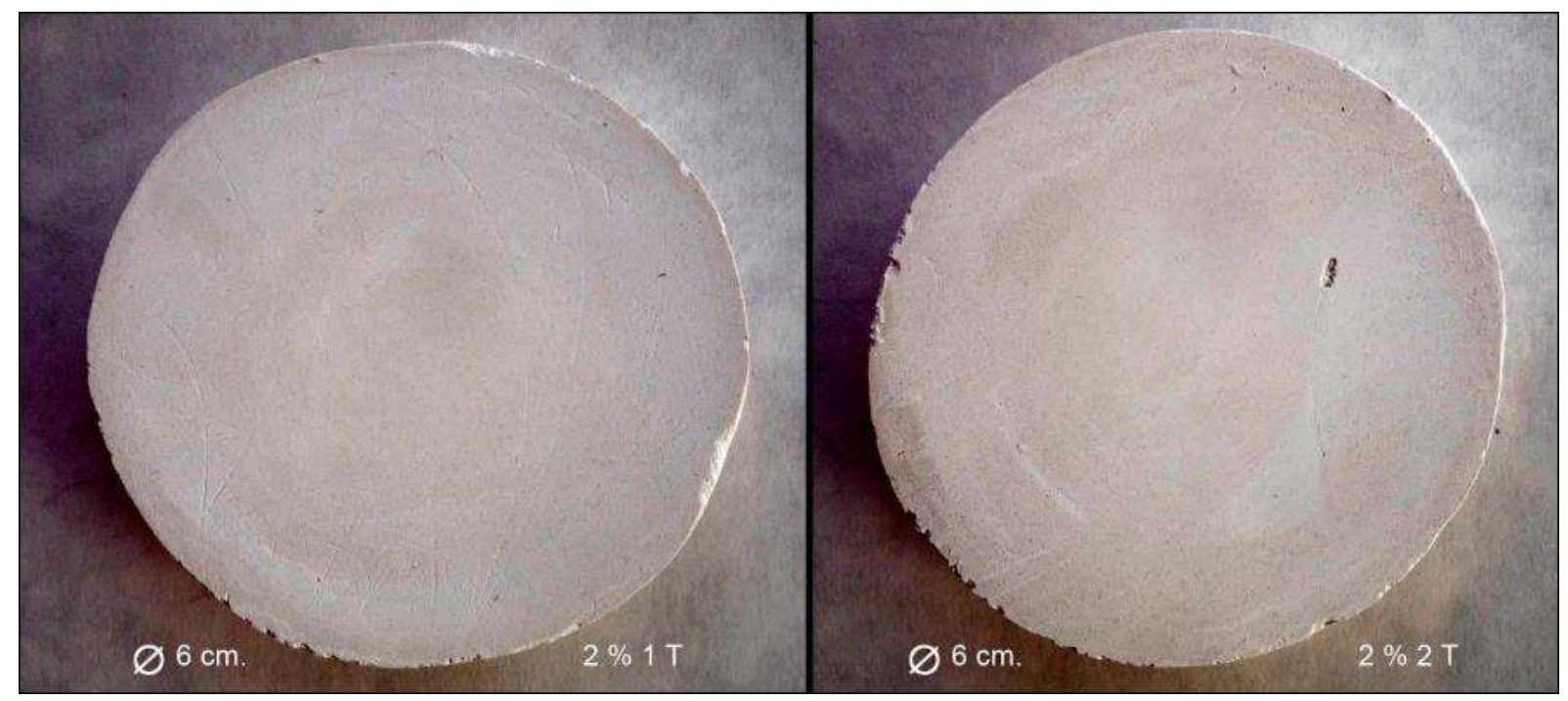

Figure II: Left: Surface appearance of a sample 2\% 1T. Right: Surface appearance of a sample 2\% 2T. 
Figure II shows the surface of the samples treated with agar gel at $2 \%$ concentration left for 2 minutes on the surface (left) and 20 minutes (right). Such treatments have caused no changes in the surface roughness of the samples, detectable by the measurement method used. Variations in permeability values of the samples tested after both treatments are less than $2 \%$, not finding a clear trend of variation. Due to the negligible variation (and the lack of trend) we can consider that the changes in permeability caused by these treatments are not significant. Samples treated with $2 \%$ agar for 2 minutes, present no residues or loss of material on the surface. In the case of the 20 minutes application, the material loss is less than $0.01 \mathrm{mg} / \mathrm{cm}^{2}$ (may be considered negligible) and residues present on the specimen waste samples cover between $0-4 \%$ of the material surface.

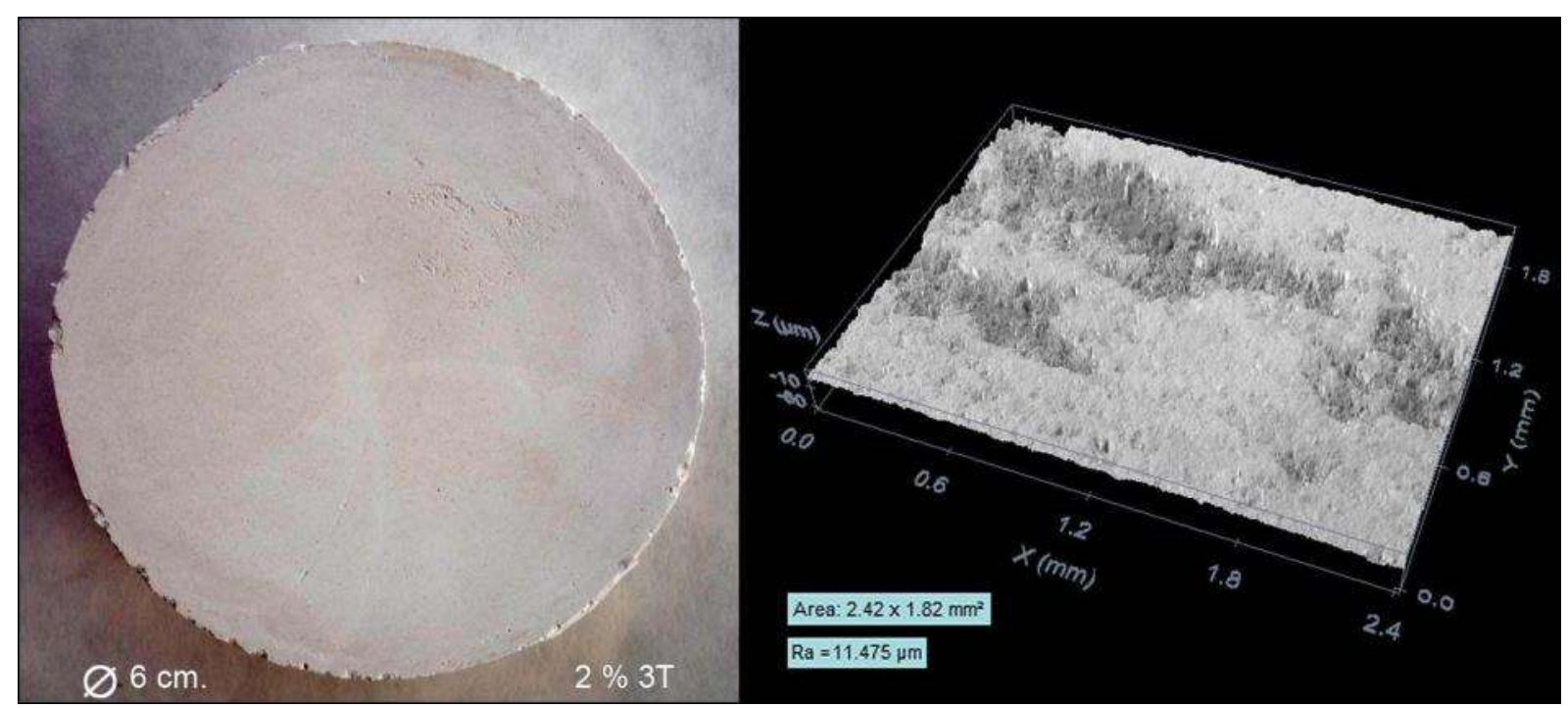

Figure III: Left: surface appearance of sample 2\% 3T. Right: confocal topography $\left(x 10 ; 4.4 \mathrm{~mm}^{2}\right)$ of the upper central area of the sample to the left where material has been lost.

In Figure III we can see the surface of a sample treated with $2 \%$ agar gel concentration left to dry completely. Overall, the roughness of the treated samples under these conditions is very similar to the initial values, but we can observe local areas where there has been an increase in roughness by removal of material. In these areas the roughness values can reach $11.5 \mu \mathrm{m}$ [Figure III, right image]. Concerning permeability values after treatment, the variations are less than $1 \%$ and do not show a clear trend. The weight losses are less than $0.1 \mathrm{mg} / \mathrm{cm}^{2}$ (average value could be considered small). The presence of residues following the application is estimated between $4-6 \%$ of the sample surface, of all treatments tested this is the one leaving more residues behind. As in previous cases the residues appear as thin films on the edges, and are easily removable.

So far we have not discussed the relevance of residue of such a product like agar remaining on the surface. The evolution of these residues is closely linked to atmospheric moisture. In high humidity conditions the evolution of these films could be extremely harmful as they will surely develop heavy biological colonization. In Figure IV the appearance of such biological colonization of the agar gel films in treatment $2 \% 1 \mathrm{~T}$ is shown, thirty days after being removed from the surface a plaster sample, kept on filter paper inside a plastic bag. 


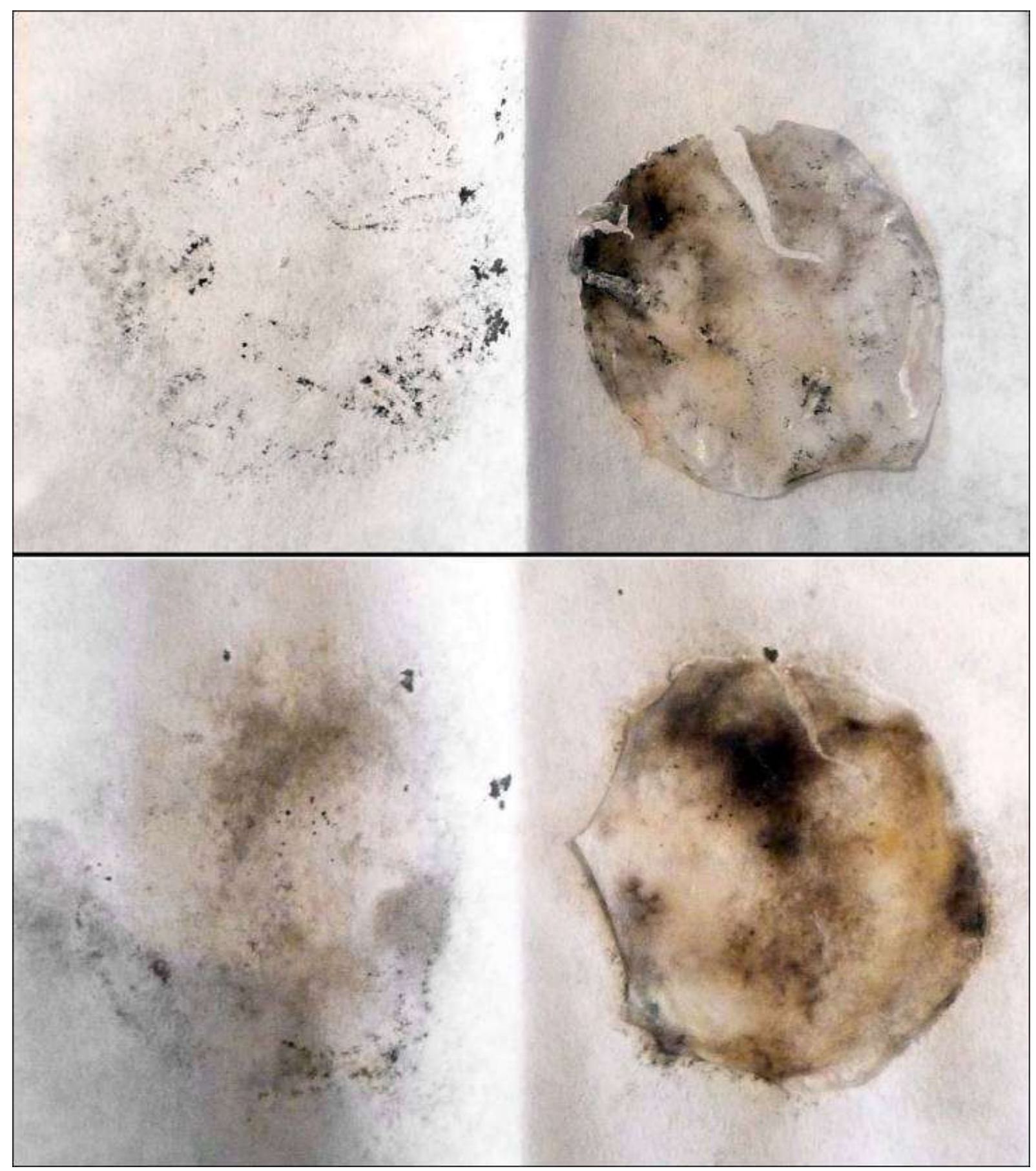

Figure IV: Left top and bottom: filter paper with traces of mold. Right top and bottom: agar film $2 \% 1 \mathrm{~T}$ treatment after thirty days of application and removal.

On Figure $V$ we can see a sample treated with $2 \% 3 T$ under long-wave ultraviolet light. This is the sample on which confocal images were taken and roughness measured. The agar film response can be clearly seen in pale yellow colour, compared to the pinkish tone of plaster. 


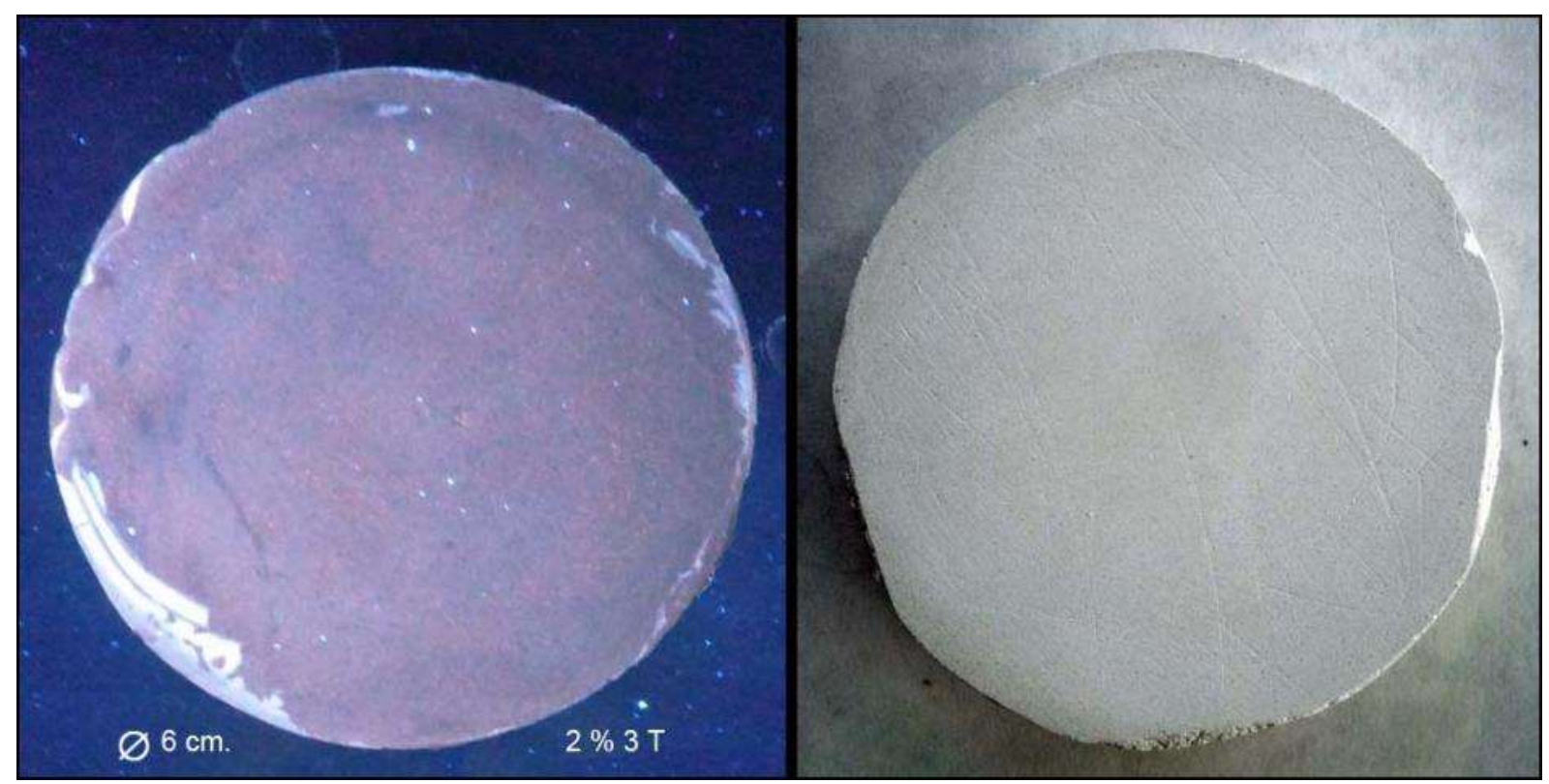

Figure V: Left: image of the surface of a sample treated with $2 \% 3 T$, under long wave ultraviolet light. Right: the surface appearance of a sample treated with $4 \% 1 \mathrm{~T}$.

In treatments with $4 \% 1 \mathrm{~T}$ roughness changes have not been detected and variations in the permeability of the samples are around $1 \%$, with no clear trend. The loss in weight is less than 0.1 $\mathrm{mg} / \mathrm{cm}^{2}$, and the remnants of the gel are between 0 and $2 \%$ of the sample surface, with a similar location to the above cases.

Treatment with 4\% 2T [Fig. VI] has caused an increase in surface roughness of the sample. In general roughness values are around 3 microns with peak values reaching $7 \mu \mathrm{m}$ (center-top of the sample).

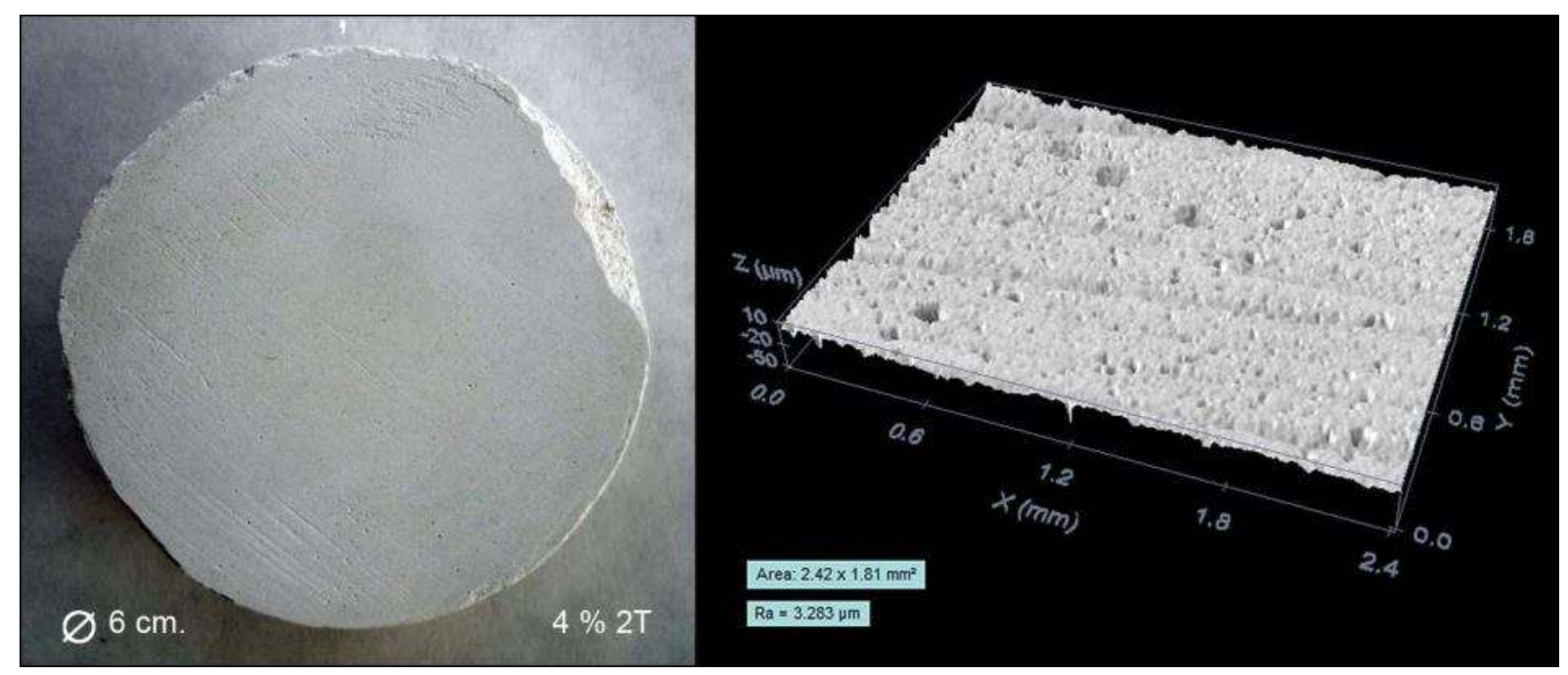

Figure Vl: Left: surface appearance of sample 4\% 2T after treatment. Right: confocal topography (x 10; 4.4 $\mathrm{mm}^{2}$ ) of the same sample surface. 
The overall increase in roughness is due to the loss of small amounts of material that occurs preferably on preexisting grooves and bubbles, making them bigger. Rougher areas correspond to where there has been further loss of material. Even so, the loss of material per unit area remains small (less than $0.1 \mathrm{mg} / \mathrm{cm}^{2}$ ). Regarding permeability, with this treatment variations close to $8 \%$ have occurred, having a clear negative trend. This decrease in the permeability begins to be significant. The surface residues location is similar to the previous cases and its extension is $2-4 \%$ of the sample surface.

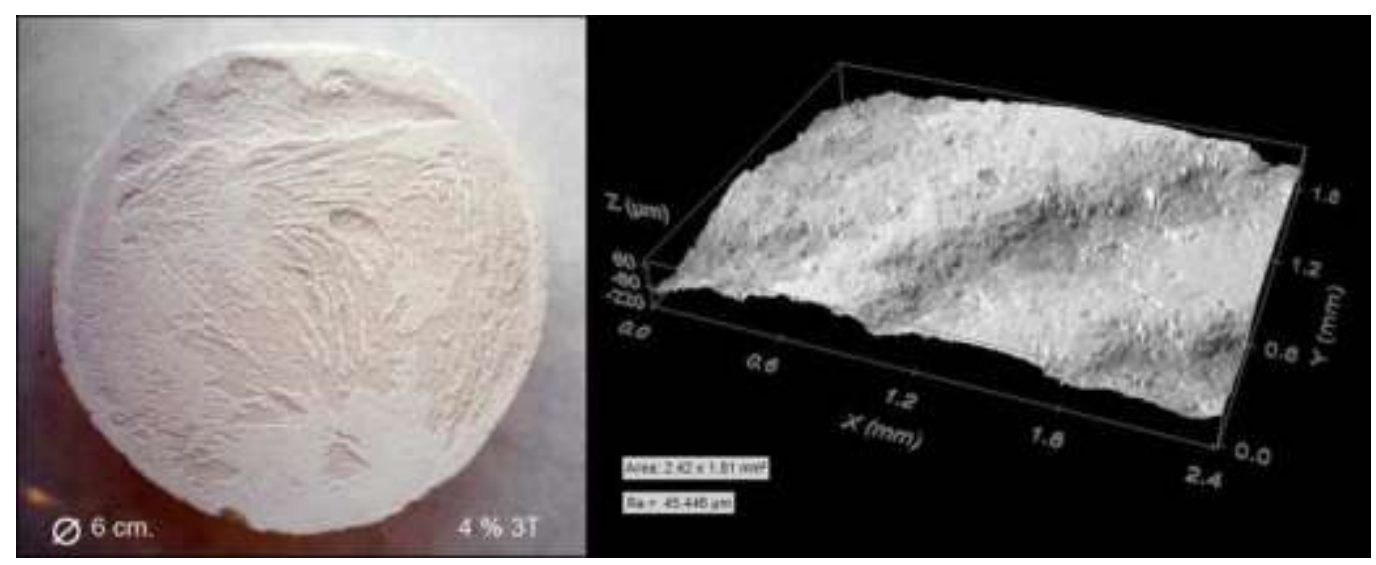

Figure VII: Left: surface appearance of sample 4\%3T after treatment. Right: confocal topography (x10; 4.4 $\mathrm{mm}^{2}$ ) of the same sample.

In figure VII we can see the effects of treatment $4 \% 3 \mathrm{~T}$ on the sample surface. As seen in the photograph, this treatment has proved to be frankly aggressive, the samples reaching roughness average values at around $45 \mu \mathrm{m}$, with areas in which this value may increase to about $150 \mu \mathrm{m}$. In some points a vertical drop of around 500 microns has been observed.

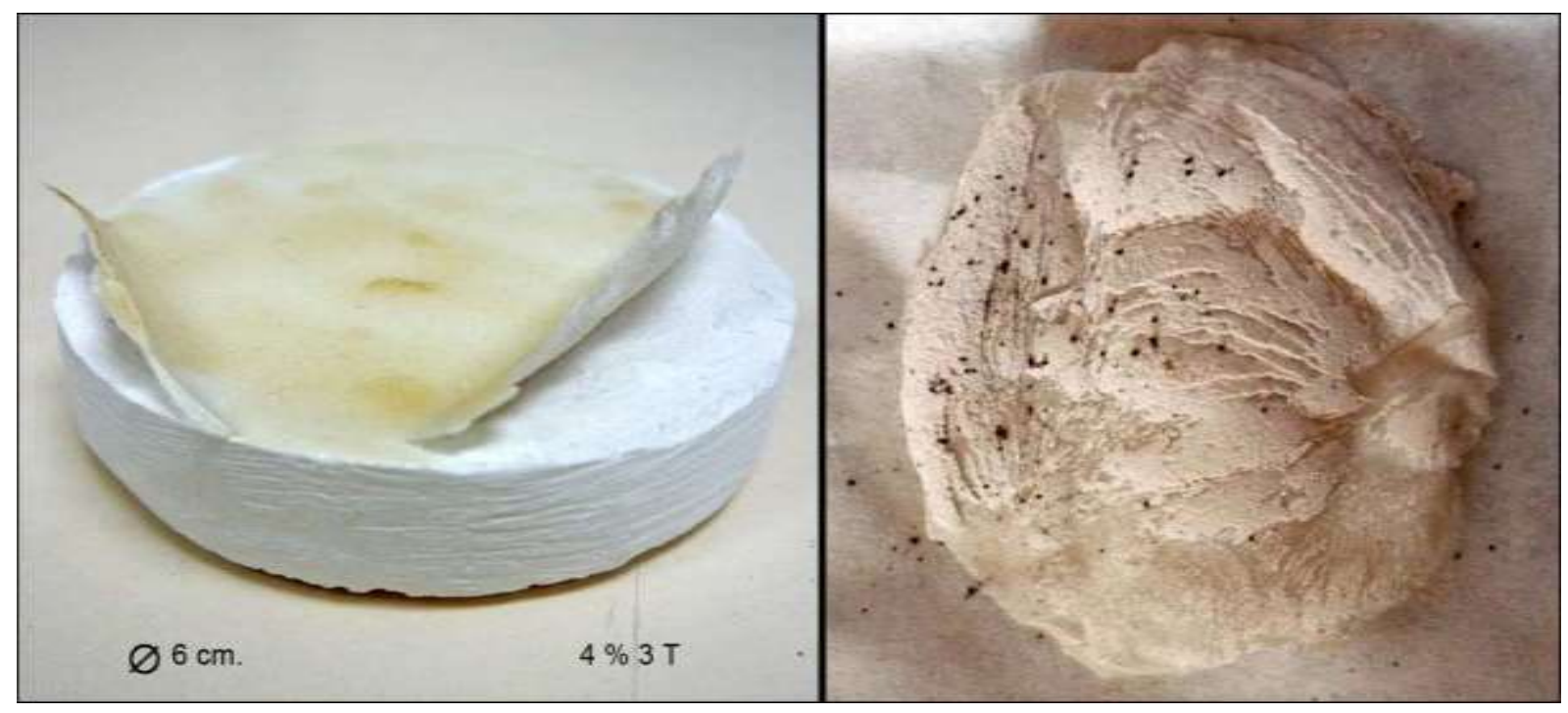

Figure VIII: Left: appearance of the sample treated with agar film 4\%3T, showing the retraction of the agar layer. Right: agar film once removed from the surface of the sample with quite a lot of plaster and some fungi (black dots). 
Again a decrease in water vapor permeability occurs. In this case it is around $12 \%$. The material losses are significant $\left(4.74 \mathrm{mg} / \mathrm{cm}^{2}\right)$, the shrinkage and strappo capacity of the treatment under these conditions should be emphasized. Remaining residues cover approximately $4 \%$ of the sample surface with a similar distribution to the above. Notice that the black spots on Figure VIII right, have appeared within thirty days after treatment, when the film was removed and stored on filter paper in a plastic bag. There is quite a difference in the intensity of the biological colonization on this sample compared to the samples previously seen, which could be due to variations in humidity.

To better illustrate how the cleaning procedure works, some tests have been conducted on real plaster cast fragments [Figure 9]. They all showed abundant surface dirt and clay deposits. For these tests we used a concentration gel of $2 \%$, with application times of $2,5,10,20,30$ minutes and 24 hours (totally dry).

On these samples soil does not appear as separate layer. Under the optical microscope we can see it as pores filling (decreasing surface roughness) and in some areas as patches (areas up to $2 \mathrm{~mm}^{2}$ ) between 5 and $30 \mu \mathrm{m}$ thick. Occasionally we find accumulations up to $80 \mu \mathrm{m}$ in height with an area of about $1 \mathrm{~mm}^{2}$.

On these samples localized measurements and confocal topographies have been taken, as well as visu observations on the surface of the samples before and after treatment.
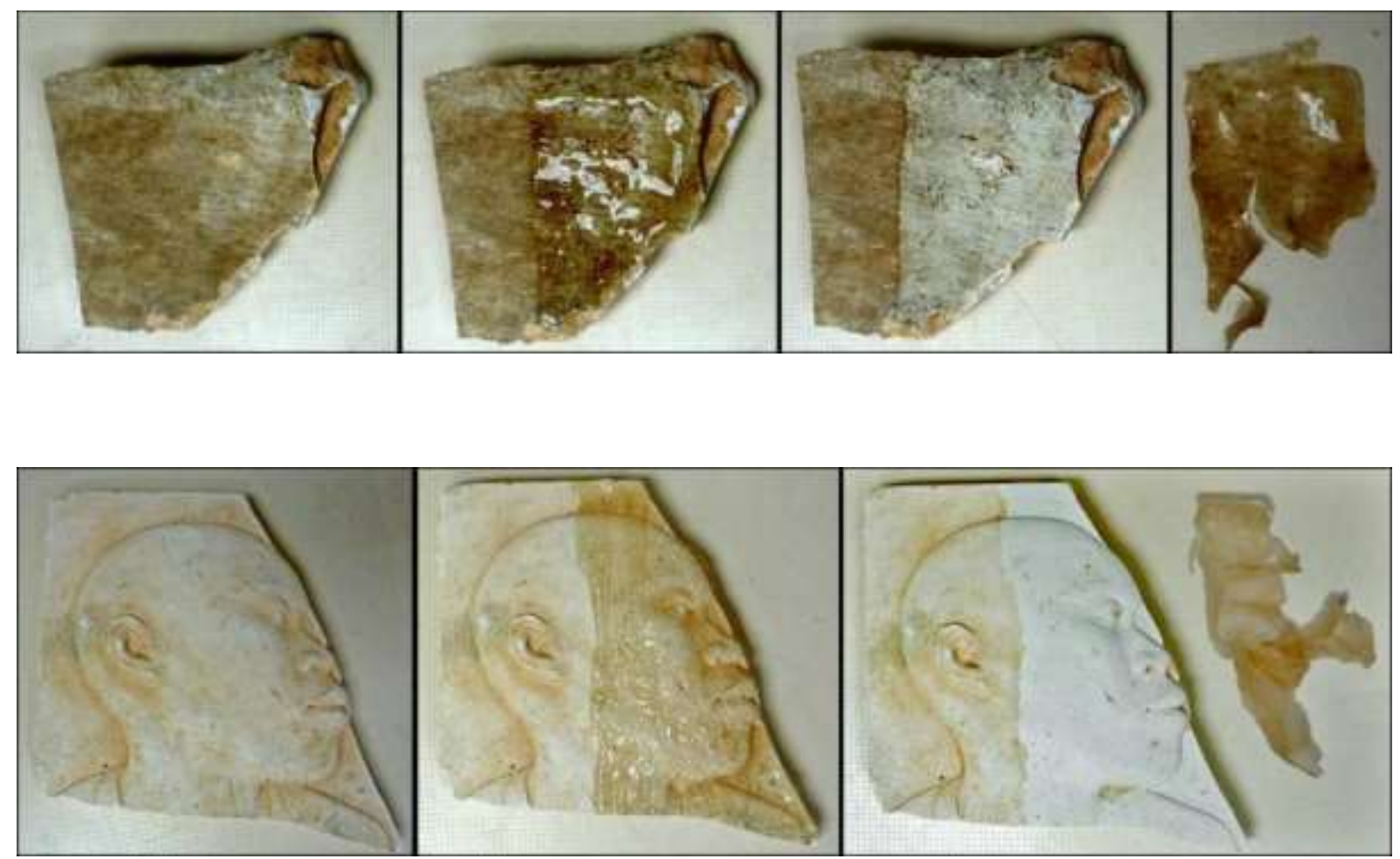

Figure IX: Upper: Application of $2 \%$ agar gel for 5 minutes. Observe the migration of dirt on the borderline between the treated and untreated areas. Lower: Application of $2 \%$ agar gel for 20 minutes. 
In all treatments applied, regardless of the duration of treatment, we have found there has been a loss of support material. In applications less than 30 minutes, we could describe these losses as acceptable. In the case of treatment with two successive applications of 2 minutes, note that the second application has removed a greater amount of support material, possibly due to softening of the surface.

From these experiences it is advisable to apply the product with substantial thickness to make its removal easier in order to reduce the amount residues when working with this type of gels. Indicate that the residues are concentrated in the recesses of the samples.

\section{Conclusions}

Concerning variations in the surface morphology of the samples, an average value of initial roughness $R a=1.325 \mu \mathrm{m}$ was calculated (coefficient of variation: $18.7 \%$ ), measured over an area of $4.4 \mathrm{~mm}^{2}$, on a total of 6 samples and prior to any treatment applied [Table II]. After the various tests conducted, we have found that 4\% treatments of longer duration, 2T (20 minutes) and 3T (totally dry), the material changes throughout the treated surface. For the 20 minutes treatment the roughness increases to $3.283 \mu \mathrm{m}$, with the appearance of a pitted surface. The 3T, totally dry, treatment causes more severe effects, generating an abrupt surface texture, with mean values of $\mathrm{Ra}=45.5 \mu \mathrm{m}$.

Table II. On the first two left columns initial roughness measurements are shown. On the two right columns treatments showing significant variations are recorded as general and localized values (in parenthesis).

\begin{tabular}{|l|l|l|l|}
\hline \multicolumn{2}{|l|}{ Initial Roughness } & Treatment & Final roughness \\
\hline Average (6 samples) & $1,33 \mu \mathrm{m}$ & $4 \% 3 \mathrm{~T}$ & $45,45 \mu \mathrm{m}(148,68 \mu \mathrm{m})$ \\
\hline Standard Deviation & $0,25 \mu \mathrm{m}$ & $4 \% 2 \mathrm{~T}$ & $3,28 \mu \mathrm{m}(7,03 \mu \mathrm{m})$ \\
\hline Coeficient of Variation & $18,70 \%$ & $2 \% 3 \mathrm{~T}$ & $1,12 \mu \mathrm{m}(11,48 \mu \mathrm{m})$ \\
\hline
\end{tabular}

The modifications discussed above affect the entire sample surface. In both cases, 4\% 2T and 4\% $3 T$, localized variations in roughness occur (greater than the overall value), as well as in the $2 \% 3 T$ (totally dry) treatment, with $\mathrm{Ra}=11.5 \mu \mathrm{m}$, although their general values stay in the initial range. For the $4 \% 2 \mathrm{~T}$ (20 minutes) application time, $\mathrm{Ra}=7 \mu \mathrm{m}$ values are reached. When using $4 \%$ and $3 \mathrm{~T}$, totally dry, treatments Ra goes up to $148.7 \mu \mathrm{m}$ [Table II]. When evaluating the rest of the treatments the roughness values remain within the range of values established initially. In all cases the areas where roughness changes have occurred are those of plaster material loss.

Experimental results show that treatments 4\% 3T and 4\% 2T reduce the permeability of the material ( $12 \%$ in the first one, and approximately $8 \%$ in the second). In the case of treatments $4 \%$ $2 \mathrm{~T}$ and $3 \mathrm{~T}$ the trend in all samples is to reduce their permeability (all the samples tested gave lower 
values of permeability after treatment) [Table III]. As a hypothesis, this decrease is considered to be possibly caused by the increased in surface roughness which results in larger surface area with a consequent increase of phenomena of surface adsorption of water vapor molecules, slowing down their ascent to the atmosphere.

In all other cases, although the average value indicates a positive direction, there is not a clear trend for these treatments, since in all of them some of the samples show a decrease in permeability. Moreover, in these cases, it must be said the variations between the permeability values obtained before and after each treatment are less than $2 \%$ (i.e. very small. $5 \%$ is the maximum percentage variation that is allowed between two consecutive weightings when calculating the value of water vapor permeability of a material). Therefore, due to the small variation in the results, we can say that the changes in permeability caused by these treatments are not significant.

Regarding the loss of material [Table IV] only the applications of longer duration (totally dry) and with higher product concentration (4\%) cause a significant loss in the sample weight after treatment. It should be emphasized that none of the material losses are homogeneous across the surface of the sample. As the reference average value, it was calculated that the loss of material per unit area which amounts to $4.74 \mathrm{mg} / \mathrm{cm}^{2}$. In treatments with $2 \%$ total dry, a small localized loss of material has occurred $\left(0,08 \mathrm{mgr} / \mathrm{cm}^{2}\right)$.

Table III. Variations of the water vapor permeability for each treatment.

\begin{tabular}{|l|l|l|l|}
\hline Permeability & Befote & After & Variation \\
\hline Treatment & $(\mathrm{gr} / \mathrm{m} \times 24 \mathrm{~h})$ & $(\mathrm{gr} / \mathrm{m} \times 24 \mathrm{~h})$ & $(\%)$ \\
\hline $4 \% 3 \mathrm{~T}$ & 2,058 & 1,810 & $-12,07$ \\
\hline $4 \% 2 \mathrm{~T}$ & 1,919 & 1,767 & $-7,91$ \\
\hline $4 \% 1 \mathrm{~T}$ & 1,818 & 1,838 & 1,13 \\
\hline $2 \% 3 \mathrm{~T}$ & 1,668 & 1,684 & 0,96 \\
\hline $2 \% 2 \mathrm{~T}$ & 1,801 & 1,832 & 1,73 \\
\hline $2 \% 1 \mathrm{~T}$ & 1,683 & 1,713 & 1,79 \\
\hline
\end{tabular}


Table IV. Loss of material produced by each treatment and agar remains after each treatment (\% of the surface covered).

\begin{tabular}{|l|l|l|}
\hline Treatment & Weight loss $\left(\mathrm{mg} / \mathrm{cm}^{2}\right)$ & Residues (\% surface) \\
\hline $4 \% 3 T$ & 4,74 & 4 \\
\hline $4 \% 2 \mathrm{~T}$ & $<0,1$ & $2-4$ \\
\hline $4 \% 1 \mathrm{~T}$ & $<0,1$ & $0-2$ \\
\hline $2 \% 3 \mathrm{~T}$ & $<0,1$ & $4-6$ \\
\hline $2 \% 2 \mathrm{~T}$ & $<0,01$ & $0-4$ \\
\hline $2 \% 1 \mathrm{~T}$ & No & No \\
\hline
\end{tabular}

Weight loss measurements cannot be altered by the possible gain of weight due to the presence of agar gel residues. This possibility has been dismissed because of the low density of the product, its scarce presence in all cases, and the film thickness (only about 10 $\mu \mathrm{m}$ ).

The risk linked to the presence of traces of agar on the samples, has been stated through the agar films removed that were wrapped still moist with filter paper and stored in airtight plastic bags away from light. After 30 days, when they were unwrapped for study, mold had developed.

Observations with ultraviolet light and by visual analysis under $x 40$ magnification show that there are no residues in the pores of the material and the existing ones are in the form of films on the perimeter zones [table IV], especially at the lateral edges of the samples. More residues remain with longer times of application and the thinness of the gel layer applied.

Concerning the tests on real objects, it is interesting to apply the gels in very thick layers, which will greatly facilitate their removal and help prevent leaving any residues on the surface even with short times of application.

As a summary, based on the results of the study, could be considered safe and effective treatments on plaster objects:

- The $2 \%$ agar gel concentrations with times of application between 2-30 minutes

- $4 \%$ concentrations with application times of less than 5 minutes. 
In these treatments it has been proven:

- There is no removal of original material,

- The surface roughness does not change

- Vapor permeability is almost constant.

Not recommended treatments regarding damage threshold:

- Both concentrations leaving the agar gel to dry completely

- $4 \%$ application concentration over 15 min.

These treatments:

- Promote material removal

- Increase of surface roughness

- Decreasing its permeability to water vapor (for the $4 \%$ concentration)

And also we would like to state that:

- The agar-gel cleaning technique leaves no residues included in the pores.

- Application of thick films to minimize product residues is recommended.

- The presence of traces of agar is an ideal substrate for biological colonization.

- Too hot applications promote border lines.

- Like in any other cleaning technique it is better to make two consecutive short applications, rather than one longer one (ie. two 10 minutes applications rather that one of 20 minutes). It is recommended to leave enough time between applications to allow the support to dry completely.

\section{Notes}

[1] Cremonesi, P., et al. Use of Agarose and Agar for preparing "Rigid Gels" Cuaderno n. 4. CESMAR 7. II Prato. Saonara, PD, 2007. Cremonesi, P., et al. Use of Rigid Agar Gels for Cleaning plaster objects. Cuaderno n. 6. CESMAR 7. Il Prato. Saonara, PD, 2008.

[2] ALAMO. Ctra. De Fuencemillán s/n. 19292 Espinosa de Henares. Guadalajara.

\section{References}

CREMONESI, P., et al (2007). Use of Agarose and Agar for preparing "Rigid Gels" Cuaderno n. 4. CESMAR 7. Saonara: Il Prato.

CREMONESI, P., et al. (2008). Use of Rigid Agar Gels for Cleaning plaster objects. Cuaderno n. 6. CESMAR 7. Saonara: Il Prato.

ESBERT, R.M., DÍAZ-PACHE, F. (1993). Influencia de las características petrofisicas en la penetración de consolidantes en rocas monumentales porosas, en Materiales de Construcción, Vol. 230. Barcelona: Colegio de Aparejadores y arquitectos Técnicos de Barcelona.

GISBERT AGUILAR, J. ed. (2002). Caracterización y Restauración de Materiales Pétreos en Arquitectura, Escultura y Arqueología. Rocas, morteros y ladrillos. Caracterización y Patologías. Tomo I. Zaragoza: Universidad de Zaragoza.

GÓMEZ DE TERREROS, M.G., ALCALDE, M. (2000). Metodología de estudio de la alteración y conservación de la piedra monumental. Sevilla: Universidad de Sevilla. Instituto Universitario de Ciencias de la Construcción. 
RUBIO, D., RAMÓN, F. (2006). El Material de Yeso: comportamiento y conservación. Cuadernos de Restauración, número 6. Sevilla: Colegio Oficial de Doctores y Licenciados en Bellas Artes.

TORTAJADA HERNANDO, S. (2011). "El gel de agar como método de limpieza para escultura". Revista Pátina no 16. Madrid: Escuela Superior de Conservación y Restauración de Bienes Culturales de Madrid.

V.AA. (1990). Training Manual on Gracilaria culture and seaweed processing in China. Regional seatarming development and demonstration Project. Project Reports No. 6. FAO, Fisheries and Aquaculture Department, AB730/E.

YAVUZ, H., OZKAHRAMAN, T., DEMIRDAG, S. Polishing experiments on surface quality of building stone tiles. Construction and Building Materials, 25 (2011).

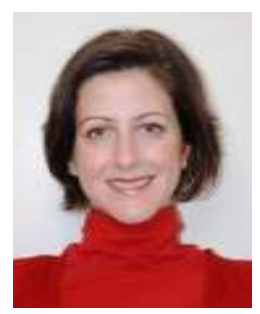

\section{Sonia Tortajada Hernando}

sonia.tortajada@museodelprado.es

Sonia Tortajada es restauradora de escultura en el Museo Nacional del Prado de Madrid, España. Es licenciada en Bellas Artes con la especialidad de restauración de escultura y D.E.A. en el programa de doctorado "conservación y restauración del patrimonio artístico" por la Universidad Complutense de Madrid, y diplomada en conservación-restauración con la especialidad de pintura por la Escuela Superior de Conservación y Restauración de Madrid. Después de varios años trabajando en el sector privado y en diferentes instituciones públicas, en 2004 entró a formar parte del departamento de restauración del Museo del Prado como restauradora de escultura, pasando a la plantilla con carácter permanente en 2008. Desarrolla su actividad profesional en obras escultóricas realizadas en piedra, escayola, barro y madera policromada, principalmente.

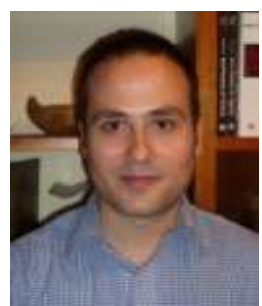

Manuel María Blanco Domínguez

rutiloblanco@gmail.com

Manuel María Blanco Domínguez, Doctor en Ciencias Geológicas por la Universidad de Zaragoza, Gemólogo FEEG (Federation for European Education in Gemmology), Técnico Superior en Artes Aplicadas de la Escultura (Escuela de Artes de Zaragoza). Ha trabajado en temas relacionados con el Patrimonio Cultural en el Instituto de Ciencia de Materiales de Aragón (CSIC-Universidad de Zaragoza), y en el Equipo de Investigación Universitario Arbotante (Universidad de Zaragoza;). Es socio fundador de la empresa spin-off Geoartec, S.L., y actualmente trabaja en el IPCE como técnico del Laboratorio de Análisis de Materiales.

Artículo enviado el 31/01/2013

Artículo aceptado el 23/04/2013 


\title{
Reformulando el museo en el contexto actual de crisis
}

\author{
Susana Solís Zara
}

Resumen: El presente artículo -de opinión personal- atiende a una crítica y análisis del rol del museo de arte contemporáneo en un contexto de crisis económica y de reconfiguración. Donde hemos pasado, a partir el inicio del postmodernismo, del fenómeno "efecto museo" y proliferación memorística -acrecentada en pleno boom económico- a nuevos tiempos de incertidumbre donde muchas instituciones museísticas de nuestro país ven afectadas sus colecciones por los recortes y ajustes presupuestarios de las diferentes Administraciones Públicas (AAPP), aumentando de esta manera el peligro de la defensa del programa y la disminución de la actividad de estos espacios expositivos que, asimismo, sufren modificaciones constantes, que necesitan adaptarse a los nuevos tiempos y a las propuestas emergentes de los artistas.

Contribuiremos - a modo de reflexión- a la discusión introduciendo ciertas cuestiones sobre el tema, cómo el impacto de la actual crisis financiera y recesión económica pone en peligro tanto la supervivencia de muchos centros culturales como la divulgación, educación e investigación de nuestro patrimonio artístico y cultural. Pues aunque no es nuestro fin aportar en este trabajo datos estadísticos ni cuantitativos, si tenemos en cuenta el tipo de titularidad, España cuenta actualmente con más de 1.550 museos y colecciones museográficas, de los cuales el $67,5 \%$ son museos públicos, un $30,4 \%$ son privados y un $2^{\prime} 1 \%$ son de titularidad mixta'.

Palabras claves: museos; crisis; patrimonio artístico y cultural; arquitectura museística; visitantes; contenido y continente; teoría y crítica institucional; turismo cultural.

\section{Reformulando o museu no contexto actual de crise}

Resumo: O presente artigo - de opinião pessoal - apresenta uma crítica e análise sobre o papel do museu de arte contemporânea num contexto de crise económica e de re-configuração. O que se passou, desde o início do post-modernismo, do fenómeno "efeito museu" e da proliferação memorística - acrescentada em pleno boom económico - até aos novos tempos de incerteza onde muitas instituições museológicas do nosso país vêm as suas colecções afectadas pelos cortes e ajustes de budget das diferentes Administrações Públicas (AAPP), aumentando, desta maneira a dificuldade na prossecução do programa e a diminuição da actividade destes espaços expositivos, que assim mesmo, sofrem modificações constantes para adaptar-se aos novos tempos e às propostas emergentes dos artistas.

Em modo de reflexão, contribuiremos para a discussão, introduzindo certas questões sobre o tema, como o impacto da crise actual financeira e a recessão económica colocam em perigo, tanto a sobrevivencia de muitos centros de divulgação, educação e investigação do nosso património artístico e cultural. Ainda que não seja nosso objectivo apresentar, neste trabalho, dados estatísticos nem quantitativos, se considerarmos o tipo de tutela, Espanha conta, actualmente com mais de 1.550 museus e colecções museológicas, dos quais $67,5 \%$ são museus públicos, $30,4 \%$ são privados e $2,1 \%$, têm uma tutela mista.

Palavras-chave: museus; crise; patrimonio artístico e cultural; arquitectura museológica; visitantes; conteúdo e continente; teoría e crítica institucional; turismo cultural.

\section{Redefining the museum in the context of present crisis}

Abstract: This article presents an analysis and critique -from a personal standpoint- of a contemporary art museum's role in a time of economic crisis and reconfiguration. What's happened since the beginning of postmodernism, the "museum era" and memory proliferation, which increased due to the economic boom, is a new era of uncertainty where many museum institutions of our country and its collections have been 
affected by cuts and the budget adjustments of different Public Administrations. This has put these institutions in danger and decreased activity in these exhibition spaces which are also suffering from constant changes. We must adapt to the new times and to the emerging artists' proposals.

By reflecting we will contribute to the discussion by introducing some questions on the subject, how the impact of the current financial crisis and economic recession endangers both the survival of many cultural centers and research of our artistic and cultural heritage. Although it's not our goal to provide statistical and quantative data, if we consider the type of ownership, Spain currently has over 1,550 museums and museum collections, of which $67.5 \%$ are public museums, $30.4 \%$ are private and $2.1 \%$ are of mixed ownership.

Key words: Museums; crisis; artistic and cultural heritage, museum architecture; visitors, content and continent, theory and institutional critique; cultural tourism.

\section{Introducción}

En el contexto de la sociedad postindustrial, la cultura y el conocimiento toman protagonismo, del mismo modo que la memoria y su recuperación se han convertido en una obsesión global. El concepto de patrimonio cultural ha crecido sin cesar en los últimos tiempos con la aparente intención de dar satisfacción tanto a una sociedad postfordista que demanda "un mayor conocimiento" como a una insistente mirada hacia el pasado. Tal y como advertía el crítico alemán Andreas Huyssen: "Uno de los fenómenos culturales y políticos más sorprendentes de los últimos años es el surgimiento de la memoria como preocupación central de la cultura y la política de las sociedades occidentales" (Huyssen 2002: 23).

Como resultado, cada vez ha sido más habitual la creación y ampliación de nuevos espacios culturales para albergar un determinado patrimonio (material e inmaterial). Incesantemente se han fundado múltiples y distintos tipos de museos, extensiones o renovaciones de antiguos edificios como centros culturales, nuevos espacios con carácter museístico y/o conmemorativos, múltiples (macro) exposiciones, nuevos proyectos artísticos y culturales de digitalización (gracias especialmente a los nuevos mecanismos de producción de imagen, a las nuevas tecnologías de la información y la comunicación -TIC-, así como a la democratización informativa de la redes mediáticas) ${ }^{2}$, y a diversos modelos museológicos y museográficos que plantean un nueva concepción de museo que poco tiene que ver con el tradicional museo-almacén.

Este "efecto museo" y proliferación memorística se ha dado desde la década de los setenta, pero se ha intensificado a partir de los años ochenta, cuando se afianzó la cultura posmoderna del entretenimiento y la industria cultural ${ }^{3}$ de la sociedad postindustrial, coincidiendo a su vez con las estrategias revisionistas de la institución artística y con un crecimiento económico. En especial con el Centro Georges Pompidou de París (1977), pionero en lo que a público masivo se refiere y el que marcará el punto final de los museos del Movimiento Moderno y de partida de la Postmodernidad, cuando se dé con mayor impulso el fenómeno de un considerado aumento de nuevos museos y centros de arte contemporáneo, tanto de nueva planta como de edificios reutilizados para tal fin. Mas en el caso de España, hasta la llegada de la democracia no se catalizarán nuevos movimientos, por tanto este fenómeno se iniciará con bastante retraso incorporándose a finales de los años ochenta, siendo el punto de partida la creación en 1986 del Centro de Arte Reina Sofía 4 .

De modo que aquellas formulaciones de nihilismo "museal" y del arte institucionalizado levantadas sobre todo en los años sesenta y setenta por parte de distintos artistas y pensadores (ceñidos al debate sobre la muerte de Dios, el Ser y el Arte $)^{5}$, paradójicamente desembocó en una progresiva 
expansión museística, cobrando el museo todo su protagonismo y su monopolio en el discurso artístico dominante y en la difusión del arte en una vitalidad nunca vista hasta ahora, al igual que la exitosa proliferación de centros artísticos, galerías de arte y (macro) exposiciones.

Este fenómeno, desde las dos últimas décadas del siglo XX y principios del siglo XXI, ha adquirido tal dimensión que merece cierta reflexión o comprensión y un deseo de interpretación que, en "nuestro" caso, parte del asombro que despertó el macroespectáculo de la museomanía arquitectónica que se ha estado rivalizando principalmente entre los museos y centros de arte contemporáneo. Además, este interés por el museo nace de una serie de preguntas que, como artista y consumidora interesada en el hecho expositivo, me hago acerca de las prácticas de exhibición dentro y fuera de los museos y en torno a los espacios de discusión sobre las prácticas artísticas e institucionales.

Si bien, la madre institucional museística una vez más se encuentra en plena crisis de identidad -en un contexto de profunda crisis económica, financiera y política-, en busca de una necesaria reformulación de su concepción desde su uso, según su finalidad, acorde a los nuevos tiempos. Del mismo modo que la exposición entendida como dispositivo de presentación artística (y uno de los elementos primordiales de la articulación discursiva del museo) por los contenidos con los que ella trabaja en el arte contemporáneo, entre otras causas, necesita de una definición puesta permanentemente en crisis para evitar que se transforme en un intocable instrumento superado (Manen 2012: 12).

\section{Objetivos, relevancia de la investigación y metodología}

El objetivo principal de este estudio abierto, es la inducción a una profunda reflexión y a un debate de múltiples interrogantes que traza la posición existente del museo postmoderno en el contexto de crisis actual, profundizando en el conocimiento de nuevos planteamientos y usos del museo a través de distintos períodos y ejemplos internacionales (muy distintos en relación con aquellas que ha ido asumiendo el museo tradicional desde sus orígenes: pasando de ser simples almacenes, contenedores de tesoros merecedores de fervor, a reivindicarles una dinámica viva, mudable y renovadora). Teniendo también en cuenta la presentación expositiva -como formato estrella- del arte contemporáneo. Esbozando cuáles son algunos de los mecanismos y relaciones de poder y control de las instituciones museísticas, donde se revisan algunas de las propuestas e ideas que plantean distintos autores desde la teoría y la crítica institucional, donde se encuentran muchas preguntas, que más que responder, me interesa plantear.

Nunca como hasta este momento había sido tan cuestionado el papel del museo como institución cultural, hasta el punto de que en numerosas ocasiones se ha hablado de una "muerte del museo", en concreto de los museos de arte contemporáneo. Pero a pesar de que el museo es una "institución en crisis" tampoco antes había despertado tanto interés como también demuestra la reciente numerosa producción bibliográfica museística -de la que haremos un gran uso en nuestra metodología de trabajo- a la vez que se ha convertido en un centro de mira de numerosos historiadores, teóricos y artistas, como paradigma de la cultura contemporánea, deslizando a la obra de arte a un segundo plano.

La relevancia de este trabajo pone también en cuestión el antecedente que originó la inquietud por el problema que se desea analizar: la posición artística del edificio-museo, pues el interés por crear un diseño espectacular ha supuesto el riesgo de que la arquitectura museística arrebate la 
importancia a las obras exhibidas. Tal y como puso de moda el Guggenheim de Bilbao, inaugurado con rotundo éxito en 1997, como paradigma de la cultura convertida en instrumento de consumo pero también de revitalización urbana y económica (Guasch y Zulaika 2007: 13; Zulaika 1997). Cuestión que, interrogada en multitud de ocasiones (especialmente en foros, conferencias y publicaciones especializadas) los diferentes y diversos aspectos de la nueva museografía, es pertinente analizar ya que está profundamente relacionado con la crisis de estas instituciones culturales.

Por otra parte, los museos se han convertido a finales del siglo pasado en uno de los principales referentes culturales, tendencia que mueve a miles de turistas todos los años, pero esta nueva situación no está exenta de una serie de problemas que trataremos también de prestarle atención y que empezaron a examinarse en el S. XX.

Si bien, no es menos cierto que a día de hoy este tipo de construcciones se ha visto aminorado por la recesión económica, puesto que una de las primeras consecuencias de la crisis en los museos tiene que ver con los proyectos de construcción y renovación, muchos proyectos importantes han sido aplazados o directamente abandonados, y otros ya construidos han sido cerrados. Este nuevo fenómeno, se presta a un significativo análisis y valoración, en el que adoptaré una metodología de trabajo de carácter reflexiva y crítica -desde una sensibilización con el asunto a partir de la observación y experiencia en la visita a estos espacios expositivos, enriquecida con el estudio de la teoría y la crítica institucional, la consulta de fuentes bibliográficas en materia museística y publicaciones de revistas especializadas, investigaciones, páginas web, prensa, etc., con la intención de aportar nuevas preguntas y respuestas a este tema vigente de existente discusión, para que este artículo teórico no constituya un punto final de este trabajo, sino una puerta abierta hacia la prolongación de este estudio u otro.

\section{Resultados y discusión}

En nuestra sociedad occidental, mediatizada y consumista, calificada por algunos de postmoderna y neobarroca, el Museo a pesar de ser una institución primordial en el ámbito cultural y patrimonial, es hoy día algo más que un espacio arquitectónico-apropiado- para la conservación y contemplación de obras que han sido socialmente consideradas como artísticas, se ha convertido con mayor asiduidad en objeto y objetivo público de deseo que ha hecho acrecentar la aparición de nuevos planteamientos y usos de éste muy distintos en relación con aquellos que ha ido asumiendo el museo tradicional desde sus orígenes.

No cabe duda que ha perdido vigor en la sutil definición y análisis del filósofo-sociólogo alemán Theodor W. Adorno, dado en la década de los sesenta, al equiparar museo con mausoleo:

"La palabra alemana museal tiene connotaciones desagradables. Describe objetos con los que el observador ya no tiene una relación vital y que están en proceso de extinción. Deben su preservación más al respeto histórico que a las necesidades del presente. Museo y mausoleo son palabras conectadas por algo más que la asociación fonética. Los museos son los sepulcros familiares de las obras de arte [...]" (Adorno 1962: 187).

Efectivamente, el museo es un lugar donde se transforma la percepción de las obras, son mucho más que refugios neutros para el arte. Sin embargo, hace ya tiempo que dejó atrás la función de dar sólo cuidado a las colecciones particulares y a programas determinados, la superación del modelo de museo como palacio, como galería o como templo, es a día de hoy una evidencia, ya no 
es esencialmente un tesoro de colecciones de objetos culturales. Inclusive numerosos son los museos que han sido creados sin una colección permanente, fenómeno que ha hecho valorizar todavía más el objeto arquitectónico-exhibido como continente y contenido- siendo la única obra de arte permanente aunque no inalterable por la crecida de ampliaciones, extensiones y remodelaciones del edificio. Pasando de un aparente contenedor neutro a un objeto artístico destacado de la exposición y, en consecuencia, transformándose estas "nuevas catedrales" de nuestro tiempo -nada exentas de espectáculo- en uno de los espacios más relevantes de promoción urbana, de peregrinación del turismo y en lugar de atracción para el consumo de masa [figura 1].

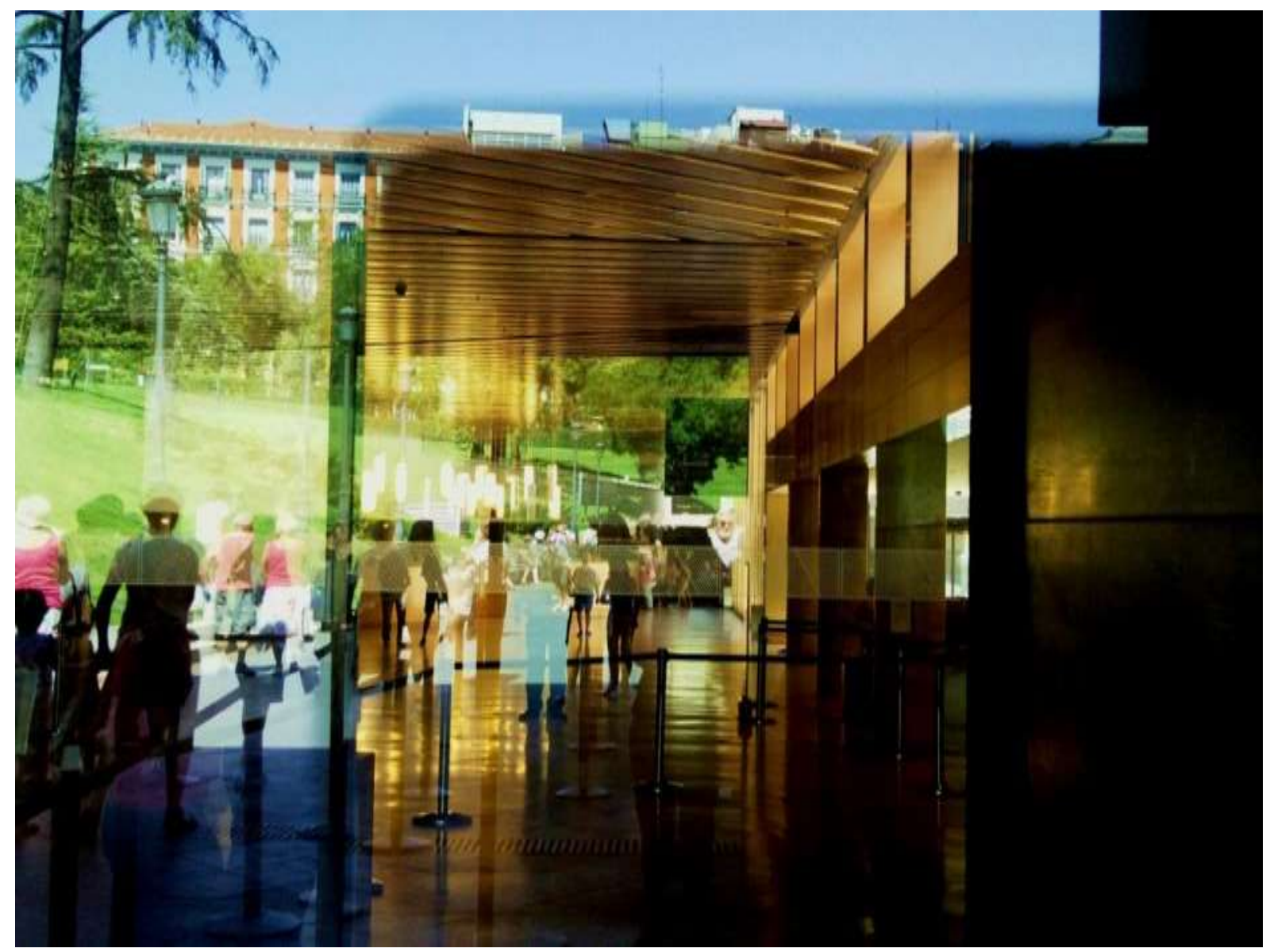

Figura 1. Imagen de visitantes en el Museo del Prado (Madrid). Detalle de la reciente ampliación del arquitecto R. Moneo (2007). OSusana Solís Zara.

Esta actual "embriaguez museística", en el que hemos pasado del modelo de museo-almacén, al museo fábrica (o laboratorio) y en los últimos años al tipo de museo seductor y espectacular, confirma que "la ciudad postmoderna tiene como emergencia a los museos como monumentos de la economía y de la movilidad social" (Amendola 2000: 183-209), precediendo a estos edificios la atracción de numerosos medios de comunicación y largas colas aglomeradas de un amplio público, mientras que el objeto-museo se ha dispuesto -como un gran centro comercial- a ser consumido debido principalmente a un gran despliegue creativo de sus arquitectos donde "el edificio [museo] debe ser tan personal en su formulación como el lienzo del pintor o el boceto de 
un dibujante", según sostiene el artista y critico Douglas Davis (Davis 1990: 16).

Si el MOMA de Nueva York (fundado en 1929 y construida su nueva sede con arquitectura moderna en 1939) constituyó un nuevo paradigma museístico en la modernidad sirviendo como modelo internacional (con su supuesta pulcritud estética e ideológica del White Cube) (O'Doherty 2011), el Guggenheim neoyorkino (1959) y principalmente la creación del Centro Pompidou de París marcarían un hito a partir del cual todo nuevo museo debía de contar con un peculiar edificio para la recepción de un público masivo. A partir de aquí fue el instante de protagonistas como el espectacular Guggenheim de Bilbao (1997) -uno de los primeros museos que Rosalind Krauss denominó "tardocapitalista"- ${ }^{6}$ y del poderoso Tate Modern londinense (2000), que a su vez serían rápidamente ensombrecidos por otros ejemplos como fue la ampliación del MOMA en 2004 o la creación de museos de contenido histórico como la extensión del Museo Judío de Berlín (2001), un museo didáctico centrado en una sola obra que es, a su vez, el propio museo, definiéndose efectivamente el contenido a través del contenedor (Montaner 2003).

En las tres últimas décadas la motivación económica y política influyó en crear estos competitivos museos como productos comerciales vinculados al modelo tardocapitalista, influidos además por las medias y por la vertiginosa competición en la que se han desarrollado las ciudades para exhibir uno de estos destacados símbolos y monumentos en la nueva escena urbana. Museos de autor que se han transformado en verdaderos iconos hedonistas de la ciudad postmoderna, buscando afianzar su propia personalidad mediante estos imanes turísticos, estableciendo de esta manera una nueva "cultura artística" y cuestionándonos si estos museos han ayudado realmente a propagar un mayor conocimiento de cultura artística en el turismo, o han incentivado simplemente el "yo estuve alli" y, por tanto, ha convergido a un "turismo cultural" perjudicial para la cultura.

Como consecuencia, el espectáculo de la arquitectura (museística) como imán de sustanciales audiencias, junto con las pautas que promueven el negocio del ocio y el turismo, pasó a convertir estos espacios culturales en parques temáticos de atracción turística. Positivo, en el sentido de que personas que nunca antes se habían acercado a un museo se aproximan ahora a él, atraídas sobre todo por el marketing de la arquitectura-icono. Por el contrario, la posición negativa es que los "museos-espéctáculo" (con firma Pritzker) han estado restándole valía al tradicional significado del museo; que es de proteger, coleccionar y exponer, ya que según los defensores del "museo tradicional" opinan que verdaderamente lo que diferencia a un museo es la relación entre varias dimensiones: como la parte formal del edificio, objetos a exponer y colección. Lo cierto es que estos "museos estrellas" han desvinculado el edificio del contenido, adquiriendo el continente todo el protagonismo como auténtica pieza artística en sí misma (Giebelhausen 2011), e incentivando al público la peregrinación al edificio el déjà vu. Frente a esta práctica contemporánea, ha estado intentando subsistir el museo "súper-funcional", el cual no tiene un gran envoltorio arquitectural pero si, en muchos casos, una atractiva política cultural.

En el contexto actual de profunda crisis económica y política en toda Europa, pero especialmente en algunos países del sur como España, ahora se observa -mejor que nunca- el sin sentido de esa vía de "espectacularización" mediática del arte de los últimos años, que ha desembocado en una redundancia del mismo y, por consiguiente, en numerosos espacios vacíos sin actividad ni continuidad alguna. Nos hemos visto envueltos, a principios del siglo XXI, en una burbuja de museos difícilmente sostenible. Viéndose afectada sobre todo en aquellos edificios museísticos de formas espectaculares realizadas por arquitectos de renombre, fuertemente criticados por su "falta o exceso de finalidad", como han sido los megacentros culturales del Centro de Niemeyer (en Aviles) y la Ciudad de la Cultura de Santiago de Compostela. 
La crisis actual del museo (de arte contemporáneo) está íntimamente ligada a esa sobresaturación a modo de "efecto Guggenheim" en la que, en tiempos de bonanza económica -época de despilfarro y malversación política y financiera- se ha visto sumergida toda comunidad y ciudad, dando paso a una nueva generación de museos construidos con un interés de revitalización urbana y especulación inmobiliaria y, por tanto, más político, turístico y económico que por incrementar proyectos artísticos y culturales de un verdadero interés, garantizado por programas de una función clara y con vista de prolongación asegurada. El carácter que les unía a la mayoría de ellos ha sido su espectacular arquitectura, diseñado por un arquitecto de prestigio, para establecer el contenedor como la imagen hegemónica del museo y no la de su contenido [figura 2].

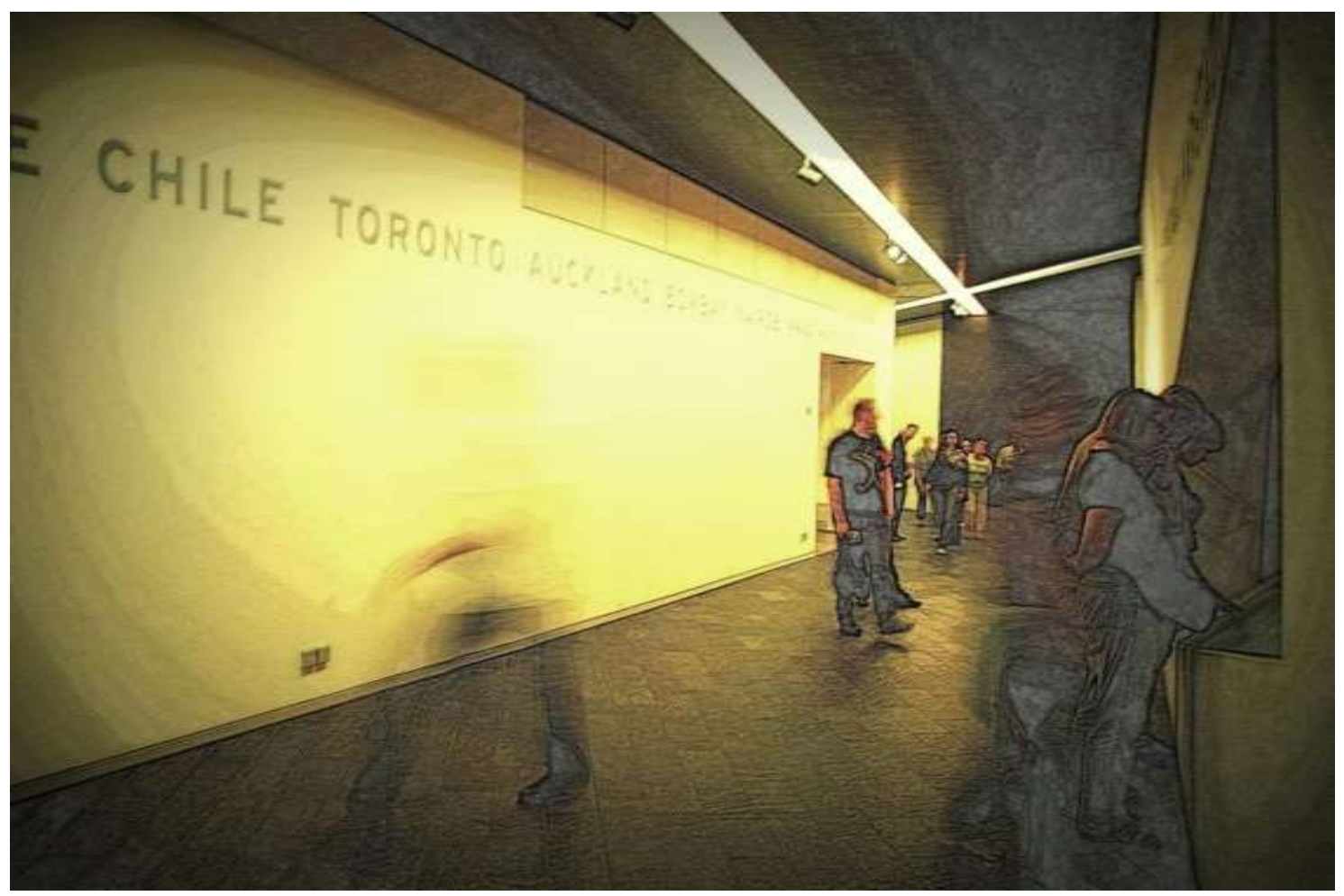

Figura 2. Detalle del Museo Judío de Berlín (2001) diseñado por el arquitecto D. Libeskind. Al igual que el Guggenheim de Bilbao, se ha convertido por su llamativa arquitectura deconstructivista en uno de los edificios más célebres internacionalmente. OSusana Solis Zara.

Definitivamente, el ciclo de crecimiento se cierra con una crisis financiera que pone en duda la supervivencia de muchos centros culturales y sacude el mapa apenas definido de un país puesto al día en estructuras y contenidos artísticos ${ }^{8}$.

En estos tiempos de incertidumbre muchas instituciones museísticas, en las cuales sus estrategias para la captación de visitantes se basan en el atractivo de las colecciones y no en operaciones de marketing (que pasan por la arquitectura icono y aquellas pautas que movilizan el negocio del ocio y el turismo), ven afectadas sus colecciones a causa de los recortes presupuestarios para la adquisición de obras de arte, situación que desafortunadamente conlleva no poder ampliar las colecciones para poder profundizar en este tipo de patrimonio que permitiría enriquecer el conocimiento de los ciudadanos y visitantes. La escasez de grandes colecciones conlleva la 
amenaza de no poder recuperar nuestra memoria histórica, como recientemente señalaba el director del Museo Nacional Centro de Arte Reina Sofía (MNCARS) Manuel Borja-Villel:

"Los huecos en una colección constituyen una especie de vacío en nuestra historia, tanto en lo que respecta a la nueva producción como en lo que se refiere al arte del pasado inmediato. Si los museos son repositorios de la memoria, nuestro país corre el riesgo de la amnesia" (Villel 2012: En línea).

A estas cuestiones se le suma el agravante de que España se ha convertido en el país de la eurozona que grava con el IVA más alto (21\%) a los productos culturales (aplicado a las artes plásticas, la música, el cine y las artes escénicas), unido a los recortes y ajustes presupuestarios de las AAPP, una medida perjudicial puesto que, sustentada en una consideración errónea de las artes como mero espectáculo, aumenta el peligro de la disminución de recursos, de actividades y de la defensa del programa de los museos y centros de arte contemporáneo, ya que nos guste o no los criterios económicos suelen ser el elemento más decisivo en la definición de la institución y lo que permite que el sistema cultural (con sus diferentes agentes: creadores, comisarios, galerías, etc.) no se debilite.

Mientras tanto, los poderes políticos y económicos han llegado a aportar unos descomunales presupuestos para la creación de estas nuevas catedrales, con la intención de recibir rentabilidad económica y, tal vez, un mayor número de votos por parte de los ciudadanos. Sin lugar a dudas la especulación en el mundo del arte no sólo se da en las obras y en los artistas, sino también en los espacios expositivos". Todo ello ha sido confirmado con el "reventón" de la reciente burbuja, con el cierre de diferentes centros de arte y otras instituciones culturales. Según lo dicho, debemos preguntarnos si el arte contemporáneo, concretamente en España, realmente ha gozado de salud democrática a lo largo de estos últimos años ${ }^{10}$.

Pero no sólo el museo de arte contemporáneo vive un momento de "crisis" de identidad y de reflexión actual, también las galerías de arte contemporáneo, las macro-exposiciones y el formato expositivo tradicional -entendido como un lugar en eterno presente, sin aparente actividad alguna a excepción del día de la inauguración- se encuentran en un estado de reformulación de su concepción y su finalidad acorde a los nuevos tiempos, en la búsqueda de nuevas definiciones y usos adaptables a las propuestas del arte emergente. (Manen 2012: 100). Por tanto, precisamos de otros modelos de presentación y comunicación expositiva para hacer partícipe al espectador frecuentemente distante y en un rol pasivo- para un consumo autónomo y comprometido de los contenidos de la misma, planteándose la incorporación de otros eventos, tiempos, ritmos y nuevos formatos expositivos que generan nuevas formas de análisis crítico del arte.

Al respecto, proyectos de gran envergadura estructural (como es la elección de edificios históricos y naves industriales rehabilitados como centros culturales o construcciones de nueva planta), planteados desde nuevas fórmulas de gestión y para la difusión de nuevas prácticas artísticas contemporáneas están ganando terreno, se presentan partiendo de estructuras híbridas donde tienen lugar a su vez distintos espacios para actividades muy variadas (artes plásticas y audiovisuales, danza, teatro, exposiciones, talleres y conferencias, salas de producción, espacios educativos, etc.), son los que proyectan el Palais de Tokyo o la Le 104 (ambos en París) -siendo el primero, el iniciado en las prácticas artísticas relacionales (Bourriaud 2008)-, u otros centros europeos de similares actitudes (o modos) como son Radialsystem (Berlín) y Zone Attive (Roma), o centros norteamericanos como el Whitney Museum o el Moma Ps1 de Nueva York, y a lo que nuestro modelo más cercano puede ser el Matadero de Madrid, la Laboral de Gijón o la Tabacalera 
de San Sebastián. Son entendidos como nuevos centros de arte contemporáneo de carácter interdisciplinar y dinámico, donde suceden constantemente eventos y actividades, que necesitan de un nuevo ritmo para su funcionamiento. Partiendo además de la idea de lugar de encuentro, de "presentación", de "producción" y "creación" (espacios de investigación artística y residencia para artistas y curadores), son nuevos formatos heterogéneos que comparten lugar en el mismo edificio, con cierta voluntad educativa y popular, e impulsando para ello lo local (e intensificando de igual modo las relaciones entre lo local y lo global) y a un visitante más activo y participativo (Manen 2012).

Esta es quizás hoy día la tipología más cercana de espacio físico para los museos y nuevos centros culturales. Si bien, muchos museos de arte contemporáneo han experimentando una transformación hacia el denominado "centro de arte", propuesto para albergar múltiples actividades más allá incluso de las meramente expositivas y didácticas: marketing, shopping, turismo y estadísticas son los puntos de maniobra para su supervivencia. Para ello se requiere de un giro radical en los contenidos de los museos que tiendan a la incorporación de otras disciplinas, pues no hay que olvidar que hoy casi todo es multi e interdisciplinar, sobre todo en la creación de las artes plásticas y visuales. Concretamente en España cada vez son más los nuevos museos que van surgiendo, en la línea del Musac de León (2005) ${ }^{11}$, que se definen como centros activos de exposiciones de arte contemporáneo y un espacio compartido en el que se despliegan un gran número de actividades multidisciplinares, teniendo como precedente y modelo más cercano el Centro de Cultura Contemporánea de Barcelona (CCCB), inaugurado en 1994 (Carrillo 2008).

Otras instituciones culturales han apostado en los últimos años por tomar como marco de actuación la propia crisis de la institución, agudizada por los actuales recortes presupuestarios en la asignación pública, como es el caso del Museo Nacional Centro de Arte Reina Sofía (MNCARS), tanto en lo referente a la remodelación de la colección del propio museo (llevada a cabo en 2009), como en los proyectos colaborativos puestos en marcha recientemente -con diversos movimientos y colectivos sociales alternativos, independientes y que están basados en la autogestión, de distintos puntos del territorio español- en los que se negocia su tradicional autoridad cultural con otros agentes no institucionalizados pero en los que se reconoce una voluntad instituyente, como es el proceso relacional -cultural y político- que se está llevando desde enero de 2011 entre el Museo Reina Sofía y la Fundación de los Comunes (Carrillo 2012).

Ahora bien, la crisis económica ha inducido a que muchas de estas instituciones artísticas organicen menos exposiciones, fomentando, en consecuencia, las exposiciones de larga duración. Problemática que, por un lado, conlleva una menor demanda de trabajo de profesionales $y$, por otra parte, plantea qué está legitimando la institución que la presenta, ¿tal vez la arquitectura del museo y su arquitecto (como artista) o bien el comisario que ha llevado a cabo la misma? Las mega-exposiciones están en el punto de mira crítico, ya que conviene más desarrollar exposiciones pequeñas de un mes de duración que promuevan también a artistas locales, teniendo en cuenta la identidad de cada espacio, que aquellas macro-exposiciones, como son las bienales planteadas desde la idea de "continente"12.

En definitiva, las nuevas instituciones artísticas han de impulsar espacios de carácter dinámico, transdisciplinar y activo, enfocados a la producción, investigación, formación, gestión y difusión de la creación artística contemporánea. Lo que conlleva todo ello un distanciamiento de la pulcritud del White Cube y una nueva definición de lo institucional [figura 3]. 


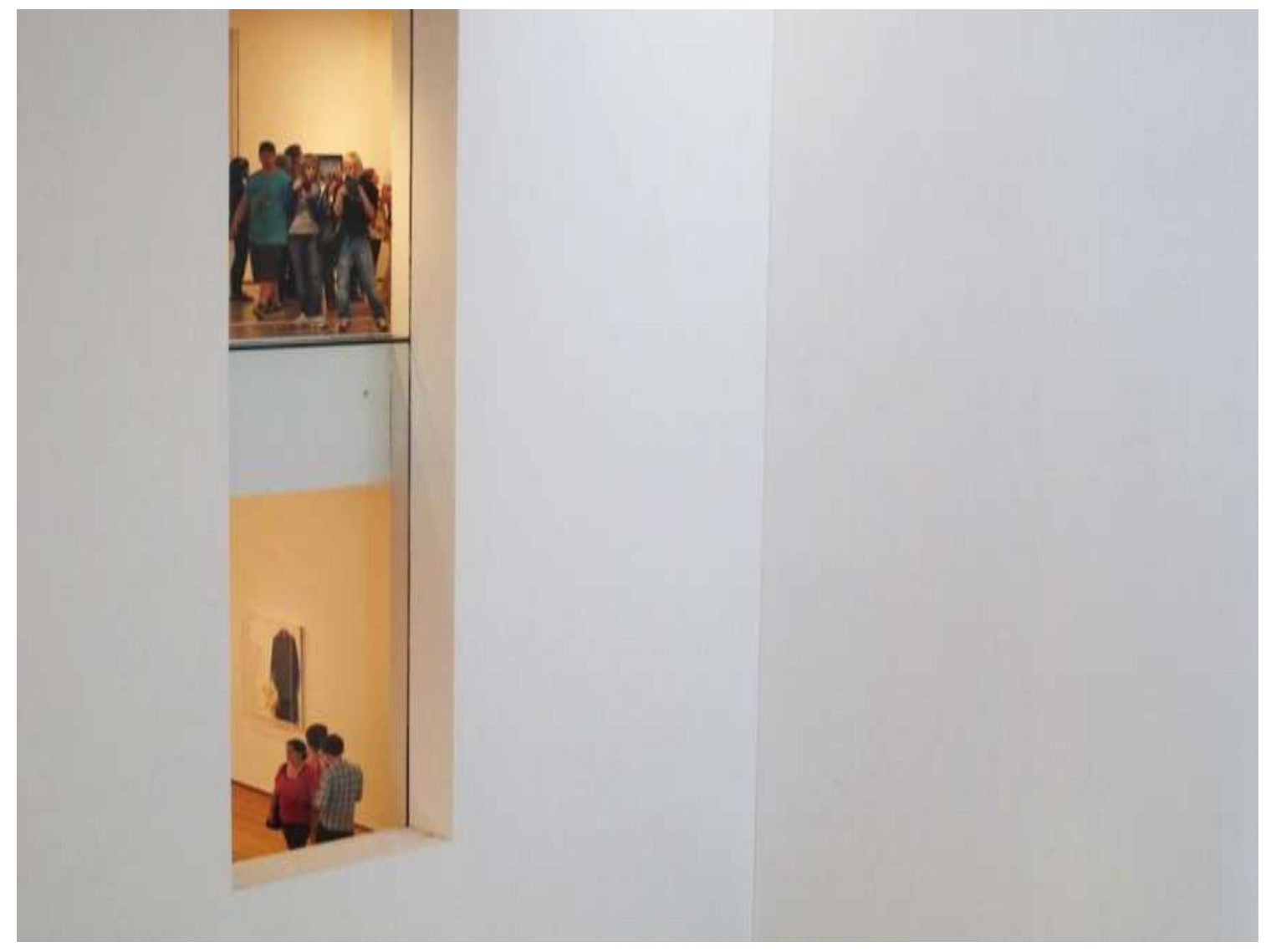

Figura 3. Detalle de la estética White Cube del Museo de Arte Moderno (MOMA) de Nueva York. OSusana Solís Zara.

En esta transformación una figura destacada que ha conllevado la misma ha sido el comisario (curador o curator) como mediador cultural entre las instituciones, el público y el artista. Curiosamente, al igual que comenzaba a cobrar un gran protagonismo los "museos de firma", la figura del comisario iniciaba también su próspera e influyente andadura a partir de los años setenta, reivindicando al arte conceptual y a los intentos de ruptura con los formatos tradicionales y con el desarrollo de un mercado de arte que diera cobijo a las nuevas prácticas artísticas y curatoriales (Guasch 2009). Principalmente gracias a los avances que realizó Harald Szeemann en el año 1969 con la exposición When Attitudes Become Form ("Cuando las actitudes devienen forma") y en 1972 en la Documenta $V$ de Kassel ${ }^{13}$. Ambas exposiciones lograron establecerse como paradigmas de una nueva forma de entender las exposiciones y la figura del comisario, pasando desde entonces por ciclos que define Beatriz Espejo: "De nacimiento en los 70, de gloria en los 80, de boom en los 90, de sobresaturación en los 2000 y, ahora mismo, de replanteamiento" (Espejo 2012: En línea).

Cabe por tanto también cuestionarse si tras la apariencia transgresora de ciertas prácticas curatoriales -frente al criterio taxonómico del museo- se esconde una estrategia de poder que convierte al comisario en autor, en el nuevo "legitimador de modas" y, en consecuencia, creador de cánones que son al fin y al cabo tan parciales y subjetivos como aquellos a los que tratan suplantar, pues sin lugar a dudas el comisario de arte contemporáneo es a día de hoy la figura clave que construye los recorridos y discursos en las instituciones artísticas. (Meijers 1996). 
Ante ello se sigue haciendo necesaria la crítica al discurso oficial de las instituciones y sus jerarquías. La figura del comisario requeriría de una investigación exhaustiva sobre su papel, función y los destacados dispositivos expositivos (o displays) que en muchas ocasiones han cobrado mayor atención que el propio discurso artístico de las obras expuestas (Badia 2011. En línea). Es decir, aún falta una verdadera investigación sobre la importancia de su rol como agente imprescindible en la dinamización y visibilización de los nuevos movimientos artísticos, como en su disposición de funcionamiento y si efectivamente es un intermediario necesario -principalmente en su rol de crítico- para el conocimiento del arte, o simplemente una manera más, al igual que la genialidad de los arquitectos, de seguir alimentando el poder y el control del sistema institucional, eclipsando del mismo modo que la espectacularidad arquitectónica y mediática la atención por otras cuestiones.

En este sentido, es difícil ver si realmente ha habido un cambio en el concepto de museo o sólo es una cuestión retórica del discurso de poder simbólico, político y económico, pues la constante evolución de los museos, unido al triunfo proliferante de los destacados displays de comisariado, enreda aún más la enmarañada madeja del concepto y la situación actual de éstos espacios institucionales. No obstante, esperemos que los museos y nuevos centros permitan activar las prácticas creativas actuales en espacios y contextos apropiados para tal fin, integrando espacios educativos, de investigación y creación, respondiendo a mantener un dinamismo en las actividades, con una oferta de programa continúo y estable, ya que son los contenidos los que deben prevalecer por encima del continente.

\section{Conclusiones}

Concluyendo, la crisis económica obliga favorecer una reconfiguración de las instituciones culturales, pero es difícil ver aún cuál será la repercusión de esta crisis en los museos y cómo enfocarán el futuro. Si bien hemos esbozado, entre otras cuestiones, cómo el impacto de la crisis influye en la construcción, renovación y cierre de muchas instituciones; en la financiación de los museos; en la adquisición de nuevas obras para las colecciones así como en el desarrollo de exposiciones temporales. En el caso de la producción de exposiciones itinerantes, como se necesita invertir grandes presupuestos, los museos cada vez más suelen retrasar la realización de nuevas exposiciones temporales y a mantener las exposiciones permanentes, cuestión que, a mi entender, puede dar pie a una nueva relevancia del concepto museo-almacén, a pesar de que las investigaciones muestran que la multiplicación de exposiciones temporales favorece el aumento de la frecuentación de los museos, situación que indudablemente también beneficia económicamente a dichas instituciones.

Pero, del mismo modo que no podemos dar por sentado como resultado de calidad el éxito expansivo de museos y centros de arte contemporáneo de manera masiva e inminente en continuo crecimiento -aunque a día de hoy en menor grado desde que estalló la crisis-, tampoco podemos dejarnos llevar por las cifras abrumadoras de audiencia que reciben las grandes instituciones artísticas y que en algunos casos, a pesar de la recesión económica, continúan incrementándose ${ }^{14}$. Es necesario buscar nuevos mecanismos que no sean cuantificables para saber cuál es el impacto o el nivel de conocimiento adquirido por el público tras la visita a un museo o una exposición. El éxito no sólo puede medirse cuantitativamente, porque cantidad no es sinónimo de calidad y equidad, ya que "atraer masificación de visitantes no es el camino para democratizar la cultura", como afirmaba recientemente Jesús Carrillo (investigador de crítica institucional y jefe de Programas Culturales del Museo Nacional Centro de Arte Reina Sofía) ${ }^{15}$. 
Pues a pesar de que los museos se han convertido en potentes industrias capaces de generar una enorme cantidad de dinero para las economías locales (hostelería, restauración, transporte, etc.) y, por tanto, desde el punto de vista económico es beneficiosa para una ciudad, lo cierto es que no podemos dar por concluyente que un museo goce de buena salud por las cuantiosas visitas que recibe al año. Ya que este nuevo rol del museo, como eficaz motor de gran atractivo turístico y desarrollo económico, puede distorsionar la misión y el discurso de las instituciones con respecto a una de sus principales tareas: el museo al servicio de la sociedad y su desarrollo como agente educativo y cultural, según el Consejo Internacional de Museos (ICOM), puesto que "Io que justifica en última instancia la institución de los museos es su compromiso permanente con la educación. La educación es consubstancial a la institución llamada museo" (Ballart 2007: 215-216).

De modo que, con respecto a la subida del IVA cultural al 21\%, el Gobierno Central español debería reflexionar para reformar sus políticas culturales y de austeridad aplicadas al ámbito de la cultura y las artes, porque al fin y al cabo esta subida no sólo afecta al sistema cultural y al desarrollo de la creación, sino también al saber, a la educación, a la innovación y la investigación científica. En tiempos de crisis actuales, la cultura y las artes son de máxima prioridad para la autocrítica y autoestima de una sociedad, la precisamos no sólo porque contribuye a aportar conocimiento, sabiduría y entretenimiento, sino porque además la industria cultural es un gran dispositivo económico del país y si aumentan drásticamente los precios, sin lugar a dudas el consumo de cultura descenderá, entre otras consecuencias dañinas para el futuro del país, puesto que la cultura ayuda también a incrementar por ejemplo la actividad económica en otros sectores (como el turístico y el comercial).

Pero no podemos atender exclusivamente a la espectacularidad y el entretenimiento que conlleva el mercado de las industrias culturales como un medio más de riqueza económica, cayendo en un puro consumo, puesto que ello lleva a una espectacularización y banalización del arte y la cultura, a deteriorar el pensamiento y a una ausencia de reflexión crítica que desembocaría en una sociedad desdichada y anquilosada. El museo contemporáneo ha de transmitir otros valores -sobre todo en plena era vacía según G. Lipovestky- no sólo estéticos, culturales y comerciales, sino fundamentalmente valores éticos y morales ${ }^{16}$ que son necesarios en tiempos de crisis actuales (tanto económica, política y social -que evidencian la falla del sistema- como de pérdida de valores personales y sociales). Precisamos de otras iniciativas artísticas que se ajusten principalmente en el impulso de proyectos más que en los edificios, promoviendo la creación local y el modo en que ésta se expresa, generando actividades paralelas a los proyectos expositivos, para concebir momentos de creación de discurso presente e impulsar las relaciones sociales en contacto cercano y directo, siendo para ello esencial enfocarse exclusivamente en los contenidos (Bourriaud 2008: 6-8).

Además, pese a que el enorme aumento de numerosas exposiciones y otros acontecimientos artísticos que se organizan a diario (dentro y fuera de estos espacios) ha sido un factor destacado para atraer un mayor flujo de personas, es necesario fomentar nuevas iniciativas de educación, ya que esta es clave en la emancipación del individuo y en la creación de un espíritu crítico. Es preciso potenciar tanto un mayor número de actividades artísticas y pedagógicas (performances, workshops, seminarios, cursos, congresos, jornadas, ciclos de vídeo y de cine, visitas guiadas, etc.), en museos y centros de arte contemporáneo, como el desarrollo de la creatividad en los centros educativos: formar a creadores y no solamente a meros consumidores, para adquirir no sólo competencias artísticas y culturales, sino también lingüísticas, sociales y ciudadanas, así como de autonomía e iniciativa personal, entre otras [figura 4]. 
Para ello sería conveniente favorecer la creación de centros culturales y artísticos a modo de museos-escuelas de referencia para la educación artística, especialmente en zonas desfavorecidas ${ }^{17}$, dejando de alimentar el obsoleto concepto de museos-refugios elitistas que son al fin y al cabo asequibles para un público minoritario.

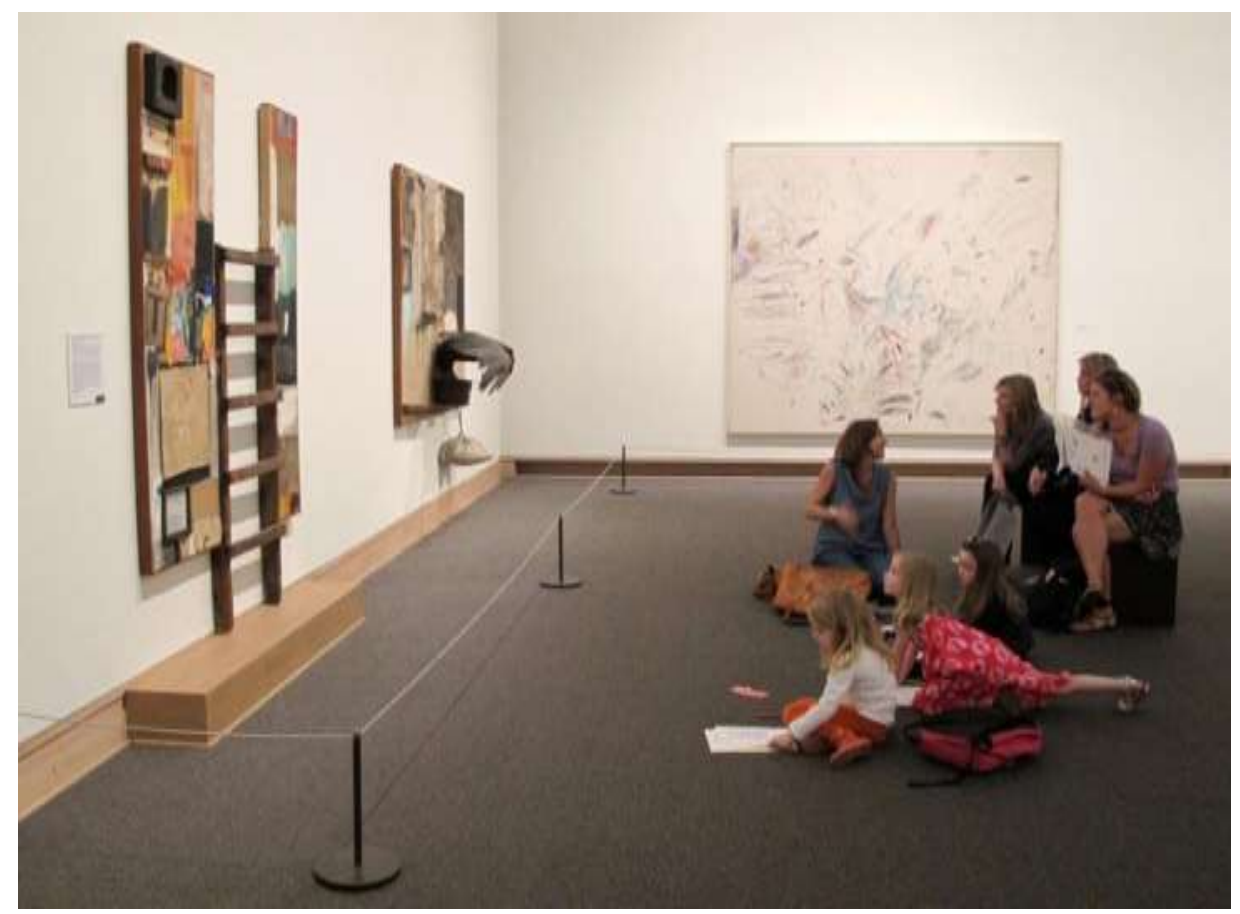

Figura 4. Museo de Arte Moderno (MOMA) de N.Y. CSusana Solís Zara.

Con la intención también de dar respuesta a nuevos retos educativos, estos y otros asuntos relacionados con la institución museística han de debatirse en la enseñanza, ya que están íntimamente ligados con la educación y la cultura, con el aprendizaje artístico-cultural y, por tanto, con la democratización del arte y la cultura. En definitiva, asuntos de poder que están vinculados con lo que se evidencia como conocimiento (o no), con las escalas de jerarquización, influidas de ciertos valores de una clase dominante. ${ }^{18}$ La Universidad especialmente, debe estudiar y analizar esta transformación y evolución, en la que también tiene parte de responsabilidad, con su inestimable y valiosa aportación. Pues si en muchas instituciones culturales se ve cada vez más la necesidad de llevar a cabo programas paralelos a las exposiciones, con actividades educativas, con el fin de facilitar el acceso a la cultura, atender a la diversidad y hacer más partícipe y activo a un amplio y variado público, y si efectivamente algunas de las funciones principales de los museos es precisamente educar, comunicar y ser un productor de sentidos así como un portador visual de la historia (de acuerdo a una mirada y un discurso no neutral), el sistema educativo y la Universidad principalmente tienen ante todas estas cuestiones un importante reto por delante y su contribución es sumamente substancial y necesaria, ya que la educación es además el mejor medio para salvarnos de la crisis actual.

Con dicho fin, la Universidad ha de servir como un foco destacado para la teoría y la crítica institucional (King y Marstine 2006), aproximándonos a la Historia del arte contemporáneo y a la cultura visual de las últimas décadas, debido a los cambios producidos tanto en función del propio 
concepto de arte, como en función de la naturaleza de la institución que lo alberga, lo difunde y lo discute. No nos podemos abstraer de lo que ocurre a nuestro alrededor. El organismo universitario debe participar de manera activa en esta transformación permanente, pues actualmente la existencia del museo en crisis -entendido como plataforma de crítica- se define como un "lugar de encuentro y de debate crítico" (Carrillo 2012), abogando asimismo por la interacción entre culturas, así como entre distintas plataformas artísticas y educativas.

Por consiguiente, la institución museística ha estado y deberá estar en permanente "crisis", ${ }^{19}$ para seguir siendo cuestionada, analizada y sometida a profundas observaciones en sus aspectos básicos (como puede ser su carácter dogmático, de institución de poder y su manipulación en el modo de organizar el conocimiento)(Guasch 2011: 42), con el fin de solventar ciertos malestares para una adaptación favorable a su época, porque al igual que la actividad artística constituye un ejercicio donde las formas, las modalidades y las funciones evolucionan según las épocas y los contextos sociales, y efectivamente no tiene un carácter inmutable, el museo como institución cultural y servicio público ha de estar en constante transformación para adaptarse a las necesidades de los nuevos tiempos, sobre todo según nuestra actual sociedad, tan cambiante y efímera.

No cabe duda que la crisis afecta negativamente al funcionamiento de los museos, pero debemos ser optimistas porque también estimula nuevos desafíos, ya que obliga a replantearse su concepción, su cometido, el desarrollo de sus colecciones y sus estrategias de comunicación. En este sentido, las nuevas tecnologías permitirán a los museos la creación de nuevas formas de conocimiento y de difusión de sus colecciones y archivos, programas expositivos y educativos, además de nuevas formas de trabajo y de relaciones socioculturales mediante la participación en redes sociales, plataformas online y otros nuevos canales que, asimismo, están marcando un cambio de paradigma en la producción, distribución y recepción de la experiencia estética. Por contra no suplirá la asistencia de personas al museo y, en definitiva, las relaciones sociales en un entorno físico "real". Cabe efectivamente cuestionarnos, cuál será el futuro que nos deparará el museo, sobre todo desde el desarrollo de las nuevas tecnologías y plataformas (digitales), ya que es una máquina del tiempo que como identidad cultural y colectiva se ve obligada a una mutación e innovación constante.

\section{NOTAS}

[1] Otro dato a destacar -según la encuesta de 2010 de museos y colecciones museográficas del Ministerio de Educación, Cultura y Deporte- es el número de profesionales que trabajan en estas instituciones: 14.784. De los cuales, el $91 \%$ trabajan en museos de titularidad pública. Datos que, a su vez, han sido publicados recientemente en el Diario El Confidencial. Sobre ello véase: "Los profesionales de los museos dan la voz de alarma sobre su precariedad" (E/Confidencial, 26-03-13).

[2] Hoy más que nunca se ha hecho realidad el sueño de André Malraux expresado en su ensayo, sobre un museo de confrontación y de metamorfosis, El Museo Imaginario (1947), el cual se nutre de la "reproducción en serie" de una obra de arte en todas sus formas y formatos. Respecto a una reciente interpretación de ello véase: Rosalind Krauss "Postmodernism's Museum Without Walls" (2005: 241245).

[3] La denominación de "industria cultural" es considerado uno de los primeros conceptos de la teoría crítica sobre la cultura de masas, acuñado en 1944 por los filósofos alemanes Theodor Adorno y Max Horkheimer que lo inscriben en una profunda reflexión sobre el devenir de la cultura en su Dialéctica de la llustración. Fragmentos filosóficos (Adorno y Horkheimer 1944). 
[4] En España existen tres precedentes de centros de arte contemporáneo, según advierte el Historiador y Conservador de Museos José Ramón López Rodríguez en su libro Historia de los museos de Andalucía 1500-2000 (2010: 538): el Centro de Arte Reina Sofía de Madrid, inaugurado en su primera fase en 1986 acogiendo muestras temporales, y que en 1988 pasaría a convertirse en el Museo Nacional Centro de Arte Reina Sofía (MNCARS) tras asumir la colección del Museo de Arte Contemporáneo de Madrid; El Instituto Valenciano de Arte Moderno (IVAM), inaugurado en 1989; y el tercero, el Centro Atlántico de Arte Moderno (CAAM), inaugurado en el mismo año que el IVAM.

[5] El inicio de la segunda mitad del siglo XX es también el momento en el cual el sistema del arte empieza a tambalearse bajo el signo de "la muerte del autor", proclamada por el filósofo y semiólogo francés Roland Barthes en su famoso ensayo -de corte estructuralista- "La muerte del autor" (1968). Además, según los cambios sociales y culturales que se avecinaban en la década de los 60 y 70, una serie de teóricos, intelectuales y artistas ponían en cuestión la validez y los valores del museo moderno (en relación a la "pérdida de la autoría" (institucional) proclamada por Barthes).

Asimismo, una de las críticas más mortíferas será la de Theodor W. Adorno dada en 1962, teniendo en cuenta el pensador alemán las teorías formuladas por Paul Valéry respecto al "museocontenedor", en el sentido de restarle vida propia a las obras exhibidas tales espacios neutros de la modernidad, constituyendo en definitiva una estrategia de poder relacionada con la supremacía del capitalismo y que, por tanto, neutraliza la propia cultura, razón demás por la que Adorno terminó considerando los "museos como mausoleos" y "sepulcros para las obras de arte", en su publicación "Valéry Proust Museum" (1962: 187). Si bien, uno de los autores que mejor narró aquel inminente cuestionamiento, en torno a la supremacía estética e ideológica que "glorificaba" el museo moderno, fue Brian O'Doherty con su publicación "Dentro del Cubo Blanco. La ideología del espacio expositivo" (1976).

Otro texto influyente sobre la crítica al museo, donde se plantea la pérdida del aura (ya preconizada por Walter Benjamin en "La obra de arte en la época de su reproductibilidad técnica", 1936), la pérdida del poder institucional de la autoría y, en definitiva, resalta la "muerte" del museo (a partir del análisis de ciertas obras literarias, filosóficas y artísticas del siglo XX): "Sobre las Ruinas del Museo" (October1980) de D. Crimp, uno de los autores más destacados dentro de la crítica del arte en Norteamérica.

[6] Rosalind Krauss es una de los autores, junto con otros como Carol Duncan y Allan Wallach, pioneros en el análisis del control social ejercido desde el museo y en la denuncia de la conversión del museo en parque temático orientado hacia el espectáculo y el consumo de masas, para Krauss el Guggenheim de Bilbao sería el iniciador de esta tendencia (Krauss 1995: 25).

[7] Tal y como profetizó en 2008 el famoso arquitecto del Guggenheim bilbaino Frank Gehry: "Un edificio puede funcionar muy bien si tiene un programa claro y una función clara. Dicho de otro modo, si es necesario" (Cita extraída en "La burbuja de los museos", El País-Babelia, 14-05-11: 18).

[8] La revista museo.es a finales de 2009 realizó, con motivo de la celebración del III Encuentro Iberoamericano de Museos bajo el lema "Los Museos en un contexto de crisis", una encuesta en torno a la incidencia de la actual crisis en las instituciones museísticas. Las diferentes opiniones recogidas en este artículo han sido publicadas también por Mario Chagas en: "Los museos en el marco de la crisis", revista Museos.es, no 5-6 (2009-10: 86-101). Véase también: Oscar Navarro y Christina Tsagaraki, "Museos en la crisis: una visión desde la museología crítica" Op. Cit. 50-57. Yves Bergeron "Los museos y la crisis. Tendencias en los museos norteamericanos", Op. Cit. 58-67.

[9] Según declaraciones de César Rendueles (adjunto a la dirección del Círculo de Bellas Ates de Madrid): "Incluso para los partidarios de la mercantilización del arte, se ha llegado a momentos de irracionalidad [...]. La rentabilidad del arte, desde los años 70, es puramente especulativa y es una inversión financiera [...]. Ha habido una burbuja de financiación pública, no es razonable que se haya creado un centro de arte público en cada pueblo de 20.000 habitantes" (Rendueles 2012: 5).

[10] En la publicación de la Universidad Internacional de Andalucía (UNIA), 10.000 francos de recompensa. El museo vivo o muerto, Cesar Antonio Molina indicaba en la introducción cómo "El arte 
contemporáneo goza en España de una estupenda salud. Una prueba de ello es el surgimiento en los últimos años de un importante número de museos y centros de arte [...]" (Molina 2009).

[11] “La misión del museo consiste en ser una herramienta fundamental en la creación de sentido colectivo en cuanto al arte y la cultura. La misión actual del museo es vertebrar y reelaborar la idea de museo desde un punto de vista ciudadano cercano al conocimiento y al saber. Así el museo plantea su función dotando de estrategias de actuación y de herramientas criticas de análisis la relación del arte con la sociedad a todos sus niveles en el periodo en el que mueve la Colección del Museo y su programación 1989- actualidad, pero siendo conscientes que la contemporaneidad engloba parte de la historia anterior. [...] La misión del museo con esta Colección, como piedra base, es conservador, difundir, estudiar e hilvanar de una manera amplia y panorámica la importancia del arte en la contemporaneidad en este intervalo de tiempo, bajo premisas conceptuales y sociales que pongan de manifiesto la importancia y la relación del arte en momentos y situaciones sociales, políticas, culturales y estéticas como un verdadero catalizador del momento en que estas obras fueron producidas a través de los diversos discursos generados en la exposiciones de la Colección tanto dentro como fuera del propio museo. [...]" http://musac.es/index.php?secc=1 \&subsecc=1.

Por ultimo hay que hacer hincapié en la misión difusora a través de todos los medios y sobretodo de la nuevas tecnologías y plataformas digitales, pero sobre todo en su vertiente educativa y colectiva, puesto que a través de los innumerables jornadas, seminarios, ciclos de cine, y video, performances, talleres de artistas, visitas guiadas, grupos de discusión, etc. que dan a la educación artística y al pensamiento un interés que va mas allá del programa, importancia tanto a los procesos de trabajo en lo expositivo, en el pensamiento como en la educación desde el museo. Por ello la misión fundamental es el acercamiento de todos estos conocimientos y labrar una red de relaciones artísticas la comunidad artística ya sea esta de Castilla y León; de otros ámbitos nacionales o internacionales.

En definitiva el Museo viene a ser como una gran ciudad donde los diferentes agentes, personas que se acercan que la habiten pueden encontrar un lugar de encuentro para la estudio, investigación, discusión, análisis y disfrute del arte y la cultura contemporáneas."

[12] Así lo expresaba también el propio Hans Ulrich Obrist, uno de los comisarios de arte contemporáneo más predominantes en la actualidad y codirector de la Serpentine Gallery londinense, en la entrevista de Elena Vozmediano, "hoy todo es grande, pero creo que el modelo macro-exposición se está hudiendo" (El Cultural, 22-11-2007).

[13] Hans U. Obrist, "When Attitudes Become Form de Harald Szeemann. (Los hitos del arte. 1969: el papel del comisario)", El Cultural, 16-10-2009. Así como la publicación de Hans Ulrich Obrist, $A$ brief history of curating, JRP / Ringier, 2008. [Ed. castellano: Breve historia del comisariado, Madrid, Exit publicaciones, 2010].

[14] Como ejemplo cercano, el Museo Nacional del Prado en 2011 ingresó $11.702 .512 €$, gracias a un notable ascenso de visitantes. Sin embargo, como consecuencia de los recortes de aportación Estatal a la misma, en estos últimos años se ha incrementado el precio de la entrada a un $15 \%$, con el fin de "poder garantizar el cumplimiento de sus funciones", tal y como anunció en El Confidencial el director del museo Miguel Zugaza. Asimismo, debido al declive del turismo, Zugaza prevé una bajada del $15 \%$ de visitantes para el próximo año y, en consecuencia, en recursos propios. Una caída de público que se percibiría por primera vez, desde hace mucho tiempo, en el Museo del Prado. Sobre ello véase, Peio H. Riaño (6/2/2013): "El Prado sube un 15\% su entrada para evitar el cierre y Zugaza prevé una caída de visitantes". El Confidencial.com

[15] En su simposio: Hacia una nueva institución, junto con otros agentes culturales (curadores, historiadores del arte, etc.), en los Encuentros sobre Comisariado, impartido por la UNIA, que han tenido lugar el pasado septiembre de 2012 en el Centro Andaluz de Arte Contemporáneo (CAAC).

[16] Cuestiones relacionadas con lo regional y lo global, en concordancia con temas abordados últimamente por el ICOFOM: con la Diversidad, con la Memoria, con lo Intangible, con el Desarrollo social y sobre todo con la Ética, como programa filosófico de la nueva Museología. Léase: André 
Devallés. Muséologie, Patrimoine, changement économique et developpment social. ICOFOM Study Series-ISS $33^{\mathrm{a}}$.

[17] A modo de ejemplo, el pasado día 1 de Marzo de 2013 se inauguró el Museo de Arte de Río de Janeiro (MAR), un museo construido en una antigua comisaría de policía de la dictadura brasileña. Además de contener ya una colección de 3.000 piezas con 50 donantes, alternando espacios para exposiciones de arte contemporáneo y otras de colecciones privadas o temáticas, se dedica principalmente a la formación continua de profesores y alumnos de barrios deprimidos (El País, 7-32013:47)

[18] En torno a ello un clásico es el estudio de Pierre Bourdieu, L'amour de l'art. Les musées d'art européens et leur public (1969).

[19] Tal y como expresa Anna M. Guasch: "Crisis de financiación, crisis de audiencias, crisis de significado, crisis de legitimación política, crisis de arte de vanguardia, crisis de arquitectura y crisis de mercado" (Guasch 2008: 10-12).

\section{Bibliografía}

ADORNO, T. W. (1962). "Valéry Proust Museum". Prismas. La crítica de la cultura y la sociedad. Barcelona: Ariel, 187.

ADORNO, T. y HORKHEIMER, M. (1998) (1944). Dialéctica de la llustración. Fragmentos filosóficos. Madrid. Trotta.

AMENDOLA, G. (2000). La Ciudad Postmoderna. Magia y Miedo de la Metrópolis Contemporánea, Madrid: Celeste, 183-209.

BADIA, M. (2011). "El comisariado en crisis. Notas a partir de los modelos curatoriales de Manifiesta". A*Desk (Critical Thinking). 71. http://www.a-desk.org/spip/spip.php?article882 [Consulta: 12/1/2011]

BALLART, J. (2007). Manual de museos, Madrid: Ed. Síntesis.

BARÓN F. (2013). "De la sala de tortura a la sala de arte". El País-Cultura, 47.

BARTHES, R. (2009) (1 a ed. París, 1984). “La muerte del autor” (1968), en el Susurro del Lenguaje. Más allá de la palabra y la escritura, Barcelona: Paidós, 75-84.

BENJAMIN, W. (1973) (1 a ed. alemana, 1972). “La obra de arte en la época de su reproductibilidad técnica” (1936) en Discursos Interrupidos I. Madrid: Taurus.

BOURDIEU, P. (2003) (1969). El amor al arte. Los museos europeos y su público, Barcelona: Paidós.

BOURRIAUD, N. (2008 3aed.) (1998). Estética Relacional, Buenos Aires: Adriana Hidalgo, 6-8.

CARRILLO, J. (2008). “Las nuevas fábricas de la cultura: los lugares de la creación y la producción cultural en la España contemporánea".

http://www.anticteatre.com/mov_8octubre/J.Carrillo_nuevas_fabricas_de_la_cultura.pdf [Consulta: 9/12/2012]

CARRILLO, J. (2012): "Hacia una nueva institución". Simposio en el encuentro sobre Introducción al Comisariado, Sevilla: UNIA Y Centro Andaluz de Arte Contemporáneo (CAAC).

CARRILLO, J. (2012). "Las instituciones culturales y la reformulación del espacio público". Conferencia en XXIII Sesión del VI Curso de Introducción al Arte Contemporáneo 2011-2012, MUSAC. En línea: https://vimeo.com/43113771 [Consulta: 24/1/2013].

CHAGAS, M. (2009-10). "Los museos en el marco de la crisis", revista Museos.es, 5-6: 86101.http://es.calameo.com/read/000075335586d490a82c6 [Consulta: 8/10/2012]

COLLERA, V. (2011). “La burbuja de los museos”, El País-Babelia, 18. 
CRIMP, D. (2005). "Sobre las ruinas del museo" (October 1980), enPosiciones críticas. Ensayos sobre las políticas de arte y la identidad, Madrid: Akal, 61-72. El mismo texto aparece también publicado en español en: FOSTER, H. (1998) (1983): La Postmodernidad. Barcelona: Kairón, 75-92.

DEVALLES, A.. Muséologie, Patrimoine, changement économique et developpment social. ICOFOM Study Series ISS $33^{\mathrm{a}}$.

DOUGLAS, D. (1990). The Museum Transformed: Design and Culture in the Post-Pompidou Age. New York: Abbeville Press Publishers, 16.

ESPEJO B. (2012). "por dónde pasa el futuro del comisariado?", El Cultural.es.

http://www.elcultural.es/version_papel/ARTE/31299/Por_donde_pasa_el_futuro_del_comisario [Consulta: $6 / 7 / 2012$

GIEBELHAUSEN, M. (2011). "The architecture is the museum". EnNew Museum Theory and Practice: an introduction, Marstine, J. (ed.). USA: Blaclwell Publishing, 41-63.

GUASCH, A. M. y ZULAIKA, J. (2007). Aprendiendo del Guggenheim de Bilbao. Madrid: Akal, 13.

GUASCH, A. M. (2008). "Los museos y lo museal". Revista Calle 14. 2. Universidad de Barcelona. 10-22. http://annamariaguasch.net/pdf/MUSEOS_LO_MUSEAL.pdf [Consulta: 17/9/2011]

GUASCH, A. M. (2009). El arte del siglo XX en sus exposiciones, 1945-2007, Barcelona: Ed. Serbal.

GUASCH, A. M. (2011). Arte y Archivo, 1920-2010, Madrid: Akal, 42.

HUYSSEN, A. (2002). En busca del futuro perdido: Cultura y memoria en tiempos de globalización, Buenos Aires: Fondo de Cultura Económica y Goethe Institut.

KING, L., y MARSTINE, J. (2011) (2006). “The University Museum and Gallery: A site for institutional critique and a focus of the curriculum" en New Museum Theory and Practice: an introduction, USA: Blaclwell Publishing, $266-291$.

KRAUSS, R. (1995). "La lógica cultural del museo tardocapitalista", Museos de Vanguardia, Monografías de Arquitectura y Vivienda, 39: 25.

KRAUSS, R. (2005). "Postmodernism's Museum without Walls" en Thinking about Exhibitions, Routledge, 241245.

LIPOVETSKY, G. (2003). La era del vacío: Ensayos sobre el individualismo contemporáneo, Madrid: Anagrama.

LÓPEZ, J. R. (2010). Historia de los museos de Andalucía 1500-2000, Universidad de Sevilla: Secretariado de Publicaciones, 538.

LOSADA, J. C. (2010). Comunicación en la gestión de crisis, Barcelona: Editorial UOC, 21.

MALRAUX, A. (1965) (1947).Le musée imaginaire. París, Gallimard.

MANEN, M. (2012): Salir de la Exposición (si es que alguna vez habíamos entrado), Bilbao, Consonni, 100.

MEIJERS, D. (1996). "The Museum and the 'ahistorical' exhibition", Thinking about exhibitions, Londres: Routlege, 5-14.

MONTANER, J.M. (2003). Museos para el Siglo XXI. Barcelona: Gustavo Gili.

OBRIST, H. U. (2009). "When Attitudes Become Form de Harald Szeemann. (Los hitos del arte. 1969: el papel del comisario)", El Cultural.es

http://www.elcultural.es/version_papel/ARTE/26005/When_Attitudes_Become_Form_de_Harald_Szeemann [Consulta: 16/10/2009].

OBRIST, H. U. (2010) (2008). Breve historia del comisariado, Madrid: Exit publicaciones.

O'DOHERTY, B. (1999) (1976). Inside the White Cube. The ideology of the Gallery Space. Berkeley, Los Ángeles, Londres: University of California Press. 
RENDUELES, C. (2012). "¿Quiénes deciden el valor real de las obras de arte?", El Confidencial. http://www.elconfidencial.com/alma-corazon-vida/2012/02/18/quienes-deciden-el-valor-real-de-las-obrasde-arte-92816/ [Consulta: 18/2/2012].

RIAÑO, P. H., (6/2/2013). “El Prado sube un 15\% su entrada para evitar el cierre y Zugaza prevé una caída de visitantes". El Confidencial.

http://www.elconfidencial.com/cultura/2013/02/06/el-prado-sube-un-15-su-entrada-para-evitar-el-cierre-yzugaza-preve-una-caida-de-visitantes-114390/ [Consulta: 6/2/2012].

Site del MUSAC (2013). "Misión del Museo": http://musac.es/index.php?secc=1\&subsecc=1 [Consulta: $11 / 1 / 2013]$

VILLEL, M. B. (2012). "Atención: riesgo de amnesia", El País Cultura.http://cultura.elpais.com/tag/arte/a/ [Consulta: 19/10/2012].

VOZMEDIANO E. (2007). “Hans Ulrich Obrist: Hoy todo es grande, pero creo que el modelo macro-exposición se está hundiendo". El Cultura.es

http://www.elcultural.es/version_papel/ARTE/21755/Hans_Ulrich_Obrist/ [Consulta: 22/11/2007].

V.AA. (2009). 10.000 francos de recompensa. El museo vivo o muerto, Barcelona: ADACE, SEACEX, UNIA (ed).

V.AA. (2013). "Los profesionales de los museos dan la voz de alarma sobre su precariedad". El Confidencial. http://www.elconfidencial.com/cultura/2013/03/26/ [Consulta: 26-03-13].

ZULAIKA, J. (1997). Crónica de una seducción: el museo Guggenheim de Bilbao, Hondarribia, Nerea.

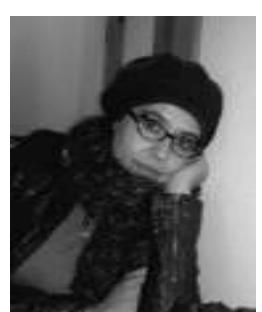

Susana Solís Zara

s.soliszara@gmail.com

http://susanasoliszara.virtualgallery.com

Es Licenciada en Bellas Artes por la Universidad de Sevilla. Centro en el que obtuvo el Diploma de Suficiencia Investigadora (DEA) y donde, en la actualidad, realiza su tesis doctoral (de contenido vinculado al presente artículo), conjugando su labor de investigadora con la práctica artística gráfico-plástica.

También es miembro del grupo de investigación HUM 552: Artana (Plástica y Arte Anatómico), adscrito al Departamento de Dibujo, perteneciente a la línea de investigación plástica y gráfica.

Artículo envío el 04/03/2013

Artículo aceptado el 13/05/2013 


\title{
Principios de conservación en una tecnología de restauración innovadora en el Patrimonio Arqueológico. Aplicación en el Proyecto ARQUEOLÁSER
}

\author{
Joaquín Barrio Martín
}

\begin{abstract}
Resumen: La finalidad de este trabajo es poner de relieve lo que las nuevas tecnologías que nos están llegando al sector de los bienes patrimoniales, pueden aportar soluciones a problemas de restauración que los procedimientos tradicionales no habían conseguido resolver o bien que el resultado obtenido no era el más adecuado para una adecuada conservación de las piezas arqueológicas. Pero en modo alguno, la implantación de estos métodos innovadores debe hacerse de manera aislada, sino en estrecha colaboración y complementación con las técnicas tradicionales; no deben ser nunca considerados un sustituto sino un apoyo importante, a veces imprescindible, en la tarea común de conservar nuestro Patrimonio Arqueológico más vulnerable.
\end{abstract}

En este contexto, es cada día más patente que el láser es una aplicación innovadora relevante en los materiales arqueológicos que necesitan ser restaurados, especialmente cuando éstos presentan procesos de alteración y paquetes de corrosión muy resistentes, que los procedimientos tradicionales no consiguen solventar con total garantía. Este es el caso especialmente de muchas piezas metálicas.

Por esta razón, el láser aplicado en la restauración de estos elementos presenta unas expectativas excelentes, pero que deben de sustanciarse en el corto plazo profundizando en la investigación con ayuda de la Arqueometría, pero también en la definición de un Protocolo de Trabajo que se adscriba a principios de la conservación en estos comienzos del siglo XXI.

Palabras clave: Patrimonio, Arqueología, Principios, Conservación, Restauración, Tecnologías de Innovación, Láser.

\section{Princípios de conservação numa tecnología de restauro inovadora no patrimonio arqueológico. Aplicação do projecto ARQUEOLASER}

Resumo: O objectivo deste trabalho é realçar como as novas tecnologías que estão a chegar ao sector dos bens patrimoniais podem trazer soluções a problemas de restauro que os procedimentos tradicionais não conseguiram resolver ou que o resultado obtido não foi o mais adequado para uma correcta conservação de peças arqueológicas. No entanto, de modo algum, a implementação destes métodos inovadores deve fazerse de forma isolada mas sim, em estreita colaboração e complementariedade com as técnicas tradicionais; nunca devem ser considerados como substitutos e sim, como um apoio importante e, às vezes imprescendível, na tarefa comum de conservar o nosso patrimonio arqueológico mais vulnerável.

Neste contexto, é, cada dia mais patente que o laser é uma aplicação inovadora relevante para os materiais arqueológicos que necessitam ser restaurados, sobretudo quando estes apresentam processos de alteração e áreas de corrosão muito resistentes, que os procedimentos tradicionais não conseguem resolver com total garantía. Este é, especialmente, o caso de muitas peças metálicas.

Por esta razão, o laser aplicado para restauro destes elementos apresenta umas expectativas excelentes, mas que se devem consubstanciar a curto prazo, aprofundando a investigação com a ajuda da Arqueometria mas também, com a definição de um protocolo de trabalho adstrito a princípios de conservação, neste inicio do século XXI.

Palavras-chave: Património arqueológico; princípios; conservação; restauro; tecnologias de inovação; laser. 


\section{Conservation principles in an innovative restoration technique of archaeological heritage. ARQUEOLASER Project}

Abstract: The aim of this study is to emphasize how new technologies with recent application on cultural heritage are providing solutions to unsolved conservation problems, untreatable with traditional procedures. However, these techniques should never be used isolated, but in narrow collaboration with traditional systems; they shouldn't be considered a substitute, but an important support, sometimes even indispensable, in the purpose of conserving our vulnerable archaeological heritage. In this context it becomes very clear that laser has a relevant application in the restoration of archaeological materials, especially when they

Show an advanced alteration and resistant corrosion layers. This is the case of many archaeological metals. For this reason, conservation treatments based on laser reveal excellent expectations that should be substantiate with profound research, helped with Archaeometry and the definition of working protocols ascribed to conservation principles, at the beginning of the 21 st Century.

Keywords: Heritage, Archaeology, Principles, Conservation, Restoration, Innovation technologies, Laser.

\section{Introducción}

Después de una experiencia de trabajo de varios años investigando la aplicación de estas técnicas LASER en bienes arqueológicos, es mi intención hacer ahora una valoración concluyente de algunos aspectos recogidos en dos proyectos i+D (METALÁSER hasta julio 2012 y el actual ARQUEOLÁSER )', que tienen más que ver con los procedimientos y la filosofía de trabajo; quizás pueda recogerse bajo el paraguas de lo que debemos denominar Etica del Patrimonio, en consonancia con lo que se hace en otras ciencias como la Biología o la Medicina. Quiero indicar, por tanto, que la intervención directa sobre un bien de P. Arqueológico debe estar rigurosamente justificada por un diagnóstico, y orientada a la recuperación y la conservación del objeto, además de responder a los principios y protocolos de acción determinados, emanados de las normas internacionales referidas a la deontología de la conservación y restauración en estos primeros decenios del siglo XXI. El significado histórico y valor documental de cada pieza arqueológica obligan a ello. Una vez decidida la necesidad de intervenir es preciso alcanzar una solución óptima utilizando algunos criterios generales que garanticen "a priori" la fiabilidad, seguridad y durabilidad de los procedimientos de la restauración. No en vano ICOM (2006) como primera institución mundial en la conservación y cuidado de los bienes culturales dejó manifiesto hace unos años en su Código Deontológico, directriz 3.5, al hablar de las investigaciones que se llevan a cabo en estos objetos, que "... deben ser conformes a las prácticas jurídicas, éticas y académicas establecidas...".

Ante todo, es necesario efectuar una elección razonada, tras un cuidadoso análisis comparativo de diferentes hipótesis y pruebas reales, en función de la solución que se pretende llevar a cabo ejecutando la intervención sobre el objeto arqueológico. Esta solución debería ser preferentemente integral para que la intervención sea lo más general y, en cierto modo, lo más repetitiva posible y por tanto, lo más controlable posible en sus efectos en el futuro. Para ello conviene haber definido con claridad un Protocolo de Trabajo, a semejanza de lo que se sigue en otros ámbitos como la Cirugía Clínica, con la que tánta similitud tiene la Restauración, obviando indudablemente las diferencias en el sujeto. 
Para que mi presentación y análisis de estos problemas no resulten etéreos, y sabedor de que la restauración es por antonomasia una ciencia matérica, añadiré un caso particular donde ver reflejado el trabajo con esta tecnología láser y la adscripción a los principios de la conservación.

\section{Nuevas tecnologías para la conservación y restauración y principios deontológicos en el siglo XXI}

Para abordar este análisis es preciso considerar la conexión entre Restauración y Arqueología, puesto que estamos entrando de lleno en un ámbito de competencias compartidas; no se puede olvidar que los objetos a intervenir son recuperados y estudiados por esta ciencia histórica. El interés que desde el campo de la Arqueología se ha tenido en participar e influir en los foros donde se han definido los principios de la restauración moderna siempre ha sido importante. Hay que referirse en estos precedentes, sin duda, a la participación de personalidades de envergadura como el arquitecto, arqueólogo y restaurador L. Torres Balbás en las discusiones que dieron lugar a documentos deontológicos como la Carta de Atenas en 1931, la primera de estas normas que conducirán la actividad de la restauración y conservación desde el primer tercio del siglo XX hasta el siglo XXI, inaugurado con la Carta de Cracovia en el 2000. Se inscribe lógicamente en esa clara implicación de los dos ámbitos para conseguir un objetivo común: lograr que los bienes del Patrimonio Arqueológico puedan ser legados a las futuras generaciones en las mejores condiciones de conservación posibles. Y ejercer esta responsabilidad ateniéndose a unos ineludibles valores éticos, además de seguir con precisión los principios científicos de la técnica láser en su aplicación a bienes arqueológicos y artísticos (Siano 2007).

Desde este marco de intereses patrimoniales compartidos por arqueólogos, conservadores y restauradores, conviene evaluar los principios profesionales que deben guiar las restauraciones sobre bienes arqueológicos (metales en especial) con esta tecnología láser, innovadora en nuestro campo. A pesar de que las Cartas y Documentos deontológicos de Restauración apenas hacen alguna consideración concreta sobre la intervención en metales arqueológicos, de su lectura detenida se pueden entresacar algunos principios generales que han guiado la actuación en mi trabajo; hoy en el Proyecto ARQUEOLÁSER.

En este sentido, una anotación de contenido demasiado general referida a la restauración de los metales arqueológicos es la que se recoge tanto en la Carta del Restauro de Roma de 1972 como en la Carta de Restauro de 1987 (Anexo A dedicado a la salvaguardia y restauración de Antigüedades) en estos términos:

"...Se impone una delicadeza especial al recoger objetos o fragmentos de metal, sobre todo si están oxidados, recurriendo, además a sistemas de consolidación, también a soportes adecuados cuando sea necesario...".

Este es, pues, el único texto que hace alguna alusión concreta y general a los metales arqueológicos, sin entrar en los procedimientos de restauración tradicionales o innovadores.

La utilización de una nueva tecnología como el láser en un campo tan delicado como el de la conservación y restauración de los metales de procedencia arqueológica, en el que aún no se cuenta con una experiencia internacional y nacional consolidada, también debe tener el sustento de los principios deontológicos más actuales. 
Al surgir como tal investigación aplicada y hacerlo en los últimos años, se ha regido en su desarrollo por hacer un uso constante del apoyo de las ciencias analíticas y experimentales. Este es un criterio que ya fue apuntado en la Carta de Atenas de 1931 y recogido más explícitamente en la Carta de Venecia de 1964 al promover la solicitud de "...el apoyo de las ciencias y las técnicas para colaborar y cumplir perfectamente con el cometido final de la conservación..." (Art'2). Un criterio de actuación que con el paso del tiempo se ha hecho más evidente, conduciendo la tarea de conservación y restauración hacia una actividad multidisciplinar, que debe ir más allá del habitual análisis antes de... de los productos de alteración y causas de deterioro, y llevar a evaluar después de... con las técnicas más adecuadas a cada caso los resultados logrados con cualquier técnica innovadora; y el láser no puede quedar al margen de esta premisa. A este mismo respecto, en la Carta de Cracovia del 2000 ( $\left.\mathrm{Pt}^{\circ} 10\right)$ se dice:

"...Las técnicas de conservación o protección deben estar estrictamente vinculadas a la investigación pluridisciplinar científica sobre materiales y tecnologías usadas... Cualquier material y tecnología nuevos deben ser probados rigurosamente, comparados y adecuados a la necesidad real de la conservación...".

Este principio de validación de un nuevo proceso con técnicas científicas es a todas luces uno de los criterios principales que afectan a las nuevas tecnologías. El tiempo, como tantas veces, dará rúbrica o no a esta técnica.

Más recientemente, al definir ICOM-CC la terminología actual de la conservación-restauración, hace hincapié en los considerandos del preámbulo con estas palabras: "... any measures and actions taken result from an inclusive interdisciplinary decision-making process..." (ICOM-CC, 2008).

Como se pone de manifiesto en ese párrafo de la última Carta de Restauración, hoy está perfectamente justificado el uso de tecnologías de vanguardia como el láser, siempre que se acompañen de estudios científicos que vayan convalidando la aplicabilidad de la técnica y su aportación positiva a las tareas de la conservación en la resolución de los problemas junto métodos tradicionales bien conocidos y experimentados en el tiempo.

En la restauración de materiales arqueológicos metálicos, un criterio aceptado en la deontología internacional, quizás el de mayor transcendencia, es el referido a la recuperación de la superficie original y el mantenimiento de su pátina. Desde hace algunos años, un buen número de investigadores y restauradores, entre los que me encuentro, hemos hecho un hincapié preferente de este criterio en nuestros trabajos. Pero sin duda, ha sido el Profesor R. Bertholon, quien ha focalizado muy especialmente este problema conceptual, pero también objetivo y material, y ha entrado con detalle en su análisis (2000: 99-140).

Así pues, la intervención restauradora de estos objetos, generalmente muy afectados por un grave deterioro (nos acogemos a la denominación de las cuatro zonas de corrosión propuesta por Chitty et al. 2005), debe conllevar la eliminación de las tierras del propio contenedor del suelo (Soil, [S]) y de la mezcla de óxidos y tierras que forman el estrato más externo de los productos de alteración (Transformed Médium, [TM]). Y ha de dejar a la vista la capa más densa (Dense Product Layer, $[D P L]$ ), que integran mayoritariamente una mezcla de óxidos, hidróxidos y carbonatos (ghoetita, magnetita y maghemita en el caso de los hierros; tenorita, cuprita y malaquita en el de los cobres/bronces), suficientemente densos para evitar la difusión de oxígeno (estabilidad frente a la corrosión). En esta capa es donde es posible que encontremos todo lo que se conserva de la forma 
original del objeto, y por ende, su pátina. En la intervención no debemos llegar y dejar a la vista el núcleo metálico interno (Metal, [M]). Es verdad que a grandes rasgos la forma se mantiene en estos objetos, pero sabiendo que la corrosión y la mineralización añadida suelen llevar aparejado un aumento ligero en dimensiones o una pérdida de materia, según los casos, en la estructura metálica que compone la pieza.

Consecuentemente en el trabajo con el láser ha de primar en todo momento el respeto de la autenticidad de las piezas metálicas. Viene ya recogido en la introducción a la Carta de Venecia de 1964, y se hacen referencias a su importancia en el resto de los documentos normativos. Sin embargo, es en la última Carta, la de Cracovia ( $\mathrm{Pt}^{\circ}{ }^{6}$ ) donde se confiere a este principio una importancia destacable, estando incluido en el apartado de Definiciones. A partir de su lectura, esta autenticidad cabría definirla "como la cualificación sustancial de la obra derivada de la suma de las características intrínsecas y propias de dicho Bien Cultural, tanto materiales como inmateriales, que han sido determinadas como resultado de las transformaciones ocurridas en el tiempo". Por tanto, la autenticidad debe reconocerse tanto del contenido material como del inmaterial de la pieza (en la materia física constituyente y en el contenido histórico representado). Este rasgo que protege el principio mencionado parece imprescindible en los bienes del Patrimonio Arqueológico, quizás porque la autenticidad es la referencia más obligada y necesaria para los elementos pertenecientes a las denominadas culturas antiguas.

Así, el respeto a esta identidad auténtica es uno de los principios fundamentales en las actuaciones englobadas en el proceso de conservación/restauración, y sobre todo, con las nuevas herramientas tecnológicas. Esta actitud es hoy preferente a la hora de intervenir, aún siendo consciente que toda intervención sobre metales arqueológicos, dado su deficiente estado de conservación, lleva aparejada una cierta dosis de pérdida o modificación de esa autenticidad. Personalmente creo que es el láser la técnica que mejor puede preservar estas condiciones de autenticidad en muchos de estos objetos, pues permite un control exhaustivo de cada momento de la limpieza al avanzar unas pocas micras en cada pulso.

También, parece lógico que se debía de plantear el criterio general de mínima intervención que prima en la conservación moderna. Así pues, el proceso de restauración debe ser el mínimo exigible, con el objetivo primordial de la estabilización de las piezas metálicas y la garantía de permanencia de éstas en el futuro. Quizás siga siendo muy útil la premisa conocida de hace años restauración en función de la conservación, siempre privilegiando los aspectos preventivos antes que curativos, y ya expresada en su momento con claridad en las teorías brandianas (Brandi 1988: 55-61). Así mismo, la última Carta de Cracovia cuando se refiere a este criterio general lo hace con expresa mención en los términos siguientes: "...los trabajos de conservación de hallazgos arqueológicos deben basarse en el principio de mínima intervención,..." ( $\left.\mathrm{Pt}^{\circ} 5\right)$.

En consecuencia con este principio, la aplicación del láser en un tratamiento se ha de abandonar cuando se consiguen los objetivos de recuperar la materia física original, intacta o transformada en pátina, y así mismo las cualidades estéticas o históricas de las piezas arqueológicas.

Sin embargo, este principio debe de acomodarse al de recuperación de la legibilidad, esto es, la recuperación de la entidad de las piezas no sólo mediante el descubrimiento de sus superficies originales que hayan podido quedar de los distintos metales tratados, sino haciendo uso de las necesarias tareas de integración y reintegración, imprescindibles en la mayoría de los bienes de naturaleza arqueológica. 
En la tarea de recuperar una lectura correcta de la superficie de la pieza, la herramienta láser resulta muy apropiada para lograr este propósito, especialmente en hierros, aleaciones de base plomo o base cobre, bronces..., retirando los productos deformantes sin riesgos de fisuras o rayados. Las superficies que han permanecido en ubicación original logran mantenerse en ella sin dificultades. En el caso de objetos como los cobres dorados, su legibilidad sólo es posible si se efectúa una retirada completa de los productos de deterioro que se han acumulado en la superficie y que ocultan el oro; sin embargo, cuando peligra la pérdida de esta capa por la extrema resistencia de los productos cubrientes, se ha optado por mantener éstos a sabiendas que la definida legibilidad queda reducida parcialmente.

La unidad metodológica es un principio cuya importancia se ha destacado en los últimos años, por hacer referencia a los últimos documentos deontológicos. Y viene a indicar que todo el proceso debe discurrir con una metodología estricta y un control adecuado de toda la intervención. Puede parecer innecesario apuntarlo en la medicina, la bioquímica o la ingeniería. Pero a mi modo de ver no es baladí seguir insistiendo en las ciencias patrimoniales.

El desarrollo de los procedimientos que exige la intervención con técnicas láser en el $\mathrm{P}$. Arqueológico debe estar previamente definido en la propuesta de trabajo. Esta ha sido nuestra intención al desarrollar un Protocolo de Trabajo para el Proyecto ARQUEOLÁSER. La conservación científica ha dispuesto un modelo metodológico que va mejorando conforme se desarrollan los avances técnicos y se tienen mejores experiencias en los resultados de intervención en obra. Indudablemente, para ejecutar esta metodología con acierto, se debe contar con profesionales cualificados como restauradores de Patrimonio Arqueológico formados en el manejo de esta técnica innovadora.

También deben ajustarse estos nuevos procedimientos de restauración láser a un criterio de baja invasividad sobre las superficies de los metales en las que actúa para su limpieza y siempre que en la fase de prueba no se hayan detectado efectos nocivos sobre el objeto. Como la aplicación del láser se caracteriza especialmente por la ausencia de contacto físico con la materia del objeto sobre el que se interviene, no tiene ocasión el impacto de las presiones o vibraciones de los procedimientos físicos que se generan con los métodos mecánicos o manuales. Esta baja invasividad es más necesaria aún si se trabaja con piezas arqueológicas de extrema fragilidad (Barrio et al. 2012a: 73-74) o con superficies muy alteradas, en especial en aquellos que llevan capas de oro, nielados, aplicaciones de materia orgánica -hueso, marfil-,... Pero no sólo se reduce el impacto frente a las restauraciones mecánicas, sino que también se puede aminorar la presencia residual de productos químicos, si se opta por su aplicación de éstos, pues en materiales de elevada absorción por ser porosos es difícil evacuarlos al completo.

Desde esta perspectiva, es preciso esgrimir un criterio de sostenibilidad, puesto que no habrá riesgos de acción degradante a medio y largo plazo por la contaminación por productos químicos. La técnica láser cumple, pues, estas expectativas, siempre que se maneje con fiabilidad y precisión.

Lo que no cabe plantear como un principio obligado es el de reversibilidad. Se ha traído en muchos casos como un dogma de fe, difícilmente comprobable. $Y$ sólo en los menos se ha presentado como un criterio objetivamente evaluado y atribuido más al proceso que al producto (Appelbaum, 1987; Pasíes 2012). En el caso que analizo, la propia acción de la ablación generada por el láser es ensimisma irreversible; como lo es en mismo grado una limpieza mecánica o química. Los procesos 
de transformación o eliminación pueden detectarse y registrarse analíticamente o reconocerse físicamente, pero en modo alguno son retroactivos.

Como último principio deontológico, este Proyecto mantiene como objetivo principal la estrategia para su conservación a largo plazo, en consecuencia con lo que se recoge en la Carta de Cracovia (Apartado 3). El espíritu de esta recomendación se sustancia en un proceso de estudio en profundidad de las piezas por diversas técnicas analíticas y la aplicación durante la etapa de intervención restauradora de una técnica que genere condiciones de estabilidad propia frente al deterioro. A esta misma estrategia de estabilidad de los objetos restaurados se refiere el Código Deontológico para los Muesos del ICOM (2006), de manera concreta en la directriz 2.24 "Conservación y restauración de colecciones", se indica "...El principal objetivo debe ser la estabilización del objeto o espécimen...". Unos años después cuando ICOM-CC desglosa y concreta la terminología en nuestro campo, esta acción stabilization of corroded metals es recogida entre las propias que integran la que denomina conservación curativa (Remedial conservation) (ICOM-CC 2008).

En este sentido, el trabajo con láser sobre metales arqueológicos, por mi experiencia, ha aportado resultados esperanzadores para la conservación de estas piezas en buenas condiciones de cara al futuro. Así se ha recogido diversos trabajos publicados junto a otros investigadores (Barrio et al. 2006; Chamón et al. 2007). Pero para que se complete este principio de conservación a largo plazo de los objetos arqueológicos más vulnerables, debe abundarse en una estrategia de conservación preventiva en los museos donde finalmente las piezas serán depositadas. Por ello el ICOM había incluido en su directriz 2.23 sobre la Conservación preventiva "...La conservación preventiva es un elemento importante de la política de los museos....A los profesionales de museos les incumbe la responsabilidad fundamental de crear y mantener un entorno adecuado para la protección para las colecciones almacenadas, expuestas o en tránsito, de las que están encargados...". Sólo de esta manera se podría mantener la eficacia de un tratamiento.

\section{Caso de aplicación: restauración con láser de una falcata de la necrópolis ibérica de El Salobral (Albacete)}

No es mi idea dejar este artículo en un mero ensayo intelectual, sino bajar a la arena de la aplicación clínica, y hacerlo dentro de un programa de trabajo concreto en el Proyecto ARQUEOLÁSER. Cuando se opta por la técnica láser es porque el objeto presenta peculiaridades que impiden una limpieza completa y segura con una acción mecánica tradicional o química alternativa. Estas condiciones especiales que obligan a la búsqueda de una opción diferente para su intervención, pueden darse, cuando menos, en ciertos grupos de piezas metálicas con un estado de conservación muy singular, como el caso que presento.

La ejecución del Proyecto ARQUEOLÁSER lleva aparejada la puesta en práctica de un proceso pautado y progresivo (Protocolo de Trabajo-PT), que en el ámbito de la restauración tiene mucha importancia. Al ser el SECYR un Laboratorio con Certificación ISO-9001 (por el momento el único en España certificado para realizar trabajos de conservación y restauración de bienes arqueológicos), todo este proceso está recogido en nuestro Sistema de Calidad dentro de diferentes PT, aunque de manera más concreta en el PT 520. Este PT se atiene a los principios y criterios actuales de la 
restauración científica presentados y valorados en páginas precedentes, y conforme una modulación de aplicabilidad no dogmática en la que creo firmemente.

Se trata de una pieza excepcional, perteneciente al Museo de Albacete: una falcata de la necrópolis ibérica de El Salobral (Albacete) ${ }^{2}$, cuya restauración se realizó en el SECYR durante 2011 y 2012 dentro de proyectos i+D bajo mi dirección ${ }^{3}$. Corresponde a los registros SECYR 315 y 316 de SC Certificado. Fue el arma más importante depositada en el ajuar del guerrero enterrado bajo el Túmulo 2. Las dos fases de utilización de la necrópolis datan del V-IV a.C. (Blánquez, 1994); por tanto, la falcata $T 2$ es una pieza de una notable antigüedad.

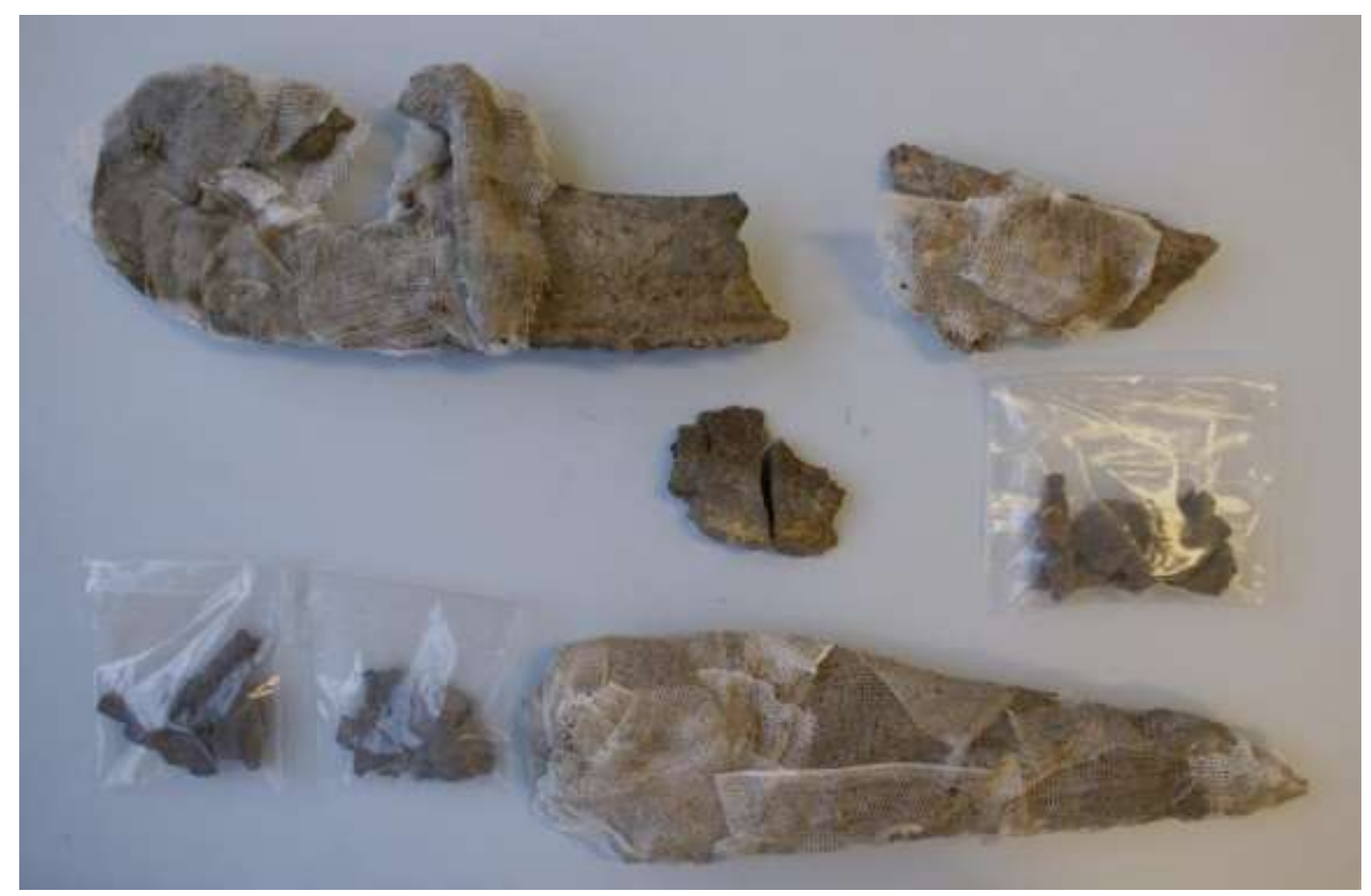

Figura 1. Vista general del estado de conservación inicial de la falcata T2 de la necrópolis ibérica de EI Salobral (Albacete): alta fragmentación, pérdida de material, intensa corrosión superficial. La técnica de extracción ha permitido mantener unidos muchos fragmentos.

Como se observa en las imágenes que adjuntamos, el estado de conservación es muy malo, calificado en el Nivel III. De manera abreviada, en este estadio integra las piezas que conservan poco o nada núcleo metálico, con un proceso de mineralización si no completa, sí a punto de llegar a su estado final. En todos los casos los objetos se caracterizan por su extrema fragilidad. Los hierros, como el que conforma esta falcata, pueden conservar la forma intacta con algún aumento volumétrico; pero cuando se trata de piezas férreas con nielados o cobres dorados la capa de dorado o los hilos de plata se encuentran ya encapsulados entre dos paquetes de corrosión muy sólidos y poco estables. Su eliminación completa es muy difícil sin arriesgar la pérdida de estas capas en metales nobles, por otra parte, menos corroídas que el substrato en atención a su distinta naturaleza electroquímica. 
Además de presentar un grado de corrosión muy severo la falcata T2 está completamente fragmentada [figura 1]. Esta situación se ha generado en buena medida porque ha llegado a una completa mineralización, que a su vez ha provocado la fragilidad de la estructura de hierro. Una de las causas que más ha pesado, sin duda, para generar el gravísimo estado de conservación de esta arma ha sido el proceso de cremación junto al cadáver del guerrero en la pira funeraria, donde la temperatura pudo alcanzar más de $900^{\circ} \mathrm{C}$. Y ello en connivencia con unas condiciones deposicionales del enterramiento de alta agresividad: elevada humedad, salobridad del terreno, irrigación cíclica, presencia de iones $\mathrm{Cl}-$..., como pusimos de manifiesto en la publicación de los resultados de la restauración de la falcata del Túmulo 1 de esta misma necrópolis ibérica (Barrio y Hermana 1998).

El núcleo interno compacto está formado por wustita, muy dura pero frágil y de fácil fractura. Debido a las abundantes roturas que ha sufrido durante el enterramiento algunas partes de la falcata T2 han perdido su conexión. A esta fragmentación, se une el desprendimiento laminar del hierro (hojaldrado) con pérdida de la superficie original en algunas áreas [figuras 2 y 3 ]. Especialmente sensible al deterioro ha sido la zona media-alta de la hoja por donde esta arma se había doblado ritualmente para inutilizarla y poder meterla en el pozo de enterramiento junto a la urna con sus cenizas y el resto de los elementos de su ajuar. Esta zona de falcata nos ha llegado incompleta, por lo que la recuperación de su legibilidad nos exigió un procedimiento más allá de la sola integración de los diversos fragmentos.

El paquete de productos de alteración sin ser muy espeso es bastante resistente. Más externamente muestra una capa porosa, agrietada, donde se amalgaman tierras, restos del consolidante e hidróxidos de hierro. Bajo ésta existe una segunda capa más compacta formada en mayor medida por productos de corrosión del hierro [figura 4]. Es importante destacar que gracias a que se recuperó en la excavación por medio de un engasado superficial impregnado con un consolidante nitrocelulósico su estado no es aún peor (vid. figura 1). Tengo que decir, haciendo justicia a los restauradores que ejecutaron estos trabajos en el yacimiento, que si la extracción no se hubiese hecho de manera tan cuidadosa y con apoyo de una eficaz consolidación, la falcata nunca podría haberse salvado. Esta actuación evidencia un criterio correcto y riguroso de conservación preventiva que debiera ser una norma de obligado cumplimiento en la extracción in situ de piezas metálicas.

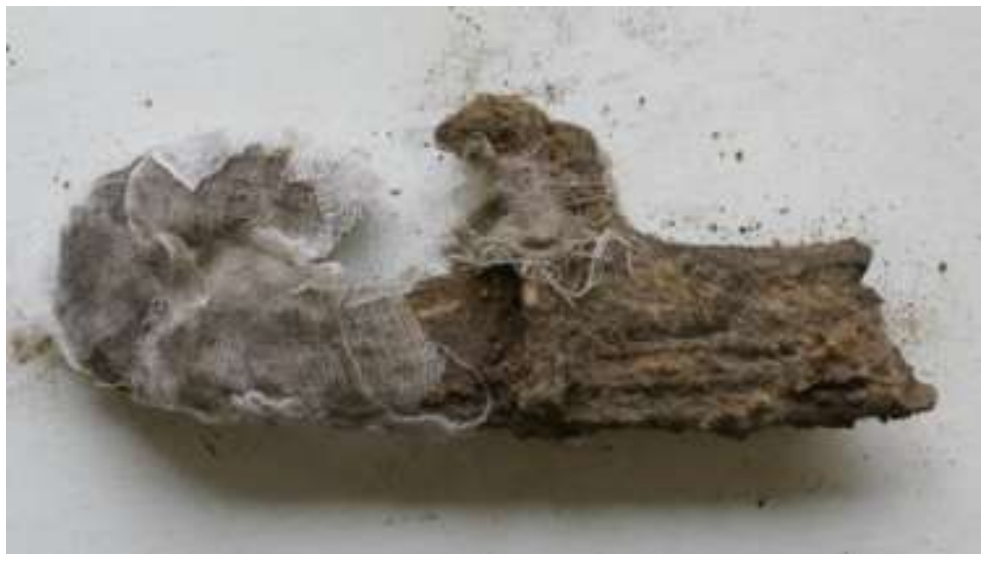

Figura 2. Empuñadura de la pieza donde se aprecia bajo los engasados la potencia de la capa de productos de alteración amalgamados con tierras. Se observa la pérdida de pequeños restos de corrosión. 


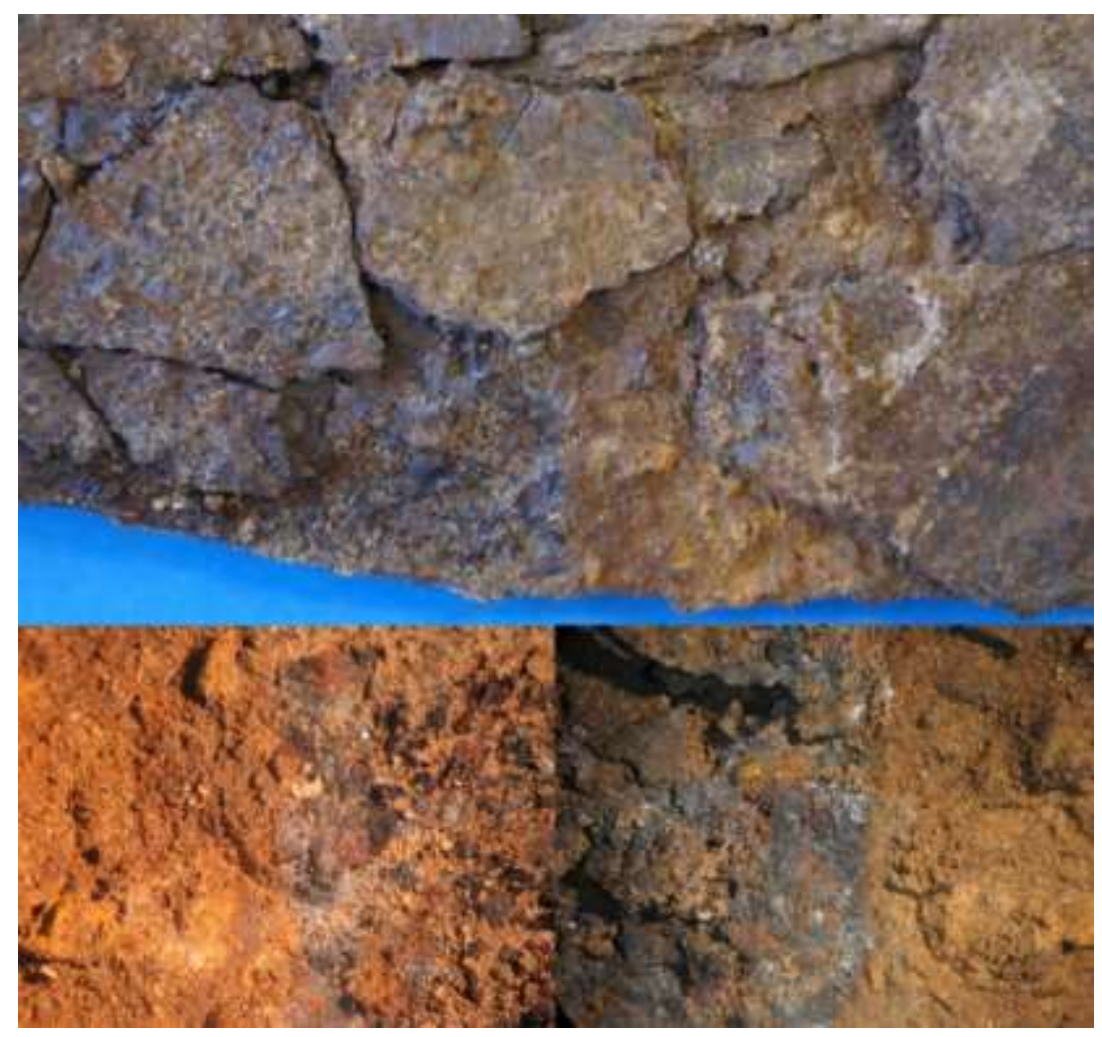

Figura 3. Imágenes de la superficie de la hoja de la falcata que detallan la extrema delaminación. En las inferiores de aprecian los primeros resultados de la acción del láser sobre los productos de corrosión del hierro.

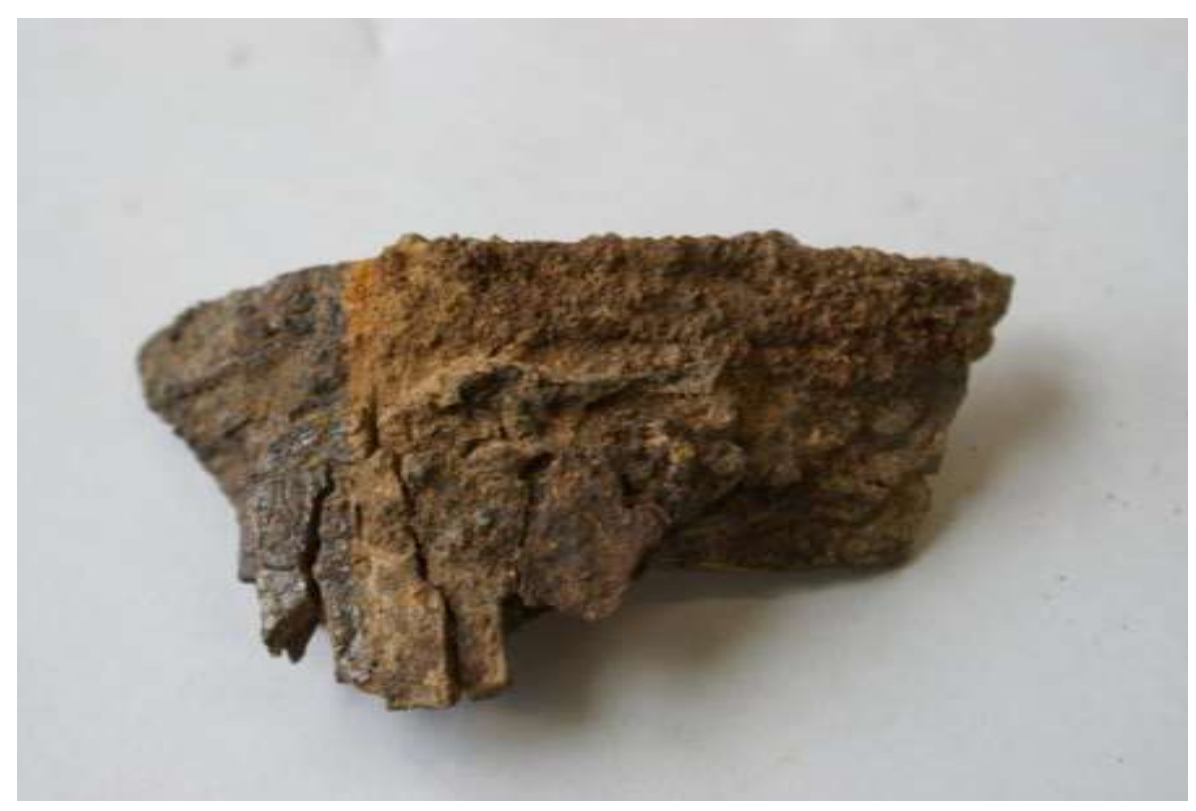

Figura 4. Fragmento de la zona media de la falcata $T 2$ afectada los numerosas grietas formadas en la estructura mineralizada generadas por la tensión en la zona de doblez de la hoja; en la parte izquierda se ha realizado una primera limpieza con láser. 
Previamente a cualquier intervención se realiza un análisis radiológico ${ }^{4}$. Las imágenes visibles de $\mathrm{RX}$ reafirman el diagnóstico del interior de las estructuras, donde apenas quedan restos de núcleo metálico. Se perciben bien tanto las áreas de mayor intensidad en la corrosión como los detalles de los roblones o espigas de la empuñadura. Se reconocen las fisuras más importantes que penetran en el interior de la pieza. Todos estos detalles permiten acercarse con precisión a la tecnología metalúrgica de esta pieza [figuras 5 y 6 ].

Para investigar los pormenores del deterioro de la falcata $\mathrm{T} 2$, a partir de restos de las capas de alteración desprendidas, se realizan también análisis DRX de la costra de corrosión de la superficie exterior. El objetivo ha sido conocer qué minerales están presentes en la superficie del metal, formando esa costra de alteración que vemos en las imágenes macroscópicas, para que una vez concluya el proceso de restauración hacer una validación por DRX o LIBS de los cambios y transformaciones en algunos puntos de interés de la superficie original de la falcata T2. En las medidas de dos puntos que recogemos en la tabla adjunta [tabla 1], se anotan con detalle estos compuestos, donde hay presencia de derivados del hierro y también de otros propios del contendor geológico, como la calcita, el cuarzo y el óxido de magnesio. Un resultado que se acomoda muy bien a los registros analíticos obtenidos en otras ocasiones en piezas de hierro.

Pero dentro de la mejora del protocolo de análisis hemos procedido a incorporar de manera habitual la técnica LIBS en la caracterización cualitativa de los productos de corrosión antes de la limpieza; el monitoreo continuado con esta técnica de espectrometría según se avanza con la limpieza láser facilita la comprobación por diferencia de intensidades del espectro cuando se ha completado la tarea de restauración de la falcata T2. La rapidez y utilidad de este método de validación de resultados es notable, y si fuese necesario, podría completarse con datos difractométricos.

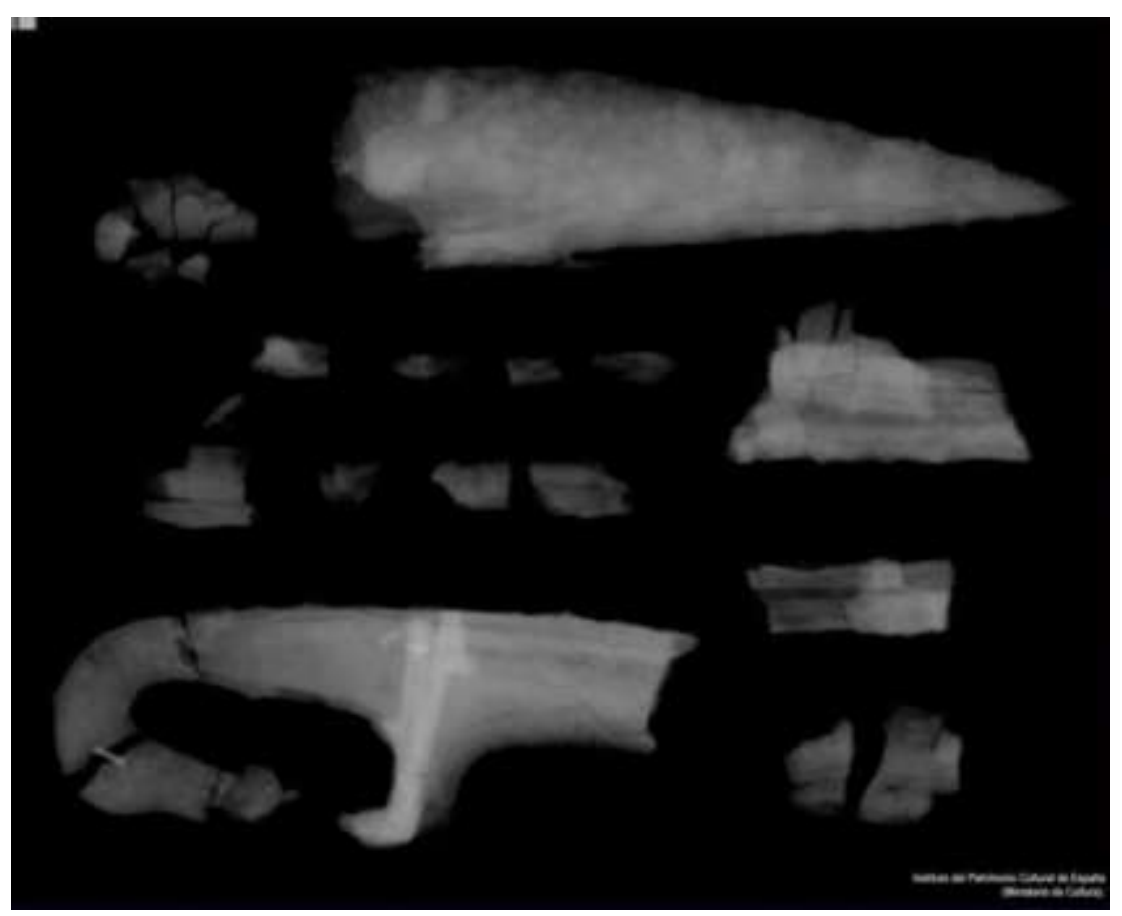

Figura 5. Imagen RX general de todos los elementos de la falcata T2 (Lab. Estudios Físicos. IPCE). 


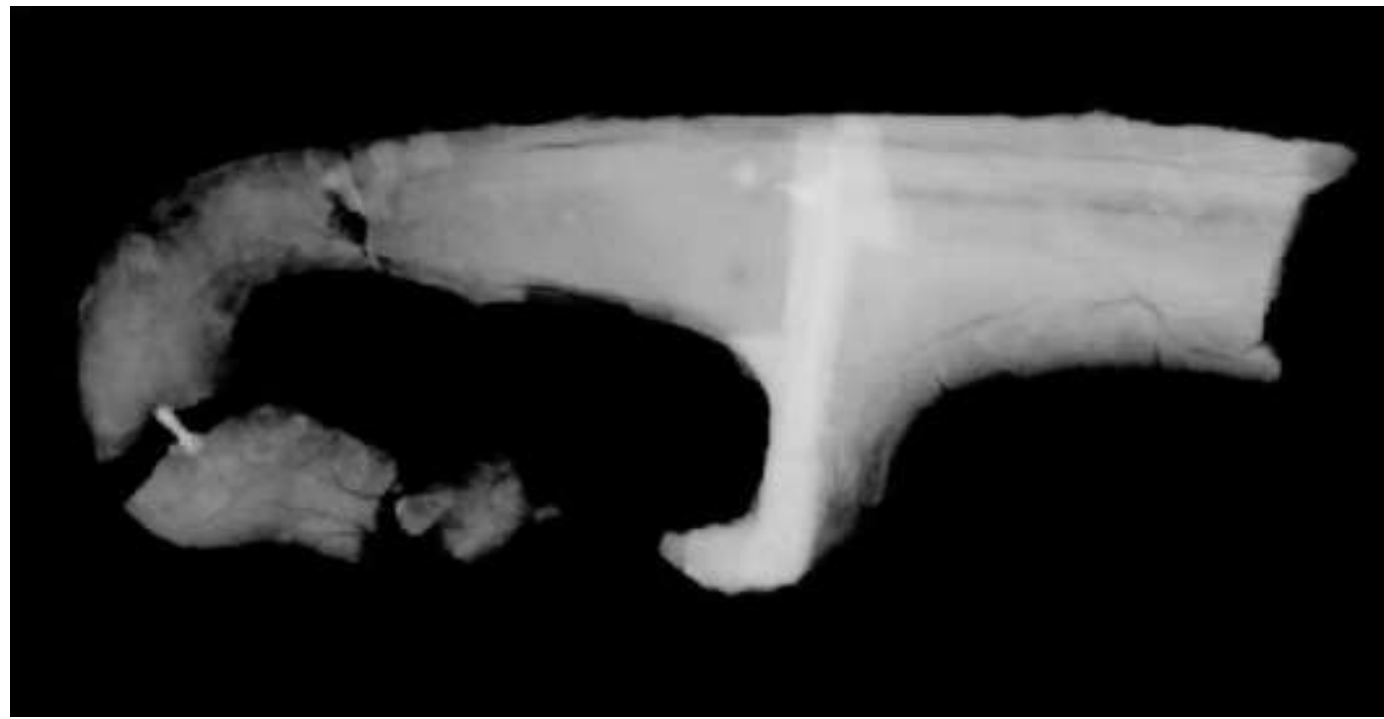

Figura 6. Imagen RX de la empañadura y parte de la hoja donde se aprecia la profunda alteración de la estructura interna y detalles de interés de su tecnología de manufactura (Lab. Estudios Físicos. IPCE).

Tabla 1. Datos DRX de la composición mineral de la superficie de la falcata T2 en dos muestras distintas de la empuñadura y de la hoja.

\begin{tabular}{|l|l|}
\hline $\begin{array}{l}\text { DRX Compuestos antes de } \\
\text { Láser (315.2.a) }\end{array}$ & $\begin{array}{c}\text { DRX Compuestos antes de } \\
\text { Láser (315.1.b) }\end{array}$ \\
\hline $\begin{array}{l}\text { Calcita } \\
\text { Óxido de Magnesio }\end{array}$ & \begin{tabular}{l} 
Brushito \\
\hline Cuarzo
\end{tabular} \\
\hline Hematita & Calcita \\
\hline Goetita & Cxido de Masnesio \\
\hline
\end{tabular}

Los análisis LIBS de los elementos presentes en la costra de alteración permiten ratificar los datos de DRX, sin llegar a ser tan precisos. Hay asimismo una presencia elevada de compuestos minerales con calcio y compuestos de corrosión de hierro. En la imagen [gráfico 1] se ve la superposición de los dos espectros en un punto extremo de la empuñadura y las diferencias que presentan antes y después de la intervención con láser. En el espectro en línea negra destaca con preferencia esa intensa emisión de los canales del calcio, que responden sin duda a la detección de la calcita; tampoco podría descartarse la existencia más residual de algún compuesto de hierro con presencia de calcio, caso de la siderita. Después de someter la falcata a la ablación del láser, se recupera y se aprecia ópticamente una capa homogénea y estéticamente agradable, que corresponde a la pátina de magnetita de la superficie original de la pieza. El segundo espectro en línea roja, tomado cuando se concluye la restauración con el láser de este mismo punto de la empuñadura, muestra una reducción en más del $65 \%$ en los picos de emisión del calcio; una respuesta acorde con la eliminación de la calcita de la capa de corrosión de la superficie. Y en consonancia un considerable aumento en todos los canales de emisión del hierro. Teniendo en cuenta otros datos analíticos 
registrados por nuestro grupo en hierros arqueológicos de condiciones similares (Barrio et al. 2012b), cabe interpretarse por la presencia de minerales estables de hierro, como la magnetita. Esta evaluación se corrobora ópticamente por el aspecto que ha recuperado la superficie original de la falcata.

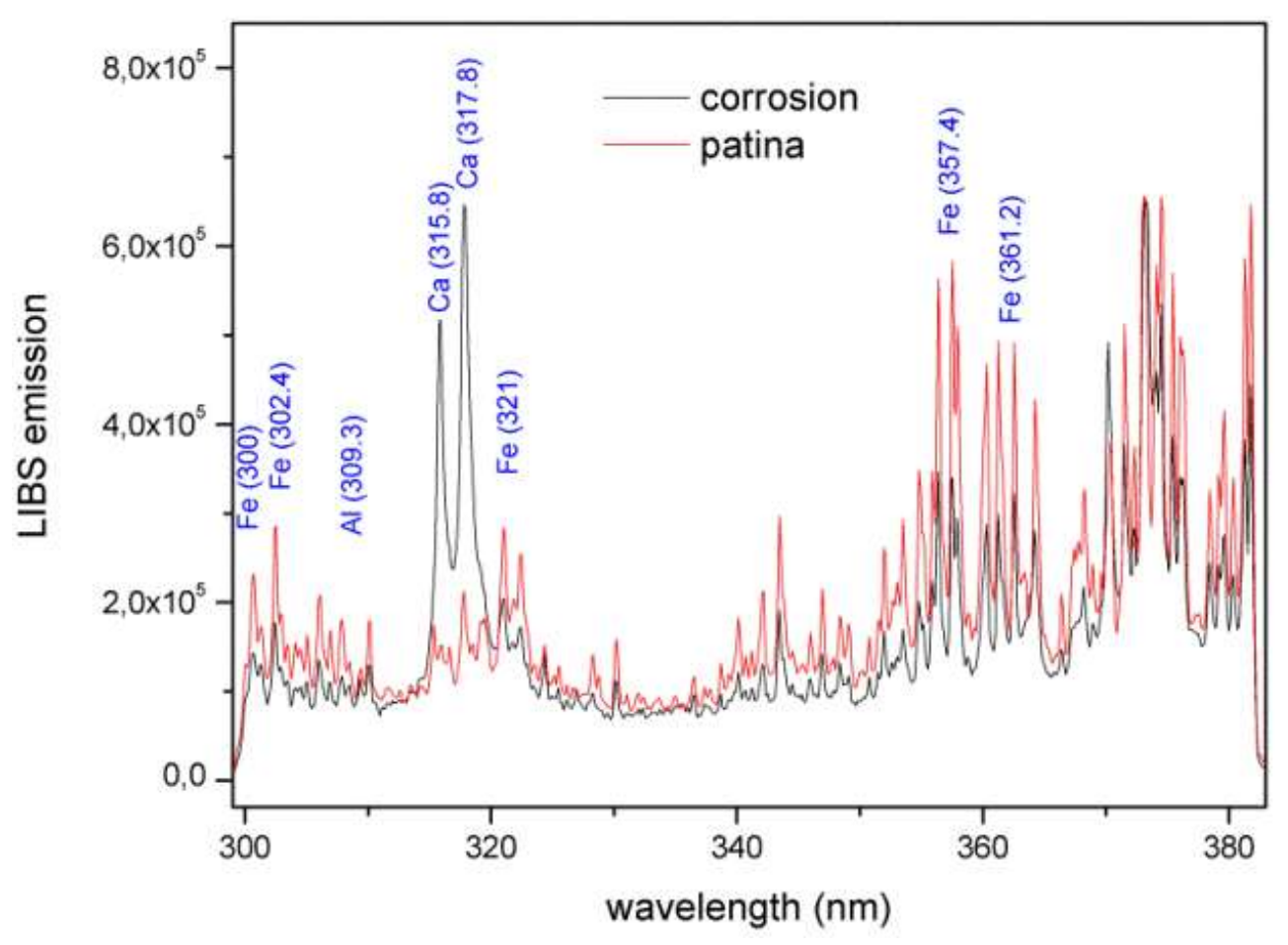

Gráfico 1. Espectros de LIBS de la zona final de la empuñadura para evaluación de efectos de la limpieza láser; en negro los elementos y su intensidad antes del láser y en rojo después del láser donde se aprecia la fuerte eliminación de los compuestos de Ca y el predominio ahora de Fe.

En la ejecución concreta de la restauración de la falcata T2 se han combinado técnicas mecánicas, espátula ultrasónica y láser; responde a un protocolo que ha dado buenos resultados en otros casos dentro de esto proyectos. En primera instancia, se debieron retirar los engasados de la consolidación in situ pero evitando el levantamiento y desubicación de las láminas de la superficie original desprendidas; y ello, en atención al principio de autenticidad [figura 7]. En esta tarea fue muy útil la intervención con láser en parámetros de muy baja intensidad para eliminar los restos del consolidante nitrocelulósico amalgamado con tierras.

La espátula ultrasónica hace posible que las placas de corrosión más superficiales puedan saltar; en todo momento se ha controlado el impacto de las vibraciones para evitar nuevas fisuras.

Para retirar la capa de productos de alteración asentada directamente sobre la pátina se actúa con el láser, intentando combinar los efectos mecánicos con los fototérmicos. Como se evidencia en la [figura 8], es necesario realizar dos etapas de limpieza, en condiciones de trabajo distintas, para conseguir recuperar la superficie homogénea de magnetita (Dickmann et al. 2001, 2005). Es una intervención mínima que no ha querido ir más allá. Entre una y otra etapa se retiraban 
mecánicamente los residuos dejados por el láser, especialmente cuando la película ablacionada compuestas de restos de óxido de silicio no dejada avanzar en la restauración. El resultado conseguido en la recuperación de la pátina es muy bueno, pero irregular, pues en algunas áreas habían desaparecido esa capa original. Y así lo hemos visto confirmado no sólo con procedimiento óptico microscópico sino mediante los análisis LIBS recogidos en la gráfica 1.

Se utiliza el siguiente equipo propio del SECYR:

EOS 1000 SFR (Nd.YAG 1064 de longitud de onda, duración pulso 60-120 microsegundos).

Los parámetros concretos de trabajo han sido éstos:

1a etapa: Energía 450mJ; Spot 4mm; Frecuencia $6 \mathrm{~Hz}$; Fluencia 3,6 Jcm²

2a etapa: Energía 350mJ; Spot 4mm; Frecuencia $4 \mathrm{~Hz}$; Fluencia 2,8 Jcm²

Otros autores desde planteamientos metodológicos algo distintos, han experimentado con láseres de diferente configuración a éste, obteniendo resultados satisfactorios, aunque en hierros históricos o arqueológicos que aún tenían existencia de núcleo metálico (Sook Koh y Sáraday 2003; Sook Koh 2006: 23-28; 45-60).

Para recuperar la autenticidad perdida y devolver carácter documental que tuvo la falcata $T 2$ ha sido necesario lograr su completa legibilidad mediante la integración de los numerosos fragmentos en que había llegado al SECYR. También se han asentado todas las láminas superficiales desprendidas. Para validar la restauración hemos realizado un control higrométrico en campana a fin de comprobar que la corrosión no estaba activa en el hierro de la falcata T2 [figura 9]. Se ha unido con resina epoxídica UHU'PLUS con carga de carga de pigmento natural, puesto que muchas de las fracturas eran antiguas y muy deformadas.

Sin embargo, esta completa lectura de la pieza sólo se ha conseguido cuando se han reintegrado las lagunas que tenía la falcata $\mathrm{T} 2$ en su zona media; se trataba no sólo de una reintegración estética e histórica sino consolidante, pues daba garantías de estabilidad mecánica y seguridad en el manejo de la pieza para su posterior estudio por el equipo de arqueólogos. Se ha utilizado BALSITE $W^{\circ}$, una resina epoxídica tipo madera que se ha entonado de color. El proceso seguido de integración y reintegración de las lagunas ha sido imprescindible para la devolución de una solidez unitaria a la pieza, haciendo posible una lectura correcta tanto de sus aspectos matéricos y tecnológicos como en lo que supone de documentación arqueohistórica del ritual practicado en esa tumba ibérica; una práctica corroborada con la inutilización mediante doblado de otra de las armas, el soliferrum, de la panoplia del guerrero enterrado en el Túmulo 2 de la necrópolis ibérica de El Salobral [figura 10].

El trabajo se ha finalizado aplicando por impregnación a la superficie, con peligro de desprendimiento debido a su delaminación, una capa de consolidación/protección de Paraloid ${ }^{\oplus}$ al $3 \%$ en Xileno/Acetona 50\%).

A pesar de la notable complejidad del trabajo, la aplicación de técnicas láser en restauración de la falcata $\mathrm{T} 2$ ha conseguido unos resultados extraordinarios, garantizando no sólo la recuperación de la superficie original de la pieza sino generando unos productos bien estables, además de devolver todo su contenido estético e histórico a esta espléndida arma ibérica. 
Principios de conservación en una tecnología de restauración innovadora en el Patrimonio

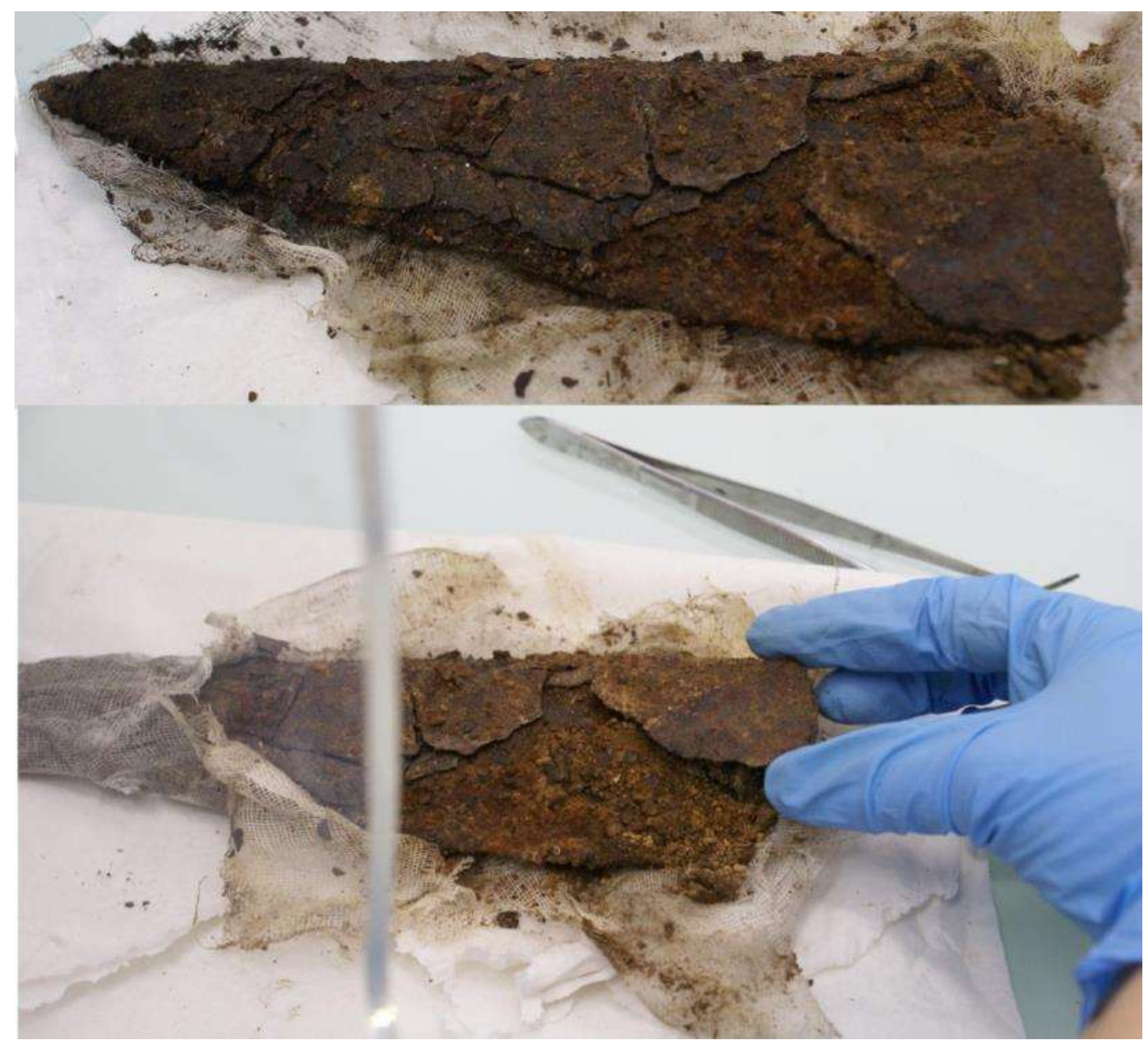

Figura 7. Trabajo complejo de reubicación de las láminas desprendidas de capa superficial de la hoja de la falcata: aspecto general al retirar los engasados (7a), y proceso de colocación en posición original.

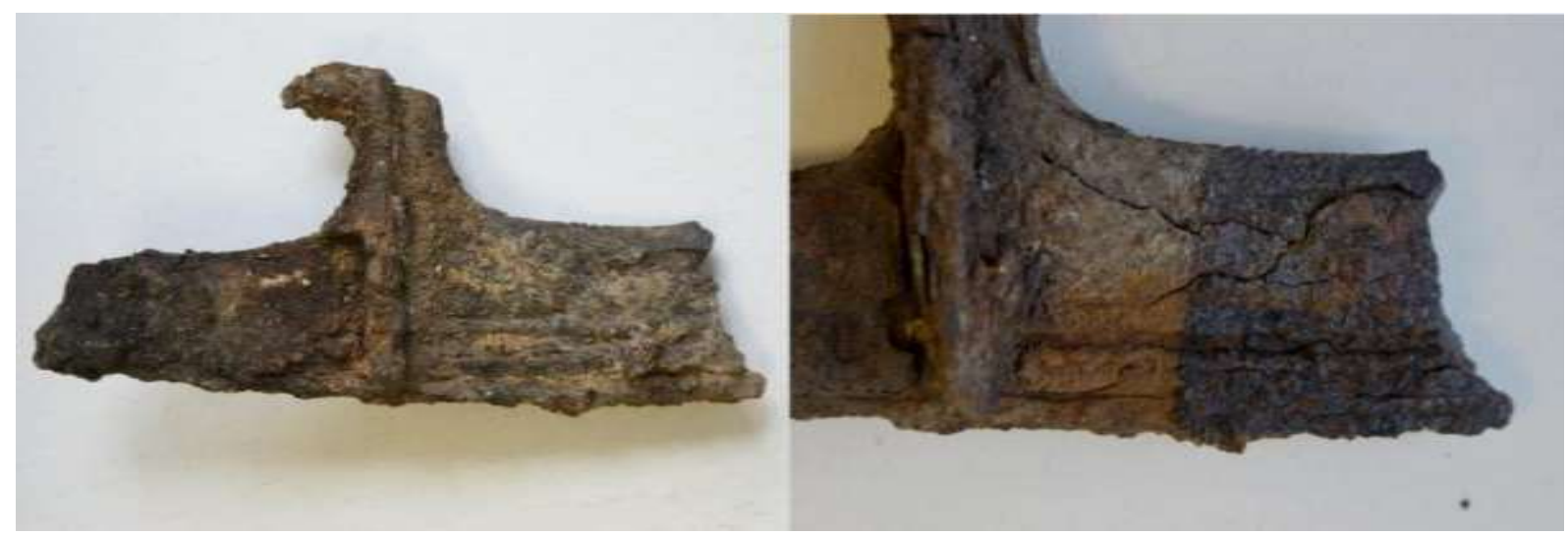

Figura 8. Efecto de la limpieza con láser en la zona de la empuñadura (8a antes de la ablación); nótese la diferencia en la recuperación de la superficie original muy modificada por la total mineralización del hierro (8b). 
Principios de conservación en una tecnología de restauración innovadora en el Patrimonio

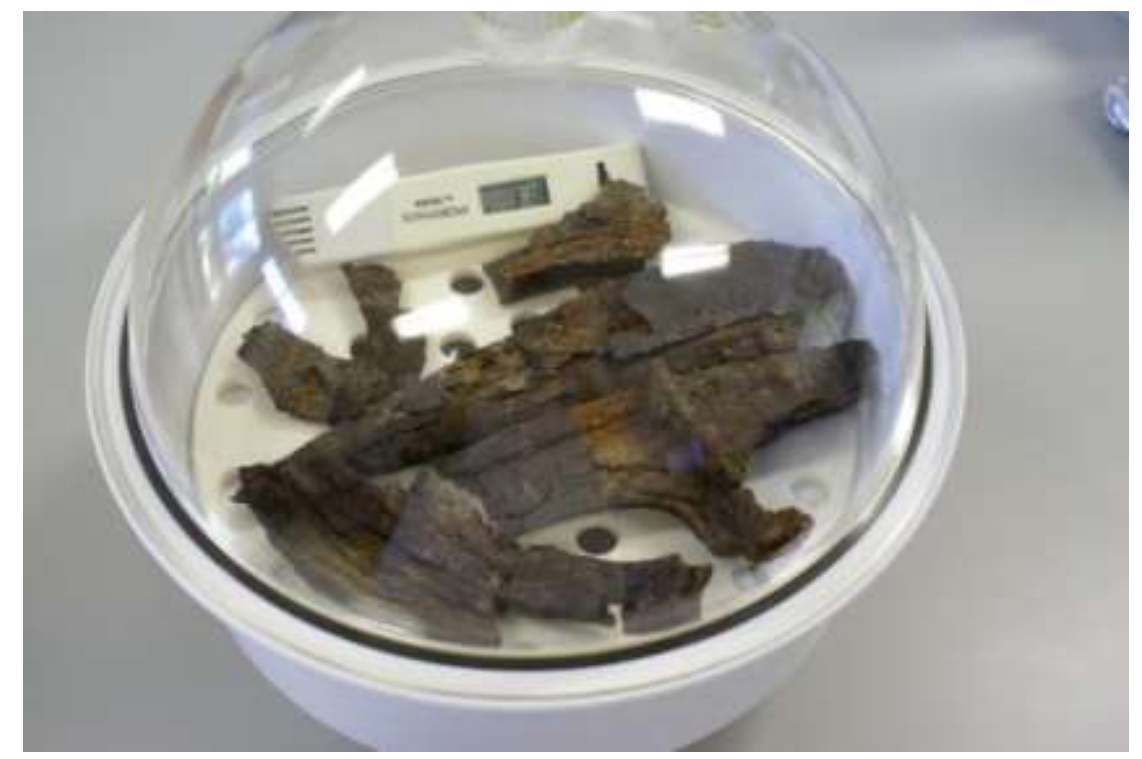

Figura 9. Control higrométrico de la estabilidad de la falcata $\mathrm{T} 2$ durante el proceso de limpieza con láser.

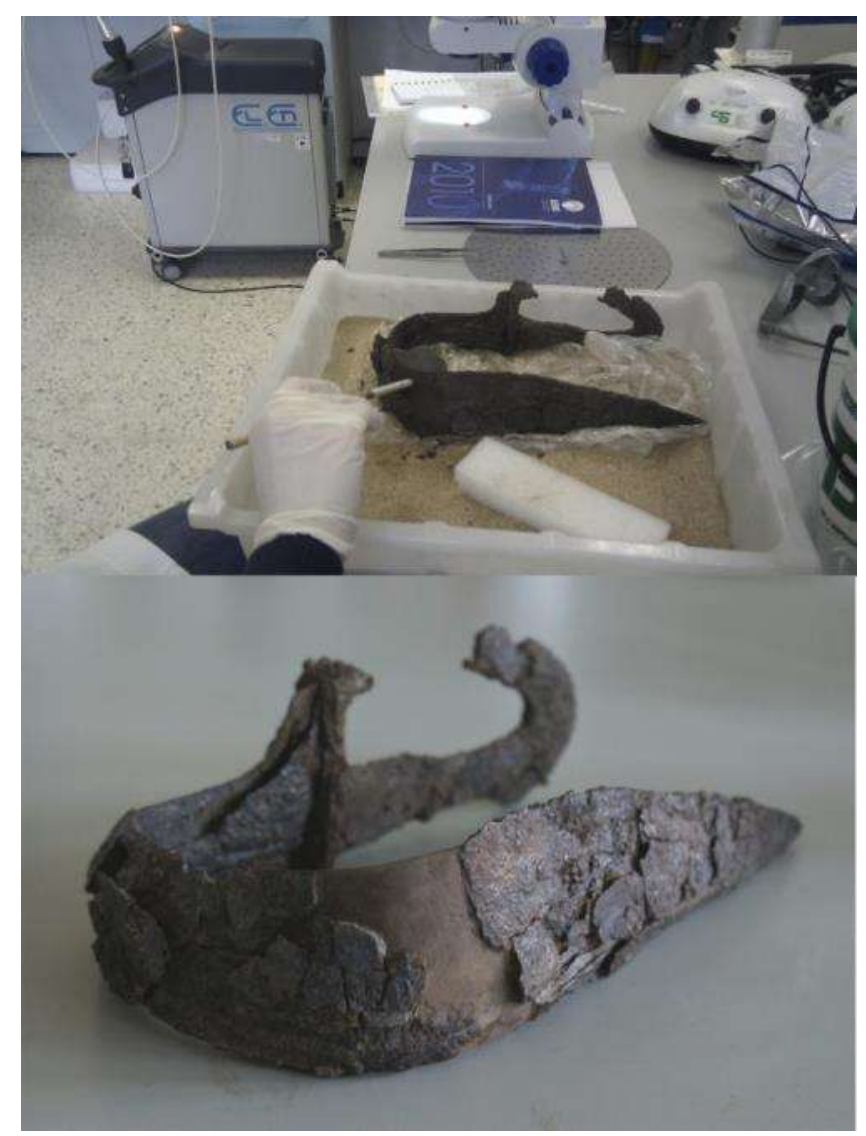

Figura 10. (10a)Proceso de reintegración de lagunas en la zona media de la hoja. (10b) La falcata T2 después de la restauración que he hecho posible su legibilidad estética y arqueohistórica. 


\section{Conclusiones}

La introducción de una nueva tecnología de las características del láser en la restauración de bienes arqueológicos, requiere también su adecuación a las normas que guían nuestra tarea como profesionales del Patrimonio. Unos criterios y principios éticos (en complementación a los principios científicos) que sin ser exhaustivos marcan con acierto la implantación de esta técnica en los comienzos del siglo XXI; su aceptación parece bastante consolidada entre los restauradores, conservadores de Museos y arqueólogos. La llegada de un procedimiento innovador siempre lleva aparejado riesgos en la intervención de los objetos, y más si estos presentan problemas delicados. Por eso es importante establecer un Protocolo de Trabajo que se ajuste a estos principios de la conservación científica definidos en las Cartas de Restauración y en las Directrices de ICOM-CC.

La restauración de la falcata ibérica del Túmulo 2 de la necrópolis de El Salobral completada dentro del Proyecto ARQUEOLÁSER me ha servido de caso práctico para aplicar y mostrar la implantación de esta técnica de innovación, con la que hemos obtenido unos resultados muy positivos. Y hacerlo, estableciendo en cada fase del PT la pauta de ejecución a la vista de los criterios éticos de conservación, y teniendo en cuenta los principios científico-técnicos. Una tarea en la que debemos seguir insistiendo en las restauraciones futuras de objetos arqueológicos para que se transmitan al futuro en las mejores condiciones.

\section{Notas y agradecimientos}

[1] Este trabajo se ha desarrollado dentro de los proyectos i+D "Aplicación de las tecnologías láser en la conservación y restauración de los metales arqueológicos" (HAR2008-05175/HIST. MICINN) "El Láser como herramienta tecnológica en conservación-restauración del patrimonio arqueológico" (CEMU 003. UAM 2012).

[2] Nuestro agradecimiento tanto al Profesor Juan BLánquez, quien llevo a cabo la excavación de esta extraordinaria necrópolis ibérica de El Salobral, como a la directora del Museo de Albacete, Dña. Rubí Sanz Gamo y a la conservadora Dña. Blanca Gamo, que han tenido la amabilidad de hacer préstamo de los materiales metálicos del Túmulo 2 para su investigación y restauración en el marco de los referidos Proyectos.

[3] En la intervención e investigación de la esta pieza (SECYR 315 y 316) han participado, además de yo mismo, los Técnicos del SECYR contratados en ese momento Dña. Elena Catalán Mézquiriz y la Dra. Carolina Gutiérrez Neila. A ellas mi reconocimiento y gratitud.

[4] La Radiografía de la falcata se ha realizado en el Laboratorio de Estudios Físicos del IPCE. Nuestro agradecimiento a los técnicos T. Antelo y M. Bueso.

\section{Bibliografía}

APPELBAUM, B. (1987). "Criteria for treatment: reversibility", Journal of the American Institute for Conservation, 26-2: 65-73.

BARRIO, J. y HERMANA, F. (1998). "Méthode de conservation et restauration d'une Falcata lbérique de la Nécropole de El Salobral (Albacete, Espagne)", en Mourey, W. y Robbiola, L. (eds.) Proceedings of The International Conference on Metal Conservation, METAL 98, ICOM-CC. Draguignan, France. London: Ed. James \& James, 176-184.

BARRIO, J., ARROYO, M., CHAMÓN, J., PARDO, A. I., CRIADO, A. (2006). “Laser cleaning of archaeological metal objects", Heritage, Weathering and Conservation. Ed. Taylor \& Francis Group, London, Vol II: 699-707. 
BARRIO, J., CATALÁN, E., GUTIÉRREZ, P.C., MEDINA, MaC., SANZ, C. (2012a). "Reexcavar la tumba 158 de la necrópolis vaccea de Las Ruedas de Pintia (Peñafiel, VA): Aplicaciones de técnicas láser en la restauración de la panoplia". Vaccea Annuario 5. 2011:70-74.

BARRIO, J., MEDINA, MaC., CID J.P., PARDO, A.I. TURÉGANO, M. (2012b): "Posibilities of LASER conservation of metal objects from archaeological context". En International Congress Science and Technology for the Conservation of Cultural Heritage. 2-5 octubre 2012. Santiago de Compostela. En prensa.

BLÁNQUEZ, J. (1994). "La necrópolis tumular ibérica de El Salobral (Albacete)", Verdolay 6: 199-208.

BERTHOLON, R. (2000). La limite de la surface d'origine des objets métaliques archéologiques.Thèse Doct. Université Paris I. Pantheon-Sorbonne.

BRANDI, C. (1988). Teoría del Restauro. Madrid: Alianza Forma.

CHAMÓN, J., BARRIO, J., E. CATALÁN, M. ARROYO, A. I. PARDO (2007). “Nd:YAG laser cleaning of heavily corroded archaeological iron objects and evaluation of its effects". En LACONA VII, Castillejo \& Moreno \& Ruiz (eds.) London, 297.

CHITTY, W.J., DILLMANN, P., L'HOSTIS, V., LOMBARD, C. (2005). "Long-therm corrosion resistance of metallic reinforcements in concrete. A study of corrosion mechanisms based on archaeological artefacts", Corrosion Science 47: 1555-1581.

DICKMANN, K. HILDENHAGEN, J., STUDER, J., (2001). "Laser removal of corroded layers from archaeological ironwork". En LACONA I, ICOMOS, Paris:Vergés-Belmin, V. (ed.) France, 71-74.

DICKMANN, K. HILDENHAGEN, J., STUDER, J., MUSH, E. (2005). “Archaeological ironwork: removal corrosion layers by Nd:YAG laser". En LACONA V. Berlin: 34-39.

PASIES, T. (2012). "Reconstrucciones desmontables como alternativa reversible en el proceso de reintegración de materiales arqueológicos". GeConservacion 3:117-131.

SOOK KOH, Y. (2006) Laser Cleaning as a Conservation Technique for Corroded Metal Artifacts, Doctoral Thesis, Division of Manufacturing Systems Engineering. Department of Applied Physics and Mechanical Engineering, University of Technology, Luleå, Sweden.

SOOK KOH Y. SÁRADAY, I. (2003). "Cleaning of corroded iron artefacts using pulsed TEA $\mathrm{CO}_{2}$ and Nd:YAGlaser", Journal of Cultural Heritage 4: 129-133.

SIANO, S. (2007): “Principles of Laser Cleaning in Conservation”. En Handbook The Use of Lasers in Conservation and Conservation Science. M. Schreiner, M. Strli (eds.) COST G7.

\section{Documentos técnicos y deontológicos}

ICOM-CC (2006) Código de Deontología del ICOM para los Museos. Asamblea General ICOM en Seúl (Corea).

ICOM (2008). "Terminology to characterize the conservation of tangible cultural heritage". En Triennal meeting (15th), New Delhi: ICOM-CC.

Carta de Atenas 1931.

Carta de Venecia 1964.

Carta del Restauro de Roma de 1972.

Carta del Restauro de Roma 1987.

Carta de Cracovia 2000. 


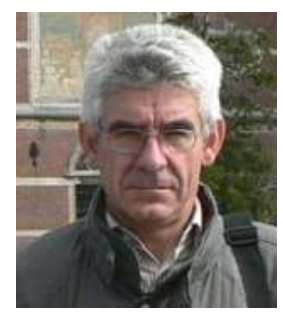

\section{Joaquin Barrio Martín}

joaquin.barrio@uam.es

Catedrático de Arqueología, con especialidad Conservación y Restauración del P. Arqueológico, en el Dpto. de Prehistoria y Arqueología de la UAM. Imparte docencia en cursos de Grado y Postgrado (Máster y Doctorado) de materias relacionadas con la Conservación y Restauración del Patrimonio Arqueológico tanto en la UAM como en otras Universidades, dando como resultado la dirección de Tesis de Máster y de Tesis Doctorales dentro de este campo. La línea de investigación actual con dirección de proyectos de i+D está centrada en la "Aplicación de tecnologías innovadoras en la conservación y restauración del P. Arqueológico", y ha dado lugar a la publicación de numerosos artículos en revistas nacionales e internacionales, libros, actas de congresos, capítulos de libros e informes técnicos dentro de este ámbito de la conservación y restauración del P. Arqueológico. Miembro de instituciones como el ICOM, GEIIC, AEND, Academia de Historia y Arte de San Quirce,... Así mismo, forma parte de las Comisiones Nacionales de Proyectos i+D y de la Comisión Nacional de Doctorados de Excelencia (Rama de Artes y Humanidades).

Artículo enviado el 18/02/2013

Artículo aceptado el 01/05/2013 
Reseñas 


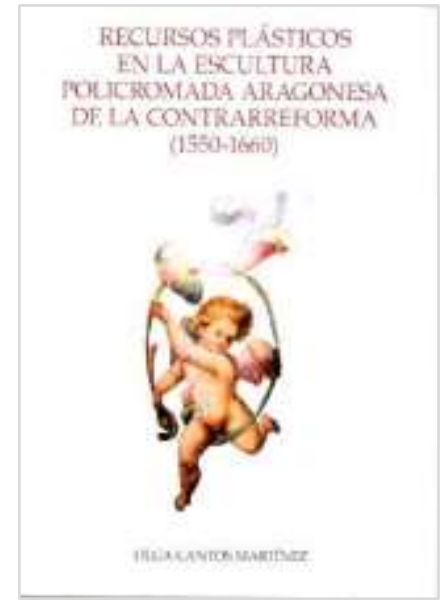

\section{Recursos plásticos en la escultura policromada aragonesa de la contrarreforma (1550-1660)}

\section{Olga Cantos Martínez}

Centro de Estudios Turiasonenses de la Institución "Fernando el Católico" y Fundación Tarazona Monumental. Tarazona 2012. 642 páginas, $235 \mathrm{~mm}$.

ISBN: 978-84-9911-208-4

Esta reciente publicación corresponde a la revisión de la tesis doctoral de Olga Cantos defendida en la Universidad Complutense de Madrid el 28 de junio de 2012. Se trata de un proyecto de investigación desarrollado por la autora a partir de las intervenciones de conservación y restauración realizadas en un conjunto de retablos aragoneses y que compensa el vacio documental existente sobre el tema. Son obras contrarreformistas datadas entre los años 1550 y 1660 al amparo de las nuevas pautas doctrinales que la Iglesia Católica puso a punto para atender a los dictados del Concilio de Trento (1545-1563), y que llegan a España desde Italia bien entrado el siglo XVII "propiciando el redescubrimiento de las artes del color y el análisis plástico y estético de las mismas". La dilata trayectoria profesional de Olga como restauradora especializada en escultura policromada del Instituto del Patrimonio Cultural de España del Ministerio de Educación, Cultura y Deporte le ha permitido aunar su vocación de investigadora al conocimiento de las técnicas y los materiales que permite la práctica de la restauración y es justamente la conjunción de ambas visiones lo que le confiere a este trabajo su enorme interés.

Entre las obras estudiadas destacamos el retablo mayor de la Catedral y el de la iglesia de San Francisco de Tarazona, el retablo mayor de Almudévar, el de la parroquia de Ólvega, el retablo mayor de Ateca, el de la parroquia de Monterde y el de la Colegiata de Santa María en Calatayud.

El texto se estructura en ocho capítulos, precedidos de un prólogo del historiador Jesús Criado Mainar, uno de los directores del trabajo, y una introducción al tema por parte de la autora. Como complemento de gran utilidad se incluye un glosario de términos y expresiones artísticas y una exhaustiva bibliografía y webgrafía.

En el Capítulo 1 titulado "La contrarreforma. Trento y el significado del decoro" se analiza el impacto ocasionado por la reforma protestante surgida en Europa occidental en el primer cuarto del siglo XVI, promovida por el teólogo Martín Lutero, y la reacción de la Iglesia Católica ante las nuevas ideas, que conduce a la celebración de un Concilio General en la ciudad de Trento, convocado por el papa Pablo III. A partir de entonces la policromía contrarreformista fue canalizada hacia las ideas de pureza emanadas del concepto de la verdad, el decoro, el orden y la búsqueda del natural en las figuras, con un programa iconográfico propio. 
El Capítulo 2 se dedica a la "Organización perceptiva en los retablos escultóricos", describiendo la percepción física de la forma en la imaginería y las tallas decorativas, los dibujos, las fuentes gráficas y modelos, el concepto de proporción, simetría y estudio anatómico, las técnicas de talla y las precisas indicaciones que se daban para la ejecución de las obras. En la descripción de la percepción física del color se explica el interés que los artistas y tratadistas muestran por las luces y las sombras, los diferentes recursos técnicos empleados para la percepción de los relieves (el sombreado esgrafiado, el modelado tonal, el modelado cromático de las carnaciones), la influencia del tipo de perspectiva, así como la incidencia de la fuente de iluminación, del estado de conservación y de la posición del observador en la apreciación de las obras.

El Capítulo 3 aborda las "Características de la policromía contrarreformista" describiendo el color y el colorido a nivel conceptual, las funciones atribuidas a los recubrimientos cromáticos de este período, tanto de tipo emotivo como descriptivo, estético y protector. Se desarrollan ampliamente las distintas técnicas de ejecución utilizadas para la preparación del soporte, el aparejado y el proceso del dorado, así como los materiales empleados en la pintura, incluyendo el encarnado y la relación de pigmentos y aglutinantes.

El Capítulo 4 desarrolla "Las técnicas del estofado", comenzando con una relación de las referencias documentales, la evolución de la técnica a lo largo del tiempo, las diferentes variantes de los motivos incisos esgrafiados y pintados, tanto a nivel tecnológico como estilístico. Los estofados esgrafiados permitían reproducir las texturas de los bordados y tejidos más lujosos, mientras que los realizados a pincel servían para representar los adornos de tipo figurativo y naturalista.

No obstante, destaca el estudio de las dos técnicas pictóricas más destacadas de la policromía del siglo XVII, la de las aguadas de colores, una evolución de las grisallas a favor de las monocromías cromáticas (Capítulo 5: "Pinturas monócromas"), y la de los paños cambiantes, procedente del norte de Italia (Capítulo 6: "La técnica de los paños cambiantes"). Un análisis detallado en relación con las combinaciones de los cambiantes ha permitido determinar los contrastes más utilizados según la cronología, el procedimiento pictórico o las descripciones de los tratadistas. Dada la repercusión de esta técnica se describen sus dos variantes tecnológicas: bañados y yuxtapuestos.

En el Capítulo 7 dedicado al "Repertorio decorativo" se pone de relieve la importancia de la búsqueda del natural a través del modelado pictórico y de los efectos perspectiva a través de los lexos pictóricos, ejecutados en todos los casos con gran detalle y sutileza de matices. Una parte importante de las decoraciones recayó en este período histórico en los diseños textiles, que debían responder a las demandas del decoro que exigía un decente atavío, siempre conforme a la condición de cada personaje. El trabajo explica la importancia simbólica del color en la indumentaria, determinando los diferentes tipos de prendas de vestir.

El Capítulo 8 sobre las "Carnaciones" describe las diferencias entre los acabados mates y al pulimento, así como las fases del proceso pictórico requerido para imitar el aspecto de la piel.

Como conclusión de esta reseña queremos destacar el rigor e interés de este trabajo de investigación, que contribuye a profundizar en el conocimiento de las obras retablísticas de este período en Aragón, tanto desde el punto de vista histórico artístico como de las técnicas y los 
materiales. Se pone además en evidencia cómo el acercamiento a las obras que permiten los proyectos de conservación y restauración puede contribuir de forma notable al estudio de la historia del arte. Es necesario también resaltar la gran calidad de las imágenes que ilustran el texto, realizadas por la propia autora.

Ana Laborde Marqueze Instituto del Patrimonio Cultural de España 


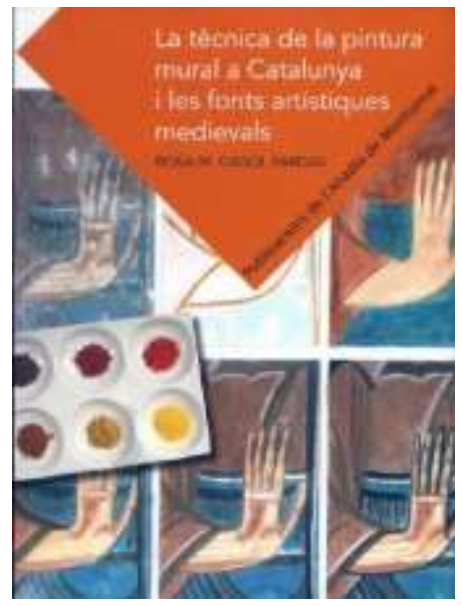

\section{La técnica de la pintura mural a Catalunya $i$ les fonts artístiques} medievals

\section{Rosa M. Gasols Fargas}

Barcelona, Publicacions de l'Abadia de Montserrat, 2012.

189 páginas, $220 \mathrm{~mm}$.

ISBN: $978-84-9883-552-6$

Esta publicación es el resultado de la tesis doctoral presentada el año 2006 por Rosa M. Gasols Fargas en la Facultad de Bellas Artes de la Universidad de Barcelona, titulada "La Pintura Mural Romànica. Estudi de la Tècnica i Anàlisi dels Materials". Se trata de una magnífica síntesis del conocimiento que se tiene hasta ahora sobre la técnica de la pintura mural medieval en Cataluña, con algunas aportaciones interesantes derivadas de su investigación respecto a materiales utilizados y sus conexiones con otras escuelas de pintura mural europeas.

Como indica la autora en la introducción del libro, su metodología ha consistido, por un lado, en la revisión y análisis de textos históricos fundamentales que contienen descripciones sobre la técnica, procedimientos y materiales de la pintura mural medieval, como son los tratados del monje Theophilus, de Eraclius, el Mappae Clavícula ... , y por otro lado el estudio directo de una serie de conjuntos medievales catalanes, con un examen preliminar in situ de la pintura y un análisis físicoquímico de los materiales constitutivos.

Estructura la obra en cuatro grandes capítulos. En el primero revisa las fuentes de tecnología artística medieval más importantes, en las que se pueden encontrar referencias fundamentales a las distintas prácticas y materiales utilizados en la pintura mural de distintos ámbitos europeos y cronologías: Mappae Clavícula, "De coloribus et artibus romanorum" (Eraclius), "Schedula diversarium artium" (Theophilus), Petrus de Sant Audemar y el Manuscrito Sloane. De cada texto extrae la información contenida sobre los pigmentos, aglutinantes, mezclas de colores y sistema de construcción de la pintura, barnices, capas de preparación y soportes. Previamente ofrece una muy útil síntesis de los pigmentos y colorantes utilizados en época medieval, sus composiciones y distintas denominaciones según los textos, así como de las recomendaciones para la construcción de tonos que hacen los distintos autores.

En el segundo capítulo, también introductorio, aporta una visión general de la pintura mural en Cataluña y Aragón y una descripción, desde diferentes ángulos, de las obras seleccionadas para el estudio. Comienza justificando los criterios de selección que le han llevado a determinar los conjuntos a estudiar: cronología, ubicación geográfica y estado de conservación in situ. Las obras estudiadas son el retablo mural prerrománico de Sant Pere de Terrassa; el ábside de Sant Serni de Baiasca y los fragmentos in situ de Sant Climent de Taüll, del siglo XIl; y la sala capitular de Santa Maria de Sixena, de alrededor de 1200. De ellas hace una síntesis de su marco histórico y artístico, 
una descripción formal, iconográfica y estilística, la historia material de la obra, restauraciones sufridas y estado de conservación actual.

Creo interesante resaltar su observación, al comienzo de este capítulo, sobre la restricciones a la hora de estudiar las obras in situ; en efecto, una situación muy común que se debe a las dificultad física de acceder a las obras y a la necesidad de obtener permisos lo que normalmente limita las posibilidades de estudio a las oportunidades brindadas por los proyectos de restauración.

El capítulo III, tras referir con detalle la metodología de investigación científica empleada y el concepto de la pintura mural con sus términos técnicos más frecuentes, ofrece una descripción muy completa de la técnica utilizada en cada uno de los ejemplos: el soporte arquitectónico (características del muro), los revestimientos de preparación, las jornadas de trabajo, las técnicas de trasferencia del dibujo preparatorio, pigmentos y aglutinantes identificados, la construcción de la pintura, enriquecimientos decorativos (orlas, cenefas, motivos en relieve...), otras materias superficiales.

En el último describe las conexiones técnicas dé cada uno de estos conjuntos con otras obras catalanas estudiadas, con escuelas pictóricas europeas y con las fuentes históricas consultadas, para terminar con unas conclusiones en las que, de manera sintética, expone los resultados comparativos del capítulo anterior.

Como afirma la autora en sus conclusiones finales, estudios como este contribuyen a la construcción de un corpus de la pintura mural catalana, algo que todavía queda por hacer para el conocimiento de este riquísimo y singular patrimonio. Este objetivo será más cercano a medida que se vayan publicando estudios parciales provenientes de proyectos de conservación o de investigación, entre los que el trabajo de Rosa M. Gasol constituye un magnífico referente.

Rocío Bruquetas Galán Instituto del Patrimonio Cultural de España 


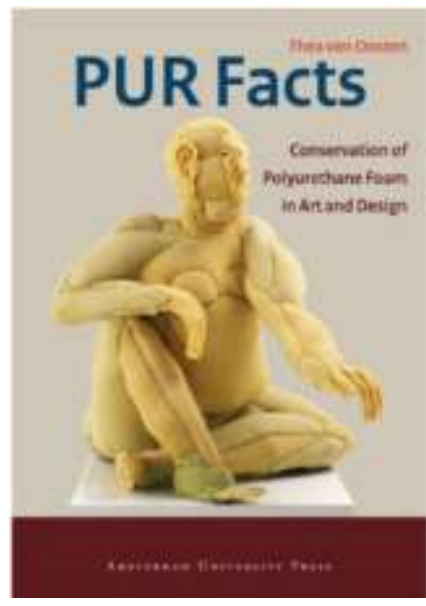

PUR Facts. Conservation of Polyurethane Foam in Art and Design

\section{Thea van Osten}

Amsterdam University Press

Amsterdam, 2011

128 páginas, ilustraciones en color y blanco y negro, $170 \times 240 \mathrm{~mm}$, pasta blanda.

ISBN: 978-90-8964-210-3

Las publicaciones relacionadas con los nuevos materiales, su empleo en la ejecución de obras de arte y objetos de diseño, junto con los problemas asociados a su conservación son siempre de interés. Este es el caso del libro "PUR Facts. Conservation of Polyurethane Foam in Art and Design" escrito por Thea van Osten, y que, como indica su título, se centra en el uso de las espumas de poliuretano en el contexto del arte y el diseño y la conservación de las obras realizadas con este material.

Desde hace décadas, las espumas de poliuretano (PUR) forman parte de nuestra vida diaria y el desarrollo de los procesos químicos y las tecnologías asociadas a su procesado, han puesto en el mercado una gran variedad de productos con aplicaciones en construcción, embalaje, transporte, textiles, diseño industrial y también en el arte. En la actualidad son muchos los museos de arte contemporáneo que, entre sus colecciones, conservas piezas realizadas en espumas de poliuretano flexible (PUR), material que fue diseñado para usos en los que no era necesaria su durabilidad. Sin embargo, como es sabido, se trata de una sustancia muy inestable que resulta muy sensible a los fenómenos de foto-oxidación, responsables de su acusada degradación que frecuentemente tiene como consecuencia la completa destrucción del objeto. Esta circunstancia es responsable de que, en los museos de arte contemporáneo, se deban abordar trabajos de restauración de obras realizadas con este material en los que resulta complejo encontrar las soluciones más eficaces $y$, además, siempre es necesario establecer estrategias muy controladas para favorecer su conservación.

Todas estas cuestiones son abordadas en este libro, en el que se recogen las investigaciones realizadas por Thea van Oosten en el Netherlands Institute for Cultural Heritage (ICN), recientemente fusionado con el Cultural Heritage Agency of the Netherlands (RCE). Estas investigaciones se llevaron a cabo dentro del marco del proyecto de investigación interdisciplinar PUR Research Project, que contó con la colaboración de Aleth Lorne y Olivier Béringuer, y en el que se abordó la restauración de diferentes piezas realizadas en espuma de poliuretano. Como consecuencia de este punto de partida, este libro está dirigido a conservadores, restauradores, conservadores científicos, coleccionistas y, por supuesto, también los artistas y diseñadores que muestren preocupación en la durabilidad de los materiales que utilizan en la ejecución de sus 
obras. Debido al amplio espectro de profesionales al que puede interesar, a lo largo de sus seis capítulos se tratan diferentes temas que, en mayor o menos medida, serán de utilidad para cualquiera de los tipos de lectores indicados.

El Capítulo, 1 titulado "Polyurethanes, manufacture and applications", se inicia definiendo este tipo de polímeros, su composición, estructura y propiedades generales, todo ello acompañado de una breve revisión de sus procesos de fabricación. En este mismo capítulo se describen sus diferentes variedades tanto a nivel de composición (poliéter uretano y poliéster uretano), como de su comportamiento mecánico (termoplásticos, termoestables y elastómeros), además de sus posibles usos como adhesivos, fibras, espumas flexibles y rígidas. Finalmente se incluyen unos breves apartados relacionados con el uso de diferentes tipos de poliuretano en la obtención de objetos mediante moldeo por inyección, sus aplicaciones en la obtención de recubrimientos de acabado o protección de superficies y su empleo en la ejecución de obras de arte.

En el Capítulo 2 "Chemistry, properties and degradatio", se profundiza en algunas de las cuestiones ya planteadas en el capítulo anterior, especialmente las relacionadas con su composición química, las reacciones químicas asociadas a su síntesis y la naturaleza química de las sustancias de partida. De manera clara y concisa describe la distintas etapas de reacción asociadas al proceso de espumado, crecimiento de la cadena y procesos de entrecruzamiento. Dedica un interesante apartado a las espumas de poliéter uretano y de poliéster uretano en el que su describen sus proceso de obtención, los diferentes tipos de sustancias de partida utilizadas en cada caso, tipos de catalizadores y otros componentes, tales como agentes de espumado, extendedores de cadena y otros aditivos. El último apartado está dedicado a los factores responsables de la degradación del poliuretano, haciendo referencia a los relacionados con su composición y los referidos a las condiciones ambientales.

El Capítulo 3 "History of polyurethane foam conservation" contiene una revisión de los tratamientos y los productos utilizados en los procesos de conservación-restauración de diferentes obras realizadas con espumas de poliuretano. El período histórico revisado comprende desde 1990 hasta 2009 y los tratamientos aplicados han sido de consolidación. En todos los casos se describen brevemente los procesos y los resultados obtenidos.

En el Capítulo 4 "Ageing behaviour of polyurethane foam" se recogen los resultados de las investigaciones realizadas en torno a los procesos de envejecimiento de las espumas de poliuretano (polieter uretano y poliéster uretano). Su planteamiento es fundamentalmente experimental y en él se describe la metodología seguida respecto a la selección de materiales, preparación de muestras, técnicas analíticas utilizadas, ensayos realizados y condiciones de envejecimiento artificial aplicadas. El interés de la información expuesta se enriquece al incluir el estudio de una serie de consolidantes de uso habitual en el tratamiento obras artísticas realizadas en espumas de poliuretano.

La evidente inestabilidad de estas espumas, con su consiguiente amarilleamiento, pérdida de resistencia y resilencia, aumento de rigidez y disgregación de su estructura, hacen irremediablemente necesario proceder a su consolidación. Teniendo en cuenta esta realidad, en el 
Capítulo 5 "Assessing the condition of polyurethane foam" se dan una serie de pautas de gran utilidad para conocer el tipo de espuma constitutiva de la pieza que se debe conservar y evaluar su estado de conservación. Estas pautas se apoyan tanto en métodos empíricos como científicos. En el último apartado de este mismo capítulo se dan algunas instrucciones referidas a los tratamientos de consolidación aplicables a espumas de polieter uretano nuevas y envejecidas, explicando los productos utilizados, su preparación y su forma de aplicación.

En el Capítulo 6 "Case studies" se describen en detalle los proyectos de intervención realizados por Aleth Lorne sobre la obra Zuccaia (1991) en el ICN en el año 2007 y por Barbara Ferriani sobre la obra Sassi (1972) en Milan (Conservation Studio) en el año 2009. Ambas son de mismo autor, están realizadas en espuma de poliuretano y presentaban los deterioros característicos de este material. De manera muy ilustrativa y detallada se describen los métodos y materiales aplicados en relación con el significado y la función original de ambas obras y su integridad física.

Para terminar, la autora incluye un glosario de términos, que resulta de ayuda para los lectores que no tengan formación científica y una interesante bibliografía relacionada con los temas tratados en el libro.

Como resumen de lo comentado en los párrafos anteriores, hay que señalar que la lectura de este libro es muy recomendable para los profesionales que deben abordar las tareas de conservación y restauración de obras de arte y objetos de diseño realizados con poliuretano, no solo por la información práctica que contiene, sino también por las pautas metodológicas que plantea para llevar a cabo una investigación sistemática sobre tratamientos de restauración.

Margarita San Andrés Moya Universidad Complutense de Madrid 


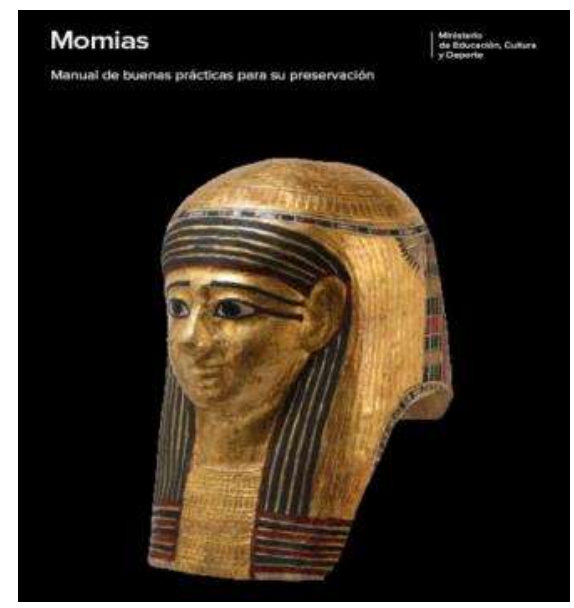

Momias. Manual de buenas prácticas para su preservación

Coordinación Científica: Nieves Valentín y María García

Ministerio de Educación, Cultura y Deporte. Secretaría General

Técnica. Subdirección General de Documentación y

Publicaciones. Madrid, 2012.

236 páginas, $230 \times 280 \mathrm{~mm}$.

ISBN 978-84-8181-524-5

Aunque este libro aborda el tema de las momias, su conocimiento, conservación y preservación, y por lo tanto podría parecer una publicación muy específica y limitada en cuanto a posibles interesados, hay que decir que constituye, además, un manual de buenas prácticas para muchos otros objetos de naturaleza orgánica. Por lo que puede ser recomendable su lectura para conservadores-restauradores, arqueólogos e historiadores.

Se contemplan en el mismo todos los problemas asociados a las momias de diferentes culturas (egipcias, guanches y americanas), desde los aspectos éticos y legales, hasta las intervenciones de conservación curativa, su exposición y divulgación.

La complejidad de esta tipología de bienes culturales deriva también de que se trata de cuerpos que son testimonios de creencias, ritos, religiones y contextos culturales, en los que el patrimonio inmaterial se encuentra asociado de forma fundamental para entender el origen y la razón de ser de estos vestigios.

Las delicadas colecciones de momias, con sus particulares métodos de momificación y enterramiento, rodeadas de numerosos elementos en forma de ajuares funerarios, como textiles y metales entre otros, constituyen, por tanto, un interesante legado cultural con problemas específicos de preservación. Este libro ha logrado establecer los protocolos de actuación deseables en estos casos, basados en las más recientes investigaciones científicas de carácter interdisciplinar, y aporta también propuestas técnicas y metodologías sencillas a la vez que eficaces.

La publicación cuenta con la coordinación científica de Nieves Valentín, bióloga del IPCE, con una gran experiencia en materia de preservación; y María García Morales, conservadora del Cabildo Insular de Tenerife, especializada en los problemas relacionados con las momias guanches.

Se estructura en cinco capítulos: "Contexto histórico y marco legal", "Las momias en el yacimiento", "Las momias en el museo", "Museos singulares. Propuestas para su preservación", y "La difusión". Subdivididos, a su vez, en varios apartados cada uno.

En el primer capítulo, María García e Isabel Herráez - del IPCE- tratan respectivamente la definición de las momias como sujetos o como objetos, los tipos de momificación así como la significación o 
valor que han tenido a través del tiempo; por otro lado, las cuestiones éticas y legales implicadas al tratarse de restos humanos, así como los criterios de exposición.

Soledad Díaz -también del IPCE- aborda la preservación y conservación in situ de restos bioarqueológicos, óseos y momificados, en el segundo capítulo del libro. Analiza los lugares en los que se ubican y sus condiciones, factores de alteración, documentación y tratamientos in situ.

En el capítulo tercero, sobre las momias en el museo, Ruth Rufino -del Cabildo Insular de Tenerifepresenta un apartado dedicado a los métodos de evaluación para el diagnóstico de alteraciones, y otro a la valoración del estado de conservación y la importancia de un buen "chequeo". Nieves Valentín trata del análisis y control del biodeterioro, tan importante en el caso de las momias, así como su tratamiento y erradicación por métodos no tóxicos. Shin Maekawa -especialista en The Getty Conservation Institute- aborda las condiciones ambientales recomendadas, los sistemas de control climático en los museos, y los distintos tipos de vitrinas libre de oxígeno, junto con los compuestos que ocasionan los olores característicos de las momias. María García dedica tres artículos consecutivos a las normas para la manipulación de restos momificados explicando los tipos de soportes y materiales más adecuados para ello; a los fundamentos para el traslado dentro y fuera del museo con los sistemas y materiales de embalaje; y a "Los imprescindibles del almacén de momias". En este último alude al control ambiental, a los sistemas de almacenaje, mantenimiento, seguridad y al plan de protección ante emergencias, incluyendo unas útiles fichas técnicas. Finaliza este capítulo con la aportación de Isabel Herráez sobre las intervenciones de conservación-restauración, con las definiciones del ICOM-CC de Nueva Delhi, los criterios de intervención, un recorrido por algunas intervenciones realizadas en momias y sus consecuencias.

En el capítulo cuarto se tratan los casos de las momias americanas del Museo de América de Madrid, su contexto histórico y estado de conservación, por Carmen Cerezo, Teresa GómezEspinosa y Ana Verde; y el estudio antropológico de los mismos, por Beatriz Robledo. También se da cuenta de la conservación de la Señora de Cao, en Perú, por parte de Arabel Fernández y Régulo Franco.

En el último capítulo, dedicado a la difusión, María Dolores Meneses y Jorge Martín -ambos de la Universidad de La Laguna-, dedican un tema a las "Tecnologías visuales y estrategias comunicativas para difundir el patrimonio. El caso de las momias aumentadas", refiriéndose en este último caso a la tecnología que facilita una mejor visualización.

Toda la publicación se ve enriquecida con fotografías, gráficos, tablas, cuadros e ilustraciones que contribuyen a la buena presentación y mejor comprensión de lo tratado en los textos.

La publicación de este libro estuvo acompañada de otras actividades, como conferencias y cursos (Jornadas Técnicas "Momias. Propuestas para su preservación" organizadas por el IPCE en el Museo de América los días 24, 25, y 26 de junio de 2013). Estas cuestiones atrajeron gran cantidad de público, prueba del gran interés que estas cuestiones despiertan.

Ana Ma Calvo Manuel Universidad Complutense de Madrid 


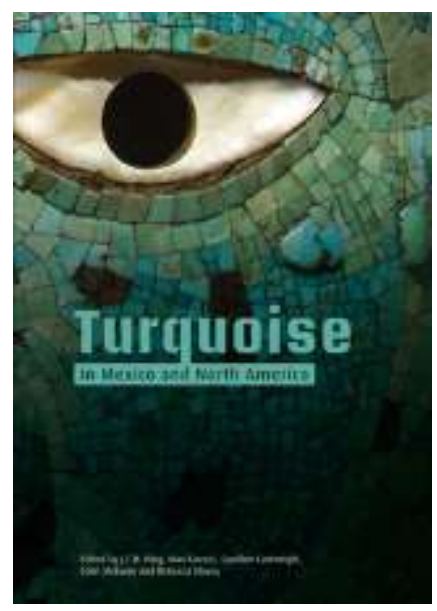

\section{Turquoise in Mexico and North America: Science, Conservation, Culture and Collections}

Editado por J. C. H. King, Max Carocci, Caroline Cartwright, Colin McEwan and Rebeca Stacey

Publicado por Archetype Publications Ltd. Plymouth, 2012.

232 páginas, $297 \times 210 \mathrm{~mm}$.

ISBN: 9781904982791

El libro por editado J. C. H. King, Max Carocci, Caroline Cartwright, Colin McEwan and Rebeca Stacey es una recopilación de la conferencia organizada en diciembre de 2009 en el Museo Británico bajo la denominación "Turquoise, Henry Christy and European Collections". Dicha reunión tuvo lugar durante la exposición de "Moztezuma: Aztec Ruler" para conmemorar el 200 aniversario de la independencia de Méjico en el que se exhibieron algunos de los célebres mosaicos del coleccionista del siglo XIX Henry Christy.

El objetivo de los organizadores de la conferencia a la que se ha dado una denominación en esta publicación más acorde con su contenido "Turquoise in Mexico and North America: Science, Conservation, Culture and Collections" fue fomentar el diálogo y el intercambio de conocimiento entre los estudiosos de una cultura indígena fascinante que empleaba gemas como las turquesas para decorar objetos que formaban parte de sus rituales. En ella se pretendía ahondar a través de las fuentes históricas y científicas en el estudio de los mosaicos y joyas de antiguas civilizaciones de las tribus nativas de Méjico y Norteamérica.

Uno de los puntos más interesantes de esta monografía es la combinación de los conocimientos académicos con las fuentes de la cultura popular. En los capítulos introductorios se establece la problemática general de los objetos patrimoniales que contienen turquesas como piedras ornamentales. Su belleza, su rareza, su intensidad de color y sus propiedades mecánicas han hecho que fueran gemas muy preciadas desde la Antigüedad y que sigan utilizándose en la joyería actual. En este volumen los especialistas pueden consultar los datos científicos más recientes sobre un tipo de objetos muy común en la cultura de las tribus indígenas norteamericanas. Sin embargo, dada la diversidad de los puntos de vista que se barajan resulta muy interesante para cualquier conservador, restaurador, historiador, artista o artesano que quiera ampliar sus conocimientos en torno a estos objetos ligados al patrimonio inmaterial de forma indiscutible en sus orígenes, debido a su doble carácter ritual y ornamental.

Una parte del libro se centra en la ciencia para la conservación de los mosaicos de turquesa considerados como objetos patrimoniales albergados en museos. Los distintos trabajos suponen las investigaciones científicas más relevantes de los especialistas en este tema. Algunos de ellos estudian las propiedades comparadas de las turquesas identificadas con la gema en bruto, para determinar su procedencia. Otros se interesan por la aproximación a la tecnología requerida en el ámbito prehispánico para la manufactura de este tipo de bienes culturales. Para subrayar su 
importancia cabe indicar que entre ellos se estudian las piezas de la colección del Museo Británico, el mosaico del templo Mayor de Tenochtitlan y el de Tula.

Una segunda parte del volumen se centra en la cultura que envuelve a los objetos realizados con turquesas y el estudio de las colecciones existentes. Muchos de estos estudios se centran en las colecciones de objetos prehispánicos, hechos con turquesas, existentes en diversos museos europeos y americanos. En varios capítulos de este apartado se describe la morfología y el simbolismo de los mosaicos ornamentales que configuraban máscaras, recipientes, collares y otros aderezos adornados con turquesas. Esta parte incluye también estudios comparativos del material arqueológico con la moderna joyería surgida a partir del siglo XIX, para distinguir la inspiración en las raíces prehispánicas de las innovaciones actuales. Por último, no podía faltar un apunte de la minería antigua y actual.

Marisa Gómez González Instituto del Patrimonio Cultural de España 


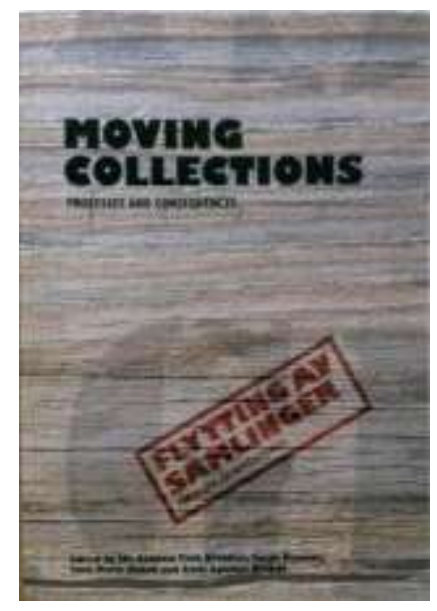

\section{Moving Collections. Processes and Consequences Flytting av samlinger. Prosesser og Konsekvenser}

Editado por Ida Antonia Tank Bronken, Susan Braovac, Tone Marie Oistad and Anne Apalnes Ørnhøi.

Publicado por Archetype Publications Ltd in association with NKF-N (Nordisk Konservator Forbuind-Norge). London, 2012.

220 páginas, $297 \times 210 \mathrm{~mm}$.

ISBN: 978-1-904982-84-5

Este texto recoge las contribuciones ( 24 comunicaciones y 8 posters) presentadas en la conferencia "Planing to move? Processes and consecuences for collections, objects and society", organizada por la sección Noruega de la Nordic Conservator Association, del grupo Nórdico del IIC, que tuvo lugar entre los días 15 y 17 de octubre de 2012, en Oslo.

Dado el lugar de celebración del evento y que la organización corrió a cargo de la sección Noruega del IIC, poco más de la mitad de las comunicaciones son en inglés, mientras que el resto están escritas en noruego, con abstacts en inglés (algunos muy reducidos), lo que en la práctica limita nuestra capacidad de comprensión.

El objeto de la conferencia fue el transporte de objetos y obras de arte. Esta es una de las tareas que está adquiriendo mayor importancia en la vida de los museos e instituciones que albergan colecciones. Continuamente se mueven piezas para renovar y mejorar las formas de gestionar su exhibición, almacenamiento, estudio o tratamiento. Pero el interés sobre este tema es de máxima actualidad dada la necesidad que tienen algunas instituciones de planificar en la próxima década el traslado de una parte importante o el total de sus colecciones.

Uno de los intereses centrales de la reunión era conocer experiencias actuales que describieran tanto los retos como las soluciones aplicadas en campos como la logística, los estándares de embalaje o los sistemas de control. Se presentaron ejemplos concretos de trabajos de investigación y casos prácticos que cubren el movimiento de los más variados objetos, a todas las escalas.

El continuo desarrollo de los museos y el crecimiento de las colecciones implican la búsqueda de soluciones temporales o definitivas para el almacenamiento de las nuevas obras, para la adaptación a los nuevos modelos expositivos o a los nuevos servicios requeridos. Esto obliga a planificar movimientos complejos por la naturaleza de las piezas involucradas, su número y dimensiones. Obliga a trabajar conjuntamente y a coordinar equipos compuestos por especialistas de distintas disciplinas y también, en muchos casos, a tomar decisiones en cierto modo pragmáticas, asumiendo los riesgos y las limitaciones que impone la realidad. 
Las comunicaciones presentan una gama muy variada de necesidades y enfoques, en función de las dimensiones de los museos, de la naturaleza de sus colecciones y de las características y de las posibilidades de cada institución. En este sentido hay referencias a traslados masivos de obras como en el caso del Museo Nacional de Arte, Arquitectura y Diseño de Oslo; del Museo de Bellas Artes de Boston; del Museo Victoria and Albert de Londres; del Museo de Arte Popular de Lisboa o del Museo Nacional de Islandia en Reikiavik. También se describen movimientos de colecciones más pequeñas como la del Museo Munch de Oslo; del Museo de la Cultura Mundial de Gotemburgo; la colección de registros sonoros de la Universidad de Kansas o la sección de fotografía del Museo de la Ciudad de Estocolmo. A otra escala se presentan los traslados del barco vikingo más grande del mundo, durante una exposición itinerante o el desmontaje, tratamiento y la recolocación de una instalación del artista finlandés Antero Ruotsalainen, por ejemplo.

Salvo tres comunicaciones que desarrollan investigaciones sobre factores de deterioro o estándares de manipulación y transporte, en general todos los trabajos presentados tratan casos particulares. En unos se pone el acento en la unificación de servicios de almacenamiento, sistemas registro, gestión y control, entre varios museos de pequeñas dimensiones. En otros ejemplos se centran en resolver retos específicos como el movimiento y la reubicación de obras durante los trabajos de ampliación de un museo o la adaptación de edificios industriales para el almacenamiento y exhibición de objetos.

Precisamente hay que destacar, como uno de los puntos fuertes de esta publicación, la abundancia de casos prácticos diferentes, pero marcando siempre la importancia de la calidad del trabajo llevado a cabo, tanto en la planificación como en la realización práctica de los traslados, ya se trate del movimiento de un elemento aislado como de una colección completa.

En el lado negativo, hay que mencionar que una parte importante de los textos están escritos en noruego. Esta es una cuestión de cierta importancia que pone en evidencia la cada vez mayor necesidad de publicar en un idioma de uso internacional, si queremos que la información llegue de forma global a la comunidad profesional y científica.

Emilio Ruiz de Arcaute Diputación Foral de Álava 

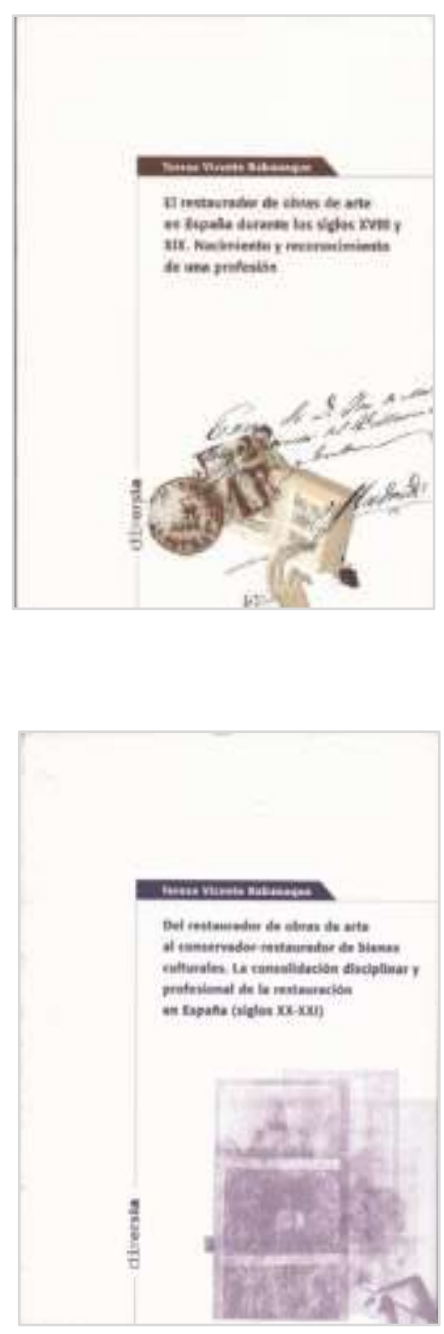

\section{El restaurador de obras de arte en España durante los siglos XVIII y $X I X$. Nacimiento de una profesión}

Teresa Vicente Rabanaque

Valencia, Universitat Politècnica de València, 2012. 300 páginas, $207 \times 145 \mathrm{~mm}$.

ISBN: 978-84-8363-965-8
Del restaurador de obras de arte al conservador-restaurador de bienes culturales. La consolidación disciplinar y profesional de la restauración en España (siglos XX-XXI)

\section{Teresa Vicente Rabanaque}

Valencia, Universitat Politècnica de València, 2013. 317 páginas, $207 \times 145 \mathrm{~mm}$.

ISBN: 978-84-9048-008-3

De esta ambiciosa investigación, desarrollada por Teresa Vicente Rabanaque para su doctorado en la Universidad Politécnica de Valencia, podían haberse derivado no una sino dos o más tesis doctorales. En efecto, es un reto admirable, no exento de riesgos, el que se propone la autora: analizar la figura del restaurador desde el siglo XVIII, momento en que se empieza a perfilar la restauración de obras de arte como una disciplina diferenciada, hasta el presente actual. Así, el resultado se ha dividido en dos publicaciones independientes, una primera aparecida en 2012 y dedicada, como señala el título, al nacimiento y reconocimiento de una profesión (siglos XVIII y XIX) y la segunda, de 2013, a la consolidación disciplinar y profesional en el siglo pasado y el actual.

El trabajo de Teresa Vicente Rabanaque tiene dos importantes antecedentes en María Dolores Ruíz de Lacanal y Ana Macarrón, cuyas obras son referencia obligada para cualquier estudio histórico de la conservación-restauración en España. Sin embargo, la autora resalta en la introducción de ambos libros cómo su principal objetivo ha sido estudiar la evolución histórica de la conservación y restauración fijando su atención no en los propios objetos culturales sino en el restaurador como sujeto, desde una óptica sociocultural y antropológica. Es indudable que el conocimiento de la realidad social y cultural de los restauradores nos aporta claves fundamentales para comprender la 
importancia que la sociedad concede al patrimonio cultural en cada momento histórico. Era necesario, pues, este punto de vista para abordar la historia de la restauración en España.

Para obtener la información combina dos métodos diferentes: el estudio de las fuentes documentales y la entrevista a profesionales de diferentes ámbitos, más común el primero en la investigación histórica y el segundo en las ciencias sociales. El resultado es un extraordinario caudal de datos históricos, muchos de ellos inéditos, producto de su trabajo en archivos institucionales que se complementan con los comentarios personales de los entrevistados. Si bien se limita a solo tres ciudades, Madrid, Barcelona y Sevilla (Valencia lo descarta por haber sido ya estudiada recientemente), es cierto que son las más significativas por acoger los avances producidos en este campo.

En el primer libro, tras una revisión del contexto europeo, describe el marco histórico del siglo XVIII español, con el nacimiento de la disciplina en nuestro país alrededor de la Corte y las intervenciones en las colecciones reales a raíz del incendio del Alcázar madrileño, para desarrollar el siglo XIX con sus múltiples facetas, desde la aparición de los primeros tratados españoles de restauración de obras de arte (Poleró y Toledo, de la Roca y Delgado) a otras menos conocidas pero de enorme interés: el papel de la Academia de Bellas Artes como instancias supervisoras, del Museo del Prado y de la Trinidad como canteras de formación de restauradores y de afirmación profesional, las primeras oposiciones, el papel no menos importante de las Comisiones Provinciales de Monumentos, sin descuidar los perfiles biográficos de las figuras más sobresalientes en las diferentes instituciones y en las tres ciudades estudiadas.

El segundo libro aborda un siglo XX quizá menos conocido por no haber sido aún apenas abordado con un espíritu analítico, en el que encontramos los más inmediatos antecedentes de nuestra situación actual: las normativas y reglamentos que van a empezar a regular la profesión y que van a ir enmarcando su evolución; los concursos y oposiciones para museos; las reivindicaciones laborales de los restauradores del Prado que anuncian las dificultades arrastradas por esta profesión para consolidar su entidad profesional; la creación de la Junta de Conservación de Obras de Arte en 1924, primer servicio nacional para la conservación y restauración del patrimonio; la situación crítica de la Guerra Civil y las operaciones de salvamento puestas en marcha en las distintas ciudades. Por último, la segunda mitad del siglo, iniciada con una postguerra que acusa la enorme falta de personal, lo que desemboca, con el despegue económico de los años 60 y la apertura al exterior, en la creación de las primeras cátedras de restauración en algunas Facultades de Bellas Artes por un lado, y por otro en la creación del ICROA, primera institución nacional dedicada a la intervención, a la investigación y a la formación de restauradores con sus propios laboratorios científicos.

Como sugiere María Dolores Ruiz de Lacanal en su prólogo al segundo libro, en esta obra "se exponen multitud de piezas de la memoria de la profesión". Estas piezas no tienen una intención totalizadora, en efecto, como bien reconoce la autora, pero el trabajo constituye un compendio perfectamente documentado del pasado de nuestra profesión que nos ayuda a explicarnos cómo se ha ido modelando hasta el momento actual y en el que cada capítulo nos invita a continuar abriendo nuevas vías de investigación. El trabajo realizado por Teresa Vicente Rabanaque es un gran paso que esperamos estimule a nuevos investigadores a seguir reconstruyendo la historia de la conservación y restauración de bienes culturales en España.

Rocío Bruquetas Galán Instituto del Patrimonio Cultural de España 


\section{www.revista.ge-ilc.com}

Edición digital del GEIIC 